\title{
COMMUNICATION AND THE CHANGING ROLES OF PUBLIC ART MUSEUMS: LESSONS FOR MUSEUM PROFESSIONALS
}

\author{
By \\ Wendy Quinlan-Gagnon, B.A., M.A., M.P.A. \\ A thesis submitted to the Faculty of Graduate Studies and Research in partial \\ fulfillment of the requirements for the degree of Doctor of Philosophy
}

School of Journalism and Communication

Carleton University

Ottawa, Ontario

April 2011

(c) Wendy Quinlan-Gagnon 
Library and Archives

Canada

Published Heritage

Branch

395 Wellington Street

Ottawa ON K1A ON4

Canada
Bibliothèque et

Archives Canada

Direction du

Patrimoine de l'édition

395 , rue Wellington

Ottawa ON K1A ON4

Canada
Your file Votre référence
ISBN: 978-0-494-81578-6
Our file Notre référence
ISBN: $978-0-494-81578-6$
NOTICE:

The author has granted a nonexclusive license allowing Library and Archives Canada to reproduce, publish, archive, preserve, conserve, communicate to the public by telecommunication or on the Internet, loan, distribute and sell theses worldwide, for commercial or noncommercial purposes, in microform, paper, electronic and/or any other formats.

The author retains copyright ownership and moral rights in this thesis. Neither the thesis nor substantial extracts from it may be printed or otherwise reproduced without the author's permission.

\section{AVIS:}

L'auteur a accordé une licence non exclusive permettant à la Bibliothèque et Archives Canada de reproduire, publier, archiver, sauvegarder, conserver, transmettre au public par télécommunication ou par l'Internet, prêter, distribuer et vendre des thèses partout dans le monde, à des fins commerciales ou autres, sur support microforme, papier, électronique et/ou autres formats.

L'auteur conserve la propriété du droit d'auteur et des droits moraux qui protège cette thèse. $\mathrm{Ni}$ la thèse ni des extraits substantiels de celle-ci ne doivent être imprimés ou autrement reproduits sans son autorisation.
In compliance with the Canadian Privacy Act some supporting forms may have been removed from this thesis.

While these forms may be included in the document page count, their removal does not represent any loss of content from the thesis.
Conformément à la loi canadienne sur la protection de la vie privée, quelques formulaires secondaires ont été enlevés de cette thèse.

Bien que ces formulaires aient inclus dans la pagination, il n'y aura aucun contenu manquant.

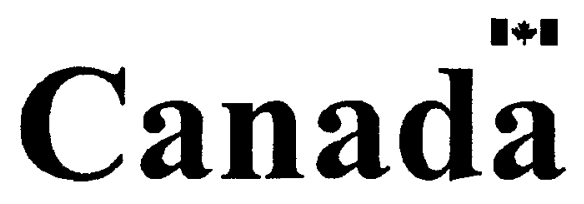




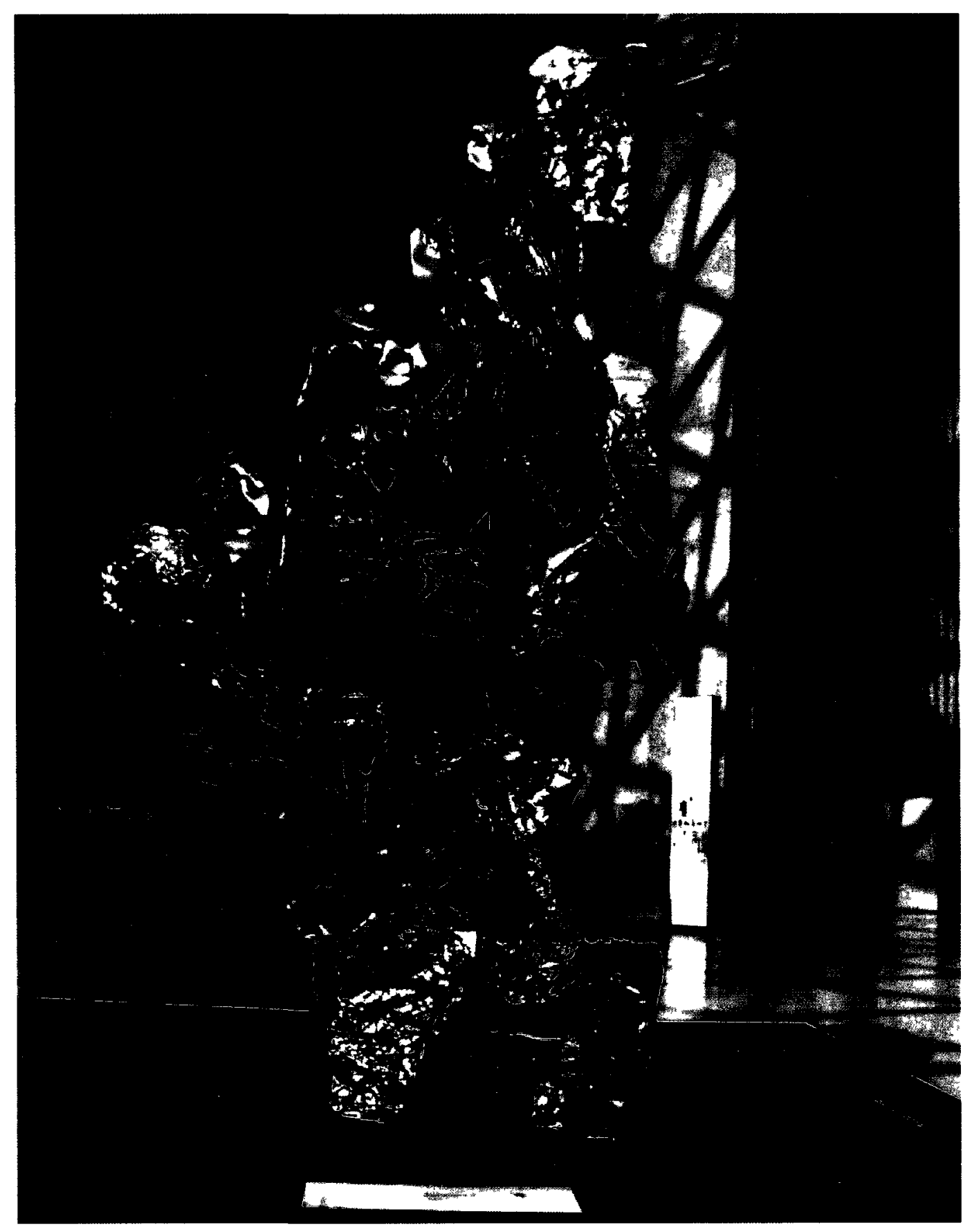

Shops and Sculptures: Interesting Juxtapositions at the British Museum

(Photo: Benjamin Earle, 2008) 


\begin{abstract}
This thesis examines the changing roles of public art museums over the last 40 years. Using the National Gallery of Canada, the Boston Museum of Fine Arts, the Museum of Modern Art in New York and Tate Modern in London as casestudies, I examine these organizations in an attempt to show that despite pressures to become more inclusive, art museums, unlike some cultural institutions, have retained an air of elitism. One reason for choosing four such disparate art museums in three different socio-political environments is to determine if there is any commonality in their modus operandi, in order to ascertain if we might say that, in general, public art museums are still complicit in constructing many exclusionary discourses-even as they claim, in their mission statements or mandates, to reach out to more diverse audiences.

Art museums, as we know, have long been the purview of the elite and yet I believe, with Martha Nussbaum, Jeffery Deitch, Chantal Mouffe and others, that exposure to the arts is an enriching experience from which we can all benefit. With more and more cut-backs in humanities teaching in our schools and universities, I believe that cultural institutions such as art museums must try to reach out to more and more diverse publics.

To help thresh out my thesis, I take the perspective that art museums, in and of themselves, are "means of communication." To explore this idea, I analyse not only the programs, policies and direct marketing strategies of the four case-study museums I have selected, but also their buildings, interior ambiance, restaurants, cafés, bars and shops. I study their member/donor benefits and I look at the kinds of exhibitions they host and the different ways in which they hang their art. Finally, I review several of their publications and discuss the design, content and usability of their websites. My research supports my thesis that while art museums have indeed changed over the last 40 years, they continue to construct hidden barriers that keep some potential publics away.
\end{abstract}




\section{Acknowledgments}

I would like to thank my supervisor, Professor Michèle Martin and my committee members, Professor Miranda Brady and Professor Ira Wagman, for ongoing help and encouragement; Dr. Astrid Berrier and Dr. Francis Slaney for enlightened comments and suggestions; the membership secretaries at the National Gallery of Canada, the Boston Museum of Fine Arts and the Museum of Modern Art in New York for completing my survey questionnaire; the membership secretary at Tate Modern in London for pointing me to its website; my sons, Mark and Simon Earle, my daughters-in-law, Rhonda Evraire (Mark) and Christine Earle (Simon), my beautiful grandchildren, Benjamin and Jessica Earle (Simon \& Christine) and William and Christopher Earle (Mark \& Rhonda); my "other son" Steven Earle and his family, Joanne Laprise and little Jacob, and my step-son, Will Roney, for their ongoing support, love and inspiration; my friends Sara Bannerman, Kerstin Bjarbo, Nadja Corkum, Ginette Danis, Imtyaz Mohamed, Lynda Noppe, Vera Pachner, Audrey Paton, Sue Sheane and Dorothy Wood for their encouragement, especially during the tough times; my former managers, Nicole Gionet at Newbridge Networks and Alcatel (now Alcatel-Lucent) and Katherine Parker at Agriculture and Agri-Food Canada, for providing both time and financial support; Benjamin Earle and Imtyaz Mohamed for supplying photographs for my dissertation; Nadja Corkum for proof-reading my manuscript; Sue Sheane for reviewing my bibliography; Dr. Sara Bannerman and Blayne Haggart for attending my defence; and Michelle Bateman from the MCOMM office at Carleton University for timely reminders and other invaluable administrative support. 


\section{Table of Contents}

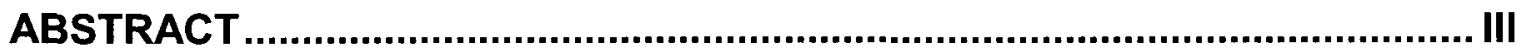

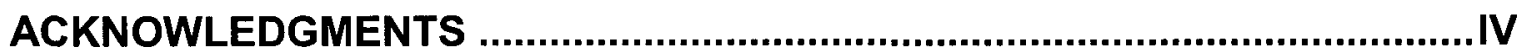

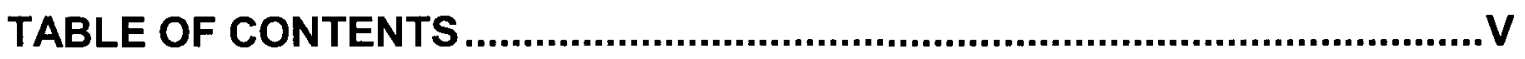

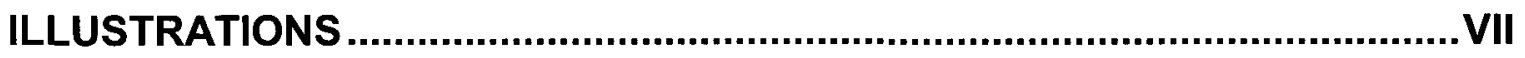

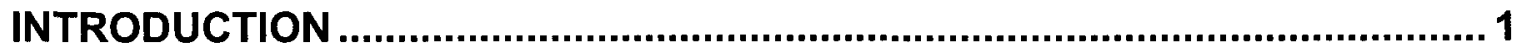

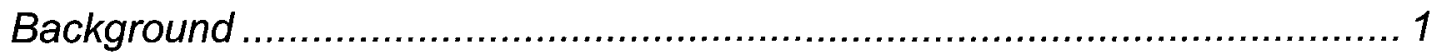

CHAPTER ONE - THEORY AND METHODOLOGY .................................... 13

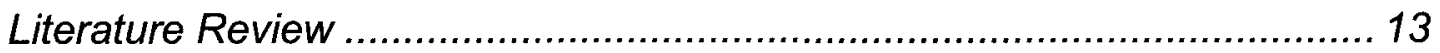

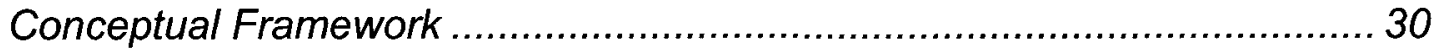

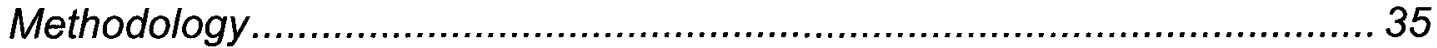

CHAPTER TWO - FROM CLASS CULTURE TO MASS CULTURE: SOCIAL CHANGES, GOVERNMENT POLICIES AND THE DEMOCRATIZATION OF PUBLIC ART MUSEUMS .......................................................................... 46

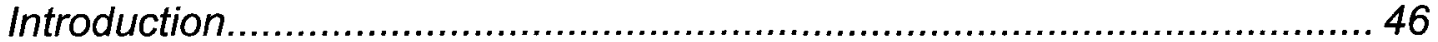

A Short History of Art Museums in Western Europe and North America .... 48 From Class Culture to Mass Culture: Social Change and the Growth of the Public Art Museum since the Late Eighteenth Century ............................6 63 Government Policies, Arts Funding and the Democratization of Public Art Museums at the End of the Twentieth Century...................................... 72

CHAPTER THREE - ATTRACTING AND KEEPING DIVERSE PUBLICS ....... 84

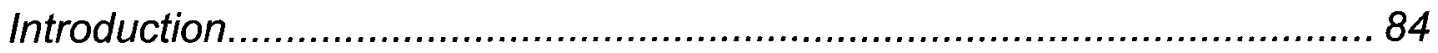

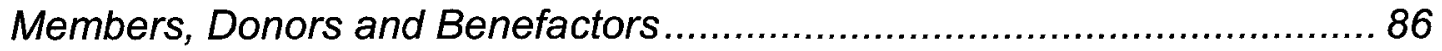

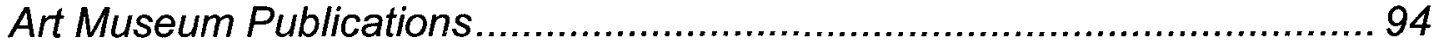

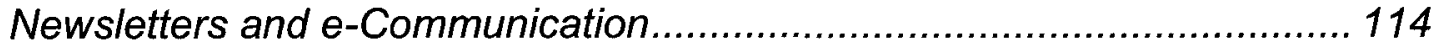

Lectures, Films and Music............................................................. 115

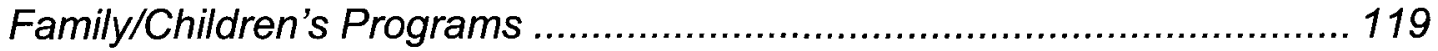

Education and Community Outreach................................................... 122

Summer Blockbusters and Other Popular Events ................................ 127

CHAPTER FOUR - ARCHITECTURE AND AMBIANCE, CAFÉS, BARS, RESTAURANTS AND SHOPS .............................................................. 130

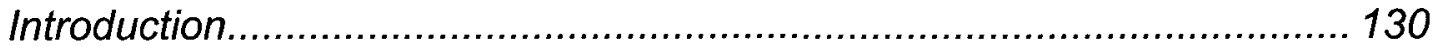

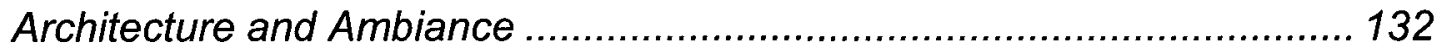

CHAPTER FIVE - ART MUSEUMS ONLINE: BUILDING CULTURAL CAPITAL USING INTERACTIVE WEBSITES............................................................. 163

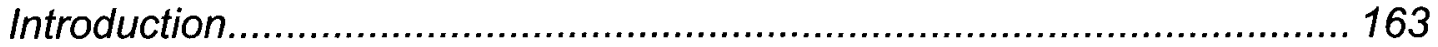




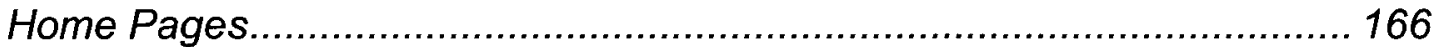

Embedded Information-Something for Everyone? ............................. 175

Images of People in Art Museums........................................................ 184

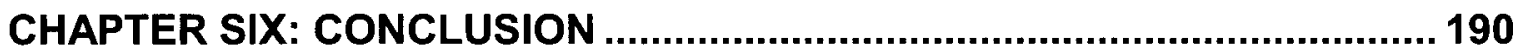

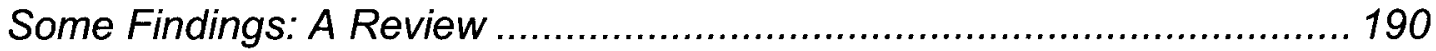

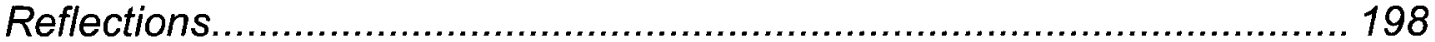

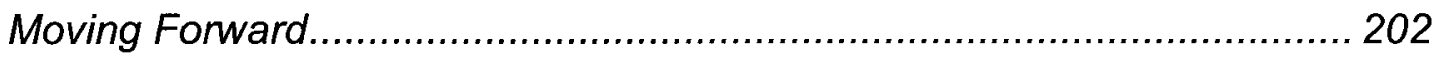

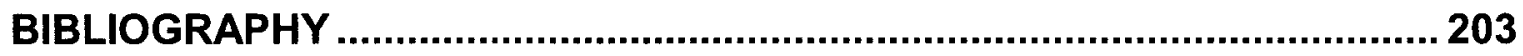

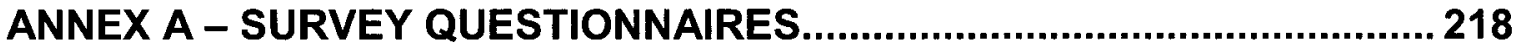

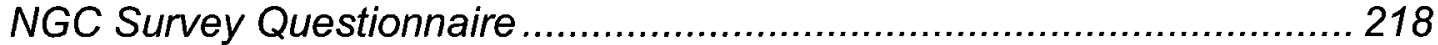

MFA Survey Questionnaire ............................................................. 219

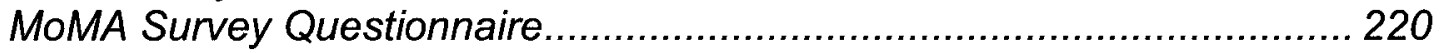

Tate Modern Survey Questionnaire * ............................................... 221

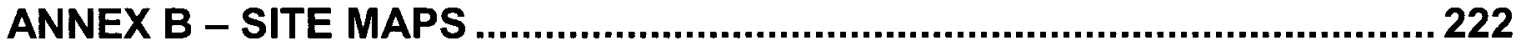

National Gallery of Canada Site Map ................................................ 222

Boston Museum of Fine Arts Site Map .............................................. 224

The Museum of Modern Art Site Map.................................................. 226

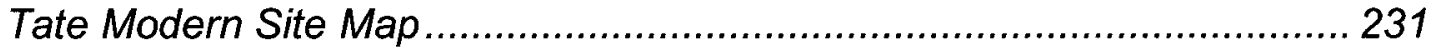

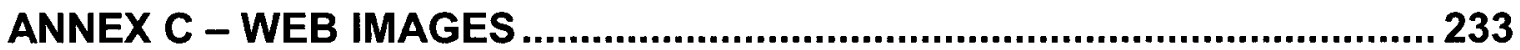

Images from the Young Tate Website: Reaching Out to Teens ............... 233

Images from the Young Tate Website: Reaching Out to Teens ............... 234

Teen Programs at the MoMA .......................................................... 235

Teens at the MFA: College ............................................................ 236

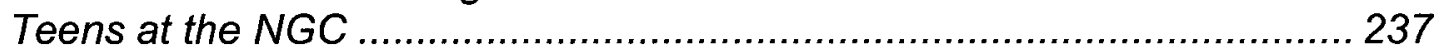




\section{Illustrations}

Shops and Sculptures: Interesting Juxtapositions at the British ii

Museum

Hradcany, the Prague Castle $\quad 49$

Palais Royale, Paris 51

The Hermitage Museum, St Petersburg 52

Le Palais du Louvre $\quad 54$

The Belvedere Palace, Vienna $\quad 55$

Tate Britain, London $\quad 56$

Tate Modern (1), London $\quad 57$

The Metropolitan Museum, New York 58

The Museum of Modern Art, New York 60

The Canadian Academy of Arts $\quad 61$

Vernissage Magazine Covers $\quad 99$

Tate ETC Magazine Covers $\quad 101$

MoMA Magazine Covers $\quad 102$

Preview Magazine Covers $\quad 103$

Exhibition Catalogues $\quad 113$

National Gallery of Canada, Ottawa 132

NGC Colonnade Ramp 133

Tate Modern (2) London $\quad 137$

Tate Modern Ramp Leading to the Turbine Hall 139

Tate Modern Turbine Hall 140

Small Children at Tate Modern on Opening Day 141

Young Teens Enjoying Tate Modern 141

Visitors Relaxing Inside and Outside Tate Modern $\quad 141$

Viewing Rooms at Tate Modern 143

MoMA Entrance Outside and Inside $\quad 145$

MoMA the Viewing Galleries $\quad 146$

Museum of Fine Arts, Boston 148

Viewing Gallery and Covered Windows $\quad 149$

Two Views of the I.M. Pei Galleria, MFA, Boston 150

Bravo Restaurant, MFA, Boston 156

The MoMA Restaurant, the Modern 157

$\begin{array}{ll}\text { Tate Modern Restaurant } & 157\end{array}$

NGC Café l'Entrée, Ottawa 158

The Galleria, MFA, Boston $\quad 159$

Items from the MoMA Design Shop 161

Web Screen Shots (Chapter Five) 168-188

More Tate Modern Web Images (Annex C) 233

More MoMA Web Images (Annex C) 234

More MFA Web Images (Annex C) 235

More NGC Web Images (Annex C) 236 


\section{Introduction}

[I]f the love of art is the clear mark of the chosen, separating, by a superior and insurmountable barrier, those who are touched by it from those who have not received this grace, it is understandable that in the tiniest details of their morphology and their organization, museums betray their true function, which is to reinforce for some the feeling of belonging and for others the feeling of exclusion.

(Bourdieu, Darbel \& Schnapper, "Conclusion to the Love of Art," in Carbonell, 2004)

In recent years there has been an increasing emphasis on dismantling barriers to access [to public art museums] and on providing services for a much broader range of people. In return for public funding we are being called upon to demonstrate that our services represent good value, are relevant to the needs of users and are developed in partnership with them. Museums and galleries are also looking at the perceptions of nonusers, targeting new audiences and realising the benefits of inclusive practice for all concerned.

(Caroline Lang, Foreword to Including Museums, 1993)

\section{Background}

My purpose in this dissertation is to investigate the tensions between tradition and innovation, elitism and populism at four distinctly different public art museums ${ }^{1}$ as they move into the 21 st century: the National Gallery of Canada (NGC), the Boston Museum of Fine Arts (MFA), the Museum of Modern Art in New York (MoMA) and Tate Modern in London. I argue, for example, that as less and less public money becomes available to support cultural institutions, these museums walk a fine line between reaching out to mass audiences and maintaining enough of their original purpose (education, scholarship and the display of fine art in a dignified environment) to continue attracting the privileged

\footnotetext{
${ }^{1}$ By public art museum, I mean any art museum or art gallery open to the general public which may or may not be (at least partially) funded with public money and where people go to view art rather than to buy it.
} 
individuals and corporate sponsors ${ }^{2}$ who can, and do, help to support them both intellectually and financially. I suggest, however, that despite many innovations introduced to attract the general public (interactive displays, audio guides, snack bars, vending machines, websites and shops) these museums are still heavily focused on providing exclusive environments for exclusive visitors. To that end, I argue, that while art museums have indeed changed over the last 40 years, as "means of communication," they continue to construct hidden barriers that keep many potential publics away. Furthermore, my research shows that they do so through a variety of covert discursive practices - even as they overtly target those very audiences that these barriers deter.

The four art museums I have chosen to examine are all museums I know and frequent. Furthermore, they are all museums which claim, in their mission statements or mandates, to be reaching out to more and more diverse publics. The National Gallery of Canada, for example, speaks of reaching out to "all Canadians" (National Gallery Website, 2011); the Tate talks of developing new audiences and deepening relationships with current audiences (Tate Website 2011); MoMA aims to serve "diverse local, national, and international audiences," (MoMA Website, 2011); and the MFA pronounces its "obligations to the people of Boston and New England, across the nation and abroad" to celebrate "diverse cultures" and welcome "new and broader constituencies" (MFA Website, 2011). To varying degrees they have all received public, government or private

\footnotetext{
${ }^{2}$ This thesis does not examine the role of corporate sponsors.
} 
directives to become more inclusive. For this reason, I believe that they are good examples against which to test my thesis.

My reason for choosing four such disparate art museums in three such different socio-political environments is to determine if there is any commonality in their modus operandi, especially in the way they are responding to pressures to attract wider audiences. My objective is to ascertain if we might say that "in general" public art museums are still complicit in constructing and helping to maintain social boundaries and the social/political status quo in their concomitant societies or whether, as Jeffery Deitch has suggested, we can find spaces within these institutions to challenge and change the hegemonic powers that have always been associated with them-that is, to find spaces where "radical democratic alternatives to neoliberalism could...be imagined and cultivated," and where people from all walks of life can enjoy the benefits that art can bring them (Deitch, Artforum, Summer, 2010).

For Deitch, art must never be just for the "rarefied elite" but for as many different audiences as possible. Art, he says, can be a progressive social force and, by becoming more inclusive and engaging new publics, art museums can help to build communities of art lovers who in turn may become better citizens. ${ }^{3}$ Deitch truly believes that art can enhance people's lives. "People can look at a work of art, or listen to a band," he says, "and their consciousness can be changed" (ibid.).

\footnotetext{
${ }^{3}$ At the same time, Deitch recognizes the importance of keeping traditional patrons and philanthropists engaged and interested in order to elicit their financial and other support.
} 
Writing in the same issue of Artforum, Chantal Mouffe considers art museums within the context of radical democratic politics. Arguing against such political theorists as Hardt and Negri who would do away with these institutions altogether (see Enwezor in Artforum, October, 2009), Mouffe believes, like Deitch, that the hegemonic forces that have constituted the art museum in the past can, and should, be challenged in such a way as to bring about new and better ways of imagining these important spaces (Mouffe, Artforum, op cit.). The art museum, she says, could become a place where counterhegemonic practices can contribute to undermining bourgeois dominance and the neoliberal market hegemony (ibid). Mouffe cites the Museu d'Art Contemporani de Barcelona which, under the direction of Manuel Borja-Villel, created a new model that saw the art museum reaching out to artists "typically ignored by the dominant discourses on artistic modernity" and participating in community activities that brought together citizens from many different walks of life to discuss not only art but also topics such as "precarious labor, borders and migrations, gentrification, new media, and emacipatory practices" (Mouffe, ibid). I interpret this to say that by opening up the art museum to new and different artists/audiences/topics of discussion, Borja-Villel has made the Museu d'Art Contemporani de Barcelona more inclusive and more democratic, giving it a significant role in reclaiming civil society from the throes of neoliberal politics.

Both Kathy Halbreich and Martha Nussbaum emphasize the importance of art and art museum spaces for challenging our ways of thinking. As a culture, Halbreich says, "we are not really interested in ambivalence or ambiguity...we 
give no reward to intelligent failure" (Artforum, Summer 2010). Artists, she argues, and by default the art they produce, force us to confront these things and they "shape us more than we think" (ibid.). Inherent in art, she says, is a search for meaning, but great objects do not often reveal their secrets. Art challenges us as individuals and an art museum can provide an "unusually capricious umbrella for personal and communal investigation" (ibid.).

For Nussbaum, the arts are essential for "producing citizens who can think for themselves, criticize tradition and understand the significance of another person's sufferings and achievements" (Nussbaum, 2010, p.13). Nussbaum sees the demise in humanities teaching-exposure to art, literature, music, etc. at all levels of the education system and beyond -as the direct result of our pursuit of profit in the global marketplace and warns that we will never solve our widespread economic, environmental and social problems with factual knowledge alone. "Science, social science and economics", she argues, can only be practiced at their best when "infused" with what she calls "the spirit of the humanities: by searching critical thought, daring imagination, empathetic understanding of human experiences of many different kinds, and understanding of the complexity of the world we live in-a world in which people face one another across gulfs of geography, language and nationality" (ibid.). Nussbaum draws on Socrates as well as Tagore, Thucydides, Rousseau, Dewey and British paediatrician/psychoanalyst D.W. Winnicott to make her point. All of these important thinkers considered participation in the arts to be central to human development. 
My own interest in this topic stems from both my love of art and my belief, along with Deitch, Mouffe, Halbreich, Nussbaum and others, not only that exposure to the arts in general, and to fine art in particular, can be an enriching experience from which we can all gain personally (art gives us pleasure), but also that art, and therefore public art museums as well as other cultural institutions, have important roles to play in the kinds of societies we create and the kinds of citizens we become (art makes us thoughtful). For me, it is important that public art museums ensure that all citizens have access to the kinds of aesthetic and intellectual experience that art can give us. One purpose of my research has been to highlight some of the changes that have taken place in public art museums over the last 40 years; another has been to show that, despite those changes, these institutions, because of the hidden messages they send, are still tinged with an elitism that keeps many potential publics away.

To help thresh out my thesis, I take the perspective that art museums, in and of themselves, are "means of communication" that generate many different discourses. Here I use the concept "means of communication" as articulated by Siegelaub in the introduction to Communication and Class Struggle: Vol. 1 Capitalism, Imperialism, (Siegelaub and Mattelart, 1979). Siegelaub claims that "means of communication" consist not only of the instruments of communication (speech, writing, radio, television, books, magazines, etc.) but also of the human interaction that takes place with those instruments of communication (Siegelaub, 1979, p. 12). In Communication and Class Struggle: Vol 2, Liberation, Socialism, Siegelaub argues that "means of communication" consist of "real links between 
real people" (Siegelaub and Mattelart, 1983, pp. $11-16$ ). This concept is useful because it allows me to show how institutions such as art museums, in their entirety, exude both overt and covert messages that affect the way people relate to them.

To uncover some of the myths and ideologies that pervade the art museum environment, my dissertation examines how the four art museums I have selected speak to both elite ${ }^{4}$ patrons and mass audiences, not only through the direct images they project but also through the hidden messages behind those images. When I speak of images, however, I am not talking of the art and I do not just mean pictures. I am referring to the many different components that constitute the art museum experience.

For example, I analyse not only the programs, policies and direct marketing strategies of the four case-study museums, but also their buildings, interior ambiance, restaurants, cafés, bars and shops. I study their member/donor benefits and I look at the kinds of exhibitions they host and the different ways in which they hang their art. Finally, I review several of their publications and discuss the design, content and usability of their websites. Borrowing some ideas from both Roland Barthes' Mythologies and The Semiotic Challenge and Maria Sturken and Lisa Cartwright's Practices of Looking, I

\footnotetext{
${ }^{4}$ By elite(s) I mean the dominant classes (people with money, academics, other intellectuals and the well-educated middle classes) who help to shape our society. Bourdieu makes a distinction between those with cultural capital and those with economic capital. He says that those with economic capital may not always have the cultural capital to match their means (Bourdieu, 2002, p. 287). Nonetheless, they often support art museums and other "high culture" institutions for the prestige it can bring them (see below for a discussion on Bourdieu)
} 
explore how meanings are produced and how or what messages are disseminated-and to whom.

Barthes shows us how to read signs and images to discover the myths (hidden sub-texts) that he says exist behind all denotation - that is "to study that mysterious operation by which any message may be impregnated with a secondary meaning, a meaning that is diffuse, generally ideological, and which is known as the "connoted [sic] meaning" ${ }^{5}$ (Barthes, 1994. p. 159). At the same time, Sturken and Cartwright argue that social relationships are negotiated through looking. Looking, they say, is a practice much like speaking. It involves learning to interpret, and most of all it is about power (Sturken and Cartwright, 2001, p.20). "Looking" is a large part of what people do in art museums and plays of power are much in evidence. If we are to believe Bourdieu that "the love of art is the clear mark of the chosen" and that art museums welcome some visitors while erecting hidden barriers in front of others (Bourdieu, A. Darbel \& D. Schnapper, in Carbonell, 2004, p. 434), then for some people, at least, the art museum experience is very much about exclusion.

Questions such as "What is art?" and "What is the role of the art museum in society?" have engaged the minds of critics and the viewing public alike for many centuries. For the longest time "true or real" art was associated with the elite, while the "common" people were thought to understand and enjoy only the more vulgar forms of entertainment (Bourdieu, 1984). Serious art was the purview of monarchs or the aristocracy and was kept hidden away in palaces and

\footnotetext{
${ }^{5}$ Italics in the original
} 
castles, far from the eyes of the "madding crowd." Publicly or privately funded art museums as we know them today were first introduced with the expansion of capitalism during the $18^{\text {th }}$ century at a time when the concept of a bourgeois public and a bourgeois public sphere were coming into their own (Duncan, 1995, p.3).

Changes in thinking around civil society at this time brought about changes in the way people were governed-moving away from a top-down police state approach to a state of governmentality whereby individual citizens, exposed to new kinds of power/knowledge modalities, helped to govern themselves. ${ }^{6}$ In a lecture presented to the Collège de France in February 1978, Michel Foucault defined governmentality as the principal form of governance in the modern episteme. ${ }^{7}$ Foucault argued that whereas earlier governments were concerned with protecting the absolute power of the sovereign and the sovereign's right to rule, later governments were (and are) more concerned with the control of their populations (Foucault, 2000, pp. 201-222). And while earlier governments had foregrounded the law as a means of keeping order, modern governments began to rely on more indirect methods such as persuasion-seeing the population not only as "subject of needs and aspirations," but also as "object in the hands of the government," aware, "vis-à-vis that government, of what it wants, but ignorant of what was being done to it" (Foucault, ibid.). Individuals within a system of governmentality become loyal citizens by learning how to conduct themselves

\footnotetext{
${ }^{6}$ By this I mean that citizens learned and practiced the protocols of civil society without those protocols being overtly imposed upon them from the outside.

"Foucault used the term "episteme" to mean periods or epochs of like-thinking.
} 
within that society. Institutions such as the family, the school, the legal system and the church—what Althusser (1978) called "Ideological State Apparatuses"contribute to this learning. Bennett argues that museums and other cultural institutions are complicit in this construction of the self-governing citizen (Bennett, 2002, p.7).

In fact, as collections of art and other cultural artifacts were removed from the palaces and castles of reigning sovereigns to become the property of democratic governments, museums were overtly promoted as institutions of cultural and social learning. In England, for example, social reformers such as Thomas Colquhoun (1806), James Silk Buckingham (1849), Benjamin Ward Richardson (1876) and Thomas Greenwood (1888) all advocated for public museums and other cultural spaces that would serve as instruments of government to help tame the unwashed masses (Bennett, ibid, pp. 17-58). ${ }^{8}$ It was believed that by opening up museums (including art museums) to the "lower" classes all manner of socially deviant behaviours could be eliminated. Workingclass men, in particular, it was thought, would begin to emulate middle-class codes of conduct and in turn influence their wives and children to do the same (Bennett, ibid.). ${ }^{9}$

This was not to be. Many of these new art museums were housed in former palaces or castles (for example, the Hradcany Castle in Prague, Le Palais

\footnotetext{
${ }^{8}$ Bennett's work on museums forms a critical part of my conceptual framework and is discussed more fully in the literature review.

${ }^{9}$ It is interesting that the New Labour Government in Great Britain (1997-2010) also introduced policies of cultural inclusion deliberately intended to solve some of the social ills of the country through involving more people in art and the art museum experience. For more on this, see Chapter Two of this dissertation.
} 
du Louvre in Paris, the Hermitage in St Petersburg and the Belvédère Palace in Vienna). Built by the wealthy for the wealthy these were imposing structures that may have been daunting to many of the "lower" classes. The National Gallery of Canada (formerly the Royal Academy of Canadian Art) while not founded in a castle or a palace was, nonetheless, housed at the Supreme Court of Canada in Ottawa, which was, in its own way, a different kind of imposing structure-as is the building of the Boston Museum of Fine Arts today.

Like art museum buildings, art collections themselves, both permanent displays and temporary exhibitions, were revered, and loud talking in the galleries was discouraged as stern guards with blank faces followed visitors from room to room to ensure appropriate behavior-the self-governing citizen notwithstanding. Similar situations exist in many public art museums today as various kinds of surveillance mechanisms (such as, security guards and video cameras) are used to ensure that correct protocols are followed. This in itself constitutes one kind of barrier. More than this, however, a number of discursive practices are at work behind the scenes, producing other kinds of barriers that may keep some potential publics out of the art museum altogether.

For example, many art museums lean heavily on private donors and corporate sponsors for ongoing financial support. This, in turn, has caused them to focus a great deal of effort on attracting and keeping wealthy supporters who are not always happy to have their cultural institutions invaded by the "undifferentiated masses" (Bennett's terminology, 2002, p.7). Retaining an air of elitism within the museum complex is one way to keep it exclusive. 
Paradoxically, money from entrance fees, exhibitions, shops and restaurants, etc., is also needed to help keep these institutions alive-thus the requirement to reach out to and attract wider audiences. ${ }^{10}$ It is this paradox that my thesis explores. My purpose is to expose some of the tensions these opposing interests produce as well as to determine how contemporary art museums can better serve their disparate publics.

The following chapter presents my theory, including my literature review, and my methodology. I first focus on works by Bennett (1995), Cameron (1971), Clarke (in Martine, 2006), Cotton Dana (in Anderson, 2004), Duncan (1995), Marstine (2006) and Preziosi (2003), all of whom address aspects of the art museum related to my thesis. To further support my arguments, I then review works by Bourdieu (2002), Gans (1999), Boltansky and Thévenot (1999), Rosengren (1995) and Thévenot (2007) for some social and cultural. These works form the basis of my conceptual framework.

\footnotetext{
${ }^{10}$ In the case of Tate Modern and of the NGC, where significant amounts of public money is involved, reaching out to wider audiences is partially a result of government policies.
} 


\section{Chapter One - Theory and Methodology}

\section{Literature Review}

\section{Introduction}

I begin my literature review by examining the notion of power and knowledge within the art museum environment. Tony Bennett's, book, The Birth of the Museum, is central to my discussion. Bennett develops a "politically focused genealogy" (Bennett, 2002, p.5) of museums from the early $19^{\text {th }}$ century to the late $20^{\text {th }}$ century, showing how the museum became not only a place of learning but also a "reformatory of manners" (Bennett, 1995, pp. 4-5). His book proper consists of nine previously published articles on the power/knowledge of museums, including art museums, in Western society. I follow my review of Bennett with a look at Carol Duncan's work on museum rituals, which also examines power and knowledge in the art museum environment-albeit from a different perspective. Preziosi's work on power and subjectivity provides me with some insight into how subjects are constructed—or construct themselves-within the art museum complex.

Next I look at the notion of art museums as "shrines" or "sanctuaries," drawing on works from Marstine (2006), Cameron (in Anderson, 2004) and Clarke (in Marstine, 2006). This idea is useful to me because it both supports my view that art can be enriching and helps to explain how many art museums became, and often still are, such revered or awe-inspiring places. The work of John Cotton Dana (in Anderson, 2004) on inclusion/exclusion is also helpful as it, 
too, reinforces my argument that art museums create hidden barriers that prevent some people from enjoying the art museum experience. Finally, I present a review of some theories put forward by Bourdieu (2002), Gans (1999), Boltansky and Thévenot (1999) and Rosengren (1995) and Thévenot (2007) on cultural institutions and social distinctions.

\section{Power/Knowledge Modalities in the Art Museum Complex}

In his book, The Birth of the Museum, Bennett lays out a genealogy of public museums, including public art museums, and identifies some of the problems confronting them as they opened up their doors to the "lower" classes in the early nineteenth century. As these new museums began admitting diverse publics, the problem of how to regulate their conduct became paramount (Bennett, 1995, p. 7). Bennett draws on Foucault to support his argument, comparing the museum to the penal institution to explain some of the ways in which this became tenable. He argues that, during the nineteenth-century, museums and other cultural institutions (fairs, exhibitions, amusement parks and even department stores) took on new roles that put them in league with governments in the observation and control of their various publics, suggesting that the exhibitionary complex was one place where the concept of a selfgoverning citizenry was first played out. The exhibitionary complex, he says, "sought to allow the people, and en masse rather than individually, to know rather than be known, to become the subjects rather than the objects of knowledge" (Bennett, 2005, p. 84). Bennett uses both Foucault's and Gramsci's work to advance his argument of the exhibitionary complex as a "set of cultural 
technologies concerned to organise [sic] a self-regulating citizenry" (ibid.). However, while he takes the Gramscian perspective that it is the role of the State to assume responsibility for the ethical and educative development of bourgeois democratic polity, he uses Foucault's work to unravel the relations between knowledge and power produced by the exhibitionary complex itself (ibid.). Foucault, himself, uses Bentham's Panopticon to illustrate how power and domination work in the modern episteme:

Bentham's Panopticon is the architectural figure of this composition. We know the principle on which it was based: at the periphery, an annular building; at the centre, a tower; this tower is pierced with wide windows that open onto the inner side of the ring; the peripheric building is divided into cells, each of which extends the whole width of the building; they have two windows, one on the inside, corresponding to the windows of the tower; the other, on the outside, allows the light to cross the cell from one end to the other. All that is needed, then, is to place a supervisor in a central tower and to shut up in each cell a madman, a patient, a condemned man, a worker or a schoolboy. By the effect of backlighting, one can observe from the tower, standing out precisely against the light, the small captive shadows in the cells of the periphery. They are like so many cages, so many small theatres, in which each actor is alone, perfectly individualized and constantly visible"

(Foucault, 1977, p. 200) 
To some extent, however, Bennett turns Foucault on his head, saying that if the modern prison resembles a Panopticon where everyone can be viewed from a central position, the modern exhibitionary complex ${ }^{11}$ is a place where everyone can both see and be seen. Yet for Bennett, the modern exhibitionary complex is not simply a reversal of the Panopticon; it is part Panopticon and part panorama, "forming a technology of vision" which regulates the crowd by rendering it visible to itself and thus making it "the ultimate spectacle" (Bennett, 1995, p. 90).

Bennett is careful to point out, however, that although museums opened their doors to the working classes they never actually represented working class values but, rather, were used by the dominant classes as a way of solidifying their own male, middle- and upper- class values as the norm for Western society (ibid. p. 30). Art museums, he argues, can be especially problematic because they play a role in segregating those who understand art-"those who can see..."-and those who don't (Bennett, ibid. p.164). Art museums, he claims, were (and are) complicit in creating and supporting social distinctions. That is, they were problematic because although they were opened up to a large number of different publics they were, at the same time, exclusionary because they refused to provide the necessary information required for less educated individuals to understand and/or enjoy the art within (Bennett, ibid. pp. 164-165). Bennett's work is important for my thesis as it provides a theoretical basis for my research. It tells me, for example, that social distinctions were built into art

\footnotetext{
${ }^{11}$ Bennett provides the Crystal Palace in London as the definitive example of the modern exhibitionary complex.
} 
museums from the very beginning; those without the "cultural capital" 12 to understand the art would not have enjoyed the art museum experience. I suggest, however, that it is not only a lack of understanding of the art that keeps some publics away from art museums, but also the hidden codes that make them feel uncomfortable in the art museum environment. It is some of these codes that my thesis explores.

Like Bennett, Carol Duncan (1995), in her book, Civilizing Rituals, also examines notions of power within the art museum-although her focus is not so much on how the working classes are controlled inside the museum as on how the museum, especially the art museum, empowers social elites who then take their power back out into the society at large. She suggests that the central meanings of art museums and their "ideological force" are structured through the rituals imposed on visitors by social/cultural protocols (Duncan, 1995, p.8). She argues that art museum spaces are sites for rituals, generated by donors and art museum professionals, and experienced by viewers. Within the art museum, Duncan claims, it is the visitors who enact the ritual (Duncan, ibid. p.12). Their aesthetic experience, she explains, is guided by their route through the museum. Furthermore, she says, the ritual experience itself is thought to be transformative: it "confers a new identity or purifies or restores order in the self or to the world through sacrifice, ordeal or enlightenment" (ibid. p. 13). The visitor to the art museum is expected to come away with a new awareness and a new understanding of what it means to be a modern bourgeois citizen. Those

\footnotetext{
${ }^{12}$ When speaking of cultural capital, I am referring to the work of Pierre Bourdieu (2002). Bourdieu is discussed in more detail later in this chapter.
} 
individuals who can best perform the rituals of the museum are also those the museum ritual most fully confirms. "What we see and do not see in art museums, and on what terms and by whose authority we do or do not see it, is closely linked to larger questions about who constitutes the community and who defines its identity" (ibid. p. 9).

Furthermore, Duncan argues that museums are not only sites for ritualsas important as that might be-but also "rich and interesting objects of social and political history" (ibid. p. 6). In the modern world, she says, "art museums constitute one of those sites in which politically organized and socially institutionalized power most avidly seeks to realize its desire to appear beautiful, natural, and legitimate" (ibid). She claims that art museums are controlled by "social elites"13 who, in North America at least, gain status through their donations, despite the fact that public money and public land are also used in the construction, maintenance and administration of these institutions (ibid. p. 8). That is to say that Duncan, like Bennett, and Bourdieu before him, believes that art museums are powerful constructers of social distinctions. She points out that in the past, art museums, housed in palaces or castles were often set apart from other buildings, usually in spacious grounds of their own. Architecturally, she adds, many contemporary art museums have equally imposing facades and are also set apart by structural markers. ${ }^{14}$ This, says Duncan, reinforces them as places outside of, and separate from, day-to-day time and space (ibid. p.11).

\footnotetext{
${ }^{13}$ By social elites Duncan is referring to the wealthy Americans ("bankers and business tycoons") who helped to found many of the public art museums in the United States (Duncan, 1995, p. 54).

${ }^{14}$ The Boston Museum of Fine Arts, for example, or the National Gallery of Canada.
} 
Like Bennett's, Duncan's work is important to my thesis because it asserts that art museums and similar cultural institutions not only favour distinctions within their walls but also help to perpetuate those distinctions in the society as a whole. That is to say, while art museums may have a need to court the wealthy from an economic perspective, doing so, whether deliberate or not, helps to reinforce power disparities within the community. My dissertation looks at how, in part, this is achieved.

\section{Power and the Construction of Subjectivities While Looking at Art}

Preziosi's (2003) book, Brain of the Earth's Body: Art Museums and the Phantasms of Modernity, allows me to see how people construct very specific subjectivities for themselves while looking at art and, I would add, participating in art museum activities. To understand what Preziosi means by this, it is first useful to look at Lacan (1977). Lacan claims that an individual's subjectivity is created in language, saying that in order for an infant to see itself as separate from its surroundings it needs to enter as a "speaking subject" into the language and law of what he calls the symbolic order-that is the language and law it its community (ibid., p. 147). Preziosi builds on Lacan when he says that individuals are constantly re-defining or re-confirming their identities and building selfesteem through contact with the objects they own in the real world-what he call their "stuff."

What I mean to say is that in modernity, you are made desirous of being convinced that you are your stuff, so that you may become even more desirous of being convinced that even better stuff will even more truthfully 
reflect your continually evolving character-what you shall have been, in other words, for what you are in the process of becoming. The desire to be so convinced, of course, is already itself prefabricated.

(Preziosi, 2003, p.20)

Buying a Versace gown or a BMW, he says, both enhances a person's identity and allows that person to enter into a specious or ironic relationship with him- or herself by knowingly participating in a kind of "masquerade" (ibid. pp. 2021). Objects in art museums, as well as other aesthetic experiences, work in the same way (Preziosi, 2003, ibid. p. 22). Art, he says, is imbued with things like values, ethics, beauty - things that people want to be associated with. Looking at art helps individuals to find their place, or place themselves, in the world. Art, Preziosi says, like language, is not just representation but discourse. Art helps to construct social realities just as other texts do, and people looking at art construct social realities and identities for themselves in the world (ibid. p. 118). Preziosi's concepts help me to analyse the ways in which the construction of subjectivity is commingled with knowledge and power within the art museum complex.

\section{The Art Museum as Shrine or Temple}

In the introduction to her book, New Museum Practice, Janet Marstine discusses the notion of the museum as "shrine." She argues that "one of the longest-standing and most traditional ways to envision the museum is as a sacred space," adding that "this is the iconic image to which many museums [especially art museums] still aspire" (Marstine, 2006, p. 9). Within the "paradigm of the shrine," she says, "the museum has a therapeutic potential." It 
is a "place of sanctuary removed from the outside world" (ibid.). This concept of the art museum as "holy" place has been, and is being, challenged by many artists, museum scholars and cultural theorists.

Nonetheless, the museum as temple or shrine was long championed by Sir Kenneth Clarke, formerly director of the National Gallery in London and host of the BBC television series Civilization. Clarke advocated that "The only reason for bringing together works of art is that ... they produce in us a kind of exalted happiness" (Clarke 1954, in Marstine, Ed., 2006, p. 9). The museum as shrine leads viewers to assign meanings to objects totally unrelated to their original function or intention. As such, Clarke eschewed wall plaques and other educational materials in order to foster a special relationship between the viewer and the art object—unencumbered by third party interpretations (ibid. p.9). That is, he was against the very things that might have helped less informed publics to enjoy the art museum experience.

The concept of the museum as a temple was also discussed by Canadian museologist Duncan F. Cameron-although Cameron feared that museums were losing sight of their original purpose. In his 1971 essay, "The Museum, a Temple or the Forum," Cameron argued that [Canadian] museums were "in desperate need of psychotherapy," adding that there is "abundant evidence of an identity crisis in some of the major institutions, while others are in an advanced state of schizophrenia"..."the crisis at the moment is that our museums and art galleries seem not to know who or what they are." Our institutions are unable to resolve their problems of role definition (Cameron, 
1971, in Anderson, Ed., 2004, p. 61). Cameron pointed to the Ontario Science Centre as an example, which, he said, started out as a museum but along the way turned into an "activity centre" which offers "an infinite number of buttons to push and cranks to turn ... interspersed with hot dog stands and purveyors of soft ice cream in a claustrophobic maze of cacophonous noncommunication" (ibid. p. 62). With this he appears to be saying that the new museum has gone too far in reaching out to attract mass publics into its (formerly) hallowed halls.

Cameron points out that even the Art Gallery of Ontario has had to accommodate new contemporary forms including "happenings," "electronic environments" and large exhibition halls where anything can "be tried or made to happen" (ibid.). He questions this "new" conception of the art gallery/museum—although he is not against museum reform-asking if these new centres would mean a loss of scholarship, of heritage and/or of excellence in the galleries. He argues in favour of "forums" for the introduction and exchange of new ideas, and for keeping the museum or gallery relatively "pure:"

[I]t is clear that there is a real and urgent need for the reestablishment of the forum as an institution in society. While our bona fide museums seek to become relevant, maintaining their role as temples, there must be a concurrent creation of forums for confrontation, experimentation and debate, where forums are related but discrete institutions...

(Cameron, ibid. p. 68) 
...continuing that the acceptance into the museum of the "untried and the experimental" would devalue those things that are properly of the museum (ibid. p. 70). However, Cameron's assessment that accepting the "untried and the experimental" would devalue traditional collections is somewhat problematic. Many modern/contemporary art museums have successfully combined the old and the new, the traditional and the avant-garde. In fact, accepting the "untried and experimental" has been seen as a way of attracting new audiences into the art museum complex. This leads me to the work of John Cotton Dana.

\section{Inclusion/Exclusion at the Art Museum}

As far back as 1917 John Cotton Dana, Director of the Newark Museum in Newark, New Jersey, in an essay entitled "The Gloom of the Museum," (Dana, in Anderson, 2004) wrote about the need to make "museums of art" much more inclusive. Art museums of the past, he says, have belonged only to the wealthy; their buildings have been remote, religious, autocratic or aristocratic in their style; their administrators aloof and unwelcoming, acting like "high priests of a particular cult, treating the casual visitor with tolerance only when he comes to worship rather than to look with open eyes and to criticise freely" (ibid. p. 21). Dana called for a new kind of museum, one that is located where it could be reached by the "maximum number of persons with a minimum of expenditure of time and money" and built of material and style appropriate for the modern city (ibid.). He criticised what he called the "undue reverence for oil paint" (ibid. p. 23) claiming that oil on canvass had little appeal to the average individual. He suggested that other types of pictures such as those found in 
posters, journals, newspapers and the cinema should be included to attract wider audiences (ibid. p. 23).

However, while it is true that the introduction of other art forms into the traditional art museum has brought larger numbers of people into the museum complex, the appeal of "oil on canvass" has never been lost. One has only to look at the throngs of people flocking to traditional summer blockbusters to see that its magic still remains. Nonetheless, it is the introduction of those other art forms, as well as the introduction of expanded shops, restaurants and other facilities, that is transforming the traditional art museum and making it more appealing to mass audiences.

These and other art museum theorists provide an intriguing look at public art museums from an art history, art criticism and museum studies perspective. My thesis takes a somewhat different approach. It treats art museums as "means of communication" and looks at how they connect with their various publics - both overtly through direct marketing and covertly through discursive practices. None of the literature I have reviewed addresses these issues directly. My thesis speaks to some of these omissions.

I turn now to some theories outside of art history and museum studies to round out my literature review and provide some insights into other aspects of the art museum experience.

\section{Class, Taste and the Forging of Cultural Capital}

In his book, Distinction: a Social Critique of the Judgement of Taste, Pierre Bourdieu argues that in modern western societies cultural practices have 
become the most important means of reproducing inequalities. The rich, he says, invest a great deal of money in education and art, which in turn, helps to perpetuate elitism and keep them apart (distinct) from the lower- middle- and working-classes. People from the low income classes, he says, are less likely to enjoy classical music, avant-garde literature, theatre and independent "art" films. His studies on museums and galleries have also shown that many working class people not only do not like much of the art displayed in contemporary art museums but also feel uncomfortable in such environments (Bourdieu, 1984, pp. $11-63 ; 261-264)$.

Class distinctions, says Bourdieu, are reflected in a person's tasteespecially in arts and culture-and stem from what he calls the person's habitus. The term habitus can be understood as those aspects of a person's culture that contain something from his or her past which functions within their present, shaping perception, thought and action and moulding social practices. It influences personality, attitudes, forms of know-how and competence at the level of unconsciousness: "[t]he schemes of the habitus, the primary forms of classification, owe their specific efficacy to the fact that they function below the level of consciousness and language, beyond the reach of introspective scrutiny or control by the will" (ibid. p. 466). The habitus is responsible for forming what Bourdieu calls an individual's or a family's "cultural capital." ${ }^{15}$

Bourdieu's work has been criticised by a number of social theorists including Luc Boltanski and Laurent Thévenot (1999), Karl Eric Rosengren

\footnotetext{
${ }^{15}$ Cultural capital, according to Bourdieu, is always defined by the dominant group.
} 
(1995) and Laurent Thévenot (2007) in Europe and Michèle Lamont and Annette Lareau(1988) and Paul DiMaggio (1979) in North America. Instead of labelling people according to social class, Boltanski and Thévenot developed a model in which people are judged by "plural orders of 'worth'". That is to say, a person's worth is constantly determined and re-determined by how he or she reacts in different situations (Boltanski and Thévenot, 1999, pp. 365-366). Thévenot argues against Bourdieu's sociology of agents in favour of a "'perpendicular' hypothesis about life in society" (Thévenot, 2007, p.410), claiming that people's social and cultural behaviours are determined not so much by "roles, social norms or social worlds" as by dramatic shifts in "ways of experiencing the world" (ibid.).

Rosengren argues that Bourdieu's conception of lifestyle is incomplete, claiming that his (Bourdieu's) structuralist Marxist approach to the analysis of class and culture in does not allow for choices based on individual agency (Rosengren, 1995, p. 14). To complete the picture, Rosengren argues, it is necessary to consider not only class and place of living (for example) but also patterns of "individually determined actions that distinguish between individuals who-regardless of the societal structure in which they live, regardless of the position they occupy-more or less consciously choose to shape their actions (and sometimes even their whole lives)" in terms of their individual values and attitudes (Rosengren, 1995, p. 14). Lamont, Lareau (1988) and DiMaggio (1979) all argue that Bourdieu's concept of the habitus is untenable-especially in North America. 
Bourdieu's work must be read in the light of these critiques. Nonetheless, there is much evidence to suggest that his theories of social distinction still have value within certain contexts. His concept of habitus is useful for my thesis because it allows me to understand some of the core experiences that help to form an individual's cultural likes and dislikes. At the same time, however, his argument that working class people do not like much of the art displayed in modern art museums may be unreliable as a generalisation. For example, Tate Liverpool launched a special project to train taxi drivers in 2007. The "Taxi Project" saw drivers taking part in ten weekly discussions at the museum, discussing contemporary art and, especially, the Turner Prize ${ }^{16}$. Drivers taking part in the project were encouraged to act as "cultural ambassadors," talking about contemporary art in general, and the Turner Prize in particular, and recommending that their passengers visit the museum (ibid.). The "Taxi Project" was considered a great success (Serota, 2010), with the majority of taxi drivers finding a new appreciation for contemporary art-something they had never before thought of as being for them (Liverpool taxi driver, Brian Bretherton, Tate Report, 2008). This tells me that there is nothing inherent about the working or low-income classes not understanding or liking art and suggests that there are other reasons why some of them may not visit art museums. This is consistent with my thesis that despite many changes over the last 40 years, public art museums still create hidden barriers that keep some potential publics away.

\footnotetext{
${ }^{16}$ The Turner Prize, named after the painter J.M.W. Turner is an annual prize presented to a British visual artist under 50 . It consistently provokes discussion, debate and controversy on modern and contemporary art.
} 
Like Bourdieu, Herbert Gans has also written extensively on class and taste. In his book, Popular Culture and High Culture: An Analysis and Evaluation of Taste (Gans, 1999), he uses the terms taste culture to describe various aesthetic choices and taste public to describe the people who choose them. Different taste cultures and taste publics exist, he says, because of the diversity of and disagreement about aesthetic standards and values. He argues, for example, that "[a]lthough all Americans consume art, high culture publics select their art from original oils and 'quality reproductions,' often in galleries, whereas other publics choose mass-produced originals and reproductions, bought at department store art counters; and the very poor may have to rely on calendars and magazine pictures which they hang on their walls" (ibid.). To this effect, he rejects the old notion that only high culture maintains aesthetic value while popular culture exists for non-aesthetic reasons. In fact, he subscribes to the idea of multiple taste cultures which he names aesthetic pluralism (Gans, ibid. p.94). ${ }^{17}$

Nonetheless, although Gans states that taste cultures are "not cohesive value systems" and taste publics are "not organized groups", he does maintain, like Bourdieu, that "the major source of differentiation between taste cultures and publics is socioeconomic level or class" ${ }^{18}$ (ibid. p. 95). Class he says can be defined by a person's income, occupation and education. This differs somewhat from Bourdieu's definition wherein significant emphasis is put on what class a person is born into in addition to levels of accumulated wealth and education. At

\footnotetext{
${ }^{17}$ Italics in the original

${ }^{18}$ Italics in the original
} 
the same time, Gans states categorically that in the United States, especially, low-and moderate-income people not only cannot afford to participate in elite cultural activities but also feel uncomfortable even at cultural institutions that charge no admission but are designed for the more affluent classes" (Gans 1999, p. 8). Gans proposes art museums as being perhaps "the best example of such places" citing a 1997 National Endowment for the Arts report that suggests that: "the arts community has long laboured under a stubbornly resistant class system of its own....[c]ultural equality remains as elusive as social, economic and educational equality" (Gans, 1999, p. 8).

These theories are useful to my thesis as I try to determine how the four art museums I have selected balance their various policies, procedures and practices to attract or deter multiple publics.

\section{Conclusion}

This is but a small sample of the writing on art and art museums available today. Within the fields of museum studies, cultural studies, communication and art history, to list just some, the output is prolific. However, while browsing through a great number of these works-many of which proclaim that art museums are elitist, that art museums need to become more inclusive or that art museums have already become sites of entertainment for the masses-nowhere did I find an examination of how these varying roles are accomplished. My dissertation examines this. By analysing such issues as member/donor benefits, art museum publications, buildings, shops, restaurants and websites, I expose some of the discursive practices that permeate the art museum environment and 
argue that, despite claims to be open to everyone, many of the signs emanating from these institutions produce barriers that prevent some publics from enjoying the art museum experience. I also suggest that these art museums, as "means of communication," are sending mixed messages to some of their potential publics. On the one hand their direct marketing materials portray them as inclusive and welcoming; on the other hand some of their practices suggest otherwise. Knowing what these practices are and identifying the barriers they create as "means of communication" will be my contribution to the field.

\section{Conceptual Framework}

\section{Introduction}

This section shows how the works examined in my literature review form the basis of my conceptual framework as I begin to explore the changing roles of public art museums over the last 40 years. These theories and thoughts on the place of the modern art museum in contemporary society allow me to ground my research on the National Gallery of Canada, the Boston Museum of Fine Arts, The Museum of Modern Art in New York and the Tate Gallery in London on a solid theoretical foundation.

\section{Discussion}

Each of the works discussed in my literature review provides an insight into the background and the modus operandi of the modern art museum and helps me to understand some of the knowledge/power modalities at work behind the scenes in many of these institutions. To this end, I have identified a number of themes which I use to support my discussion throughout this 
dissertation. First, I explore the museum as a "reformatory of manners" a place where the working classes were to be exposed to the cultural protocols of the middle- and upper-classes in an attempt to civilize them (Bennett, 1995, aided by Foucault and Gramsci). The argument that the exhibitionary complex served as both a Panopticon and a panorama in the production of self-governing citizens is useful to me because it shows how the museum came to be used by governments as a political tool not only for controlling the masses but also for creating standards of behaviour essential to the new citizen of modernity. That the modern museum became a place for such behaviour modification designed to construct a new ideal citizen in a new ideal world, in and of itself, is problematic, however. While museums, and especially art museums, claimed to be open to all of the various publics in any given society, only those individuals with the right cultural capital could, and can, really feel at home in such places. My thesis argues that the sense of elitism that permeated the art museum at the beginning of the $19^{\text {th }}$ century continues in the form of covert discursive practices in many art museums today—despite their obvious moves to become more inclusive.

A second theme to emerge from my literature review is that of the art museum as a "site of ritual," as a place where elite members of society can reconstruct their eliteness and take that eliteness back out into society (Duncan, 1995). This understanding of the art museum as a place where rituals are played out, where aesthetic experiences are moulded into narratives that define identities, and where visitors reinforce their sense of power in the community 
shows that art museums, despite all attempts to become more inclusive are still exclusive spaces from which many members of society are excluded-not overtly, but through covert processes and practices. As I examine the four case-study museums I have selected, I look for signs of eliteness and exclusion in their programs, publications, member/donor benefits, buildings, internal ambiance and other ways in which they construct the ideological discourses that support this claim.

The concept of "power and subjectivity" as part of the art museum experience (Preziosi, 2003) provides me with yet another theme on which to base my analysis. The notion that individuals construct identities for themselves while looking at art is central to my argument that art museums play an important role in the construction and preservation of social distinctions. We go to art museums because we like to look at art but perhaps we also go to art museums because we like to see ourselves, and be seen, as people who like to look at art-that is we like to see ourselves, and be seen, as members of an elite group at the top of the social pyramid. Clever art museum strategists and policy makers can tap into the idea of individual "specialness" or "uniqueness" when trying to attract wealthy donors. The very fact that some individuals "imagine" themselves as elite members of society helps to construct that very "eliteness" of which they are a part. Added to this is the fact that by recognising such eliteness, public institutions such as art museums help to maintain, construct and validate that eliteness. The entire process works as a kind of Mobius strip folding back on itself to keep the construct going. All four of the case-study art 
museums I have selected, for example, extend special recognition to donors who give generously either in terms of monitory benefits or artistic donations. Those donors respond in kind by continuing to support their art museums. This concept is taken up more fully in Chapter Three.

The art museum as a "shrine or temple" is another important theme that emerges from my literature review (Cameron, in Anderson, Ed, 2004, Clarke in Marstine, Ed, 2006, Duncan, 1995 and Marstine, 2006). While the thought that a visitor to an art museum might have a "transformative experience" (Marstine, 2006) or be filled with "exalted happiness" (Clarke, 1954, in Marstine, 2006) may seem quaint in today's postmodern world, it is not far from Deitch's claim (cited earlier) that art can change people's consciousness. Imagining the art museum as a shrine or temple, however, puts it in the realm of the exotic and highlights the notion, once again, of the art museum visitor, as "special" or outside of the everyday (Duncan, 1995).

The theme of inclusion/exclusion (John Cotton Dana) is important to my thesis as I look at ways in which the four art museums I have selected reach out (or not) to their various publics. Dana wanted art museums that were accessible to the "maximum number of persons with a minimum of expenditure of time and money" (Dana, in Anderson, 2004, p. 21) and he called for them to be built of material and styles appropriate for the modern city.

Finally, themes of class, taste and cultural capital (Boltanski, Bourdieu, Gans, Rosengren and Thévenot) run throughout my dissertation-albeit in the background-as I examine how public art museums interact with their various 
publics. These theories help me to show why many publics have been, and often still are, excluded from the art museum experience.

\section{Conclusion}

The themes I have discussed in this section form a framework for my thesis. As I proceed with my analysis, I look for ways in which the four casestudy museums I have selected manifest concepts of governmentality or reform Bennett (1995) or serve as places of ritual Duncan (1995). I try to determine ways in which they might be seen as shrines or temples (Cameron, 1971, Clarke, in Martine, 2006, and Marstine, 2006) and I look to see if any of these museums fulfil Cotton Dana's plea for easy access and materials befitting a modern city (Cotton Dana, in Anderson, 2004). I examine notions of the modern subject to determine what role these four art museums might play in the construction of identities (Preziosi, 2003) and the creation of social distinctions (Bourdieu, 2002, Gans, 1999) in our society. As I examine how these museums as "means of communication," speak to their various publics, I draw on these ideas to help support my argument that while public art museums have changed significantly over the past 40 years they still retain an air of elitism that keeps some members of society away. 


\section{Methodology}

\section{Introduction}

This section sets out my methodology. It describes the approaches I use, identifies the main aspects of my analysis and sets some limitations for my research.

\section{Discussion}

To explore the changing roles of public art museums as they try to attract more diverse publics and continue to appeal to their elite audiences, I use a variety of approaches (for example, critical discourse analysis, multimodal discourse analysis, semiotics, social/historical analysis and interpretation) not only to analyse policies, practices and communication strategies at the National Gallery of Canada, The Boston Museum of Fine Arts, The Museum of Modern Art and Tate Modern, but also to uncover some of the "hidden" messages I believe to be at work behind the scenes .

My analysis relies heavily on semiotics as a tool for decoding some of the myths ${ }^{19}$ produced within the art museum environment. That is to say, I look at how meanings are made and disseminated through language, images and social practices. This part of my research is informed by the work of Roland Barthes (Barthes, 1972, 1994) and by that of Marita Sturken and Lisa Cartwright (2001). For example, I use Barthes' method of unpacking words and images in Mythology and The Semiotic Challenge and Sturken and Cartwright's theories in

\footnotetext{
${ }^{19}$ This reference is to Roland Barthes' Mythologies, 2001. Barthes used the term myth to refer to the hidden codes and social practices that universalized the values of certain groups at the expense of others.
} 
Practices of Looking to help me analyse how the four art museums I have selected, as "means of communication," covertly perpetuate elitist discourses while overtly trying to be more populist.

In addition to semiotics, my analysis is also informed by critical discourse ${ }^{20}$ analysis -in particular, but not exclusively, by the work of Norman Fairclough. Fairclough views discourse as a form of social practice and looks at ways social and political powers are reproduced in texts (Fairclough, 2005). He takes a three-dimensional approach to discourse analysis which maps three separate forms of analysis on to one another: the analysis of language texts, the analysis of discourse practices and the analysis sociocultural practices (ibid.). That is to say, Fairclough is interested in the relationships between sociocultural events and the discourses that shape, and are shaped, by these relationships. He extends his concept of "text" to include not only written texts but also images and symbols. "I take 'texts"' he says "to be the linguistic/semiotic elements of social events, analytically isolable parts of the social process" (Fairclough, ibid. p. 2).

For Fairclough, critical discourse analysis investigates the "interdiscursive elements of texts: the linguistic and semiotic elements, the social production and consumption of the texts and the social practices that change and are changed by the discourse" (Fairclough, 1995). Fairclough's work is useful for my thesis because it examines language, images and discourses in relation to ideology and power, and the role of both of these in the processes of cultural and social change. Unlike some discourse analysts, however, Fairclough does not include

${ }^{20}$ For discourse I take Fairclough's meaning of "different ways of representing the world" (Fairclough, ibid. p. 215). 
built environments and their interiors in his definition of texts. I have chosen to include these in my analysis because I believe, like Duncan $(1995, p .10)$ that buildings can communicate powerful messages of inclusion or exclusion to their users.

My research proper contains several different types of information: history and social/political theories; government and corporate policies; surveys and various feedback data collected from museum staff; communications and marketing materials; the roles of various actors (visitors, members, donors and benefactors) and an analysis of the physical space both outside and inside (i.e. the architecture and ambiance, restaurants, bars, cafés and shops) of the museum complex. I have chosen to include all of these to determine to what degree, if any, they are complicit in creating the hidden barriers that, I believe, keep some publics away from art museums.

To collect information on member/donor privileges, I developed a simple yes/no survey questionnaire with one open ended question related to the yes/no answers which was cleared by the Ethics Committee at Carleton University and sent to the membership secretaries of the four case-study museums. Three of them responded; that information can be found in Annex A. The fourth, Tate Modern, referred me to its website, which is where my data for that museum comes from; this is also included in Annex A. Other data (policies, programs and information about exhibitions, etc., as well as images of people) were also found on the respective museum websites. Policies are important because they provide some insight into the how or why of museum operations; programs and 
other information on exhibitions, for example, let me see where these museums focus most of their energy. Pictures of people show me who, to some extent, these museums are targeting.

The first type of data in my dissertation, a brief history of art museums and a discussion of some social and political theories of the late eighteenth and early nineteenth centuries, provide a background to my argument that art museums (as opposed to the palaces and castles that originally housed most fine art) in addition to being created as repositories of manners for civilizing the working classes (Bennett, op cit.) were also conceptualised as sites for the validation of a growing bourgeois public and a growing bourgeois public sphere (Duncan, op. cit.).

The next type of data, an examination of government and corporate policies, articulate some of the reasons for the changes that are taking place in public art museums today. These are examined for both content and intent. For example, the British government's GLLAM Report ${ }^{21}$ makes it clear that, if they are to receive public funds, British museums and art galleries must work towards greater social inclusion. My thesis looks at these policies and other government documents from Canada, the United Kingdom and the United States to determine the impact they have had on the way art museums have developed and changed over the past 40 years.

The third type of data are concerned more directly with the four case-study art museums as "means of communication" and with the various actors and/or

${ }^{21}$ Group for Large Local Authority Museums (October 2000). 
programs, activities, texts, images and practices that contribute to the art museum experience. For example, I analyse the National Gallery of Canada's Vernissage, the Boston Museum of Fine Art's Preview, The Museum of Modern Art's MOMA and Tate's Modern's TATE ETC. ${ }^{22}$ My reason for analysing these magazines is that I believe art museum publications, especially magazines and journals, tell a lot about the kinds of institutions that produce them and the kinds of publics they are trying to reach. The magazines I have chosen also reveal much about the kinds of art these museums exhibit and the kinds of programs/activities they support. Furthermore, magazines and journals can reach a broad spectrum of publics, especially those who prefer a tactile connection with information, or those not connected to, or not interested in, the internet. From a methodological perspective I have used a strategy of choosing random samples of these magazines since a pre-selection strategy might have compromised the objectivity of my thesis by unintentionally supporting my argument. That said these magazines are fully representative of the four art museum publications as a whole.

In addition to the articles in these magazines, I also analyse the advertising in two of them to determine which publics it speaks to. Unfortunately, the MoMA ceased publication of its magazine, MoMA, in 2002, so although I was able to find back issues on JSTOR ${ }^{23}$, this part of my research is limited by the fact that none of the advertising was available. As well, the MFA's Preview does

\footnotetext{
22 TATE ETC is not published exclusively by Tate Modern but is a shared publication with Tate Britain, Tate Liverpool and Tate St. Ives.

${ }^{23}$ My access to JSTOR has been exclusively through the Carleton University Library.
} 
not include advertising, making it impossible to analyze the advertising in all four publications. Another limitation to my research might be that I did not communicate formally with visitors as I was focused more specifically on the ways in which the four case-study museums selected functioned outwardly as "means of communication."

My fourth type of data, which is also directly concerned with the casestudy museums, includes the analysis of museum architecture/space and ambiance (including restaurants, bars, cafés and shops) to determine what messages these museum buildings and facilities communicate, and to what degree they either welcome or deter would-be visitors. Research for this study was done through participant observation and draws on works by Umberto Eco and Roland Barthes. In his essay, "Function and Sign: The Semiotics of Architecture" Eco (in Leach, Ed., 1997) suggests that buildings, that is, built structures, do or can, communicate, saying that they have connotative as well as denotative meanings (ibid. p. 182). Both denotative and connotative meanings, he explains, are communicated through architectural codes and sub-codes that have developed over many millennia of history (ibid. p. 184). That is to say, there are sign vehicles that denote both precise functions (denotative meanings) and produce successive meanings by way of connotation, on the basis of further codes (ibid.) This, he says, "is the semiotic universe in which a reading of architecture as communication becomes visible" (Eco, ibid. p. 185). He points out that the architecture of a contemporary exhibition, for example, while first allowing people to enter, to circulate and to view the exhibits, is primarily a 
means of communication, used to convey the values of a culture or the image of a civilization (ibid, p. 204). It is the functional nature of buildings, Eco suggests, that often prevents us from seeing them as messages or as media of communication (ibid, p. 202). When speaking of architecture, Eco includes items of both industrial and urban design as well as built structures, echoing Barthes, who wrote that "as soon as there is a society, every usage is converted into a sign of itself" (Barthes, 1968; also cited by Eco, ibid.). Like Eco, Barthes advocates the communicative nature of built environments. ${ }^{24}$ This concept of architecture and design as communication is useful for me as I examine not only the buildings of my four selected art museums but also their interiors, including their viewing rooms, restaurants, bars, cafés and shops to determine if they are in any way complicit in generating messages of exclusion.

My research also includes an analysis of the four museum websites for content, visual impact and usability as well as for myth-making and ideology. My purpose in studying these websites is to determine what effects new technologies are having on the inclusion/exclusion debate. Websites are now a primary method of communication for most cultural (and other) organizations, large and small. As more and more individuals have access to the internet, institutions like art museums have an opportunity to reach unprecedented numbers of people. The amount and variety of information available through this medium could help less knowledgeable or less advantaged individuals gain not

\footnotetext{
${ }^{24}$ Barthes provides examples of both a city (Paris) and a building within that city (the Eiffel Tower) as signifiers of a great many denotative and connotative meanings (Barthes, in Leach 1997, p. $166-180)$.
} 
only an understanding of art but also of art museum protocols; in other words, it could help them acquire some much needed cultural capital.

The work of Gunter Kress and Theo van Leeuven is important to my investigation of these websites. Kress and van Leeuven advocate a theory of multimodal discourse analysis which takes into consideration an assortment of semiotic resources which can be used to create meanings: written language, images, video, music, spoken language, architecture, for example, (Kress and van Leeuven, 2001). Drawing on the work of Michael Halliday $(1978,1985)$, they argue that a single approach to the analysis of new technologies is no longer sufficient. New technologies, they suggest, work both "interactively" and "separately" to "speak" to their audiences, arguing that "within a given socialdomain the 'same' meanings can often be expressed in different semiotic modes" (Kress and van Leeuven, 2001, p. 1). Thus, an approach which takes these different modes into consideration is needed in order to understand how new media work. A website, unlike a traditional text, for example, does not follow a linear progression from start to finish but allows a user to enter at any point, move back and forth between screens and create his or her own story. Or, as Richard Hallett and Judith Kaplan-Weinger (2010) suggest in their book, Official Tourist Websites: A Discourse Analysis Perspective, a website allows individuals to construct new subjectivities for themselves by moving through its pages according to their preferences (Hallet and Kaplan-Weiner, 2010, p. 5). At the same time, they argue, organizations can also create their own independent identities depending on the messages they wish to send (ibid. p. 7). As Kress 
and van Leeuven have shown, "websites make meaning in multiple articulations" (Kress and van Leeuven, 1996, p. 4). This non-linear nature of a website demands a non-linear approach to analysis.

\section{Conclusion}

This section of my chapter has presented some of the steps I take to complete my research and analyse my data. The paragraphs below provide a brief roadmap through my dissertation. This chapter, for example, has provided my theory and my methodology. Chapter Two examines the move from class culture to mass culture: social changes, government policies and the move towards democratization of public art museums. It begins with an overview of private collections followed by a short history of public art museums, examining the establishment of these institutions in order to provide a baseline for discussing their changing roles. It shows, for example, how with the advent, first of advanced capitalism and then of modernism and beyond, the old concepts of class have been eroded to make way for a social hierarchy based not so much on birthright and elite education but on accumulated wealth and mass education. This chapter also examines some of the government policies and public expectations that have led to changes in public art museums over the last 40 years.

In Chapter Three, I look at ways that the Boston Museum of Fine Arts, the National Gallery of Canada, the Museum of Modern Art in New York and Tate Modern in London attract or exclude their publics through a variety of different discursive practices. I examine the roles of members, donors and other 
benefactors, for example, to determine their participation in elite activities within the four case-study museums. I look at ways in which these museums reach out to wealthy supporters through special events such as receptions and banquets, private viewings and public recognition. Finally I analyse various components of the museum experience such as exhibitions, publications, lectures, films, music, educational and community outreach programs and children's programs. I argue that, despite their claims to be reaching out to more diverse audiences, some of the hidden messages these four museums send help to construct and perpetuate social boundaries that keep a number of their would-be publics away.

Chapter Four examines the architecture and ambiance of these four museums to determine what role(s) it plays in the inclusion/exclusion debate. Using works by Barthes, Eco and others I show how these built environments have both denotative and connotative meanings that can contribute greatly to how potential visitors interact with them. Here I take my cue from Duncan who argues that many art museum buildings are set apart by structural markers that reinforce them as places outside of, and separate from, day-to-day time and space (Duncan, op. cit.). In addition to analysing the buildings themselves, I also examine their restaurants, cafés, bars and shops and argue that these, too, send many different messages to would be visitors. For example, I argue that highend restaurants and exclusive shops (the MoMA Design Store, for example) provide one more opportunity for some elite members of society to practice their eliteness. Furthermore, I suggest that while all of these museums provide facilities for less elite visitors, many of these same facilities, especially cafeterias, 
snack bars and vending machines, are relegated to less attractive parts of their respective buildings. This, 1 argue, also sends a message of exclusion and is one more way of constructing and supporting social boundaries.

Chapter Five examines each museum website for content and usability as well as for messages of inclusion and/or exclusion. It looks at the kinds of information available, the level of language used and the images portrayed. It tries to determine, after Hallett and Kaplan-Weinger (2010), just what kinds of subjectivities individual viewers might construct for themselves while looking at these websites. It suggests that, at the end of the day, art museum websites could become democratizing agents for all of these institutions. That is to say, the amount and variety of information provided here could help less knowledgeable or less advantaged individuals gain not only an understanding of art but also of art museum protocols; in other words these websites could help them acquire some much needed cultural capital because they do not rely solely on written language.

Chapter Six presents a summary of findings and serves as the conclusion to my thesis. Additional information can be found in the annexes. 


\section{Chapter Two - From Class Culture to Mass Culture: Social Changes, Government Policies and the Democratization of Public Art Museums}

The highest experiences of art are only for the elite who have earned in order to possess.

James Johnson Sweeney, Director of the Guggenheim Museum (1961) ${ }^{25}$

\section{Introduction}

This chapter examines the dichotomy between the stated role of the early public art museum and its actual roles as they unfolded. For example, the stated reason for the opening of public art museums in England was that they would provide a vehicle for education, or as Bennett has claimed, a reformatory of manners, for the general public; however, that "general public" was mostly limited to the upper and already educated classes of society (Bennett, 1995). That is to say, while public museums, including public art museums, were designed to attract all levels of society, only those individuals with the right cultural capital could really enjoy the experience and feel at home in such institutions. This reinforces the idea that social distinctions, such as those exposed by Bourdieu (2002) and Gans (1999) were built into public art museums from the very beginning. The myths surrounding them were, and sometimes still are, elitist and exclusionary. At the same time, if we argue like Kress and van Leeuven, for example, that all social discourses are culturally and historically specific (Kress and van Leeuven, 2001, p.4 ), we need to look at what changes to society might

\footnotetext{
${ }^{25}$ Ibid.
} 
have affected changes to public art museums over the years since they were first conceived.

To that end, this chapter traces the shift from class culture to mass culture as defined by contemporary social and cultural theory and theorists. It shows how with the advent, first of advanced capitalism and then of modernism/ postmodernism, the old concepts of class were worn away to make way for a social hierarchy based not so much on birthright and elite education as on accumulated wealth and mass education. It examines the transfer of power from the exclusive enclaves of the aristocracy to the relatively widespread reach of the bourgeoisie and beyond. It discusses the emergence of the bourgeois public sphere (Habermas, 1991) and the role of the public art museum in the construction and validation of this "new ruling elite" (Lash, 1990).

In addition, this chapter examines the later demise of that same ruling elite and the ascent, first of modernism, and later of a new bourgeoisie (Lash, 1990) with its focus on market forces, commodification and consumerism, and whose values stem from the post-1968 student and labour "uprisings" in Europe and North America, the "end of history" and the onset of "postmodernism" as the new milieu in which "anything goes." That is, it examines the move from class culture to mass culture, the inculcation into many of our institutions of the newly educated working and lower-middle class individuals, and the concomitant rise of popular culture. It shows the role played by class, taste, the habitus, the forging of cultural capital, knowledge, power, hegemonies and subjectivities, first in the formation of public art museums and then in the partial transformation of those 
same museums from elite galleries belonging to the aristocracy, first to social symbols for the emerging bourgeoisie and, then to possible places of entertainment for the newly educated and increasingly demanding masses.

Finally, this chapter examines some of the government policies and public expectations that have led to many of the changes in public art museums over the last 40 years, even as they retain some of their elite origins.

\section{A Short History of Art Museums in Western Europe and North America}

\section{Western Europe}

The genesis of the public art museum, as we now know it, grew out of the many private collections accumulated by kings, princes, noblemen and other wealthy patrons prior to the eighteenth century (Alexander, 1979, Duncan, 1995, McClellan, 2008). For European royalty and its aristocratic followers, art became a sign of social standing and cultural superiority. In France, the duc de Berry was a great medieval collector. The Hapsburgs, as Holy Roman Emperors, drew on German, Italian, Spanish and Flemish art to complete their collections. Habsburg Emperor, Rudolph II, had an impressive collection of art in his Hradcany Castle in Prague. However, during the Thirty Years' War (1618-1648), Gustav Adolphus of Sweden captured Prague and moved many of Rudolph's treasures from Prague to Stockholm. Gustav's daughter, Christina, later took most of them with her to Rome (Alexander, 1979, p. 20). In Spain, the Habsburgs acquired Italian, German, Flemish and Spanish paintings for their palaces at the Prado, Escorial and Alcazar (Alexander, ibid.). 


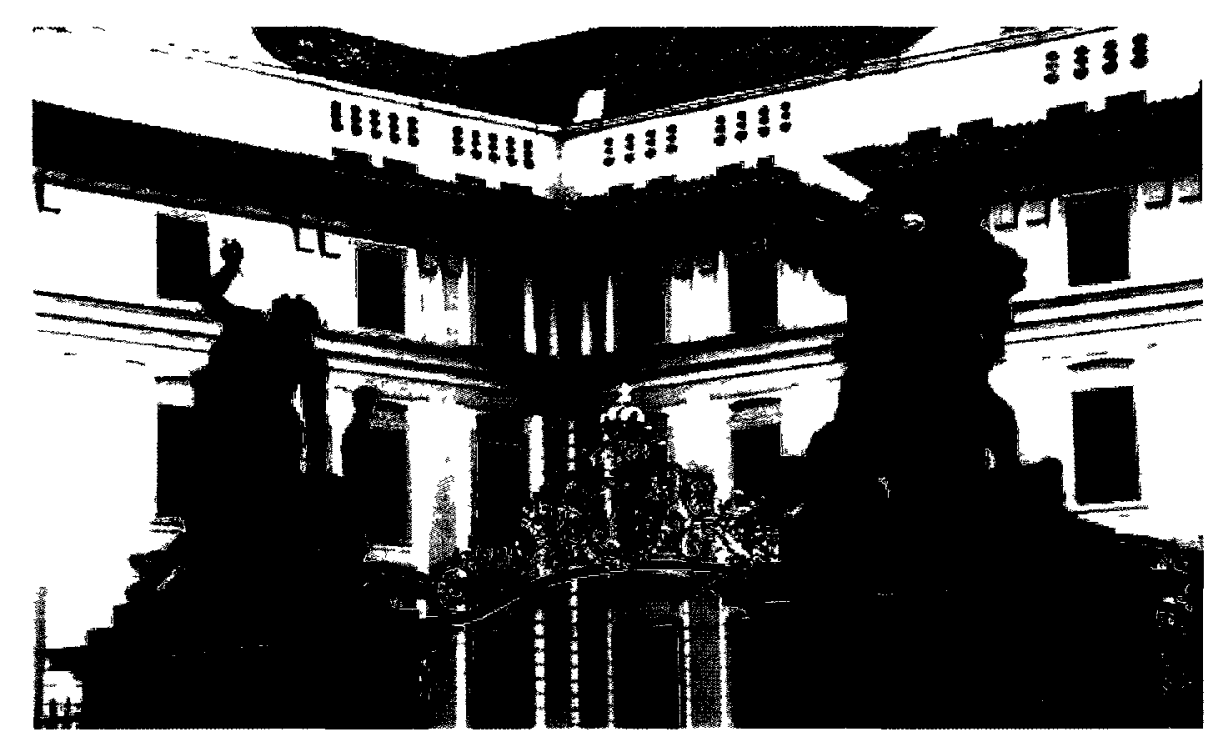

Hradcany, the Prague Castle, (Photo: www.prague.net, 2008)

In Italy, after the Renaissance, the Medici in Florence accumulated many great works of art and generally supported the arts for their own aggrandizement. For example, Cosimo de' Medici (1519-1574) hired court painters and helped to found an artists' academy in Florence to develop a series of images that reflected Medici power and dynastic rule. The painters Pontormo (1494 - 1556) and Agnolo Bronzino (1503 -1572) "fashioned a court portrait style for the Medici, characterized by courtly grace and opulence and often overflowing with complex allegories relating to power and military might" (The Art Institute of Chicago website, May 2010). Bronzino and his assistants produced a large number of portraits of Cosimo, his wife Eleonora, and their children and of the grand duke's distinguished ancestors and of members of his court (The Art Institute of Chicago website, May 2010). In Cosimo de' Medici, we clearly see the use of art to gain power and status in society. 
In England, Charles I, while still Prince of Wales, invested over $£ 80.000$ in paintings and other objets d'art, including Raphael's seven original cartoons for The Acts of The Apostles tapestries (Alexander, 1979, p. 20, Duncan, 1995, p. 34). Charles I, in fact, was a great patron of the arts throughout his life; at the height of his power his collection contained "1387 paintings and 399 sculptures including works by Raphael, Correggio, Tintoretto, Titian, Leonardo and many others" (Alexander, ibid.). He even commissioned a regal palace to display it all (Duncan, 1995, p. 34). However, this collection was dismantled with his demise and auctioned off by his Puritan executioners in an attempt to negate such a "quintessential sign of regal absolutism" (Duncan, 1995. p. 34). Royal monarchs in England after Charles I no longer displayed their collections in quite such an ostentatious way (Duncan, ibid.). However, British royal collections were never transferred to public art museums to the same extent they were in other countries. The British royal family still has an extensive collection today (Duncan, ibid. p. 35).

The French royal collection grew considerably during the $17^{\text {th }}$ Century when Marie de Medici, who married Henry IV of France in October 1600, summoned Rubens to Paris to paint scenes from her life. In addition, Cardinal Richelieu was responsible not only for helping the king acquire Italian and French art but also for building, in Paris, the Palais Cardinal-later to become the Palais Royal-to house "jewels, religious plates, 500 pictures, 50 statues, bronzes, tapestries, textiles, furniture, and Chinese lacquers and ceramics" (ibid. p. 21). 


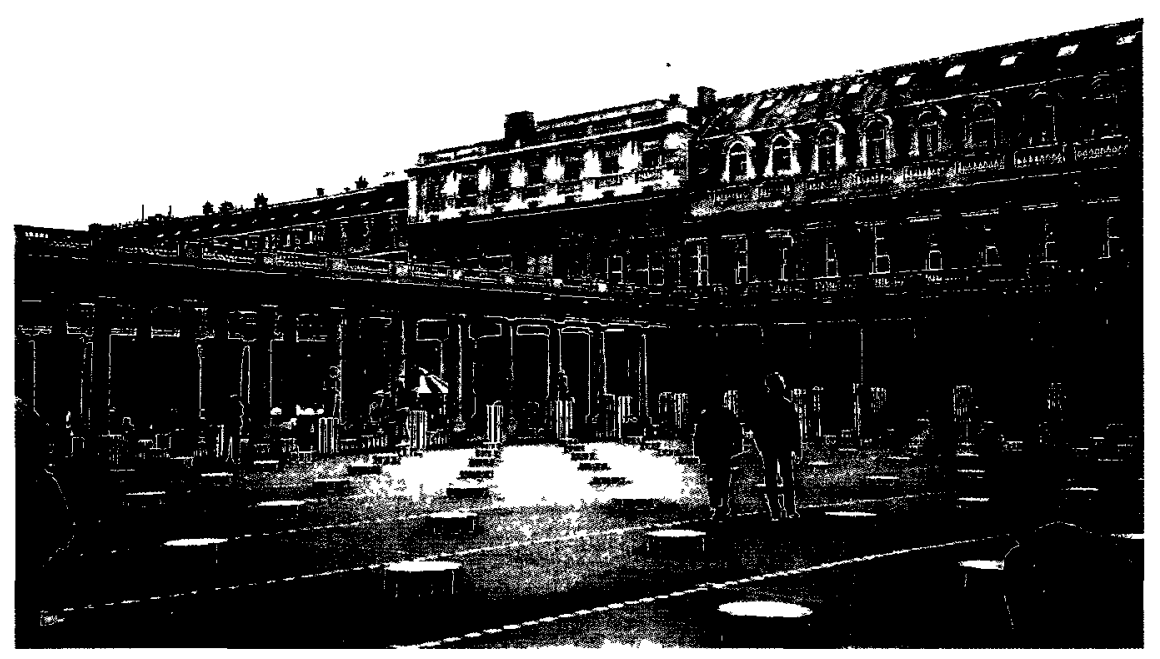

Palais Royal, Paris, (Photo: Wendy Quinlan-Gagnon 2002)

When he died, Richelieu was succeeded by Cardinal Mazarin who, on his death, left 546 paintings most of which were purchased by Louis XIV. JeanBaptiste Colbert, Secretary of State from 1669, continued to add to the royal collection. He later purchased, for the king, 101 paintings and 5,524 drawings from a Cologne banker (Alexander, 1979, ibid.).

Saint Petersburg also became a great centre of art, with first Peter the Great, and then Catherine the Great, acquiring extensive collections. Catherine, a self-described "glutton for art," began buying for her museum in 1764 (Alexander, ibid. p. 22). By 1769 she had bought two of the greatest collections of drawings in Western Europe. One of them belonged to Count Cobenzl, then living in Brussels, who was minister plenipotentiary to Empress Maria Theresa of Austria and a leading figure in the administration of what was then the Austrian Netherlands. She also bought over 1,020 drawings from the collection of Count Heinrich Bruhl, who was at the time a minister at the court of Saxony in Dresden, 
and she acquired almost 2,000 drawings from the collection of Count Butskoy, the former president of the Imperial Academy of Fine Arts in St. Petersburg (ibid.). In addition, she obtained over 2658 paintings and, in order to house them, began building the Hermitage in Saint Petersburg in 1767 (Alexander, op. cit., p. 22).

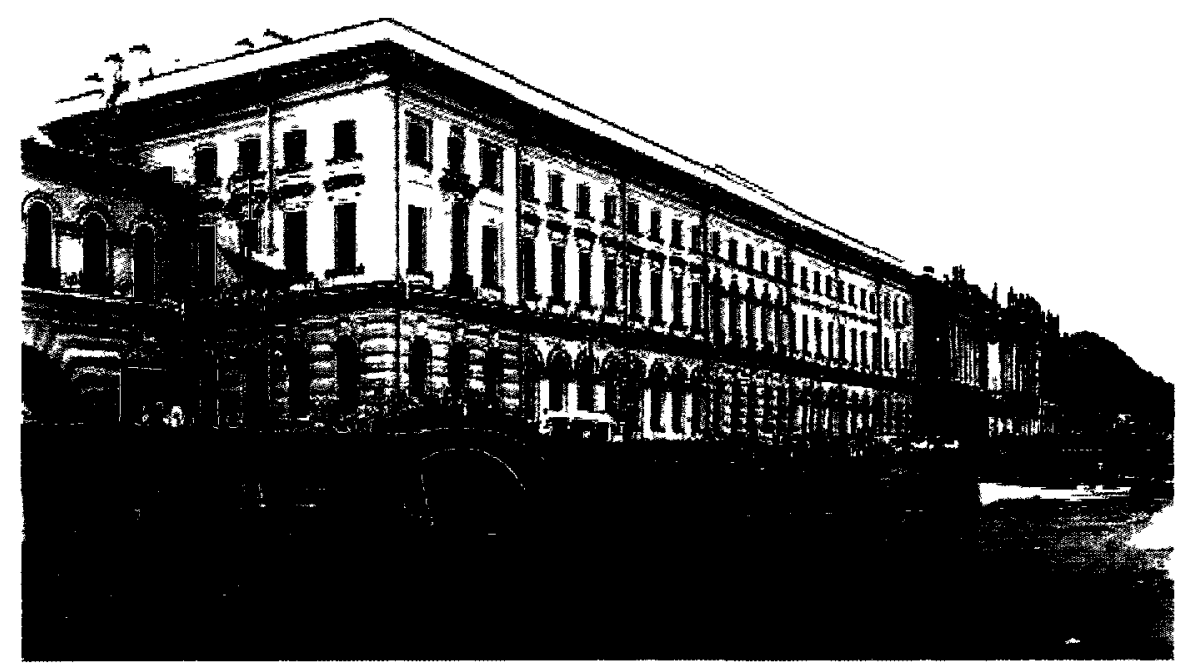

The Hermitage Museum, St Petersburg (Vladimir Batarin, Google Earth, ID: 5687503, n.d.)

These royal collections were used to demonstrate the monarch's power, first to immediate supporters-"courtiers and nobility" and "rivals in other states"-and later, (but to a lesser extent), to the public (Bennett, 1995, p.26). For the most part, though, art collections formed "part of the cultural accessories of power within and between ruling strata rather than the display of power before the populace" (Bennett, ibid. p. 27). Nonetheless, when the art collection of Francesco I de' Medici was transferred to the Uffizi Gallery in 1584 it was to confirm the legitimization of the Medici dynasty (Bennett, ibid.) The opening up 
of this royal collection to the people was for the "glorification of the prince, the celebration of his deeds and the power of his family" (Bennett, 1995, p. 10).

During the $18^{\text {th }}$ Century, England, and especially London, became a centre of collecting. Money obtained from commercial success in the colonies allowed the British nobility to build great houses and fill them with paintings, sculptures and other objet d'art (Alexander, 1979, Duncan, 1995). London overtook Amsterdam as a centre of art sales and came close to surpassing even Paris (Alexander, 1979, p. 20, Duncan, 1995, p. 35). Collecting art became one of the ways in which the "upper ranks" of British society formed its common class identity, seeing themselves as the "cultural, social and political core of the nation" (Duncan, 1995, p. 36). Putting their collections on display allowed them to demonstrate both their wealth and their power. However, as both Bennett (1995) and Duncan (1995) have pointed out, these works were only shown to "publics that mattered: well-born, educated, men of taste, and, more marginally (if at all)," to "well-born women" (Duncan, 1995, p. 36). However, as more and more people had access to education, allowing them to acquire the requisite "cultural capital," these publics widened to include not only the wealthy but also the intellectuals and the educated middle classes. Nonetheless, it is this legacy of elitism, I claim, that lingers on in many of our public art museums today, Towards the end of the late $18^{\text {th }}$ century, many of these private collections were turned into public art museums. In France, Le Palais du Louvre was opened to the public during the French Revolution. Leaders of the revolution 
believed that art belonged to the people and a national museum was launched in the Louvre in 1793 (Bennett, 1995, pp. 36-37).

Most of the art in the Louvre came from private collections, the rest from churches and religious orders. In addition, revolutionary armies brought art from Antwerp, Brussels and other cities when Belgium was captured in 1794. Even more treasures were brought to the Louvre as well as to the Bibliothèque Nationale and Le Jardin des Plantes during the Italian campaign of 1796-97 (Alexander, 1979, op. cit.). The Grand Gallery of the Louvre exhibited 537 paintings on its walls and 134 objets d'art on tables in the centre of the hall (ibid.).

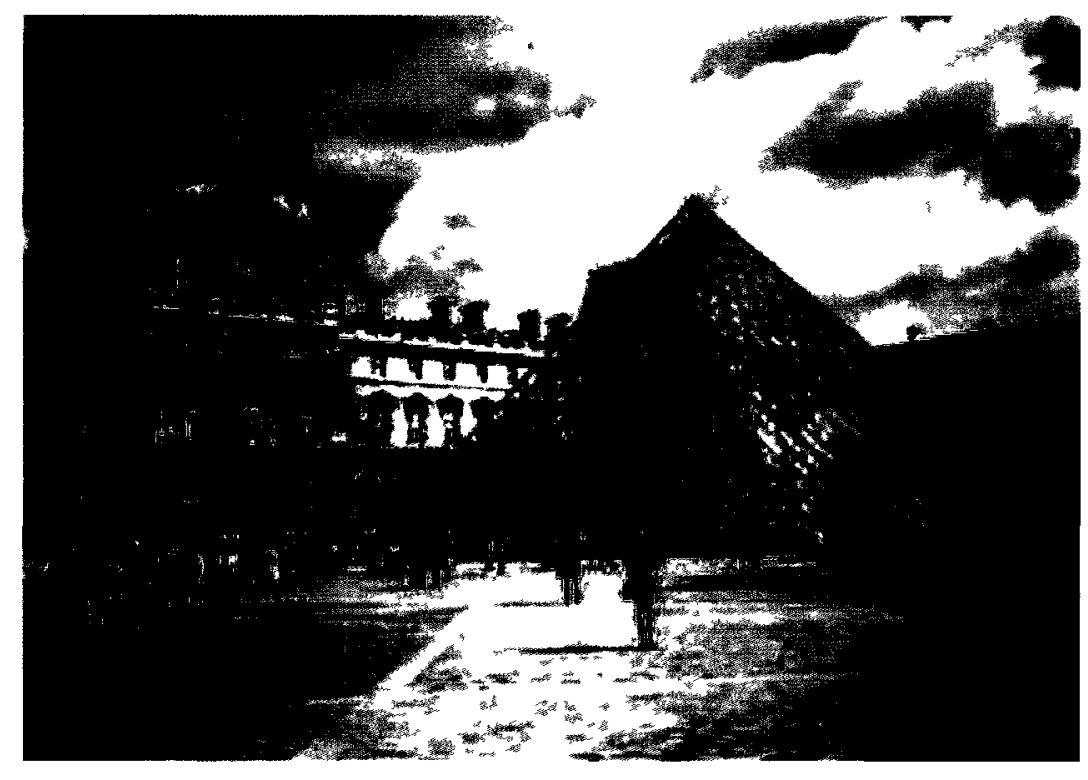

Le Palass du Louvre

(Photo: Googleimages com)

In Britain, Sir Hans Sloane's collection, purchased by the government for the pleasure of the British people, opened as the British Museum in 1753 
(Duncan, 1995, p. 142). In Vienna, the private Hapsburg collection was

transferred to the Belvedere Palace in 1776 and, in 1781, the general public was admitted to this collection for the first time (Alexander, ibid. p. 22, Bennett, 1995 , p34). General collections in Düsseldorf, Munich, Kassel and Dresden opened around 1750-although, as Bennett points out, these were not public art museums in the modern sense (Bennett, 1995, p.34-35). They remained, to some extent, "royal" collections (ibid.).

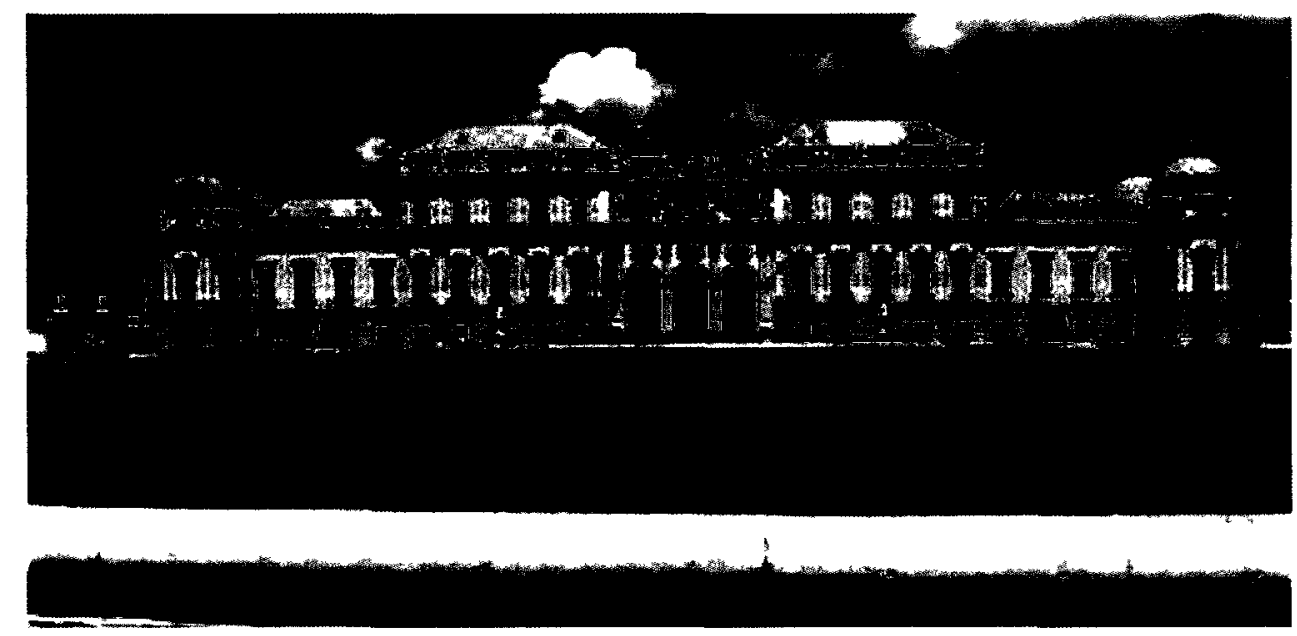

The Belvedere Palace, Vienna (Photo: virtualtourist.com)

The nineteenth and early twentieth centuries, however, saw the opening of many more public art museums throughout Europe until almost every country had its own collections. The Louvre grew exponentially during this period and in London the National Gallery opened its doors for the first time in 1824 (Alexander, op. cit.) In Prussia ${ }^{26}$ the Hohenzollerns founded the Museum Island in Berlin which included the Alte Museum (1830), the Neue Museum (1859) and

\footnotetext{
${ }^{26}$ Prussia became part of Germany only in 1870 , during the Franco-Prussian war when King Wilhelm I proclaimed the reunification of Germany on $25^{\text {th }}$ December at Versailles and himself as its first Kaiser (Martin Michèle, 2006, Images of War. University of Toronto Press)
} 
the Kraus Friederich Museum of Western Art (1904). A string of other art museums were opened during this period, including the Luxembourg Palace (1818) and the National Museum of Modern Art-now the Centre George Pompidou-in Paris (1937), the Neue Pinakothek (1853) in Munich and the National Gallery of British Art (1897)—now Tate Britain—in London (Alexander, 1979, p. 30, McClellan, 2008, p. 20).

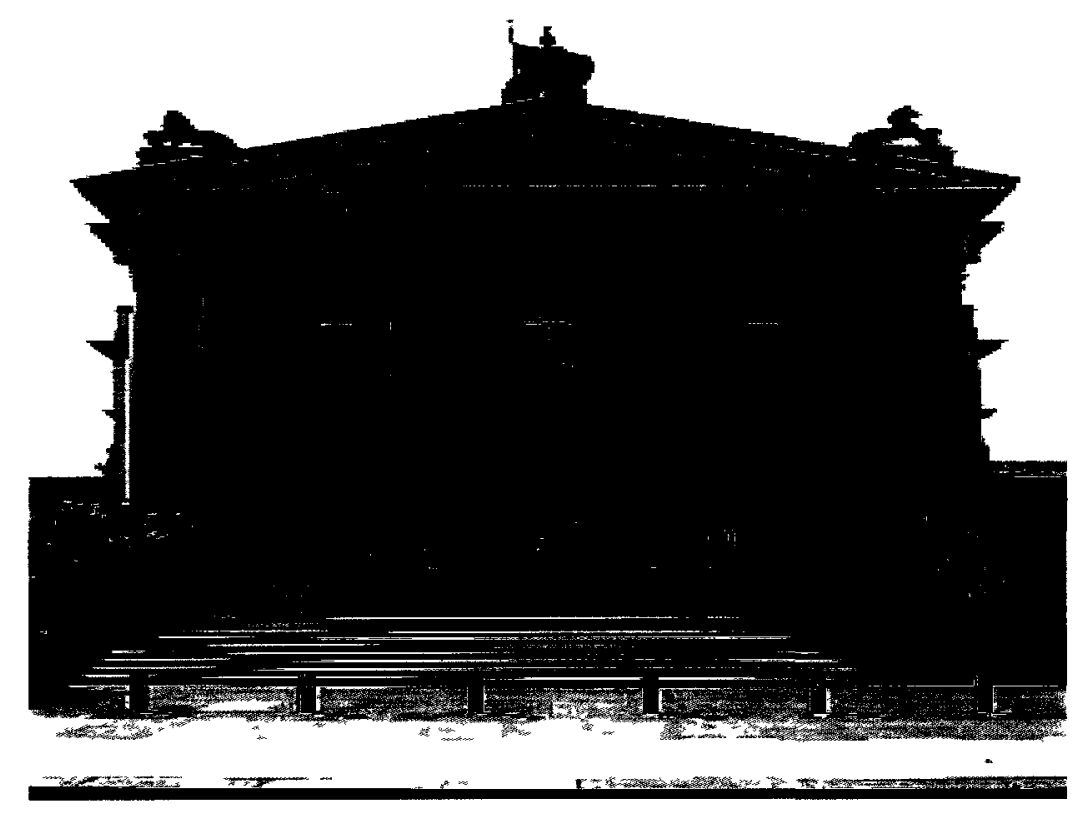

Tate Britain, London

(Photo: www.visitlondonimages/britainonview)

These early museums, mostly housed in former palaces, castles or other grand buildings, were, for the most part, sombre places that retained their airs of elitism and exclusion. They constituted shrines or temples (Cameron, in Anderson, 2004, Clarke, in Marstine, 2006 and Marstine, 2006) or sites of ritual (Duncan, 1995) and reformatories of manners (Bennett, 1995). And, despite 
some fairly acerbic attacks on them by growing numbers of modernist artists, ${ }^{27}$ it is not until the mid -twentieth century that we see a more concerted effort to make the art museum a place where all strata of society could be welcomed, Even now, I would argue that there are still many members of society who never feel comfortable inside these institutions. ${ }^{28}$

That said there have been changes. Tate Modern in London, Tate Liverpool in the North of England and the Museum of Modern Art in New York, because they appear less formal than some of the art museums housed in former palaces or castles, are all art museums that seem to welcome the active participation of people from many different walks of life.

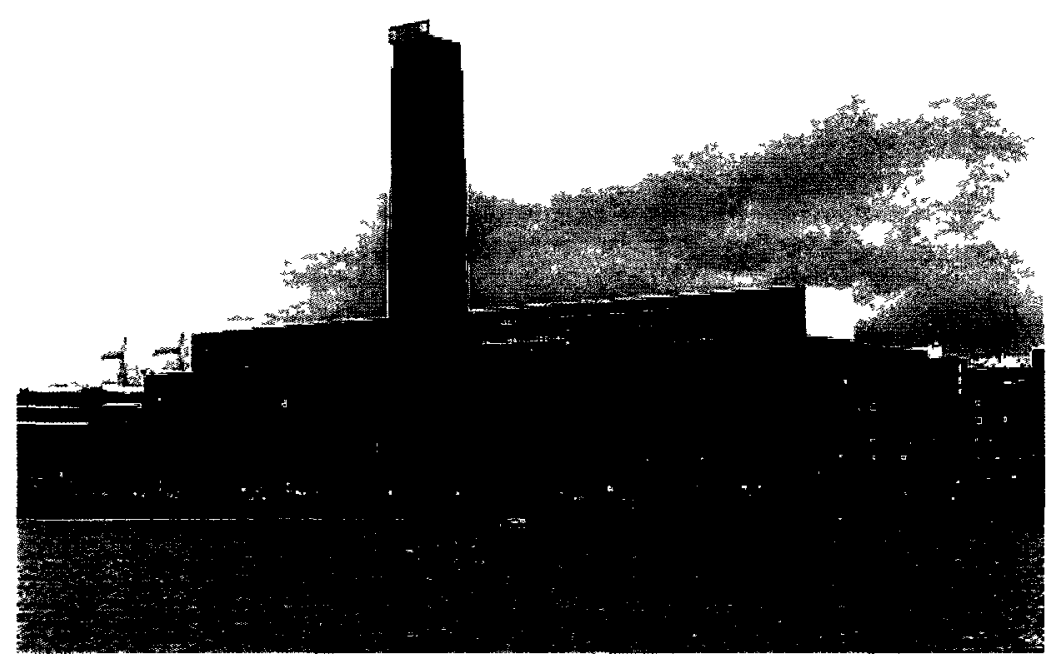

Tate Modern, London (Photo: Herzog and de Meuron 2001)

\footnotetext{
${ }^{27}$ For example, Impressionist painter Camille Pissarro called for the "demolition of these 'necropolises of art'" (Gay, 2008, p.13); leader of the Italian Futurists, Tommasso Marinetti, urged his followers to "demolish the museums, the libraries"; while Gauguin spoke scathingly of what he called "the putrid kiss of the Ecole des Beaux-Arts" (ibid.)

${ }^{28}$ For example, the homeless, the very poor, the poorly educated and other disenfranchised members of society.
} 
Tate Modern, for example, housed in the redundant Bankside Power Station on the edge of the Thames in London ${ }^{29}$ is open and light and extremely accessible with its spacious turbine hall maintaining something of its original factory-like ambiance.

\section{North America}

Most of the early public art museums in the United States were born out of the desire of wealthy Americans to add a little European sophistication to the new republic (Alexander, 1979, p. 30, Duncan, 1995, p. 48). They were meant to make "the cities of the United States more civilized, beautiful and knowledgeable, more like the cultural capitals of Europe" (Duncan, p. 54).

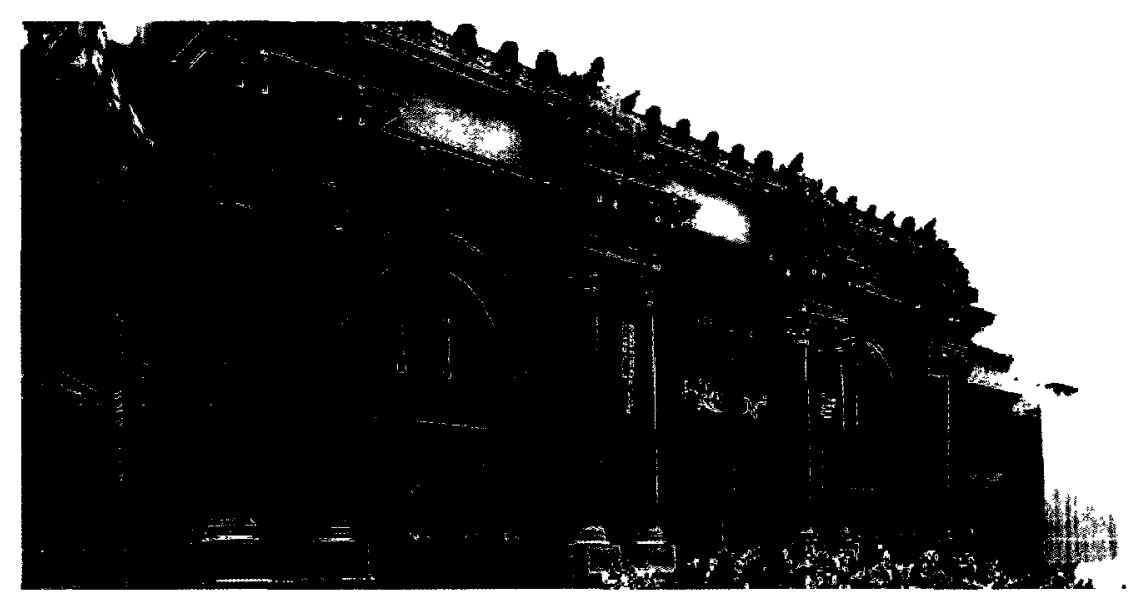

The Metropolitan Museum, New York (Photo: www.inetours.com)

In New York, The Metropolitan Museum opened in 1870 and was quickly followed by the Boston Museum of Fine Arts and the Art Institute of Chicago (Duncan, ibid. p.49). The Metropolitan, in particular, soon built up its collection

\footnotetext{
${ }^{29}$ The old power station was converted into a new art museum by Herzog and de Meuron between 1996 and 1999 and officially opened by Queen Elizabeth II on 11 May 2000.
} 
with the help of wealthy donors and, together with the Boston Museum of Fine Arts, became a model for art museums across America (Alexander, 1979, p. 31).

These new public art museums were conceived as sites of "learning and uplifting pleasure" (Duncan, 1995, p. 49). They were designed to "frame" the public they claimed to serve and dramatize "the unity of the nation" (Duncan, ibid.). To be "an effective civic symbol," the public art museum was required to "construct the visitor as an ideal bourgeois citizen"...as "a self-improving, autonomous, politically empowered (and therefore male) individual who enters the museum in search of moral and spiritual enlightenment" (ibid.).

Although not housed in palaces or castles, many of these early American museums, like their European counterparts, were (and are), nonetheless, formal and, to some extent, equally excluding (Bennett, 2003, p. 104). Near the end of the $19^{\text {th }}$ century, following the opening of many more "traditional" public art museums across the United States, however, "three progressive and influential patrons of the arts-Miss Lillie P. Bliss, Mrs. Cornelius J. Sullivan, and Mrs. John D. Rockefeller, Jr.--perceived a need to..."establish an institution devoted exclusively to modern art." Thus the Museum of Modern Art was founded in 1929. Its first director, Alfred H. Barr, Jr., intended the museum to be dedicated to "helping people understand and enjoy the visual arts of our time, and that it might provide New York with 'the greatest museum of modern art in the world"' (MoMA Website).

The public's response to this new museum at the time was overwhelmingly enthusiastic (Burt, 1977). During the next ten years, the MoMA 
moved its collections three times into progressively larger temporary quarters. In 1939 it finally moved to the building it still occupies. Barr was responsible for the MoMA's multi-departmental structure with areas committed to architecture and design, film and video, and photography, as well as to painting, sculpture, drawings, prints and illustrated books. Further expansions occurred during the 1950s and 1960s, and in 1984 a major renovation, designed by Cesar Pelli, enlarged the Museum's gallery space and enhanced visitor facilities. Between 2000 and 2006 a major renovation and expansion almost doubled the size of the original building (Burt, 1977). The MoMA has become an important centre of art in America. Its storefront appearance and easy access from the street makes it less imposing than some of the more formal "destination" museums discussed earlier.

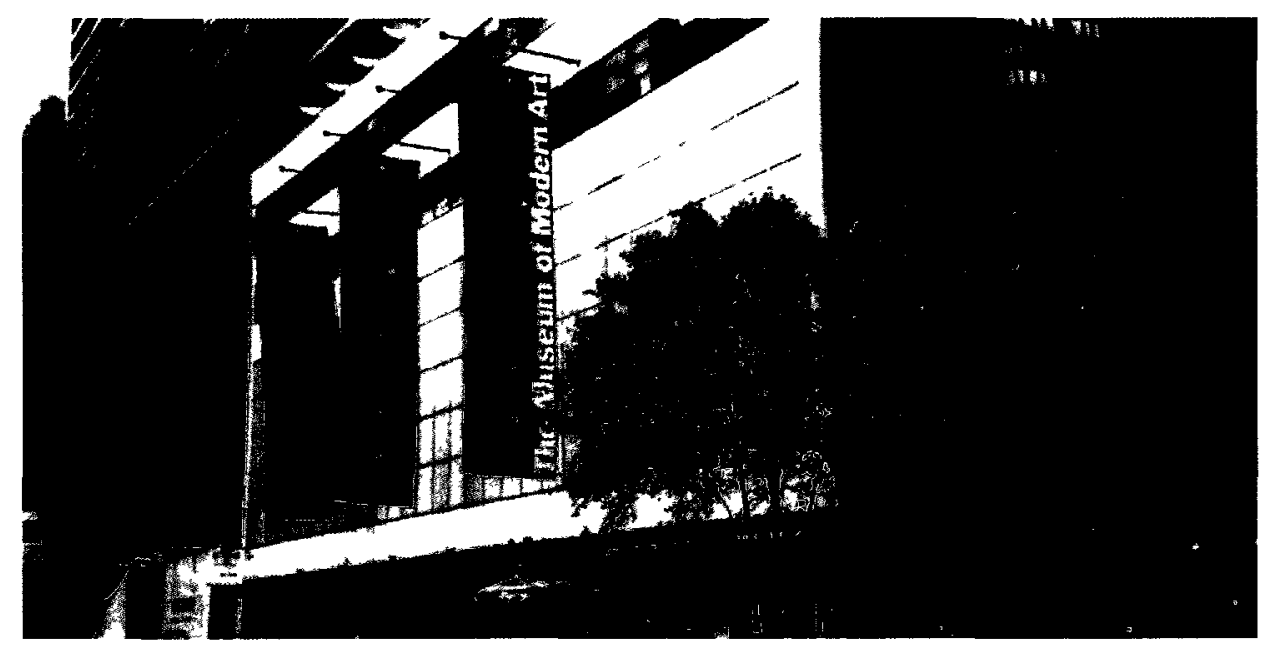

The Museum of Modern Art, New York (Photo: Google images)

In Canada, The Royal Academy of Canadian Art (later to become the National Gallery of Canada) was founded in 1880 by the then Marquis of Lorne 
and H.R.H Princess Louise during their vice-royalty and was based on the Royal Academy of Art in England (Brown, 1913, p. 173). Its objective was "to encourage the development of Canadian art through the founding of a National Gallery, the establishment of artists' schools, and the holding of annual exhibitions" (Library and Archives Canada Website). Housed in a small room at the Supreme Court of Canada in Ottawa, the RCA began holding exhibitions and growing its collection soon after its founding. Its official opening on May $27^{\text {th }}$, 1882, saw J.W.H. Watts, an employee of the Department Public Works, as its first curator and the Governor General, the Marquis of Lorne, as its first visitor (ibid.).

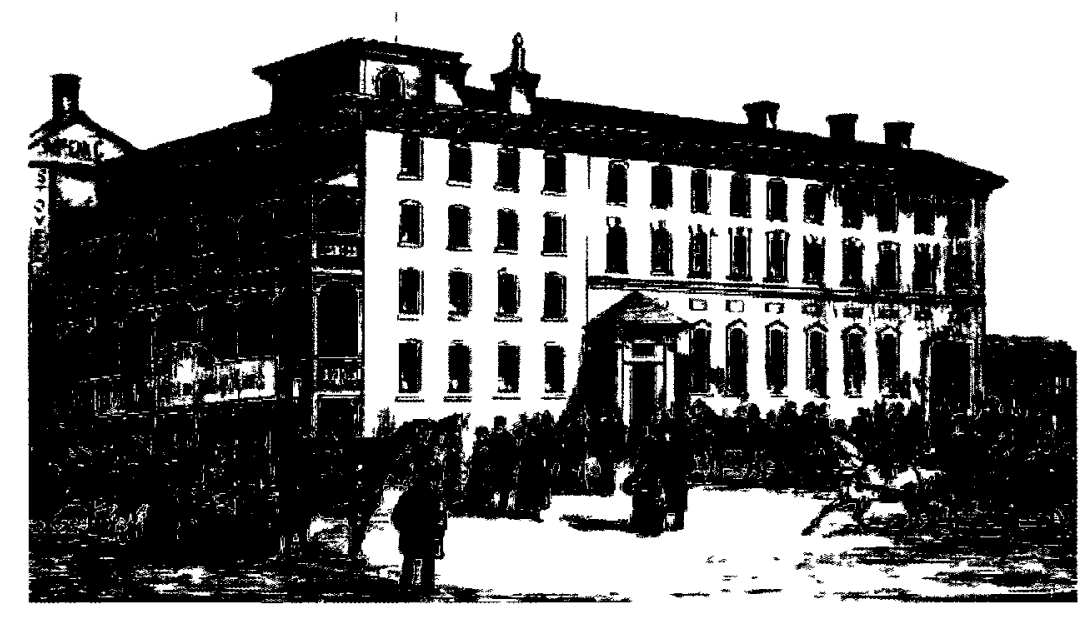

The Canadian Academy of Arts 1880 ,

(Photo: Canadian Illustrated News vol. XXI, no. 12, p. 181)

The Academy's second home was in another very small space-this time in the Department of Fisheries building on O'Connor Street. It did not become a museum proper until 1910, when Eric Brown was named its first full-time curator. In April 1912 it was moved to the east-wing of the newly constructed Victoria 
Memorial Museum on Metcalfe Street, where it was to remain until December 1959-although it had to vacate the building in 1916 to make space for meeting rooms when fire destroyed the centre block of the Parliament Buildings. It did not return until 1921 (NGC Website). In 1913, however, it was incorporated by an Act of Parliament (ibid.) to officially become the National Gallery of Canada.

The Art Museum of Toronto (eventually to become the Art Gallery of Ontario) was founded in 1900 by a group of private citizens who had formally been responsible for the 1867 founding of the Society of Canadian Artists. The Ontario Society of Artists was founded soon afterwards. Winnipeg opened its first municipal gallery in 1910 with an exhibition of Canadian art under the auspices of the Canadian Academy (ibid.). At the same time, a private art association was started in Montreal with a large collection of donated paintings. These early Canadian art establishments were intended to promote Canadian artists and Canadian art (ibid.). And, if we believe Duncan, to promote the dominant classes in Canadian society as well.

Today museums, including art museums, are appearing in cities across Europe and North America, at exponential rates (Preziosi, 2003, p. 5) as local and national governments recognise their capital potential. In many places around the world, they are clustered together within city centres. New York, for example, has a Museum Mile, Amsterdam has a Museum Square, Vienna and Utrecht each have a Museum Quarter, Rotterdam has a Museum Park, Berlin has a Museum Island and Frankfurt has a Museum Bank. The explosion of 
public art museums that started in the eighteenth century has continued well into the twentieth century and beyond. The next section examines this phenomenon.

\section{From Class Culture to Mass Culture: Social Change and the Growth of the Public Art Museum since the Late Eighteenth Century}

So what, we might ask, was the real cause of such a proliferation of art museums in Europe and North America during the eighteenth, nineteenth and twentieth centuries? Aside from collection, preservation, exhibition and scholarship, the most commonly stated purpose was once again the education and enlightenment of the "masses." That is, they were "sites of moral improvement, ideological acculturation and social distinction" (McClellan, 2008. p.7). In reality, however, these newly founded institutions were often seen as "engines of bourgeois assimilation" (ibid.). Rachel N. Klein argues that modern art institutions were "born, for the most part, as nationalist projects, committed to notions of Western superiority, cultural stability, and aesthetic hierarchy" (Klein, 2008, p. 354). In Europe, she states, the "emergence of art museums signified the transfer of cultural authority and political power from the aristocracy to the urban bourgeois public" (ibid.). In the art museum, the wealth of the collection became a display of national wealth, but now the state, and those who shaped it, not the king, became the arbiter of power (Bennett, 1995, p.38). Preziosi's argument that individuals construct their identities by looking at art becomes all too clear as the new dominant classes appropriated the public art museums for their own self-aggrandisement (Bennett, 1995, p. 27). To what degree this early 
use of public art museums carries over to the present is part of what this dissertation is seeking to discern.

The early nineteenth century had seen the beginning of widespread prosperity in Western Europe and the United States. Industrialization and the emergence of the factory-first in England and later in France, Germany Belgium, and America—was "the precondition for the mass production, and with that the mass consumption, of consumer goods including the fine arts" (Gay, 2008, p. 18). The industrial revolution, the onslaught of capitalism and the loosening of traditional values and beliefs (in the "great chain of being" and the "divine right of kings," for example), ${ }^{30}$ had changed the face of Western society. The growth of public art museums coincided with the growth of the newly wealthy bourgeoisie and the appearance of what Habermas called bourgeois public spheres (Habermas 1991). And, as these public spheres became places of power for the newly fashioned dominant classes, cultural institutions such as public art museums became exclusive spaces for their (almost exclusively male) patrons to gather-spaces that were, for the most part, unwelcoming to the increasingly gregarious masses. This is not to say that the masses were deliberately denied access—on the contrary, as Bennett has shown, early museums were designed to help educate and civilize the low-income classes (Bennett, 1995). Rather, it was, and often still is, the myths and ideologies of the art museum itself and its organizational culture that dissuaded many people from

\footnotetext{
${ }^{30}$ The "great chain of being" and the "divine right of kings" refer to the pre-Copernican belief that all power stemmed from God who was represented on earth by the king and on down through his nobles, etc. to the lowest form of being.
} 
entering. Denis Mumby in his article, "The Political Function of Narrative in Organizations" (Mumby, 1987) writes that "organizational culture originates within an organization and is conveyed to the public in the image the power system favors" (Mumby, ibid. p. $113-114$ ). Since the governing bodies of most art museums are made up of elite citizens whose public image is defined, quite often, by the technical language of art and art history, this, by default, excludes many members of society who lack the right cultural capital to feel comfortable in such environs.

This perspective is supported by Nicholas Prior, in his book, Museums and Modernity: Art Galleries and the Making of Modern Culture. ${ }^{31}$ Prior states that the founding of "public art museums represented a widely-shared moment in the social, political, and intellectual history of the European bourgeoisie" (Prior, 2002, p. 4). He argues that nineteenth-century museums served both the bourgeois quest for cultural pre-eminence and reformist goals associated with the nation state (ibid. p. 5). Drawing on Bourdieu as well as on Foucault, Prior views public art museums as places that both support the display and reproduction of social boundaries and act as discursive sites of state power (cited by Klein, op. cit., p. 355):

On the one hand, museums catered to shifts in the structure of governance, peeling away older remnants of monarchical or aristocratic grandeur and religious servitude. Through this process they were opened up to the emerging space of the nation with its origins in civil society and a

\footnotetext{
${ }^{31}$ Also reviewed by Klein op. cit.
} 
representative generality. On the other hand, art's marriage with the value of 'taste' connected the emblems of art with the struggle for a refined identity that was so crucial to the bourgeoisie's historical position

(Prior, ibid. p. 5)

Not only were early art museums used as engines of national cohesion they were also used as markers of class superiority. The fact that these early public art museums had their genesis in the castles and palaces of Europe set the scene for the notion of art appreciation as an elite and exclusionary practice. Until the eighteenth century most art—painting and sculpture, for example—had belonged to royalty or to the aristocracy, or, in some cases, to the churches. It was only natural then that as private collections became public collections the emerging bourgeoisie would appropriate these newly emerging institutions as symbols of their own elite stations in life. ${ }^{32}$ Social barriers were built into art museums from the very beginning. This is supported by observations from Bennett (1995), Duncan (1995), Marstine (2006), Cotton-Dana (in Anderson, 2004) and other theorists from my literature review.

Prior also argues that European modernity involved the "growing power of the bourgeoisie both within the state and outside," as well as the "growing independence of cultural production from the church and the courts" (ibid. p. 6). The modernization of fine arts-its entry into the market place-coincided with

\footnotetext{
${ }^{32}$ This is not to undermine the importance of some enlightened bourgeoisie in the collection of art and the expansion of art museums from the mid-nineteenth century onwards-especially their role in the collection of Modern Art and the growth of Modernism (also cited by Gay, 2008, pp.130).
} 
the "conceptual and social differentiation of artists from artisans, the celebration of artistic genius and a new emphasis on the moral connotations of aesthetic appreciation" (ibid.). Public art museums "marked the arrival of modernity by shedding aristocratic and princely forms of display, providing a rarefied space for demonstrations of bourgeois distinction" (ibid.)-even as many of the modernist artists themselves were rebelling against the "perspiring philistine" (Robert Louis Stevenson, cited by Gay, ibid. p.15). ${ }^{33}$

A similar role has been advanced by Katz for public art museums in the United States. In her book, Regionalism and Reform: Art and Class Formation in Antebellum Cincinnati (Katz, 2000), she suggests that while urban leaders in Cincinnati were initially interested in creating a common culture based on middle class ideas of refinement, they later opted for a "high" view of art and art museums that led to an elitism that excluded many of the less wealthy, less educated, classes (Katz, cited by Klein, op. cit. p. 358). Later, the Cincinnati Art Museum distanced itself from the antebellum art scene by focusing on European art-as did the Metropolitan Museum of Art and the Art Institute of Chicago. The "museum movement," Katz argues, "coincided with the consolidation and heightened confidence of the American haute bourgeoisie" (ibid.). These arguments support Duncan's notion of the art museum as a "site of ritual" (Duncan, op. cit.) and as a place where elite members of society can reconstruct their eliteness and take that eliteness back out into society. For these citizens, the art museum became a place where aesthetic experiences were moulded into

\footnotetext{
${ }^{33}$ Despite their acclaimed loathing of the bourgeoisie, many of these modern artists relied on the generosity of this newly wealthy class to fund their art-whatever their motivation.
} 
narratives that helped to define their identities and where they reinforced their sense of power in the community (Duncan, op. cit.). I maintain that these practices continue to exist in many art museums today. This belief is also supported by Preziosi's argument that people construct elite identities for themselves while looking at art (Preziosi, op. cit.).

Over the years since the founding of public art museums, then, there has been a tendency for these institutions to cater almost exclusively to the needs and desires of the elite or the educated classes-even as many of the artists themselves rebelled against such exclusionary practices. Until recently, few attempts were made to attract other strata of society—despite numerous claims for the educative and civilising nature of the museum experience. Art historians like Clarke, for example, argued against wall plaques and other informative tools that would help less informed individuals enjoy the art museum experience (Clarke, in Marstine, 2006). As the dominant classes began to appropriate the art museums, the common people were not encouraged to enter these sacred halls, despite announcements to the contrary (Bennett, 1995, p. 104).

Following the political movements of the 1960s, however, as well as the failure of modernity to fulfill all of the Enlightenment promises and the concomitant rise of neoliberalism, there have been many changes in the ways that both classes and cultures are perceived. While we might argue that the beginnings of "mass democracy, mass consumption and mass culture" were visible as early as the late eighteenth century (Stuart Hall, interview with Lawrence Grossberg, 1986, p.46), it is only over the last 40 years that institutions 
such as art museums have attempted to respond en masse to the needs of the public in general — that is to the working and lower-middle class viewer as well as to the middle- and the upper-middle class patron-with didactic panels, audiotapes, websites and other user-friendly innovations.

As public art museum professionals became more and more aware of the commercial value of attracting wider audiences—especially through the tourist industries, ${ }^{34}$ cultural theorists such as Raymond Williams (for example) were redefining the meaning of culture itself in ways that would eventually lead to completely new sets of criteria for what constituted art and other cultural artefacts (Williams, 1963, p. 311). Not only that, Williams traces the development of the class system and the production of the concept of "masses" from early thinkers such as Burke, Bentham, Blake and Coleridge through to the 1950s. The concept of the class system as we know it today, he says, was not a natural phenomenon but rather the outcome of a series of linguistic constructs beginning towards the end of the eighteenth century. ${ }^{35}$ Words like class, mass, art and culture, among others, either came into being or took on new meanings at this time and "bear witness to a general change in our characteristic ways of thinking about our common life" (Williams, 1963, p. xiii). The word "class" for example, in its modern, social, sense was first used in 1772 . First there were the lower classes, then the higher classes and then the "middling" classes. These were

\footnotetext{
${ }^{34}$ That tourists make up a large part of art museum visitors is understood. This dissertation does not examine the tourist industries per se.

${ }^{35}$ That is not to say that there have not always been social classes based on birth and wealth. What Williams is discussing is the "naming" of classes and the subsequent prejudices that have grown up as a result of that naming. As a prominent Marxist, Williams certainly understood the formation of classes as a direct outcome of the capitalist system.
} 
quickly followed in the nineteenth century by the working classes and the upper classes. Class consciousness and prejudice started to work their way into society soon after. The words upper middle class, for example, were first heard of in the late nineteenth century while the words lower middle class appeared at the beginning of the twentieth century (ibid. p. xv). According to Williams, the constant articulation ${ }^{36}$ of these class divisions caused profound schisms in society and led to a greater emphasis being put on education and the superiority of the "educated" over the merely "skilled." 37

Many educated people ... fail to notice that there are other forms of skilled, intelligent, creative activity: not only the cognitive forms of theatre, concert and picture-gallery; but a whole range of general skills, from gardening, metalwork and carpentry to active politics. The contempt for these activities, which is always latent in the highly literate, is a mark of the observers' limits, not those of the activities themselves, (ibid, p. 309)

As the twentieth century moved towards the twenty-first century, however, even more rapid changes in our social structures were taking place. As more and more people gained access to higher education the old hierarchies of class distinction began to break down. Bourdieu's habitus could no longer be relied upon to predict cultural choices. The ever-growing middle- and lower-middle

\footnotetext{
${ }^{36}$ My emphasis!

${ }^{37}$ There is a certain amount of irony in this, of course, as in Great Britain at least the "upper" classes (the aristocracy) have never cared much for education. That they send their children to exclusive schools (Eton, Harrow, etc.) is more about (to use Bourdieu's tern) cultural capital than about learning per se.
} 
classes demanded that their voices be heard. Gans' "taste cultures" and "taste publics" began to appear (Gans, 1999). They had an impact not only on cultural institutions but also on the very makeup of culture itself. Nonetheless, despite a broadening in the understanding of the meaning of culture over the last 40 years, Western societies do still discriminate, do still mark the difference between "high" and "low" culture, often dismissing the latter as "popular culture" and relegating it to the sidelines-even as it takes over as the hegemonic culture of the age. That is to say, despite the ubiquitousness of popular culture (television news programs and popular drama, popular movies, festivals, fairs, mass circulation newspapers and magazines, websites, social networks, etc.), and various attempts to close the gap between it and what is commonly known as "high art", it is still the elite events (art and aesthetics, literature, classical music, ballet, opera, theatre, film, etc.) that sit at the top of the cultural pyramid and are patronised by the "dominant classes." 38 As an interesting aside, Lynn Spigal, in her book, TV by Design: Modern Art and the Rise of Network Television, discusses the use of art on television, saying that television networks made great use of modern art in their early programming beaming it out for all Americans to see. In particular, she discusses the MoMA Television Project (Spigal, ibid. pp.144-177), and points out that, after the war, the MoMA used network television not only to promote American art, but also to promote the museum itself, not through educational programs but through programs on leisure and entertainment, reaching out to the new suburban viewer (ibid. p. 145). The practice of using art to attract visitors

\footnotetext{
${ }^{38}$ Bourdieu's definition for the elites that shape our societies
} 
was also taken up by other museums across America. The MoMA's Television Project was discontinued in the early 1960 s, however, at which time the MoMA became more interested in television as an objet d'art itself rather than as a way of attracting visitors to the museum (ibid. p. 175). Nonetheless, this was an interesting experiment in the promotion of American art and an attempt to fix the idea of art and art museums for mass audiences firmly in the American psyche, much in the same way as many art museums today are trying to reach mass audiences through the use of the internet.

Despite these attempts of the MoMA and other art museums to familiarize the American public with modern art through television, and even as they try to reach out to mass audiences today, they continue to single out elite segments of society for special privileges. The following chapters examine some of the ways in which this happens. Before that however, I examine a number of the policies, practices and pressures that have caused public art museums to change their strategies and their tactics in recent years.

\section{Government Policies, Arts Funding and the Democratization of Public Art Museums at the End of the Twentieth Century}

In November 1999 the Group for Large Local Authority Museums ${ }^{39}$ (GLLAM) in Great Britain commissioned the Research Centre for Museums and Galleries (RCMG) at the University of Leicester to undertake research into museums and social inclusion. Its October 2000 report suggested that the arts in general and museums (including art museums) in particular could be used to

\footnotetext{
${ }^{39}$ Local Authority Museums in Great Britain are those that are owned and run by local councils Museum and Society, 1(2) 75-86).
} 
help heal the wounds of social exclusion (GLLAM, 2000). These findings are supported to some extent by the articulations of Nussbaum, Deitch, Mouffe and others, cited at the beginning of this dissertation, all of whom regard art as essential to the well-being of society. The GLLAM project was just one of many initiatives put in place by "New Labour" following its election in the spring of 1997 to deal with the increasing marginalization and alienation of certain segments of British society stemming, some would say, from the many years of Thatcherism. Soon after Tony Blair became Prime Minister, for example, the government established the Social Exclusion Unit (SEU) and assembled a series of "Policy Action Teams" (PATs) to look into ways of creating a more inclusive society (SEU, 1998). The SEU's report, Bringing Britain together: a national strategy for neighbourhood renewal was presented to Parliament in September 1998 (SEU, 1998). One of its many recommendations was the use of the arts to help disenfranchised people feel more included in mainstream British society. In April 2000, the Policy Action Team 10 report, delivered to the newly formed Department of Culture, Media and Sports (DCMS), ${ }^{40}$ identified "using the arts to combat social exclusion and promote community development as one of New Labour's basic aims" (PAT 10, 200041). DCMS concurred:

Labour's fundamental belief is that the individual achieves his or her true potential within the context of a strong community ....For too long

\footnotetext{
${ }^{40}$ In1997 the Department for National Heritage became the Department of Culture, Media and Sports. Prior to this Arts and Sport had separate Ministers in separate departments (Gibson, 2008)

${ }^{41}$ The "Policy Action Team 10" report formed part of the overall SEU report, The National Strategy for Neighbourhood Renewal Policy Action Team report summaries: a compendium (April 2000)
} 
governments have considered the arts as something of a side show, an add-on to the main business in hand. The arts are not optional extras for government; they are at the very centre of our mission (DCMS 1997, in Hewitt, 2011)

Reducing the incidence of social exclusion is currently at the heart of British public policy. If cultural organisations hope to have the importance of their work recognised...they need to take account of these concerns. There is a broader practical reason however...Changing values, consumption patterns, demographics - these and other trends are constantly affecting the audiences and markets on which cultural institutions depend (Matarasso, 2002).

These reports were quickly followed with new strategies designed to address the issue of social exclusion. DCMS policy includes statements such as:

Access to the Arts can have a lasting and transforming effect on many aspects of people's lives. Research has shown involvement with the arts can increase the overall academic attainment of children, help change the behaviour of offenders and enhance community pride, amongst many other positive outcomes (DCMS Website).

It is a strategic Departmental objective to enhance access to the arts, increasing both the numbers of those taking part in and attending arts events. 
We believe that the arts can help individuals and communities by:

- bringing people together

- strengthening relationships between local residents

- welcoming differences

- removing social barriers

We work with other government departments to help them to recognize the importance of the arts. We:

- work with the Department of Health, on ways that the arts can help improve wellbeing in the UK

- work with Department for Communities and Local Government (DCLG), on using the arts to regenerate local communities

- are an active member of the Ministry of Justice's Arts Forum which uses the arts to break cycles of offending behaviour are part of the UK Borders Agency Arts and Entertainment Taskforce, which helps artists and performers from abroad to visit the United Kingdom (DCMS Website).

In addition, the then British Chancellor of the Exchequer, Gordon Brown, made it clear that all government departments (including DCMS) would be required to demonstrate that they were addressing the "value for money" issue if they were to receive funding. This included the requirements for museums across the country to show how they were working to become more inclusive 
(Selwood, 2003, p. 65). Currently, for British museums including art museums, the responsibility of combating social exclusion is driving much of their agenda.

The Department of Culture, Media and Sports is now responsible for the management of these key areas in the arts:

(a) Arts Council England: Funds Arts Council England to develop arts in England

(b) Access to the arts: Works to increase both the numbers of people taking part and those attending arts events

(c) Arts education: Supports the vital and positive role that arts education plays in the UK today.

(d) Arts \& communities: DCMS promotes the use of the arts to help individuals, communities and support social policy.

(e) Funding for the arts: DCMS funds arts in England, along with a number of other key organizations.

(f) International arts: Supports cultural exchange between the UK and other countries, as well as promoting British arts internationally.

(g) The arts industry: DCMS supports the significant contribution that the arts industry makes to the economy and our society (Gibson, 2008).

New Labour policies included free entry to the leading museums in the UK, with a mandate to increase the numbers of children visiting and to target adult visitors from low socio-economic groups (Hewitt, (2010, p. 31). However, while providing access to the arts for a wide variety of publics can be commended, these policies, brought in by the Blair government to help heal the 
social ills of Britain, sound very much like Bennett's "reformatory of manners" from the $19^{\text {th }}$ century in as much as both Blair and these early policy makers saw the museum as a place of social transformation. In addition, much of the text in the GLLAM Report seems patriarchal and condescending and Brown's comments cited earlier (i.e., that art museums would have to prove they were providing "value for money") appear to be more threatening than encouraging. That is to say, unless British (art) museums respond to the policy they will no longer receive government funding (Selwood, 2003, p. 65). ${ }^{42}$

Hewitt (2011) suggests that these policies have not been successful, arguing that "social inclusion policy functions as a form of social control; those targeted are seen as 'losers 'or 'exiles' from the industrial age who need to be 'encouraged' back into work" (ibid., p. 33). The potential of State-funded art to contribute to social change, he says, "was bound to be limited when channelled via elite art managers" (ibid.) "The public sphere can never flourish, even briefly, in a top-down administrative culture" (ibid.). If attracting more people into the art museum complex is a desired outcome, it will not be done in a manipulative way but, rather, by removing the barriers that keep some publics away.

In Canada, public museums fall under the jurisdiction of the Museums Act (Museums Act, 1990), while the Canadian Museums Association (CMA) is responsible for advocating on behalf of those same museums. In May 2006, the

\footnotetext{
${ }^{42}$ Tate receives approximately $40 \%$ of its funds from the government. The Tate Group of galleries, including Tate Modern, relies heavily on private donors, members, benefactors and corporate sponsors as well as The Arts Council of England, The Founding Corporate Partner Scheme and the British Lottery Association. Tate Modern has also received money from the Millennium Fund and the London Borough of Southwark (Tate Modern Website). Entrance to Tate Modern is free-although charges are made for special exhibitions.
} 
CMA presented Museums for Tomorrow, its recommendations to Canadian Heritage for a revision to Canada's museums policy_first developed in 1972 and partially updated in 1990 (CMA Website). These new recommendations included taking steps to ensure "increased engagement of citizens, better preservation of collections and knowledge and stabilization of museums" in order to develop "stronger communities, social cohesion, stronger understanding across regions and diverse communities and greater self-sufficiency for museums" (ibid). They called for museums to become dynamic centres of learning and connection for all Canadians as well as catalysts for participation and inclusion.

As a crown corporation, the Gallery is governed by a Board of Trustees, appointed by the Minister with the approval of the Governor-in-Council. Its Board of Trustees reports to Parliament through the Minister of Canadian Heritage and Official Languages.

The Board's mandate is to:

...develop, maintain and make known, throughout Canada and Internationally, a collection of works of art, both historic and contemporary, with special but not exclusive reference to Canada, and to further the knowledge, understanding and enjoyment of art in general among all Canadians (CMA Website).

The National Gallery achieves this mandate through a number of different activities, including "curatorial research, acquisitions and preservation, and through its outreach activities", such as: 
(a) Exhibitions and installations in the National Capital Region

(b) An extensive program of travelling exhibitions

(c) A wide range of educational and public programs

(d) Publications

(e) Marketing and communications activities (CMA Website)

Although Canadian public policy does not state categorically that the arts should be used to foster inclusiveness, the National Gallery of Canada has an extensive education and public programs policy. This policy makes it clear that one of its key objectives is to further the knowledge, understanding and enjoyment of the visual arts in Canada by:

(a) Making art in general and the collections and exhibitions of the National Gallery of Canada in particular relevant to Canadians across the country, and abroad.

(b) Encouraging "lifelong learning" about the visual arts among people of all ages and backgrounds, and at all levels of capacity, mastery and interest.

(c) Increasing public commitment and support by making the Gallery an invaluable educational resource for communities.

(d) Making the Gallery accessible to a wide and diverse audience.

(e) Enriching visitor experience and fostering collection-based learning (CMA website).

The National Gallery is also responsible for ensuring that its "public and educational programs contribute to its broader strategies, designed to maintain 
its existing audience base while expanding its reach to a younger, more diversified audience" (ibid.). That is, it has been mandated to provide a "broad range of educational activities designed to reflect multiple learning styles and levels of interest." These activities include, but are not limited to, "school-visit programs; children's programs; lectures, classes, and seminars for adults, tours, virtual programs and activities, audio programs; internship programs; outreach programs, studio programs and guides and interpreters in galleries" (ibid). These are all more or less in place at the Gallery today. The concept of the art museum as educator and moulder of social values (Bennett, 1995) remains intact. This is quite a long jump from its original stated purpose which was to "instruct" and "provide pleasure" to "connoisseurs of art" (Brown, 1913).

The National Gallery of Canada receives about $80 \%$ of its funds from the Federal Government through the Department of Heritage (NGC Website). It also receives support from the National Gallery Foundation-a group of dedicated patrons who give generously to the Gallery. The NGC also gets money from members and corporate sponsors as well as from general admission and exhibition fees and from its shop.

In the United States, government involvement in the arts is mostly managed through the National Endowment for the Arts (NEA). The NEA is an independent federal agency established by Congress in 1965 . It is the official arts organization of the United States government and is "the nation's largest annual funder of the arts, bringing great art to all 50 states, including rural areas, inner cities and military bases" (The NEA Website). The mission statement of 
the NEA says that "the National Endowment for the Arts is a public agency dedicated to supporting excellence in the arts, both new and established; bringing the arts to all Americans; and providing leadership in arts education." The NEA's vision is for a "nation in which artistic excellence is celebrated, supported and available to all Americans" (Brown, ibid.).

Another organization, the American Association of Museums (AAM) is responsible for "helping to develop standards and best practices, gathering and sharing knowledge, and providing advocacy on issues of concern to the entire museum community" (AAM Website). It is dedicated to "ensuring that museums remain a vital part of the American landscape, connecting people with the greatest achievements of the human experience, past, present and future" (ibid.). The AAM is governed by a Board of Directors comprised of a chair, a vice chair, and 18 members-at-large. All are museum professionals from institutions diverse in type, size and geographic location. The Board of Directors sets policy for the Association and is responsible for the stewardship of the fiscal resources of the Association. The mission of the AAM is to "enhance the value of museums to their communities through leadership, advocacy and service" (ibid.). Its goal is "to articulate and effectively communicate the value of museums to enhance support for the museum community" (ibid.). The AAM's strategic framework states that, among other things, museums should "provide leadership that will enhance the quality of life in American communities and ... address the growing diversity of national and local populations, recognising new audiences and community goodwill as indispensable, as well as knowledge from diverse 
experiences as enriching each institution's intellectual capacity" (ibid.). It stresses that museums must strive to increase the number of culturally and ethnically diverse museum professionals in the institution and join with their communities in celebrating the value of diversity (ibid.). Both the MoMA and the Boston Museum of Fine Arts rely heavily on private donors and corporate sponsors for support. They also receive money from their endowment funds as well as from entrance fees, exhibitions, shops and other money-making initiatives.

Museum policies in all three countries, then, have as their stated goals a requirement to attract more diverse audiences. This objective is written into their mission statements and mandates, and there is no doubt that more people are enjoying the art museum experience. Statistics show a rise in visitor attendance over the last 40 years. ${ }^{43}$ Nonetheless, as "means of communication," I argue, these institutions still have much to do before all citizens will feel comfortable within their walls.

\section{Conclusion}

This chapter has presented a brief history of art museums (as opposed to the palaces and castles that originally housed most fine art), tracing their development from the mid-eighteenth century to the present day. I have argued that public art museums were originally conceived with the beginnings of capitalism and the growth of a newly wealthy middle class-and with what Habermas refers to as the "bourgeois public sphere" (Habermas, 1991, pp. 1-5) I

\footnotetext{
${ }^{43}$ Statistics can be tracked through the annual reports of the four museums I am discussing.
} 
have discussed some of the changes that moved Western society from a class culture to a mass culture during the twentieth century and it has examined some of the government policies from Canada, Great Britain and the United States that expedited those changes vis-à-vis public art museums. I have noted that both government and public pressures are pushing for more democratic practices within the art museum world, even as art museums themselves strive to maintain a balance between attracting new publics and retaining an elite environment for their wealthy donors and benefactors and educated patrons. At the same time I have suggested that economic pressures are forcing art museums themselves to search out new audiences to help generate some of the money they need to survive. Nonetheless, I maintain that, even as they try to reach out to wider audiences, public art museums continue to create barriers that may deter some potential visitors. The following chapters show how this transpires. 


\section{Chapter Three - Attracting and Keeping Diverse Publics}

\section{Introduction}

The relationship between social distinction and participation in art museum activities is closely linked to the question of subjectivities. This relationship is important to the development of my thesis as it helps me to understand one of the ways in which art museums, in their quest for public support, tap into people's need to see themselves and their values reflected in their social institutions. An institution that speaks only to one level of society, for example, will not elicit much support from other levels of society. This knowledge is important for public art museums that have, in the past, spoken mostly to members of the elite: people with money; academics; intellectual; and the educated middle classes. In today's society (and I speak mostly of Western society), with the increasing requirement for the democratization of both our culture and our cultural institutions and the need for such institutions to generate more income, the issue becomes how can public art museums continue to attract elite patrons while opening up their doors to wider audiences? An analysis of how they operate shows a wide variety of approaches to eliciting support.

This chapter explores the ways in which the four case-study museums I have selected (The National Gallery of Canada, The Boston Museum of Fine Arts, The Museum of Modern Art in New York and Tate Modern in London) communicate to obtain and keep elite members, donors and benefactors while also striving to attract "everyday" viewers and supporters at the same time. I 
show that even though these museums go out of their way to reach diverse audiences as "means of communication," they continue to create hidden barriers that keep some publics away. The chapter begins with a discussion of member/donor benefits at the four case-study museums and continue with an analysis of their publications, lectures, films, music, family and educational programs, blockbuster exhibitions and outreach initiatives.

Research for this chapter consists of survey questionnaires, participant visits and observations of, and informal conversations with, art museum visitors as well as a semiotic and critical discourse analysis of publications and other materials found on the websites. Preziosi's claim that individuals create subjectivities for themselves while looking at art, or by extension, participating in art museum activities, is central to my investigation of why some people go to art museums, and/or become member/donor participants, and others do not.

For example, a review of the literature of any museum marketing campaign will identify the numerous benefits given to members, while a look at messages to elite donors and benefactors will uncover an entirely different range of activities with additional behind-the-scenes opportunities reserved for those who provide even more substantial monetary and/or prestigious support to the organization. An analysis of art museum publications from "intellectually focused" monthly magazines and journals to luxuriously bound coffee table books printed on expensive paper, points towards elite viewers or readers who have a high level of knowledge about art, art history, film, music and other intellectual qualities. 


\section{Members, Donors and Benefactors ${ }^{44}$}

In this section, I not only discuss the kinds of benefits given to the various patrons of the four case-study museums, but also analyse some of the messages used to attract them. I try to examine whether there are any hidden barriers stemming from the way art museums favour their various supporters. To validate my observations, I look back to some of the theories discussed in my conceptual framework.

\section{Information on Memberships and Benefits}

Information found on the four selected art museum websites shows that membership/donor advantages given to different types of patrons ${ }^{45}$ can be divided into several different categories. ${ }^{46}$ From a financial perspective, benefits range from free or reduced entry to museum events and discounts at the museum shop for basic memberships to special dinners and private viewings for elite patrons, with an entire range of benefits in between. For example, all four of the case-study museums offer basic memberships for under $\$ 100$. For this, members at the National Gallery of Canada, the Museum of Modern Art and Tate

\footnotetext{
${ }^{44}$ The difference between members, donors and benefactors rests with the amounts of money given to the museum. A basic membership usually costs from $\$ 50.00$ to $\$ 100.00$ and provides among, other things, free admission to the museum, discounts in the museum shops and restaurants, free monthly magazines and initiations to some special events. Donors usually give considerably more--between $\$ 1000.00$, for example and up to $\$ 25,000.00$ or more and receive considerably more benefits than basic members (private viewing, special dinners, receptions, etc.). Benefactors are those who donate large amounts of money or works of art, or who sponsor a new wing or building, or who "will" large amounts of money to the museum (NGC website, 2010).

${ }^{45}$ By patrons I mean anyone who supports the art museum complex.

${ }^{46}$ All information on memberships and benefits in the following pages comes from the websites of the four case-study museums and from my own survey questionnaires. My questionnaires provided data on numbers and types of events for each category but none of the museums collected information on the percentage of members, etc., who participated in special events. Copies of the completed questionnaires can be seen in Annex A. As noted earlier, data for Tate Modern came from its website.
} 
Modern receive free museum entry at all times, invitations to exhibition openings, fast track entry to exhibitions and permanent collections (no queuing), copies of the museum magazine, invitations to members' evenings and/or open houses and, at Tate Modern, access to a members' only room and at MoMA a members' restaurant. In addition, the MoMA offers its basic members four days of exclusive members' previews at new exhibitions, discounts in the museum bar, cafe and restaurant, free access to film screenings and the summer music series, discounted tickets to MoMA's public programs, including lectures, artist talks and courses, and discounts on hotels, parking and other amenities. The NGC also offers volunteer and travel opportunities, discounts on parking and half-price entry fees for guests when accompanied by a member. A basic membership at the MFA offers one year of free admission plus one $\$ 5.00$ ticket for an accompanying guest.

Family memberships, which cost between $\$ 95.00$ at the National Gallery of Canada to $\$ 175.00$ at the Boston Museum of Fine Arts, extend basic membership privileges to two family members as well as all children under 12 , with the added benefits of child-friendly programs, family-friendly events and educational programs. Once again, the MoMA at $\$ 150.00$ per family offers the most benefits including membership cards for children up to the age of 18 and an annual MoMA family festival.

Besides these basic individual and family memberships, all four museums have special patrons' programs with benefits that vary according to the level of giving. Mid-level giving at the National Gallery of Canada $(\$ 1000.00$ to 
$\$ 4999.00$ ) elicits rewards that include all the basic benefits plus additional incentives such as invitations to special events (receptions, dinners, breakfasts) special gallery-produced gifts (gallery lapel pins, posters), recognition in the National Gallery of Canada Foundation's quarterly donor newsletter, Accolade, and on the website, an invitation for two to a donor recognition reception and a behind-the-scenes tour of the Gallery.

At the MoMA and Tate Modern, mid-level donors ( $\$ 1000.00$ to $\$ 4999.00$ ) receive invitations to evening receptions for all major exhibitions, invitations to private gallery talks, complimentary exhibition catalogues (MoMA), access to members' rooms (Tate Modern), exclusive preview screenings of major films (MoMA), preferential bookings in Tate restaurants (Tate Modern), up to $20 \%$ discount in museum stores (MoMA) and credit in the Annual Review and in major exhibition catalogues (Tate Modern). At the Boston Museum of Fine Arts, midlevel donors ( $\$ 3000.00$ to $\$ 45999.00$ ) receive all the basic membership benefits plus reciprocal membership benefits at twenty-three major art museums, special programs with the curatorial staff to learn about the collections, a free MFA catalogue, invitations to patron member events, admission for 4 adults and children under 17, twelve VIP passes for all major exhibitions recognition in the Annual Report, discounts on parking, lectures, courses, concerts, films, and museum shop purchases and opportunities for travel with curators in the MFA Travel program.

Elite patrons ( $\$ 5000.00$ to $\$ 25,000.00$ and up) at these four museums receive all of the above and much, much more. They are treated to an exclusive 
array of receptions, dinners, breakfasts, private viewings, access to trustees, artist, directors, curator-led tours, installation tours (Tate Modern), visits to private art collections (MoMA), specially designed travel programs and opportunities to engage in the international arts scene (Tate Modern). At the National Gallery of Canada, donors of works of art have their names engraved on a special wall that traverses the long colonnade ramp to the "Great Hall." They are also given opportunities to schedule private tours for family and friends. ${ }^{47}$

\section{Discussion}

It seems clear, then, that all of these art museums elicit and obtain support from a wide variety of individuals by offering a vast range of benefits. For wealthy patrons there are exclusive events which not only offer them an opportunity to mix with like-minded people, but also serve as fora for constructing and re-constructing their subjectivies as elite members of the society by seeing and being seen with other elites. ${ }^{48}$ This is entirely consistent with Duncan's view, discussed in my conceptual framework, that art museums are places of ritual where, in the United States at least, elites can construct or re-construct their eliteness and then take that eliteness back out into society, and with Preziosi's belief that individuals construct elite subjectivities for themselves while looking at art (Duncan, op. cit.; Preziosi, op. cit.). For less exclusive patrons, general memberships provide a range of other benefits that offer them different degrees of opportunity to build positive self-images (Preziosi, p. 20). For example, in

\footnotetext{
${ }^{47}$ These benefits are not exhaustive; they are simply a sampling of the kinds of rewards offered to the various level donors.

${ }^{48}$ By elites I mean those people at the top of the social/cultural pyramid either through wealth or education and position.
} 
addition to eliciting members by providing benefits, art museums also entice them by selling ideas or images of subjectivity that appeal to different segments of the society. The National Gallery of Canada, for example, sells the idea of a "family of art lovers" joined from coast to coast:

Membership in the National Gallery of Canada unites Canadians from coast to coast in a community of art lovers. Members come from all ten provinces, three territories and even around the world to play an integral role in supporting Canada's collection. By becoming a Friend of the National Gallery of Canada you will join a fellowship of art lovers supporting a world-class institution (NGC Website).

As such, the National Gallery of Canada tries to attract members by selling the concept of inclusiveness (community of art lovers, family, fellowship of art lovers, etc.). Supporters of the NGC can "imagine" themselves as part of a great Canadian family all supporting the arts together. Such a view might be seen as a unifying tactic in a country divided by distances and cultures. ${ }^{49}$ it may also be a myth, since other aspects of the NGC's praxis speak specifically to a more exclusive audience. This aspect will be explored later in this chapter.

The Boston Museum of Fine Arts encourages donations through "planned giving, gifts of art and gifts for the purchases of works of art," It urges members of the public to donate money to the new MFA building (opened in 2010), to the MFA endowment fund (to support "valued programs and staff") and to its new

\footnotetext{
${ }^{49}$ Another stated role of the [art] museum is to help build national identities - that role is not explored in this thesis.
} 
auditorium—suggesting that "[n]aming a chair in honour of oneself, one's family, or another loved one, would be a wonderful way to be forever linked to the Museum" (MFA Website). Here again the museum is appealing to the emotions of would-be supporters and to their sense of uniqueness (naming a chair). Furthermore, having a chair named after one would ensure recognition among like-minded (and other) people in the society. This ties in well with Duncan's concept of art museum rituals and the construction of eliteness, as well as with Preziosi's belief in the relationship between art museums and the construction of elite subjectivities.

Neither the MoMA nor Tate Modern uses such direct ideological tactics to solicit members; instead, they rely more strictly on the benefits per se. Nonetheless, to cite both Duncan (1995) and (Preziosi, 2003) again, as well as Bennett (2002), Bourdieu (2002) and Gans (1999), the very fact of being part of the art museum experience may invoke images of elitism and specialness. What I mean by this is that, by definition, becoming a member or donor-or even just a visitor-could conjure up certain images of exclusivity regardless of the level of involvement and allow some individuals to see themselves as unique within, or distinct from, the wider society (Preziosi, 2003, ibid.). This in turn feeds the power/knowledge modalities found within the museum complex and helps to perpetuate social barriers in the community (Bennett, 2002, p. 97).

The phenomenon of art museum membership has been studied in depth by Mary-Ann Glynn, C.B. Bhattacharya and Hayagreeva Rao (Glynn et al, 1995, pp. 259 - 274). In particular, they explore people's perceptions about art 
museum membership and the frequency of use of two prominent benefits: (a) free admission to the museum in terms of the frequency of visits to the museum, and (b) invitations to special events such as openings or previews (ibid. p. 260). Glynn et al (1995) argue that while the benefits provide some explanation for the purchase of memberships, they do not offer a complete explanation, finding that less than one-fifth of the members visited the museum six or more times in a year (the number of visits required to take advantage of the free admission). They also found that the majority of museum members rarely used their special events benefits (ibid. p. 61). Elite donors, on the other hand, were more likely to frequent the exclusive events held to celebrate their generosity, which further reinforces Duncan's belief that wealthy donors often support art museums and galleries as a way of substantiating their status in the community.

Glynn et al (1995) have also looked at art museum memberships from a marketing perspective, indicating that individuals buy memberships (in general) for the privilege of "belonging," and for their need to socialize with persons of similar, class, education or demographics (Glynn et al, 1995). In their 1995 study of memberships in "prestigious" art museums (Glynn et al, 1995a) they used social identity theory to propose and test a model that "relates members' identification with (1) focal organization (2) organization and product characteristics, (3) members' affiliation characteristics and (4) members' activity characteristics" (ibid. 1995. p. 46). Their findings indicate that upper class individuals are more likely to identify with an organization if they perceive that organization to be prestigious or if they consider the benefits to be socially 
advantageous (ibid. p. 48). They argue that purchasing memberships in a prestigious organization allows people to enhance their sense of self and communicate that enhanced self to others (ibid.). They indicate that the visibility of membership may also be related to members' affiliation to the focal organization-that is, the more visible the benefits of membership are (for example having ones name published in the museum's brochures or journals or being invited to exclusive events) the more likely they are to use the organization as a means of self-definition/identification (ibid. p. 49). Finally, they argue that the more a person identifies with a particular organization, the more likely he or she is identified with a particular social group: "highly identified people are likely to purchase the category of membership that gives them organizational and public prominence" (ibid. p. 50). Glynn et al's conclusions are consistent with Duncan's (1995) theory of elites and Preziosi's (2003) belief that some individuals construct elite subjectivies for themselves while looking at art. Buying memberships or becoming donors and participating in elite art museum activities is one way that the dominant classes can maintain their roles as powerful producers of social hierarchies. My own survey questionnaire on this topic, while providing some information about members, donors and benefits, did not elicit data on participation in art museum activities as none of the four museums I surveyed collects this type of information.

\section{Conclusion}

This section of the chapter has examined the benefits offered to members, donors, and other benefactors at the four case-study art museums. I have 
highlighted the different ways in which these museums attract and keep different levels of patrons (members, donors and other types of benefactors) and have suggested that in addition to loving art and wanting to support the art museums, some people participate in the art museum experience to enhance their selfesteem and their position(s) in society. I have argued, with Glynn et al., Duncan and Preziosi, that elite or upper class members of society use art museum memberships and prestigious activities to enhance their own subjectivies within the community (Glynn, et al., 1995, 1995 a, Duncan, 1995, Preziosi, 2003). I have also suggested that by offering hierarchies of benefits, and thus hierarchies of viewers, these art museums can tap into some people's need to be seen as special and that this in turn creates barriers that help to perpetuate distinctions in society.

\section{Art Museum Publications}

This section of the chapter presents an overview of some of the publications produced and distributed by the four case-study museums as well as the publications sold in their various shops. My aim is to investigate whether or not the language, the content, the required knowledge, the cost and the visual juxtapositions speak directly to certain members of society while very possibly excluding others. That is to say, I try to discover whether the power/knowledge modalities of the art museum environment discussed earlier in this dissertation are being communicated directly or indirectly through their publications. Here again, to guide my analysis I look to Barthes, especially his semiotic analysis of the magazines Paris Match and Elle in Mythologies (Barthes, 2001). I also 
consider Jonathan Bignell's analysis of magazines in Media Semiotics (2002) and Kress and van Leeuven's discussions of newspaper layouts in Approaches to Media Discourse (2006).

\section{Magazines and Journals}

\section{Background}

The National Gallery of Canada's, Vernissage, Tate Modern's, TATE ETC. and the Boston Museum of Fine Art's, Preview, are all publications produced by the museums for their various publics. The MoMA ceased publication of its magazine, MoMA, in $2002 .^{50}$ It has been replaced with a monthly Member Calendar and an eNewsletter, This Month at MoMA, but I have nonetheless included it in my analysis. The Member Calendar and This Month at MoMA are included in the Newsletters and eCommunication section of this chapter. TATE ETC and Vernissage are free to members and for sale to the general public. Preview, the Member Calendar and This Month at MoMA are free to members but not for sale to the general public-although This Month at MoMA can be found online using a search engine.

\section{Discussion}

If a magazine is "just a collection of signs" (Bignell, 2002, p. 76), an analysis of these signs should provide an indication of their intended audiences and tell us something about those audiences at the same time. Such signs may include basic elements such as the position of the title of the magazine, the fonts used, the layout, the colours, the texture of the paper, the language, the content,

\footnotetext{
${ }^{50}$ It is unknown why MoMA ceased to publish this magazine.
} 
and so on. Each of these signs has been chosen to generate a specific meaning and send a specific message to its would-be viewers, buyers and readers. They should encode a "coherent mythic identity" for them (Bignell, 2002, p.55). That is, they should provide something for their viewers, buyers and readers to identify with or to construct an identity against. In the upcoming pages I examine some of those signs to determine if these art museum magazines speak more directly to their elite and/or well-educated members than to members with less education or wealth-thus comprising another kind of barrier that might help to keep the art museum exclusive. This said I am fully aware that most media industries target specific audiences. At the same time, if public art museums are intended to meet the needs of the population at large, as claimed by their mission statements or mandates, then their publications should be accessible to all possible audiences. ${ }^{51}$

For example, the magazine Vernissage is, according to the past director of the National Gallery of Canada, M. Pierre Théberge, "a vehicle for the National Gallery to reach out to Canadians by providing them with meaningful information about themselves, as well as their country and the world, through the visual arts" (NGC Website, September, 2006). Sponsored by Pratt and Whitney Canada, and supported by select advertising (for example, Sun Life, Heffel Fine Art Auction House, Waddington's Auction House, Enbridge Energy) Vernissage is a glossy, 30-page, full colour magazine published quarterly and distributed free to

\footnotetext{
${ }^{51}$ Laurie Ouellette raises a comparable question in her book Viewers like you: how public TV failed the people. Here she discusses public television (PBS) as a public utility and says that although it sounds as if public television is for everyone, in fact, it is limited to a rather refined (elite) audience (Ouellette, 2002).
} 
members and other donors. In 2011 , it is also sold at newsstands and in the National Gallery bookshop for $\$ 5.95$ per copy. To what degree Vernissage "reaches out to Canadians," is however, debatable. Although distributed both nationally and internationally, it has a very small annual subscription base ${ }^{52}$ Furthermore, my analysis of Vernissage, using five random but representative samples $^{53}$ of the magazine published between Winter 2006 and Winter 2010, would suggest that it does not speak to the average Canadian. My reasons for stating this are discussed below.

Tate's publication, ${ }^{54}$ TATE ETC., is published three times a year, in January, May and September. It is a 120-page, high end, glossy, art magazine/journal with a rather larger objective than either Vernissage or Preview-(the magazine of the MFA). Although TATE ETC is inspired by the Tate Galleries, it is an independent publication that "explores the visual arts scene on an international scale" (Tate Website). TATE ETC., more than any of the other museum magazines I analyze, speaks luxury—its heavy-weight, glossy stock and myriad of full-colour pictures makes it a very high-end publication. The Boston Museum of Fine Arts' magazine Preview is a much less glamorous publication than TATE ETC, or even Vernissage. Published bi-monthly, it is just for members and not available either on the website or on the magazine stand. As already mentioned, the MoMA magazine MoMA is no longer in circulation. I

\footnotetext{
52 The latest National Gallery of Canada Annual Report indicates that the annual subscription base of Vernissage is approximately 15,000 .

${ }^{53}$ My purpose in choosing these samples of the magazines was discussed earlier in this dissertation.

${ }^{54}$ Tate Modern does not have its own publication separate from Tate which includes Tate Britain, Tate Modern, Tate Liverpool and Tate St. Ives.
} 
have nonetheless included it in my research by downloading archived versions from the website.

My analysis proper begins with an examination of the four magazine covers (front matter) and continues with a discussion of the content (inside matter) in their core pages. I also review some of the advertising favoured by two of the publications. Here I draw on critical discourse analysis-especially linguistic analysis and semiotics-to help me interpret some of this information.

\section{Front Matter}

\section{Vernissage}

In all recent editions (since the Winter 2007 edition) the title of Vernissage is at the top of the cover page in large (1.5 inches) upper case, sans serif print in white on a red background with a thin black bar beneath it showing the subtitles in both English and French (The Magazine of the National Gallery of Canada / Le magazine du Musée des beaux-arts du Canada) with the issue number between them. This gives the magazine a very distinct look and makes it easily recognizable.

The right-hand corner of the title line (about two inches in length) shows the names of artists (usually three) currently being exhibited, with the name of the major exhibitor shown in bold typeface. All are set in a rectangle of a different colour from the title. The rest of the cover is given over to a sample picture from one of the exhibitions (for example, the Summer 2007 issue shows a sample from Robert Davidson, the Winter 2008 issue a sample from Joe Fafard and the Fall 2008 issue a sample from Kent Monkman). 

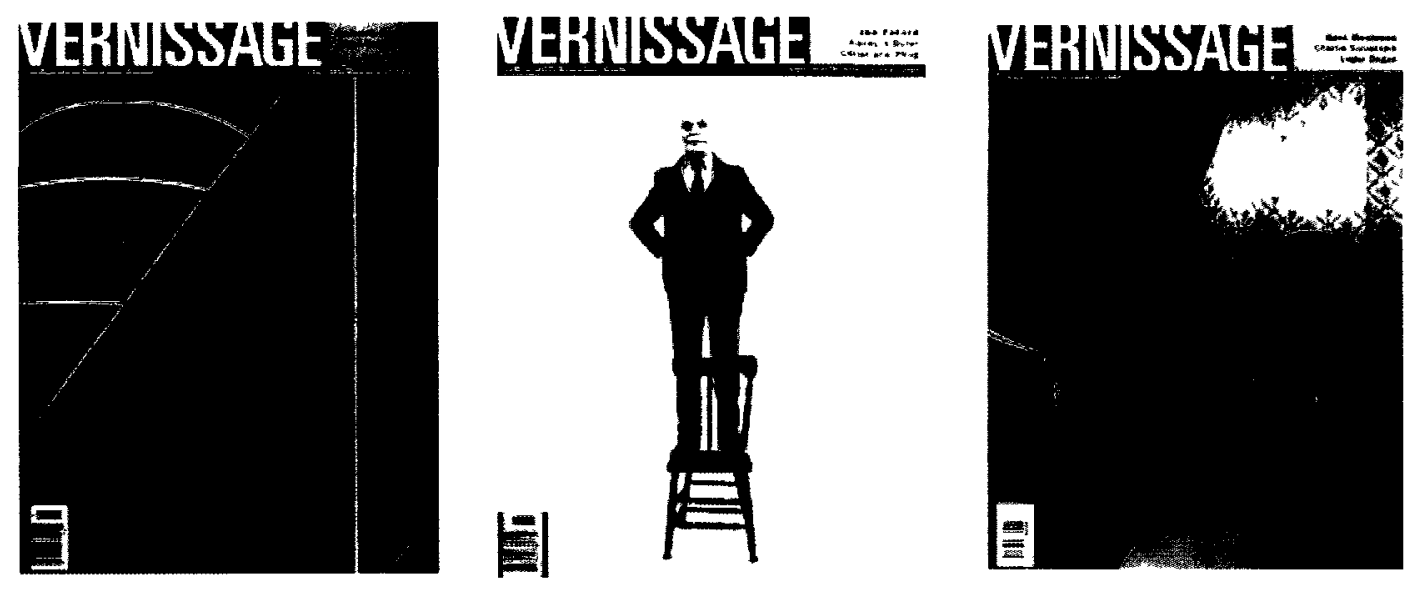

Front Covers from the NGC magazine, Vernissage

Nothing else is written on the cover. Using the Fall 2008 issue as an example, I suggest that these covers can be obscure. What I mean by this is that it is unlikely that many viewers would recognize Monkman's Boudoir de Berdashe as just a small detail from the complete installation is shown. Similarly, the cover of the Winter 2007 issue shows only a segment from Robert Davidson's nang sdang, and while Davidson's work may be more familiar to Canadians than Monkman's, there is very little to indicate which artist the image comes from. Thus I would argue that these magazines are directed at readers with a considerable amount of cultural capital. In Practices of Looking, Sturken and Cartwright argue that images are produced within the dynamics of social power and ideology (Sturken and Cartwright, op cit. p. 21). These covers of Vernissage assume a certain level of sophistication and/or knowledge of art on the part of the reader. This in itself suggests exclusiveness before the viewer/reader/buyer even opens the magazine and it points to several very specific sets of purchasers. In other words, these images on the covers of Vernissage allow "knowing" viewers to create identities for themselves that put 
them in the realm of the highly educated. They keep less knowledgeable viewers from sharing that experience. This is consistent with Bourdieu's thesis that "in the tiniest details of their morphology and their organization, museums betray their true function, which is to reinforce for some the feeling of belonging [i.e. those with cultural capital] and for others [i.e. those without cultural capital] the feeling of exclusion" (Bourdieu, 2004, op cit.). These covers of Vernissage constitute one of the hidden barriers that my thesis exposes. For the National Gallery of Canada, this could be seen as one way of maintaining its eliteness.

\section{TATE ETC.}

The cover of TATE ETC. is the quintessential opposite of Vernissage. If Vernissage is the definitive in minimalism, TATE ETC. is almost the last word in clutter. The masthead of the magazine carries the legend, "Visiting and Revisiting Art, etcetera." The top third of the page is taken up with what appears to be the full table of contents-with one writer's name, article and title running into the next, separated only by a forward slash. This plethora of black text on white is followed by a series of pictures (Summer, 2007, Summer, 2008, Autumn, 2008) or a single picture (Spring, 2007). In some issues the colors are reversed with white or coloured text on black (Autumn, 2007). Each picture is described in small black or white print. The title, TATE ETC. is superimposed somewhere between the two and is not always entirely visible. 

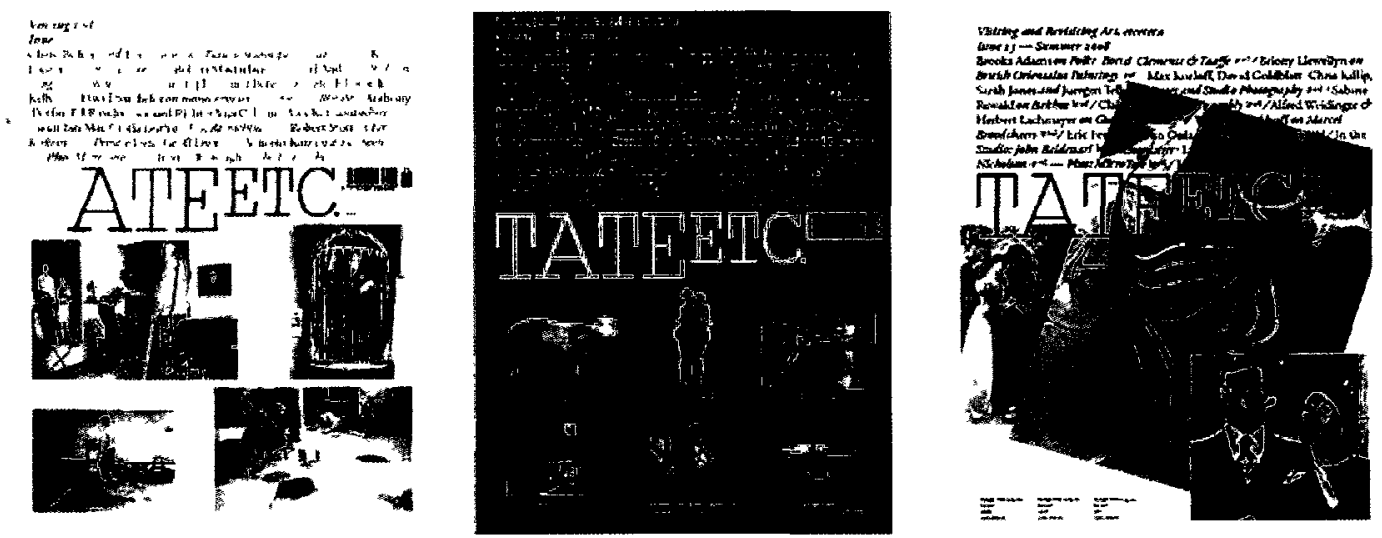

Front Covers from the Tate Magazine, TATE ETC.

Although the contents of the magazine are articulated on these covers, some of the images can still be challenging. For example, the Summer 2010 issue shows a police photograph of Lee Harvey Oswald juxtaposed beside the Head of a Young Man, circa 1500, by Lorenzo Lotto (TATE ETC, Summer, 2010). No reference is made to Oswald inside the magazine although an article titled "What Are You Looking At?" alludes to it by showing other similar pictures, including one of President Kennedy's motorcade right after the Dallas shooting; the article accompanying the Lotto picture is called: "A Visionary Projection of the Landscape of the Soul." Although not verbally linked these two images are visually linked, with the hint that it is perhaps Oswald's soul we should be looking into-or our own. In contrast, the Summer 2007 issue shows five distinctly different images from film stills (Eija-Liisa Ahtila's The House and Andy Warhol's Mrs. Warhol) to Salvador Dali bathing, to musician Caetano Veloso wearing Hélio Oiticica's PO4 Parangoné Cape 01, to a surveillance shot of a demonstrator 
outside the US Embassy in Rio de Janeiro in 1968. My point in listing these images is to show how exclusive and sometimes excluding these covers really are. The editor of TATE ETC., Simon Grant has said that he wanted to produce a magazine wherein "the idea is to show images that are unexpected, fresh and ones you would not usually see elsewhere. We are trying to create something that feels like a cross between a magazine and a journal-something readers will keep" (Frieze Magazine, June-August, 2006). However, if we believe Bourdieu and Gans these covers will not attract the uninformed reader. They are too abstract and probably too obscure to be of interest. In addition, the price of, TATE ETC. ( $£ 5.00)$ may be another barrier for some potential buyers.

\section{MOMA}

Although MoMA is no longer published, I have chosen to review one magazine from each of Spring 2000, 2001 and 2002-the three last years that MoMA was published.
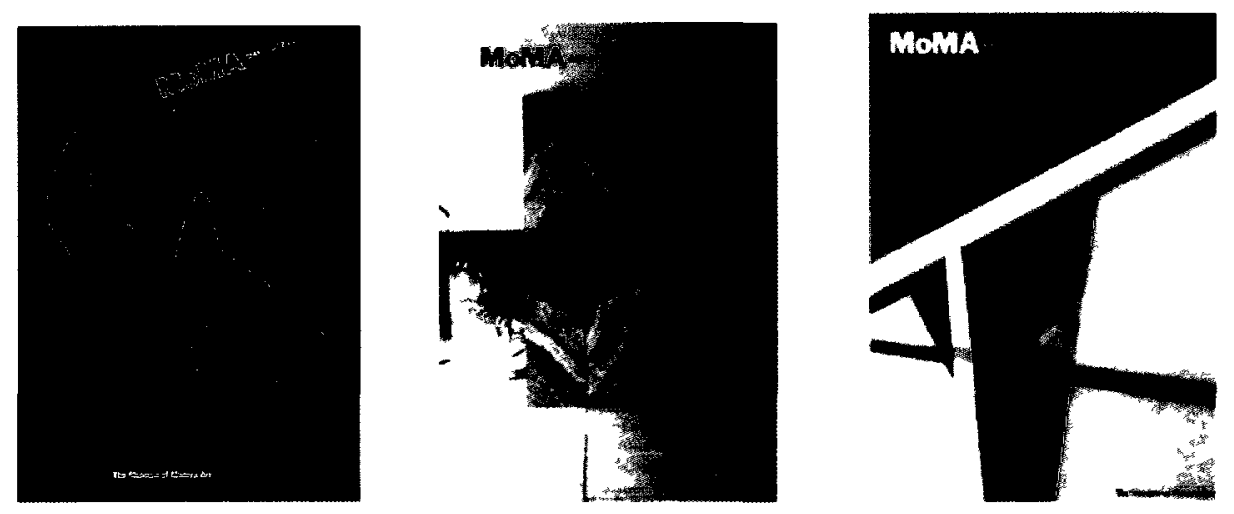

Front Covers from the former MoMA Magazine (May/June 2000, June 2001, May 2002) 
Like Vernissage and TATE ETC, the covers of these issues suggest a sophisticated and/or knowledgeable audience as no explanation, either of the cover pictures and designs themselves or of the inside matter, is provided. Their abstract and esoteric nature would almost certainly bewilder some less knowledgeable or less educated individuals (Gans, 1999).

\section{Preview}

Of the four magazines discussed here, Preview has the most traditional and most accessible cover, with mostly realistic pictures advertising a current or upcoming exhibition, and with information about the inside matter clearly articulated beside them. The name of the museum and the date of the issue are positioned close to the top edge of the magazine and are clearly visible to the reader.
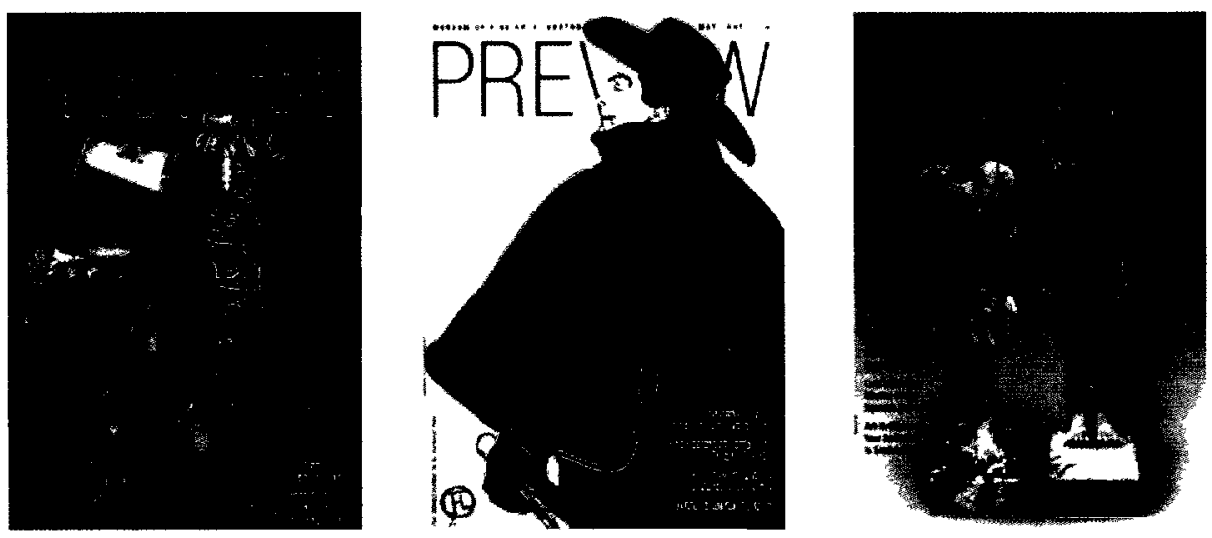

Front Covers from the MFA Magazine, Preview 2010

Since the images on the cover of Preview (see below) are more "realist" than those on any of the other magazine covers it is likely lif we believe Bourdieu and Gans) that they would appeal to a greater number of publics than the covers of 
the other three magazines. That said, I would argue that since Preview is only available to members of the MFA, the museum is dealing with a captive audience and does not have to concern itself with general subscriptions or casual buyers. All samples of Preview are from 2010.

\section{Inside Matter (Content)}

\section{Vernissage}

The first article inside Vernissage-after the table of contents and some high-end advertising (discussed later)—is always the "Director's Notebook." This usually includes a short introduction to the current temporary exhibition(s), a discussion of some of the new initiatives happening at the Gallery and other more general announcements. Next comes "Affairs of Note", a one-page mixedbag with titles such as: "Silver Fit for a King" about King Carl XVI and Queen Silvia of Sweden's visit to the Gallery to view a new exhibition, Five Centuries of Swedish Silver (Winter, 2007), "Fafard in the Foundry Online" about the filming, by a Regina film crew, of Joe Fafard at work in his bronze foundry in Pense, Saskatchewan or "Art Out Loud" about "[h]ip and connected young adults getting their social and collective juices flowing at Artsparks" (Winter, 2008). These pieces are fairly short but the level of language and specialist knowledge needed to understand them-with references to "German lavishness, the French Baroque, Minimalism and Neoclassicism" (Winter, 2007), for example-may be difficult for some potential publics. Like the front matter, they speak to select audiences. 
The bulk of the magazine is given over to serious articles about the artists and the exhibitions currently showing at the Gallery. For example, during the Renoir exhibition of 2007, the concurrent Vernissage featured an article entitled, "Experiments in Landscape: Renoir's Abiding Passion," the Winter 2007 edition included an article, "Beyond the Formline: Davidson's Abstract Edge" as well as "Henri Cartier Bresson: Image Hunter and Unbidden," an article on Jin-me-Yoon. Even though artists such as Renoir, and Davidson would be familiar to most Canadians, I suggest that these articles may be too theoretical and too academic to appeal to the average reader. Words or expressions like "Abiding Passion," "Abstract Edge" and "Unbidden" are not, I would argue, part of the average person's vocabulary. One article in the Fall 2008 issue, "In on the Act," asks readers to "suspend their traditional expectations of the ocular, object-centred gallery experience and return to a state of childhood discovery through play" (Vernissage, Fall, 2008, p. 9). That same article states that the works in the collection are rooted in $20^{\text {th }}$-century "histories of performance, installation, environmental, minimal and body art" which "foreground the interaction between art object and viewing subject" (ibid). We also learn that another work in the collection "engages the viewer's body as an essential canvass for creating sculptural meaning" (ibid. p. 9). My point here is that these are not concepts that many potential publics would relate to. And if we believe, with Barthes, that the reader is not only the "consumer" of the text but also its "producer" (Barthes,1974), then we might agree that readers of these texts would need a considerable amount of cultural capital to make sense of the metaphors or 
understand the references in this magazine. This is not to say that I think the NGC is wrong to produce a magazine such as Vernissage, but merely to point out that this is one more way in which it speaks to its well-educated, wellinformed audiences, and one more possible barrier to inclusion for others.

\section{TATE ETC}

From "essays to interviews, from ancient Tate archives to cutting edge studio work, TATE ETC. explores art context, history and meaning." Within these boundaries, it blends "the historic, the modern and the contemporary to show that art does not exist in a vacuum, but is rooted in many traditions" (Tate Website). That said, TATE ETC. usually begins each issue with commentaries on current exhibitions and works outwards from there towards a broader art-world perspective. Its articles, accompanied by a series of glossy, craftily juxtaposed, brightly coloured pictures constitute serious art criticism. The Summer 2007 issue begins with an essay on "Interiors" that covers the work of (among others) Gregor Schneider, Richard Billingham, Jan Vermeer, Andrea Zittal, Henri Matisse and Pieter de Hooch, who, with the exception of Matisse and Vermeer, may not be household names. This same issue also includes two essays on "Dali and Film," one essay on Andy Warhol and three essays on the Brazilian modernist painter, Hélio Oiticica. Apart from the obscureness of some of these artists, the level of language used in this publication can be extremely sophisticated, rendering it, I would suggest, impenetrable to some segments of the population. For example, speaking of Pierre Huyghe in the Summer 2006 issue, the writer Nicolas Bourriaud says "the multifariousness [of his work] is a corollary of his 
refusal of that contemporary media practice of taking the place of the other in order to speak in his name - a kind of ventriloquism" (TATE ETC., Summer 2006, p. 82). Like Vernissage, TATE ETC. speaks to exclusive and knowledgeable audiences, allowing them to create elite identities for themselves by participating in the myth of intellectual superiority (Barthes, ibid. 1972). In doing so, it also helps to perpetuate both the myth and the reality of the art museum as a place of exclusivity (Bourdieu, Gans, etc., op. cit.).

\section{MOMA}

Like Vernissage and TATE ETC., MoMA begins with a note from the Director. It provides sundry information on comings and goings at the museum, and on new exhibitions and film programs. The rest of the inside matter consists of serious articles on art, artists and art history, as well as interviews and discussions. For example, the February 2000 issue contains an article entitled "Changing Visions: French Landscapes" which tells readers that Eugene Atget's "photographs of Paris and its environs" constituted "a record of a whole environment en passent." It argues that "[a]s a medium, photography allowed artists to capture ... the enduring topographical specificity of a particular site and its evanescent quality at any one moment" (Dabrowski, February 2002, p. 4) The May/June 2000 issue includes "Kahn's Modern Monuments" and lets the reader know that, for Kahn, "the eternal human desire for meaningful interaction and communication transcended the secular or religious nature of an architectural project," adding that, "Khan's quintessentially monumental and symbolic architecture embodied idealism and powerful inspirations evoked by 
archetypal geometry—symbols of the tectonic bond underlying all human community" (Reed, May/June 2000, pp. 12-13). October 2001has, "Capturing Giacometti's Gaze" (Umland, October, 2001, pp. 2-7), and "When Art Comes to Life" in which the reader learns that "[t]he real, the imagined and the inanimate are cohorts in the illusionary worlds of animation (Porter, October 2001, p.12). These titles and articles target readers with high levels of education or knowledge of art history. As both Bourdieu (2002) and Gans (1999) have pointed out, they are unlikely to appeal to less experienced readers.

\section{Preview}

Inside its front cover Preview has a "Just for members" column—which is somewhat redundant since the entire magazine is just for members-and a letter from a senior official of the Museum. The January/February 2010 issue of the magazine has a message from the Ann and Graham Gund Director discussing improvements to the museum and the new parking area and announcing the new exhibitions, Tomb 10A, Albrecht Durer, paintings from the Moulin Rouge era and Luis Melendez: Master of the Spanish Still Life. This is accompanied by a picture of the director himself, and followed by full-page pictures and articles on the current exhibitions, including those mentioned above. It also includes a onepage Calendar of Events with pictures and six pages of detail on activities at the Museum during January and February. The final page has information about new trustees, about the Museum School, about dining at the museum and about the bookstore and shop. The last page is reserved for contact information and other general information. The back cover provides another list of "what's on" at 
the Museum. Despite its traditional cover and promise of straightforward information, Preview is very much an insiders' magazine, which is, of course, consistent with its intent-to be a source of information for those already committed to the MFA.

\section{Advertising}

Magazine advertising, whether linguistic, aural or visual, speaks to a specific audience with a view to selling a product, a service or an idea. Bignell, however, drawing on Barthes, suggests that more than simply selling, the purpose of (magazine) advertising is to ask us, the reader/viewer/buyer, to "participate in ideological ways of seeing ourselves in the world" (Bignell, op cit. p. 31). "Ads," he says, "make use of signs, codes and social myths already in circulation" (ibid.). They "endow products with a certain social significance so that they can function in our real social world as indexical signs of the buyer's good taste, trendiness or some other ideologically valued quality" (ibid. p. 36). That is to say, advertisements give meaning to buyers and allow them to create mythic identities; they also represent them. What I mean by this is that in order for an advertisement to work, buyers must either be able to find themselves in that advertisement or find an identity they are striving for. This section of my chapter looks at the advertisements in Vernissage and TATE ETC. ${ }^{55}$ to determine which publics they address and what messages they send.

\footnotetext{
${ }^{55}$ Advertising from MoMA was not available; there is no advertising per se in Preview
} 


\section{Vernissage}

Advertisers in Vernissage are few. They include Pratt and Whitney Canada, Heffel's Fine Arts Auction House, Enbridge and Waddington's Auction House-all exclusive companies offering goods of little interest to the average Canadian. For example, in the Winter 2007 issue, Pratt and Whitney shows part of a jet engine with the words "Imagination powering art" beside it, Waddington's offers a Lawren Harris for sale at $\$ 2.42$ million, a piece of soapstone at $\$ 280,000$ and a gold and silver broach at $\$ 295,750$. In the Fall 2008 issue, Heffel's Fine Art Auction House shows an Alexander Colville recently sold for $\$ 690,000$. I would argue that these advertisements, the mythic signs they represent, and the identities they allow individuals to construct, are well beyond the imagination of most publics in our communities. Rather, they appear to speak to a small, select group within Canadian society. Thus, M. Théberge's comment, quoted earlier, that Vernissage is "a vehicle for the National Gallery to reach out to Canadians by providing them with meaningful information about themselves...their country and the world..." is unconvincing.

\section{TATE ETC.}

The first 30-plus pages of TATE ETC. are given over to advertising ${ }^{56}$. From high end hotels (London Park Lane, InterContinental) to exclusive resorts where the beaches are "works of art" (Government of Catalonia) to privately

${ }^{56}$ Despite this, according to Simon Grant, editor of TATE ETC., "the content of the magazine is not connected to, or shaped by, advertisers. As a not-for-profit magazine, TATE ETC. exists outside the commercial sector..." (Frieze Magazine, 100, June-August 2006, online). That said, art and other luxury magazines are filled with advertisements for lavish goods Bourdieu, 2002, pp. 278-280). 
escorted tours (Hebridean International Cruises) to exclusive galleries (Ben Brown Fine Arts), and luxury goods (BMW, Hermes) this magazine targets the wealthy and the worldly. Many other advertisements in TATE ETC. announce private exhibitions not only in London but also in New York, Tokyo, Hong Kong and Hamburg (to name a few). It recreates a world that elite members of society are already a part of, and perhaps it allows others to dream. Many of the images are abstract and difficult to interpret. The BMW ad on the inside covers of a 2006 issue, for example, shows only a small section of a brake light. The caption that accompanies it says, "It's only a light ..." “... it may be the only type of light that improves the reactions of the driver behind you." That the BMW is an elite car is already well known; that the driver following such a car may need to brake quickly implies fast driving and fast (elite/trendy) living.

The Hermes ad in the same issue shows a single watch with the caption "An Hermes Watch has Time on its Side." This too implies leisure and luxuryand time to visit art exhibitions all over the world. These ads are elitist and exclusionary, sending a message that art and many things related to art are not for the average citizen. The advertising in both Vernissage and TATE ETC speaks to high amounts of cultural (and other) capital. It is another sign that these art museum publications are speaking to some very elite publics

\section{MOMA}

Because this magazine is only available article by article through JSTOR (electronic journal storage), it is not possible to review the advertising. This limits 
my research in this section as I cannot include the MoMA in this part of my analysis.

\section{Preview}

There are no glossy advertisements in the MFA's Preview, creating another limitation to my research in this area. However, the MFA Membership Program is sponsored by American Airlines, 90.9 wbur and masscultural.org (Preview January/ February 2010, p.17) all of whom are recognized in the magazine.

\section{Brochures and Catalogues}

All four of the case-study museums produce colourful brochures that announce exhibitions and other activities held in their establishments. These are available at the museums. They are also mailed to donors and members and provide a wealth of information in relatively straightforward language. Tate, for example, is published bi-monthly and provides details of all current exhibitions and displays as well as events (films, talks, symposia, courses and workshops, etc.) and other activities, not just for Tate Modern but for Tate Britain, Tate Liverpool and Tate St. Ives as well. It is filled with brightly coloured pictures from all the exhibitions; its advertising is more modest than that found in TATE ETC. (Premium British Lager, for example, and Guaranty Trust Bank, April/May, 2010). It is more accessible than TATE ETC., but, nonetheless, requires a quite a lot of cultural capital. It appears to speak most directly to the educated middle classes

Exhibition catalogues are usually more substantial; they are often (but not always) opulent and expensive-too expensive, I would argue, for some publics. 
For example, the NGC's catalogue for the Thomas Nozkowsky exhibition held in the summer of 2009 is a beautifully bound, hardcover book filled with full-colour prints of Nozkowsky's paintings and a generous introduction by Marc Mayer, the curator of the exhibition and Director of the NGC. The cost of this catalogue is $\$ 60.00$. Similarly, the cost of the Renoir catalogue, Renoir Landscapes, with essays by co-curators, Colin B. Bailey and Christopher Riopelle, as well as by other art history specialists, and published, in hardcover with lavish pictures, by the National Gallery in London, England costs $\$ 80.00$. The Morrisseau catalogue costs $\$ 50.00$.
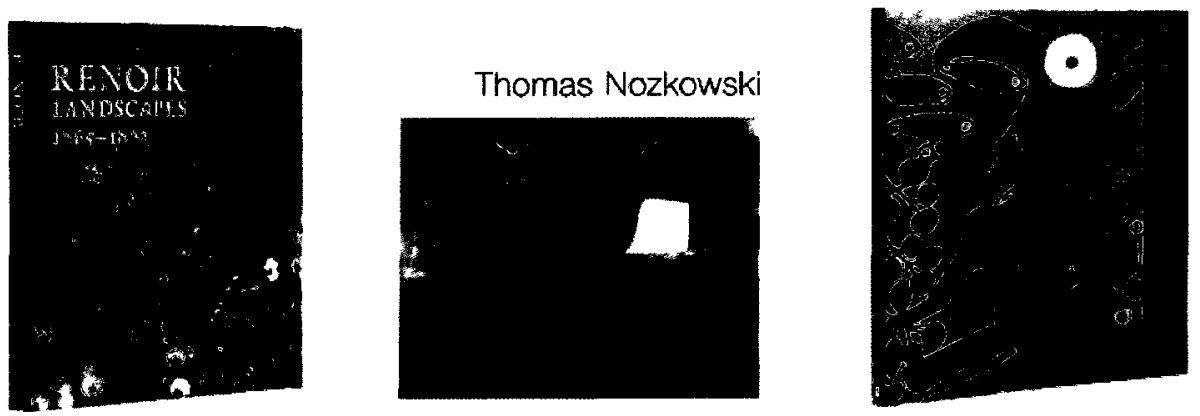

Catalogues from recent exhibitions at the MoMA, the MFA and Tate Modern exhibit the same degree of opulence and are similarly priced. The samples below are from other recent exhibitions at the aforementioned museums.
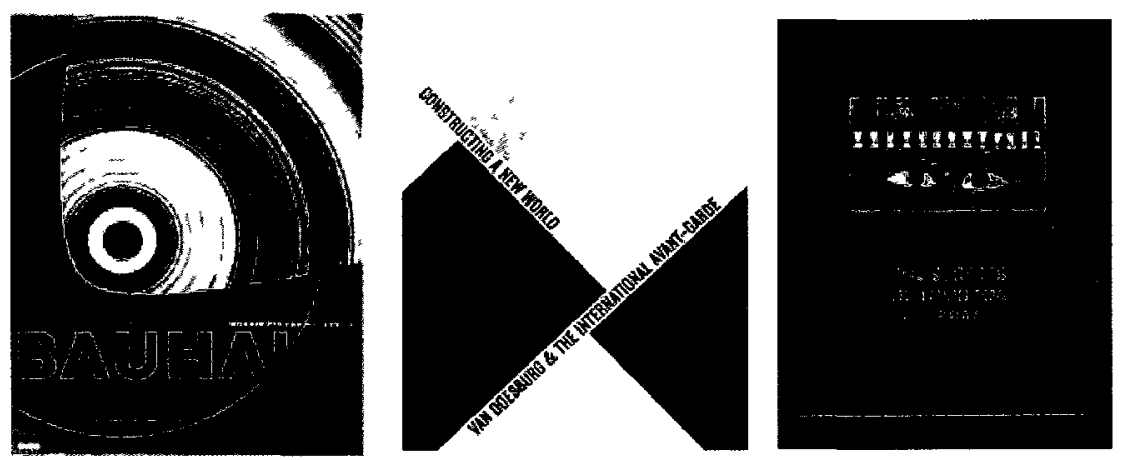
In addition to being expensive, these catalogues are too cumbersome to be useful during an exhibition. The catalogue for the 1984 Primitivism in $20^{\text {th }}$ Century Art exhibition at the MoMA, for example, was published in two volumes and ran to 700 pages, more suitable to be taken away and displayed at home than used as guides to the exhibition. This suggests a somewhat wealthy and sophisticated buyer-and, although in some cases less expensive paperback editions are published concurrently with hard cover editions, they may still be too costly for large numbers of people. These are elitist publications for elitist patrons, signifying another way that the art museum targets its rich and/or educated visitors, subtly communicating messages of exclusion to less sophisticated visitors. That said we should be cognizant that copyright prohibitions may prevent the reproduction of many of these books at lower prices.

\section{Newsletters and e-Communication}

The National Gallery of Canada, MoMA and Tate Modern all produce monthly newsletters and/or e-communication documents. The MFA sends a regular e-communication to its members. The NGC's e-newsletter announces current and future exhibitions. Hyperlinks provide detailed information for families (Artissimo, Tiny Tots, Esso Family Fun days) teens (Off-the wall art workshops) and adults (meet the artist, meet the curator, mini-talks and lectures). MoMA's Member Calendar is a 60-page, four-inch by eight-inch brochure-like publication that includes information on new exhibitions, ongoing exhibitions, the 
annual fund, museum programs and the MoMA store among other things. It is published entirely in black and white with the exception of small amounts of orange text (the MoMA colour) on its cover and table of contents. The text provides detailed descriptions and commentaries on events at the museum. It is mailed to members every month. The MoMA also sends e-communications to members on a regular basis. Unlike its fore-runner, MoMA magazine, this publication appears to be more accessible to a wider audience.

Tate's e-communication includes six different bulletins from: Tate Contemporary, Tate Research, Tate Families, Tate Events and Courses, Young Tate and Tate Shopping. These are sent to members by email at regular intervals. Here we see examples of these museums reaching out not only to their wealthy patrons but also to their members at large. Nonetheless, these publications are not available at newsstands or at tourist information centres, so they are not readily available to the general public.

\section{Lectures, Films and Music}

All four of the case-study museums offer a variety of extracurricular activities such as lectures, films and music. For the most part, these are aimed at individuals with a relatively high level of education and knowledge of art and/or art history. The National Gallery of Canada, for example, offers lectures in conjunction with specific exhibitions and collections as well as special talks by the curators of each exhibition and, at times, "meet the artist" sessions. It also offers a 45 minute thematic introduction to various artworks. The Gallery offers a Sunday Painters program that encourages participants to learn from the Gallery's 
collection and then return to the studio to create their own artworks. And, it has guided tours and in-the-studio workshops for adults with special needs.

The Boston Museum of Fine Arts offers a lecture series related to special exhibitions and a celebrity lecture series featuring a range of "impressive and inspiring speakers", as well as lectures on art and culture which include such topics as: "Architecture and its Cultural Significance in India," "Forays into Middle Kingdom" and "Shigera Ban: Works and Humanitarian Activities." Courses on art and culture at the MFA include "Looking in Depth at Egypt's Classical Age, "History of Film from Silent Movies to Social Networking and "The Tibetan Mandala: Culture and Religion on the Roof of the World." The MFA's Looking Together: Gallery Discussion courses explore its collections in small groups with instructors who encourage questions and discussions. These courses take place in the galleries and are intended to help people develop their viewing skills as well as their knowledge of the artworks. The Looking Together courses include titles such as "Impressionism and Post-Impressionism," "Close Encounters with European Paintings," "What is Classical: The Art of Greece and Rome" and "Deconstructing a Still Life." Thus, if we look back to Sturken and Cartwright (1994), we might say that "looking" in this instance becomes very much about knowledge and power.

Lectures at the Museum of Modern Art during Winter 2010 included, "The Erotic Object: Surrealist Sculpture from the Collection"; "Women Artists at the Bauhaus"; "Pablo Picasso through the Years" and "The Changing Face of Sculpture," while Tate Modern offered "Revealing Culture Head On: Tanya 
Raabe"; "Michael Radkowitz: Artist's Talk" "Aesthetics: Classic Aesthetics: An Introduction to the Philosophy of Art"; "Stillness and Movement" and "Law and Art: Challenging the boundaries between the legal, the just, the ethical and the aesthetic," among other things, over the same period. In addition to lectures, talks, courses and workshops, all four museums offer a variety of films throughout the year. While these lectures are advertised as being for the general public the titles themselves may, if we believe Bourdieu, appeal mostly to the intellectual class; that is, those with high amounts of cultural capital (Bourdieu, 2002, p.287).

The National Gallery of Canada began its 2010 film season with Before Winter a 2008 winner at the Toronto film festival and winner of the "Citytv prize" "for its arresting beauty, its humanist, innovative storytelling and its artistic integrity in capturing the narrative of a people through an intimate tale" (NGC Website, January 2010). The MFA brought its viewers The Boston Festival of Films from Iran as well as In Search of Beethoven and a New Mexican film I'm Gonna Explode. The MoMA offered a documentary fortnight between February 17 and March 3 (Documentary Fortnight: MoMA's International Festival of Nonfiction Film) as well as its renowned New Directors/New Films festival at the end of March/beginning of April. It also offered a year-long festival of Frederick Wiseman's films. Tate screened Invocation and Evocations: Queer and Surreal, Harun Farock: Videograms of a Revolution; Paul McCartney, Kenneth Anger and Steina; and Woody Vasulka: Latent Perceptions, among other films in January/February 2010. 
My point in listing all these films is to show that they are not just straightforward films about art. They are more like titles we would expect to see on an exclusive film society program-and, of course, that is what these art museum film programs are-exclusive activities for the intellectual elite. Using the word "film" instead of "cinema" or "movie" communicates something about the content and the venue and sends a message (a sign) that this, once again, may not be for the average citizen, but, rather, for the well-educated viewer. The word "film" has a more intellectual connotation than the word "movie"-especially in North America. ${ }^{57}$ And, if we apply Barthes' concept of the text ${ }^{58}$ as a "galaxy of signifiers" to be interpreted by the reader/viewer, then only those individuals with the right social, cultural and educational background will have the cultural capital to enjoy these films (Barthes, 1974, p. 5). What I mean by this is that unless one has the knowledge and the experience to recognize and interpret the signs and signifiers in these films it may be difficult to enjoy them.

Music is also an integral part of each museum's activities. The National Gallery of Canada initiated its Music for a Sunday Afternoon program $^{59}$, beginning in 2010 with a one-hour concert by Acacia Lyra - Harp and Voice Duo and followed closely by Pinchas Zukerman on the violin and Jan Lisiecki on the piano with ensembles of the National Arts Centre Orchestra. The MFA has its own trio playing harpsichord, viola da gamba and baroque violin. The 2010 program Marin Marais' La Sonnerie de Ste. Geneviève du Mont-de-Paris, and La

\footnotetext{
${ }^{57}$ The word "movie" is not heard as frequently in Europe, where individuals are more likely to speak of seeing a film or going to the cinema.

${ }^{58}$ Here I consider a film to be a text.

${ }^{59}$ The NGC also has a full program of events in French, including La musique au Musée
} 
Gamme, Préludes from Couperin's L'Art de Toucher le Clavecin, and sonata for violin, viola da gamba and continuo by Leclair, is followed by Songs of Sondheim, Gershwin, and others and then by music of the Spanish baroque (MFA Website, January 2010).

Neither MoMA nor Tate Modern offered music programs per se during the winter of 2010. Tate Modern, however, offers ongoing musical performances and other special events that provide new interpretations of the exhibitions and displays showing at the museum (Tate Modern Website). Looking back again to the work of Gans, as well as to studies on music and class by North and Hargreaves, ${ }^{60}$ it seems that as with film and many other activities, the music offerings at these museums are designed to target the intellectual elite. Member/donor benefits, high-end magazines and journals, lectures, avantguard/art films and high-culture music, then, are just some of the ways that art museums continue to construct barriers that send messages of exclusion that may work to keep many of their lower-class, less educated, less privileged publics away.

\section{Family/Children's Programs}

Family and children's programs at the NGC, MFA, MoMA and Tate Modern come in a variety of shapes and sizes and are an integral part of their offerings. The National Gallery of Canada is especially rich in its offerings for children and teens. Beginning with its "Tiny Tots" program which promises "[f]un-

\footnotetext{
${ }^{60}$ North and Hargreaves studied the relationship between music and lifestyle preferences and found that a "liking for 'high-art' music was indicative of a lifestyle of the upper-middle and upper classes, whereas liking for 'low-art' music was indicative of a lifestyle of the lower-middle and "lower" classes" (North and Hargreaves, 2007)
} 
filled activities for children ages 3 to 5 " where "budding artists will be introduced to the world of art through in-gallery adventures followed by entertaining art projects" (NGC Website), the NGC also offers a "Saturday Morning Art and Photo Club" as well as the weekly "Artissimo" and the monthly "Family Fundays" where children from 3 and up (accompanied by an adult) can "experience workshops, performances, creative projects, interactive gallery visits, games and much more. Have fun, make memories and discover your hidden talents" (ibid). The NGC also offers week-long day camps for children eight and up during the March and summer breaks. These activities are not free, and of course, they are not readily available to children outside of Ottawa. For teens, the NGC offers the Teen Council which is "a diverse group of teenagers who plan activities for teens. Hours count towards the high school volunteer service requirement. The students meet after school over pizza once a month, September through June" (ibid.) and attend "Off-The-Wall" Art Workshops on the last Saturday of every month. This is one way to introduce young people to art and help them feel at home in the Gallery. ${ }^{61}$ Once again, these programs are only available to teens that have easy access to the Gallery.

Family programs at the MFA include the "Family Art Cart" which provides "fun (and educational) activities designed for children aged four and up to do with adults in the galleries", a "Sharing Art with Children" workshop for children aged six to twelve, family activity tote bags, studio art classes and workshops and school vacation week activities (MFA Website). This, too, is a way of getting

\footnotetext{
${ }^{61}$ As of 2010/2011, some of these programs at the NGC will change with the introduction of alternative initiatives by the new Director, Marc Mayer.
} 
children interested in art and at ease with art museum protocols at a very young age. It is a way of helping them develop the cultural capital that they might not get elsewhere. As noted before, however, these programs do not currently reach families in other parts of the country.

Family programs at the Museum of Modern Art introduce children and adults to "the richly varied world of modern and contemporary art"- through gallery conversations, art workshops, conversations with contemporary artists, film screenings, activity guides and interactive websites. Programs include "Tours for Fours"-a morning drop-in program specifically designed for four-yearolds and their parents or caregivers. Families are introduced to painting, sculpture, photography, works on paper, and more through interactive gallery activities and discussions, "A Closer Look for Kids"-a morning drop-in program for children aged five to ten and their parents or caregivers. Families explore artworks in the Museum's collection and special exhibitions through theme-based discussions and gallery activities. A new topic is explored each month" (ibid.) and "Tours for Tweens"-a series specifically designed for families with 11 to 14 year olds. Children and adults engage in activities, share ideas and exchange opinions about modern and contemporary artwork, film screenings, activity guides and websites (ibid.).

Family and children's programs at Tate Modern include weekend and school holiday sessions where children can try experiments with art and enjoy the USB Openings: Family Zone which offers activities to help families explore the galleries and encounter new ideas. There is the UNSketch book for children 
over six and the Seen/Unseen trail for younger children. Tate also offers a "Children's Multimedia Guide to Tate Modern" (Tate Modern Website) and has its own children's website, Tate Kids (discussed in the Chapter Six). All of these children's programs could help to dispel the idea so prevalent in the past that art is mostly for the elite (Bourdieu, 2002). At the same time, we need to ask, whose children are being exposed to these initiatives? My own observations have shown that it is almost exclusively children of the middle- and upper-middle classes that participate in these activities. ${ }^{62}$

\section{Education and Community Outreach}

All four of the case-study museums I have chosen play an important role in education and community outreach. While other programs and activities at the museums are dependent on individual initiative for participation, the education and community outreach programs not only open up their programs to schools, community groups and non-profit organizations but also take their expertise and their wares out into the community at large. In addition to the programs already discussed, the National Gallery of Canada, for example, offers teachers' workshops that "combine observation, discussion, hands-on art-making activities and resources" for use in the classroom, special programs for schools that support provincial curriculum, in-Gallery learning activities for Grades K to 12 (Ontario and Quebec) and school visits by volunteers who guide students through "looking and discussion activities" using art reproductions.

\footnotetext{
${ }^{62}$ Here I exclude children taken to museums by their schools or other community organizations.
} 
The Boston Museum of Fine Arts education program includes Educators Online, a learning tool from the MFA that allows teachers to create custom art galleries and share them with students online or in the classroom. This program also gives them the opportunity to create their own online galleries from the MFA collection, create multimedia classroom assignments, collaborate with other teachers and prepare for and enhance a visit to the museum itself (MFA Website). The MFA also has special school visits to its exhibitions and permanent collections as well as a special film series for school groups. It offers workshops and training for teachers and has annual "Student Rhetoric Competitions" for middle and high-school students.

The MFA also offers a number of other community outreach programs including partnerships with youth groups and other organizations. It provides free admission for certain (need-based) not-for-profit organizations and community visits based on eligibility. Their purpose is to provide direct services to those who find admission fees a barrier to participating in the museum's activities (www.mfa.org). The MFA also provides after school programs for children four years old and older, community programs, special-needs programs and summer camps under its Artful Adventures program. The Teen Arts Council (TAC) is "an apprenticeship program for a group of teenagers who work for the museum in a variety of leadership and learning opportunities and serve as ambassadors promoting the MFA in the Greater Boston community." The Community Arts Initiative works with after school programs to provide young people with access to the museum collections and to art-making processes and 
the Community Partners program helps young children "explore and create art" (ibid.).

Teacher's programs at The MoMA "are designed to introduce kindergarten through twelfth grade teachers to the museum's collection and special exhibitions, to offer techniques for integrating the study of art into the classroom, and to help teachers from all subject areas to find connections with the collection" (MoMA Website). These programs include professional day-long workshops as well as weekend teacher workshops and the Modern Teachers Program which prepares teaches to lead their own classes through the museum. The museum encourages school visits for children from $\mathrm{K}$ to Grade 12. The programs encourage the students to look carefully at the artworks and make their own assessments of them. MoMA also offers theme-based tours and art-studio opportunities for students of all abilities. It also offers "partnership programs involving multi-visit programs, professional development, and customized, inperson curriculum planning" (ibid.). Even more than the individual or familybased programs, these initiatives provide an opportunity for art museums to remove some of the barriers to inclusion that have plagued them in the past. If visiting art museums becomes a regular part of "what students do" while in school, it is possible that they will develop the cultural capital needed to continue visiting as adults. Studies by The National Research Centre of the Arts in 1973 and 1975 , for example, showed that "early exposure to the arts is a very significant factor in adult participation in the arts" (Newsom and Silver, 1978, p. 18). 
Like the MFA, MoMA offers a "variety of programs to non-profit community organizations that serve children, young adults, adults, families and seniors. Lectures and inquiry-based discussions can be arranged for single or multipart programs at the Museum or off-site." Programs are tailored to suit the interests and abilities of groups and "are particularly suitable for community groups new to museums" (MoMA Website). One innovative community outreach program, Meet Me at the MoMA, was started in 2006. It provides interactive tours of MoMA's collection for people with Alzheimer's and other dementia, along with their caregivers. Trained teachers engage participants in discussions by focussing on works of art from the MoMA's collection. In 2007, with an initial MetLife Foundation grant of $\$ 450,000$, Meet Me at the MoMA was expanded to become the MoMA Alzheimer's Project- conceived to broaden the reach of the original program. MoMA educators have since traveled to museums and other organizations across the country to lead workshops, seminars and in-person training sessions to encourage the development of other programs similar to Meet Me at MoMA. Training and materials are provided to all organizations at no charge. To date, more than 3,000 people have been served by these outreach efforts, and some 35 museums have participated in training on making art accessible to people with Alzheimer's and their caregivers. ${ }^{63}$

The MoMA also runs professional development workshops for community organizers and volunteers, a special program called Wider Angles adult ESOL

\footnotetext{
${ }^{63}$ In April 2009, a MoMA press release announced that the museum had received a second major grant of $\$ 400,000$ from MetLife Foundation to continue work on this project. (MoMA Press Release, New York, April 16, 2009).
} 
classes, on- and off-site programs for older adults and teleconference courses for homebound individual (ibid.). Tate Modern's education programs include group tours for schools, education and resources for teachers, special art and literacy projects with schools. Young Tate is "a youth art initiative run at all Tate's galleries by young adults for young adults, giving everyone the opportunity to reach their own conclusions about art." Young Tate also has its own website (Young Tate Website). The Tate family of galleries can be found both in London (Tate Modern, Tate Britain) and in the country (Tate Liverpool, Tate St Ives). Tate Modern does outreach to community groups and welcomes new adult audiences into the museum. Its Art into Life program also provides free workshops for community members.

These are all examples of the "museum as educator" role. They are inclusive and non-discriminatory and are one indication of how the roles of art museums have changed over the years. Fifty years ago it was inconceivable that such a revered institution as the Tate, for example, would venture out into the British countryside. Not only that, a visit to an art museum was a very serious affair with none of the accessories offered to today's visitor. There were no didactic panels, no audio-tapes and no children's programs. School visits were rare and extra-curricular activities were almost unheard off. Furthermore there were very few restaurants, bars, cafés or shops. ${ }^{64}$

\footnotetext{
${ }^{64}$ Although some museums might have offered cafeteria style food in the basement or back of the building, and venders may have offered a limited supply of postcards and/or books very little else was available (participant experience from visiting art museums in England and Holland in the 1950's).
} 


\section{Summer Blockbusters and Other Popular Events}

If many activities conducted at art museums are targeted towards the wealthy or highly educated, one activity that does reach out to wider publics and nets large amounts of money is the summer blockbuster. By blockbuster I mean those popular exhibitions of big name artists—most especially the Impressionists or Old Masters shown during summer-that draw thousands and sometimes hundreds of thousands, of people into the exhibition complex. ${ }^{65}$ For example, over the past ten years, the National Gallery of Canada has exhibited, among others, Alex Colville (2000), Gustav Klimt (2001), Tom Thompson (2002), Leonardo da Vinci, Michelangelo and the Renaissance in Florence (2005), Emily Carr (2006), Ron Mueck $(2007,2008)$ and Renoir $(2007,2008)$-all popular choices with the general public. ${ }^{66}$ During the same period, the MFA hosted exhibitions that included Gauguin,/Degas/Picasso/Matisse (2006), The Impressionists $(2006,2009)$ and Van Gogh $(2008,2010)$. The MoMA showed Matisse/Picasso (2003), Cezanne/Pissarro (2005), Alexander Calder (2007) and Manet (2009), while Tate Modern showed Warhol (2002), Matisse/Picasso (2003), Frida Kahlo (2005), Henri Rousseau (2006), Kandinsky (2006), Dali (2007) and Rothko (2008).

\footnotetext{
${ }^{65}$ The Matisse/Picasso Exhibition at Tate Modern in 2002 drew over half a million visitors, for example, (Tate Modern Website). The same exhibition, shown at the Grand Palais in Paris in 2003 drew over 9000 people a day (Culture Kiosk Website)

${ }^{66}$ When asked if it would be possible for the National Gallery of Canada to host Oskar Kokoschka, Egon Schiele or even the Bauhaus or the Abstract Expressionists, the then director, M. Théberge, simply smiled, said "that would be nice," and moved on (participant encounter, 2003). The new Director, Marc Mayer (2009), seems to have a different approach. He has already brought Nozkowsky and "Pop Life: Art in a Material World" to Ottawa (straight from Tate Modern and Hamburger Kunsthalle). It remains to be seen how much he will be able to change the NGC.
} 
If my earlier research indicated that most of the programs and initiatives at the four case-study museums were targeted towards the social or intellectual elite, the education and community outreach programs ${ }^{67}$ as well as the summer blockbuster tradition ${ }^{68}$ in all four institutions, provide a rather different picture.

They show that despite the focus on elite patrons and donors, many art museum professionals are beginning to respond to the needs of wider publics by providing opportunities for children and less educated members of society to enjoy the art museum experience in new and different ways.

\section{Conclusion}

This chapter has taken a close look at the four case-study museums I selected, examining the ways in which they engage their diverse publics. It has assessed the benefits offered to members, donor, benefactors and other patrons, asking why people join and suggesting that in addition to loving art and wanting to support the museums, some people might join to enhance their self-esteem and their position in the society, constructing elite subjectivities for themselves by participating in these elite activities (Glynn, et al., 1995, Duncan, 1995, Preziosi, 2003). This chapter has also analyzed the four museum journals/magazines and their brochures, catalogues, newsletters and e-communications and their

\footnotetext{
${ }^{67}$ I deliberately do not include family/children's programs here because they depend on individual participation that rely for the most part, on the families themselves-thus excluding many children from the opportunity to participate - whereas school and community programs can reach children and even adults who have not necessarily made a conscious effort to seek out the museum experience. This is not in any way meant to down-grade family and children's programs.

${ }_{68}$ The blockbuster tradition has been criticised in recent years for giving the public what it wants in order to raise the numbers of visitors and amounts of money collected rather than introducing it to less well known pieces of art-most noticeably by the former British art historian, Francis Haskell (Haskell, 2000).
} 
lectures, films and music. It has found that, for the most part, these publications speak to individuals with a great deal of cultural capital (Bourdieu 2002, Gans, 1999). These are just some of the hidden barriers my thesis has explored. At the same time, my research has shown that summer blockbuster exhibitions as well as family, school and outreach programs are going a long way towards meeting the needs of more diverse publics, especially children.

My next chapter examines the roles of built structures (inside and out) as well as those of the cafés, bars, restaurants and shops at the museums I have selected to determine if these, too, contribute to the exclusion of some publics from the art museum experience. 


\section{Chapter Four - Architecture and Ambiance, Cafés, Bars, Restaurants and Shops}

We shape our buildings and afterwards our buildings shape us...

Winston Churchill, 1943

\section{Introduction}

If education and outreach programs help to attract new publics to the art museum complex, their architecture and ambiance-m depending on the messages they send—can be either warm and welcoming or cold and rejecting. In addition, museum shops, cafés, bars and restaurants all contribute to the general atmosphere of the institution and can be read as texts just as programs, privileges and publications can. Art museum buildings, for example, can be inviting or excluding depending on their exteriors and/or their interiors. Their lightness (glass and steel) or their heaviness (stone and wood), their accessibility (straight off the street) or their isolation (set back from the street, raised with steep steps, and as Duncan says, set apart in grounds of their own, 1995): all send important messages of exclusion or inclusion to potential visitors. A traditional Gothic or Neo-Gothic building, for example, with its imposing arches, fluted columns and extravagant entrances might be intimidating to an apprehensive visitor, especially if it resembles a palace or a castle, which were both, traditionally, the venue of the monarchy or the aristocracy. In addition, a heavy wooden door or a thickly barred window might suggest another kind of barrier. 
This chapter explores the exterior and interior of the four case-study art museums I have selected (The National Gallery of Canada, The Boston Museum of Fine Arts, The Museum of Modern Art in New York and Tate Modern in London) to determine to what extent we might say that they are either welcoming or deterring, inclusive or exclusive-that is, it asks "What messages do these buildings communicate and how might their various publics interpret them?". The chapter takes a semiotic approach, assuming that each building (inside and out) is itself a signifier and that each visitor receives a unique signified or sign that depends on her or his own subjectivity and social/cultural background. ${ }^{69}$

I begin with a brief review of the exteriors (constructions, materials, locations, accessibility, etc.) of each museum and then move inside to discuss how layout, design and museum protocols affect the behaviours of potential visitors. That is, I look for hidden barriers in the buildings themselves that could potentially deter some individuals from approaching the museum. I follow this with an analysis of the shops, cafés, bars and restaurants to determine what roles they, too, might play in attracting or deterring visitors ${ }^{70}$

\footnotetext{
${ }^{69}$ By this I mean that each visitor will have a unique response to the building depending on his or her socio-cultural background. For example, while one visitor might feel intimidated by the grandeur of the MFA building, another might feel quite at home there.

${ }^{70}$ Jameson's analysis of the Bonaventure Hotel and Benjamin's Arcade Project, as well as Baudrillard's discussion of Beaubourg, were useful reading here, as they helped to legitimize my belief that buildings, the space around them, and the space inside them, in and of themselves, can send powerful messages to their various publics.
} 


\section{Architecture and Ambiance}

\section{The National Gallery of Canada}

The National Gallery of Canada building is an elegant structure on the edge of Ottawa's Byward Market, "across" the river from the Parliament Buildings and the National Library. Designed and built in 1984 by Montreal architect, Moshe Safdie, it has been called, variously, a shopping mall (Ferguson, 1996, p. 182), a Chrystal Palace (Monica, Virtual Tourist Website, 2008) and "a living part of Canada" (Prime Minister Brian Mulroney, Ottawa Citizen, May 11, 2000). It could also be viewed as a church or a cathedral. Its glass, concrete and granite construction and its octagonal towers (mirroring the Parliamentary Library and other similar buildings across the river) might be seen as either postmodern ${ }^{71}$ (mock) gothic revival, mirroring the parliamentary library and other similar buildings across the river or as a bold statement of late twentieth century architecture, or maybe both.

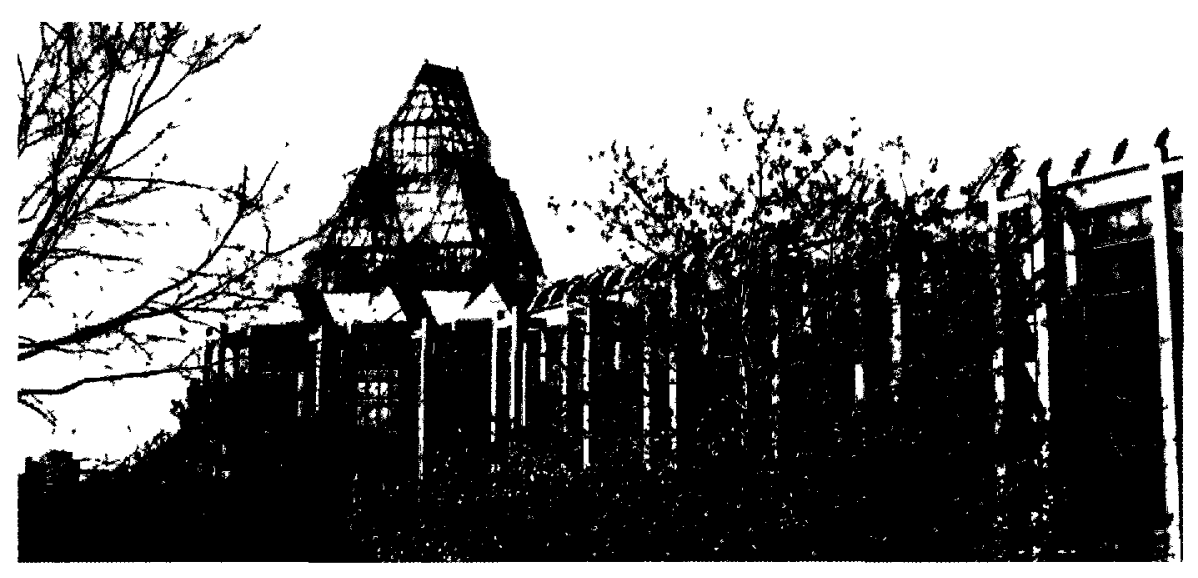

The National Gallery of Canada, Ottawa (Photo: Wendy Quinlan-Gagnon, 2010)

\footnotetext{
${ }^{71}$ Saftie denies any link to the post-modern, but if we define postmodernism (in part) as an ironic duplication of old forms then perhaps this is something we might question (Safdie's Gallery, Turner, 1989).
} 
The amphitheatre-like circle of stone "benches" on the south side of the building invites visitors to sit, rest, picnic or just talk in a very informal way. Its street-level (but not off-the-street) entrance welcomes visitors from the "plaza" outside.

Once inside the building, visitors find themselves in an open space beneath the first of the octagonal glass towers. The information booth and ticket counter is just inside the door, while the bookshop beckons from across the lobby. To the left, the long, straight, colonnade ramp guides visitors north towards the Great Hall-the central point of the museum. Described by Ferguson as both fascist and forbidding (1996. p. 182) the long colonnade ramp may seem "cold" and unwelcoming to some visitors. On the other hand, it could be seen, with its breathtaking views onto, and across, the river, as an enticing "avenue," guiding visitors towards the exhibition rooms and, of course, to the Great Hall itself.
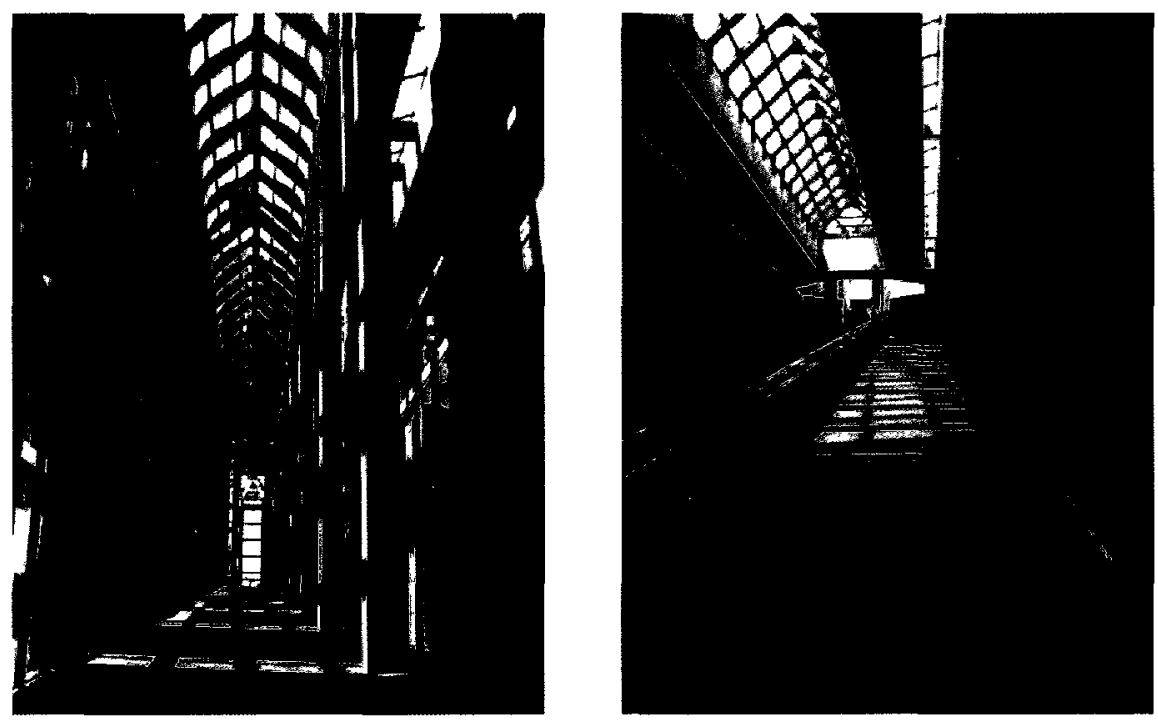

Colonnade Ramp and Stairs, NGC, Ottawa (Photos: Wendy Quinlan-Gagnon, 2010) 
In some ways the colonnade ramp resembles the nave or aisle of a Christian church, the long narrow passage leading to the apse (the Great Hall itself). If, as Marstine (2006) says, an art museum is a shrine or temple, perhaps the long journey up the ramp to the viewing rooms symbolizes a quest-for art and knowledge.

Except for a small café (Café L'Entrée) in one corner, this large space is empty but can be transformed at a moment's notice for gala receptions, dinners, Christmas celebrations or the children's Artissimo. ${ }^{72}$ Despite this, however, the Great Hall is not all things to all people as Ferguson suggests (see below), but an exclusive venue for a number of exclusive Canadian (or international) publics that range from wealthy patrons to middle class donors or intellectuals to students of art or the children of the above ${ }^{73}$-all privileged members of society. Street people, the homeless, low-income immigrants and refugees, the very poor do not appear to populate this famous hall. ${ }^{74}$

Ferguson argues that the soft ("consumer accessible") exterior and entrance and the hard ("authoritative if not authoritarian") interior of the NGC reflect the Gallery's "unconscious desire to be all things to all people" (ibid), and he may be right. Nonetheless, the building seems to over-power the art inside, in some curious ways. That is, it is a building that shouts "look at me!"-a work of art in itself that may be more admired for its outside than for what it holds within.

\footnotetext{
${ }^{72}$ During Prime Minister Jean Chretien's time, the Great Hall was a favourite place for government receptions.

${ }^{73}$ School groups would form an exception to this-although we might ask which schools?

74 I say "famous" because the National Gallery's Great Hall is well known around the world and has been written about at length. Douglas Ord, for example, has likened it to both the Temple Mount and al-Haram ash-Sharif in the Old City of Jerusalem and Lawren Harris's painting Icebergs, Davis Strait (Ord, 2003 p. Xii).
} 
That said, the exhibition rooms themselves are large and well lit with intermittent natural light brought into the Gallery by light shafts from above. Each room has been carefully planned to suit the contents; the Baroque Room is red; the Barnett Newman Room is white, for example. The vaults and soft light are "calming" (Safdie in Turner, 1989, p. 13). All of this adds to its attractiveness and level of ease with which visitors can tour the exhibits as they unknowingly experience the "ideologies" of the art museum experience (Duncan, 1995, p. 8). The unwritten protocols for art museum viewing-Bennett's reformatory of manners, perhaps (Bennett, 2002, pp. 4-5)—dictate that visitors remain quiet, walk slowly, refrain from blocking another person's line of vision, avoid touching the exhibits and generally show polite disinterest in other visitors, while seriouslooking guards roam the salons, ready to pounce at the slightest (real or imagined) infraction. For example, once when my seven and nine-year-old grandchildren were looking intently at the brush strokes on a Riopelle, they were brusquely warned to move back even though they were not close to touching the painting. Such unnecessary interventions hardly make the Gallery a welcoming place for young visitors. At the same time, it seems like an extraordinary leap of faith for museum directors and curators to allow so many priceless works of art ${ }^{75}$ to be put on display in any art gallery or museum without more robust protection. ${ }^{76}$ Marstine's notion of the museum as "shrine" or sacred space

\footnotetext{
${ }_{75}^{75}$ Priceless only, of course, because the market has deemed them to be

${ }^{76}$ One can only think of the difference between the paintings and sculptures on (virtually unprotected) view in an art museum and the Olympic Flame in Vancouver 2010 so thoroughly guarded from its publics. Perhaps this is because an art museum audience is considered well educated and elite while the audience for the Olympic flame consisted of a more general public.
} 
(Marstine, 2006, p. 9), or Bennett's (1995) self-governing citizen may be in play here.

So does the National Gallery building attract or deter visitors? Despite its location near the ByWard Market ${ }^{77}$, I would say that it is more a destination than a drop in venue (like the MoMA, for example, or Tate Modern). And while its glass and steel exterior seems very appealing, it is possible that the inside maybe somewhat cold and daunting to some. Also, although it is at street level, it is not, as already noted, off-the-street. It is set back away from the everyday with its own structural markers (Duncan, 1995) which may, in itself, present a barrier for some potential publics.

\section{Tate Modern}

If the National Gallery of Canada building is one which visitors love to admire from the outside, the same can hardly be said of the Tate Modern building $^{78}-\mathrm{a}$ (former) decommissioned power station at Bankside in London's Southwark ward, across the river from St Paul's Cathedral. Said to be one of the very few art museums designed with art (as opposed to architecture) in mind ${ }^{79}$ (Martin, 2000 , p. 13), it was originally identified by Martin as a dreary "red brick" 80

\footnotetext{
${ }^{77}$ The Byward market is a popular tourist location in Ottawa,

${ }^{78}$ The addition of Herzog and de Meuron's new extension (Tate Modern 2) on the south side of the building started in 2008, and due to open at least in part by 2012 may change this observation.

${ }^{79}$ Others include the Dupont Foundation in Tilburg and the Hallen fur Neue Kunst at Schaffhausen near Zurich (Martin, ibid.). Safdie has claimed the same for the museum in Ottawa (Turner, 1989, p. 16).

${ }^{80}$ The term "red brick" used by Martin is an interesting one since the brick of Tate Modern is mostly yellow and not red. In England, the term "red-brick" is used to describe the (more plebeian) provincial universities to distinguish them from the elite universities of Oxford and Cambridge. I'm not sure if we can make anything of this-but the Blair government was
} 
construction in a neglected area of London that had gone unnoticed for years (Martin, ibid.).

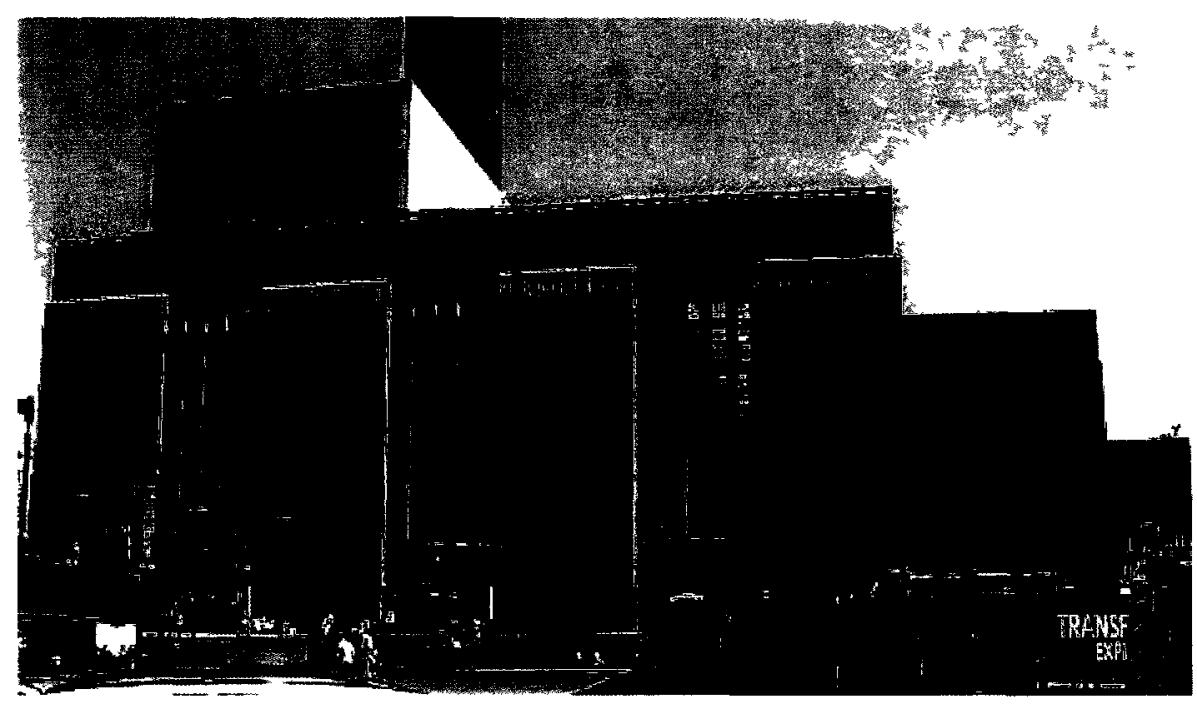

Tate Modern at Bankside - West Entrance (Photo: Imtyaz Mohamed 2010)

After an open competition to which close to 150 architects responded, six were short-listed to go before the final jury. The Swiss firm of Herzog \& de Meuron won easily as it was the only firm that completely accepted the form, materials and industrial characteristics of the existing building, and proposed to work with them to create an exciting new space for modern art. Others treated it as a shell within which to construct a new building or suggested incorporating a more modern structure into the old building ${ }^{81}$ (Martin, p. 18).

Selecting the old power station for the new Tate Modern was a controversial and brave move by the Tate Trustees as many of Britain's

pressuring for a more democratic and inclusive approach to the arts at the time Tate Modern was conceived

${ }^{81}$ One Britısh firm even suggested removing the tower completely (FT Weekend, 1-2 May, 2010, p.10-11) 
architects were ardently opposed to it, seeing it as a missed opportunity to construct a grand new building for central London (Martin, ibid. p. 17). But that was the whole point! According to Martin, "the most sympathetic and stimulating places in which to see modern and contemporary art are in older buildings converted from earlier industrial or other-purpose constructions" (ibid.). This was confirmed by the majority of artists responding to a questionnaire conducted by the Tate before the final decision was made (ibid.). Thus the choice of the Bankside site was neither about a beautiful building nor about public comfort with the building, but about art, although I would argue that Herzog and de Meuron have given the present-day art viewers both an arresting interior and a building to enjoy - in addition to a spectacular place to view Modern and Contemporary Art. Herzog and de Meuron's Tate keeps the outer look of the old power station virtually intact, with the single addition of a new two-storey-high frostedglass beam running across the entire length of the building, signalling a change of function and providing lots of natural light to the top floor galleries. Smaller buildings around the perimeter were removed and the area was replaced with grass and other plants making a welcoming place for visitors to relax. The original area of the large turbine hall was maintained, but with the "ground floor" pushed down to basement level to open the space even more. A large concrete ramp, the width of the turbine hall, was added to form the West entrance-way, making a road-like extension of the (newly created) piazza outside (Martin p. 21). This large entrance, leads straight into the turbine hall. 


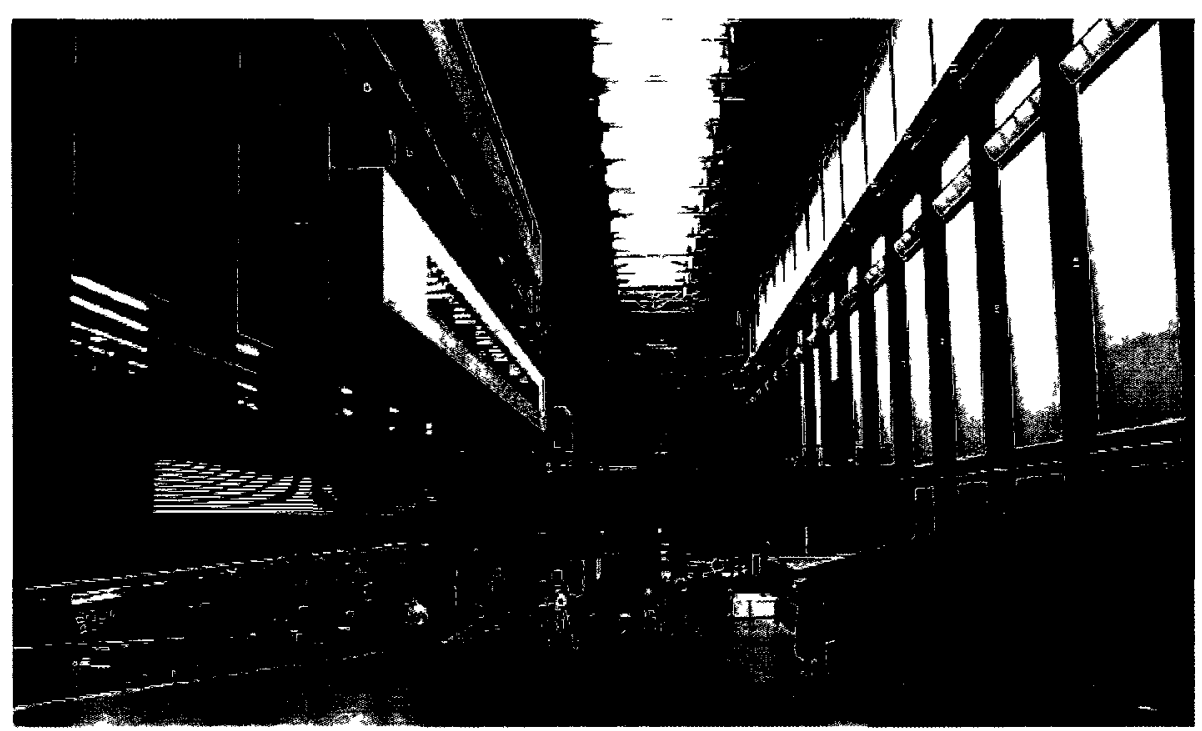

Tate Modern: Ramp Leading to the Turbine Hall (Photo: Imtyaz Mohamed, 2010)

Because of its size and shape, there is a natural flow of visitors arriving from the adjacent Millennium Bridge (a walking bridge that crosses the river in front of St Paul's Cathedral) and from the embankment in front of the piazza, as there is no street to cross or traffic to contend with. This is so not the art-museum-in-apalace construction that was (and sometimes still is) the usual setting for major works of art (Le Palais du Louvre in Paris, The Belvedere Palace in Vienna and The Heritage in St Petersburg, The Boston Museum of Fine Arts, The Metropolitan Museum of Art in New York, for example)—so not a place outside of, and separate from, day-to-day time and space as Duncan still believes many contemporary art museums to be (Duncan, 1995, p. 11). With its industrial flavour of concrete, untreated wooden floors and steel beams, Tate Modern seems to fill the requirements of the "new kind of art museum" called for by John Cotton Dana in 1917, when he said that an art museum should be located where 
it can be reached by the maximum number of persons with a minimum of expenditure in time and money and built of material and style appropriate for a modern city (Cotton Dana, in Anderson, 2004, pp. 13-29). Once a source of light for people's homes this decommissioned power station has been transformed into a source of enlightenment for people's minds.

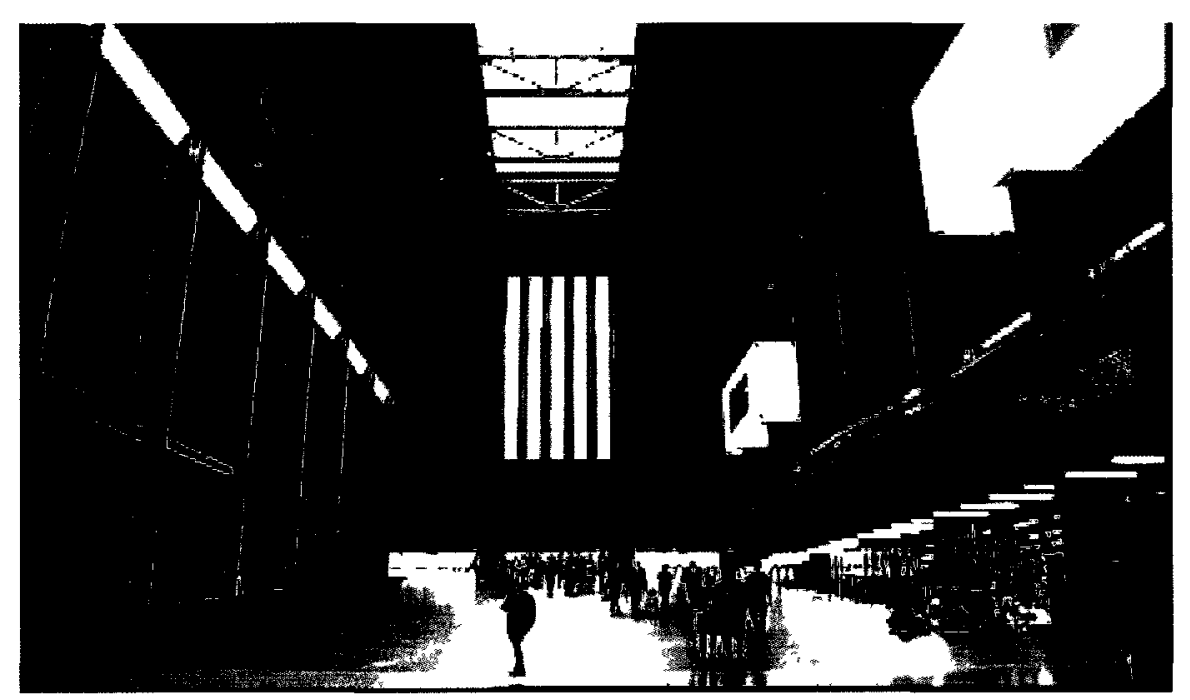

Tate Modern: The Turbine Hall (Tate Website)

The transition from outside to inside Tate Modern is easy, and once inside the turbine hall, visitors can "stroll around quite naturally" (Herzog, 2000, DVD). It is "open and public, like a city landscape" (ibid.) with an informal, relaxed atmosphere that welcomes visitors of all ages_allowing for many small children in strollers, or young teens just sitting and talking, or older people relaxing with books or newspapers - a rare sight in a public art museum. The pictures below, taken from Beat Kuert's film, Tate Modern, (Kuert, DVD, 2000), show people at ease or relaxing in the galleries, signifying the degree of visitor comfort with the museum and the grounds outside. 


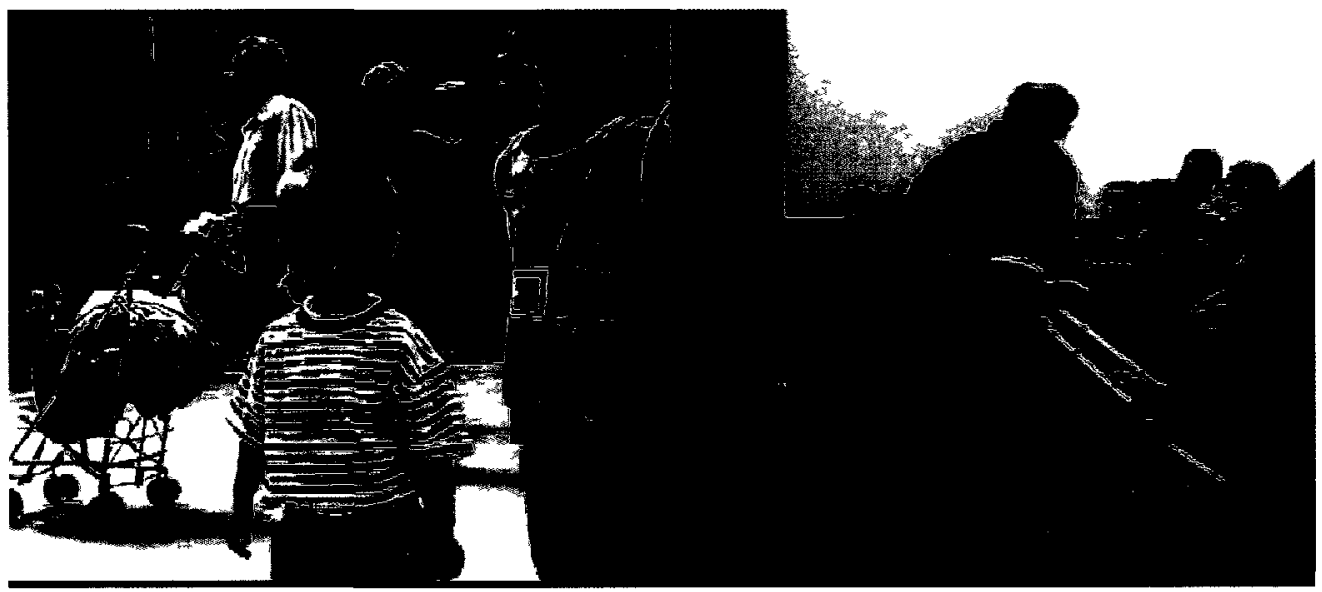

Small chıldren at Tate Modern on Opening Day
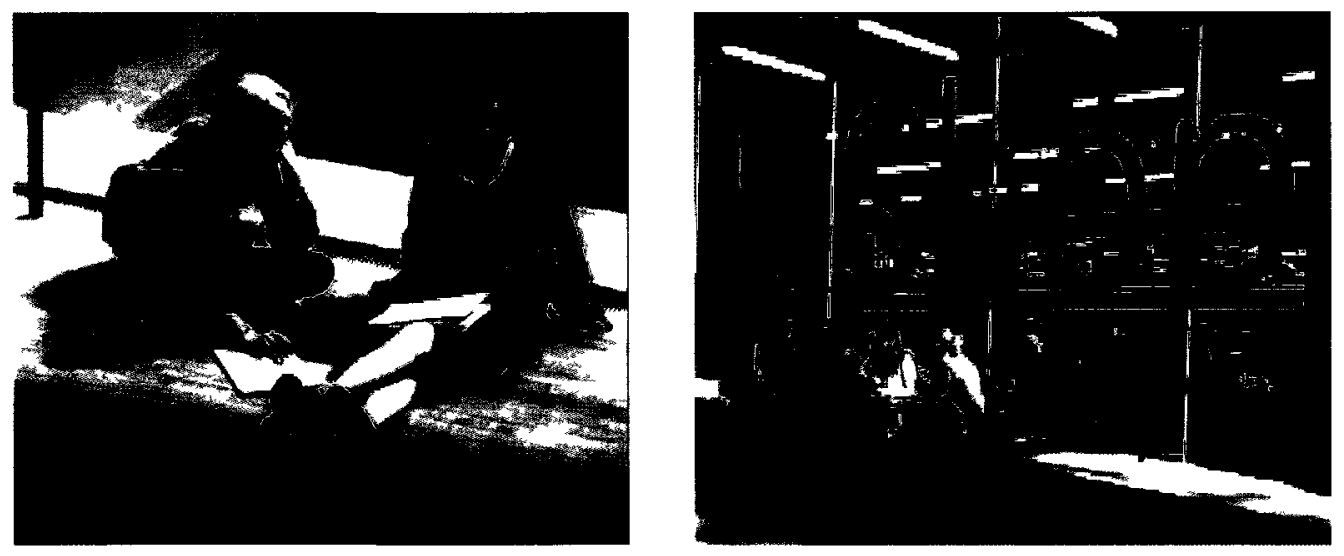

Young teens enjoying Tate Modern
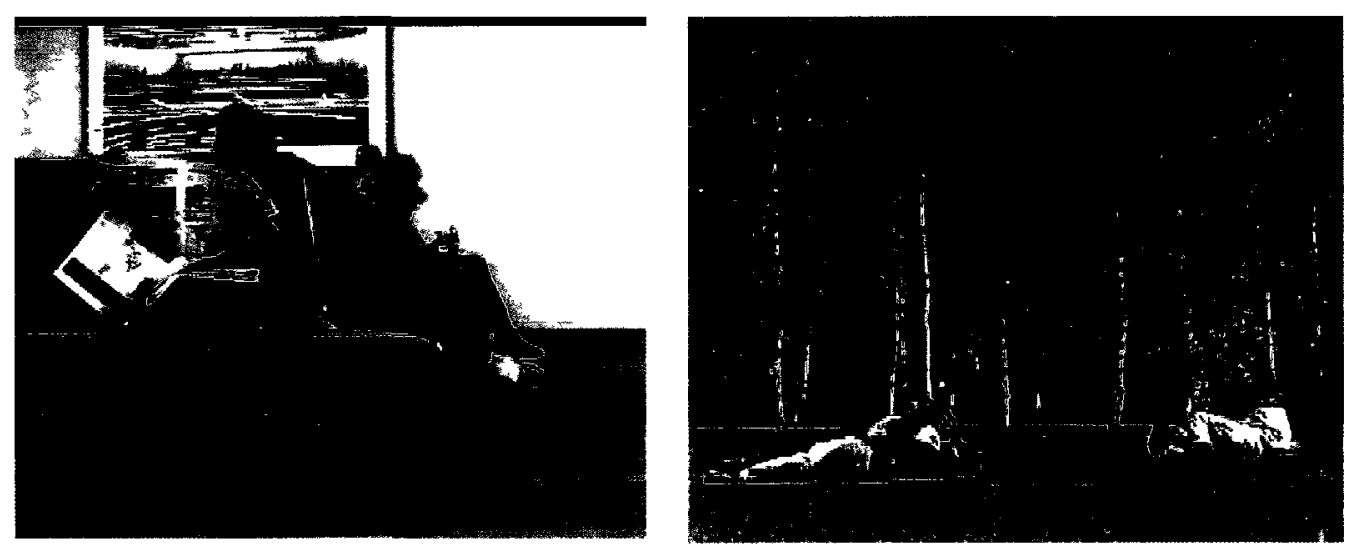

VIsitors relaxing inside and outside of Tate Modern (Kuert, DVD, 2000)

The relaxed atmosphere of the entrance and the turbine hall carry over into the exhibition galleries, which are located on newly constructed floors in what 
had formerly been the old boiler house. Professor Mignon Nixon of the Courtauld Institute of Art in London, has suggested that one reading of Tate Modern's strategy might be that it cuts "across old hierarchies to make the museum a more popular public place" (Nixon, Tate Round Table, 2001) with its thematic juxtapositions and ahistorical non-linear "hangs". Tate Modern began by showcasing its permanent collection in four broad themes: Landscape, Still Life, The Nude and History. This departure from the traditional chronological hang invites a different way of looking at art. A second, also ahistorical, re-hang in 2006 saw current works juxtaposed beside works from the past-making the art both "challenging and empowering for visitors" and letting them explore it on their own terms rather than being directed on how to look (Gale, The Telegraph, 11 May 2010). While I recognise that visitors to art museums are always free to go where they choose, there is a tendency with more traditional hangs for visitors to follow a pre-determined route-especially during temporary exhibitions.
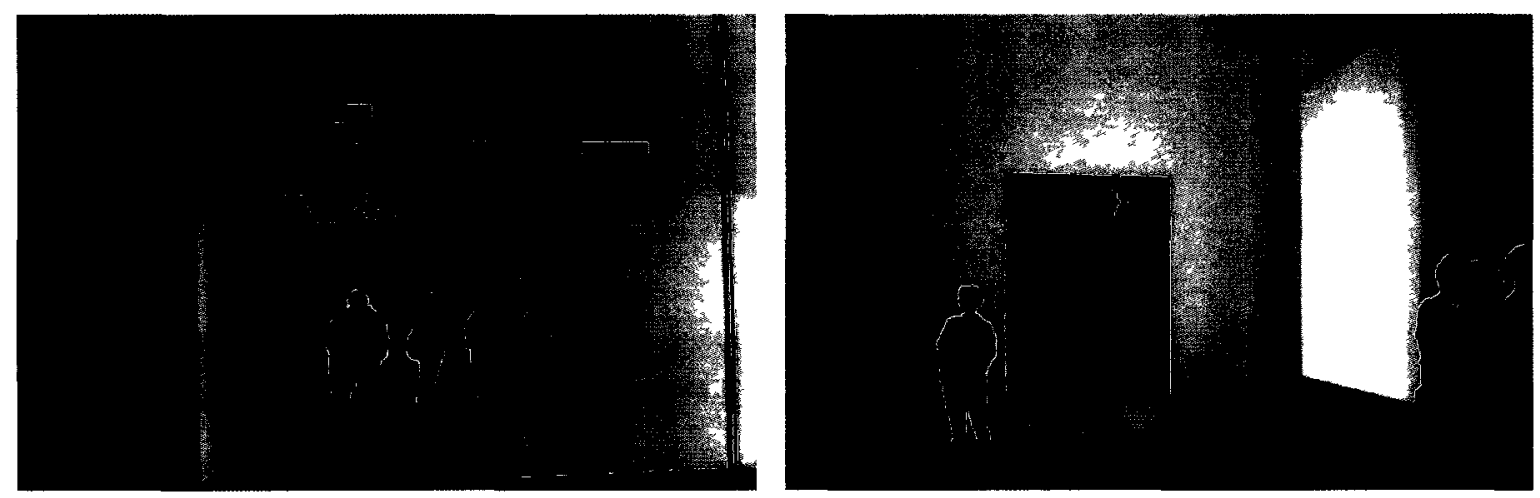

Viewing Rooms at Tate Modern (Photos: Imtyaz Mohamed, 2010)

The exhibition rooms, themselves, are spacious and well lit, with both natural light and artificial light combining to produce a comfortable ambiance for viewing. 
Where there is no natural light, overhead light fittings hidden deep in the ceilings provide a soft light with which to view the paintings.

Like the National Gallery of Canada, the large windows at Tate Modern provide visitors with stunning views of the city outside of the museum. This gives it a secondary role as a lookout point ${ }^{82}$ as well as a museum. Furthermore, the old power station's factory-like exterior, welcoming entrance, industrial-design interior, casual ambiance and accessible viewing rooms are far less intimidating than a more formal "purpose-built" ${ }^{83}$ building might have been. In an interview with the British newspaper, The Telegraph, (May 2010) artist Michael Craig Martin argues that Tate Modern's "physical openness has broken down many barriers," adding that it "feels welcoming"..."free" and "unpretentious" (The Telegraph, 11 May 2010). In the same article, Sandy Nairne, director of the National Portrait Gallery, claims that the facilities and the layout of the museum encourage lots of "different kinds of groups" and "different combinations of families" (ibid.) to attend. Finally, in an interview with the Financial Times Weekend art historian Simon Schama called Tate Modern a "popular, democratic institution" (FT Weekend, Life and Arts, 1, 2, May 2010, pp.10-11). Tate director Nicolas Serota has also suggested that the museum's popularity comes from the building itself and from "the way in which art is shown" adding that it has "become an institution that people regard as very approachable" (ibid.). This combined

\footnotetext{
${ }^{82}$ Briony Fer, a second member of Tate Round Table, argues that Tate Modern opens up a series of vistas and viewpoints on London that had never been seen before (Tate Round Table, ibid,p.16).

${ }^{83}$ By "purpose-built" I mean buildings built especially to serve as art museums. Martin reports that recently (circa 2000) built art museums designed to house contemporary and modern art at Bonn, Frankfurt, Munchengladbach and Maastricht were more about architecture than about artists and art (ibid. p. 17)
} 
with its proximity to the Embankment, to the Millennium Bridge and to the new Southwark tube station positions it well to attract large numbers of visitors (close to 50 million in its first 10 years of operation).

\section{The Museum of Modern Art}

The Museum of Modern Art (MoMA) in New York houses a very exciting collection of modern art. Its building, straddling a block between West $53^{\text {rd }}$ Street and West $54^{\text {th }}$ Street in downtown Manhattan, ${ }^{84}$ is clean, modern and chic.

Flanked by $5^{\text {th }}$ Avenue to the south and the Avenue of the Americas ( $6^{\text {th }}$ Avenue) to the north, it is well-positioned to capture both local and tourist traffic.

Furthermore, its sober glass and steel store-front exterior gives no indication of the exciting space within. Its "right off the sidewalk" entrance, even more than Tate Modern, allows visitors to flow in and out almost seamlessly. Inside it is extremely noisy—a possible sign that the old "reverence" for art (Marstine. op. cit.) has all-but disappeared. It is as if the outside had been brought inside, the museum an extension of the busy city itself. Like Tate Modern, the MoMA defies Duncan's claim that many contemporary art museums are set apart from the dayto-day by structural markers that emulate the old idea of an art museum as a sacred space (Duncan, 1995, p.11). ${ }^{85}$ This does not mean that protocols are discarded or that museum guards are not strategically located to ensure that no harm comes to the art. It does mean that, as in Tate Modern, there is "freeness" to the viewing practices that, I would claim, are a direct result of the ambiance of

\footnotetext{
${ }^{84}$ The main entrance to the MoMA is at 11 West $53^{\text {rd }}$ Street

${ }^{85}$ Of course, Duncan does not say that all contemporary art museums follow this model.
} 
the building. By this I mean that in addition to its proximity to shops and other urban buildings and the almost haphazard way people can wander in and out from the street, the simplicity of the entrance, the spaciousness of the atrium, the juxtaposition of the viewing rooms and the views to the city outside all contribute to making it a welcoming place in a very real and democratic way. And this, combined with the casual way in which visitors can appreciate and explore the galleries, browse in the shop or relax in the reading room introduces a lightheartedness to the MoMA that one does not often find in art museums. In addition, the security guards are discreet and polite when they need to intervene, creating a non-threatening environment that visitors of all shapes, sizes, ages, social strata and ethnic groups can appreciate and enjoy.

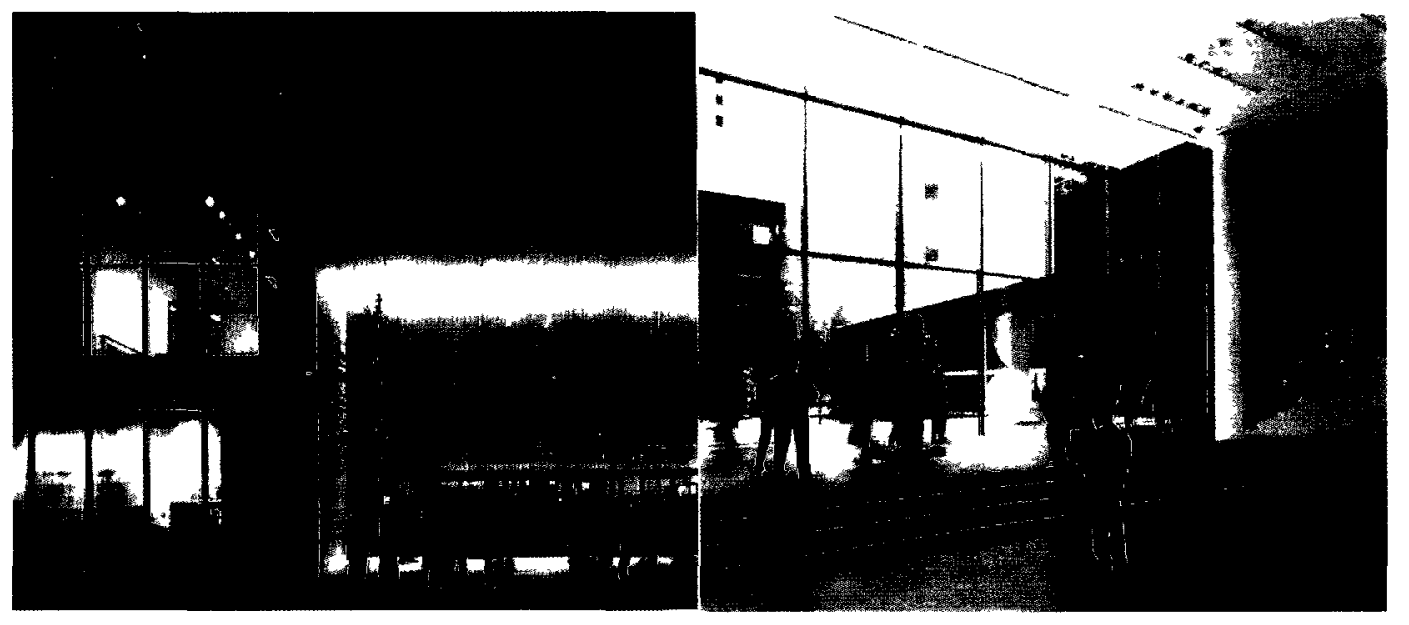

MoMA Entrance - Outside and Inside (Photo: Lowry, 2005)

The sense of inside/outside one feels when entering the MoMA from the street is sustained as one continues through the entrance hall towards the Abby Aldrich Rockefeller sculpture garden. This open space, situated right in the centre of the museum complex forms a walled courtyard or piazza which is 
sunken several feet below street level and surrounded by terraces that border the museum building on all sides (Lowry, 2007, p. 19)

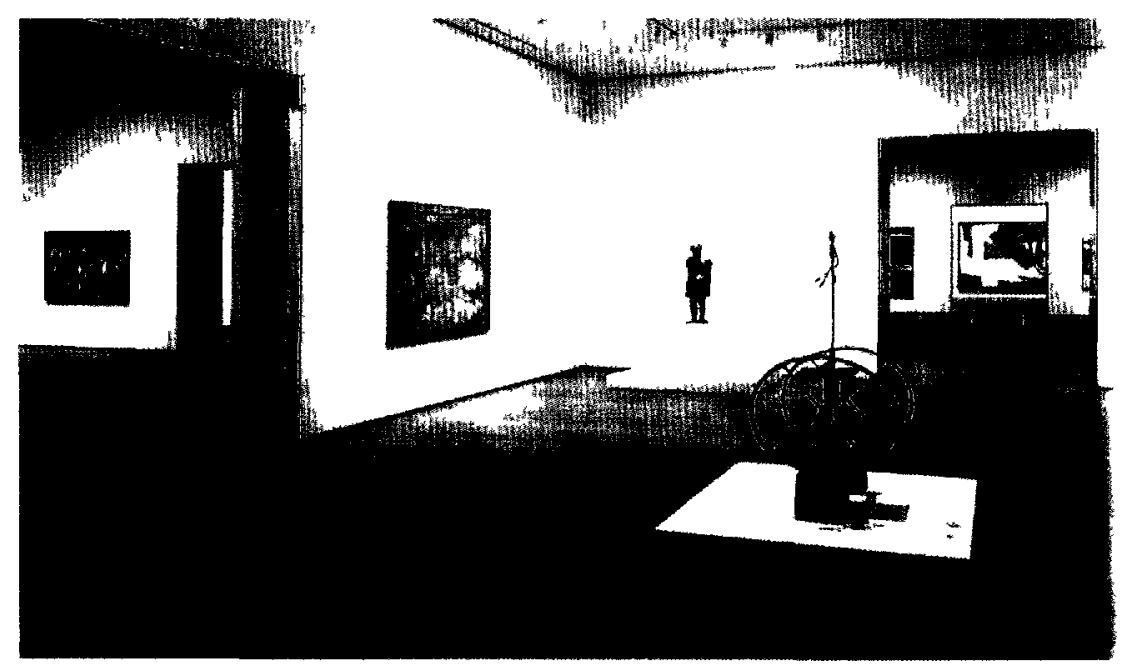

MoMA: The Viewing Galleries

(Photo: Wendy Quinlan-Gagnon, 2010,)

The viewing rooms are light, airy and pleasing. Taniguchi has created a series of spaces ... "that encourage visitors, with their multiple entrances and exits, to feel at ease with the collection and to chart their own way through the Museum, disrupting or altering the very narrative the Museum presents" (Lowry, 2009, pp. 27-28). Leather benches, strategically placed throughout the viewing rooms encourage visitors to linger and enjoy the art.

Despite all of this, the architecture of the MoMA building is not without its detractors. Some critics have said it is "too large and too corporate" while others have criticised the museum policy itself, saying it does not do enough for contemporary art. Still others bemoan its commitment to the contemporary and fault it for trying to be all things to all people (Lowry, ibid., pp. 37-38). It has also been criticized as being the "grand patrician" ... "no expense spared", kind of 
building that focuses (too much) on the "aesthetic grandeur" of its collection (cited by Simon Schama, FT Weekend, 1, 2 May, 2010, p. 10 - no source given). Regardless of this, or maybe because of it, the MoMA has emerged as an institution that attracts people from many walks of life through its openness and commitment to providing a welcoming space for its visitors. That said, at $\$ 20.00$, the entrance fee may constitute a barrier for some potential MoMA visitors.

\section{The Boston Museum of Fine Art}

The Boston Museum of Fine Art sits elegantly and aloofly in its own grounds, located between Huntington Avenue and the Fenway in downtown Boston. It fits exactly Duncan's description of an art museum as set apart, away from the day-to-day. Its Greco-Roman exterior with its four-column pillared portico on the Huntington Avenue side and its 22 column facade on the Fenway side ${ }^{86}$ is everything the other case-study museums are not. It is formal and elegant with none of the urgency of either the MoMA or Tate Modern, and none of the shopping mall appeal of the NGC. Its cut-granite facade, stretching for more than five-hundred feet along Huntington Avenue (Melton, 2009, p. 24) is reminiscent of the Belvedere Palace in Vienna or the Hermitage in St Petersburg, both formidable buildings with daunting pasts. The MFA building speaks power and authority. But this is part of its purpose. It is what one would have expected from a serious art museum in the past. Its original architect, Guy Lowell, had a classical background and had studied at the Ecole des Beaux Arts, in Paris (ibid.

\footnotetext{
${ }^{86}$ The Fenway entrance was renamed the "State Street Corporation Fenway Entrance" in 2008 in honour of State Street Corporation's $\$ 10,000,000$ gift towards the museum's ongoing expansion (Lowry, ibid.)
} 
p. 20) and he brought that experience back to Boston. Here more than in any of the other three museums one can see Bennett's repository of manners, Duncan's (1995) site of ritual, Marstine's (2006) shrine or Cameron and Clarke's temple (op. cit. 2004, 1006)—but not John Cotton-Dana's (in Anderson, 2004) easily accessible museum "available to the maximum number of persons with a minimum of expenditure of time and money.")

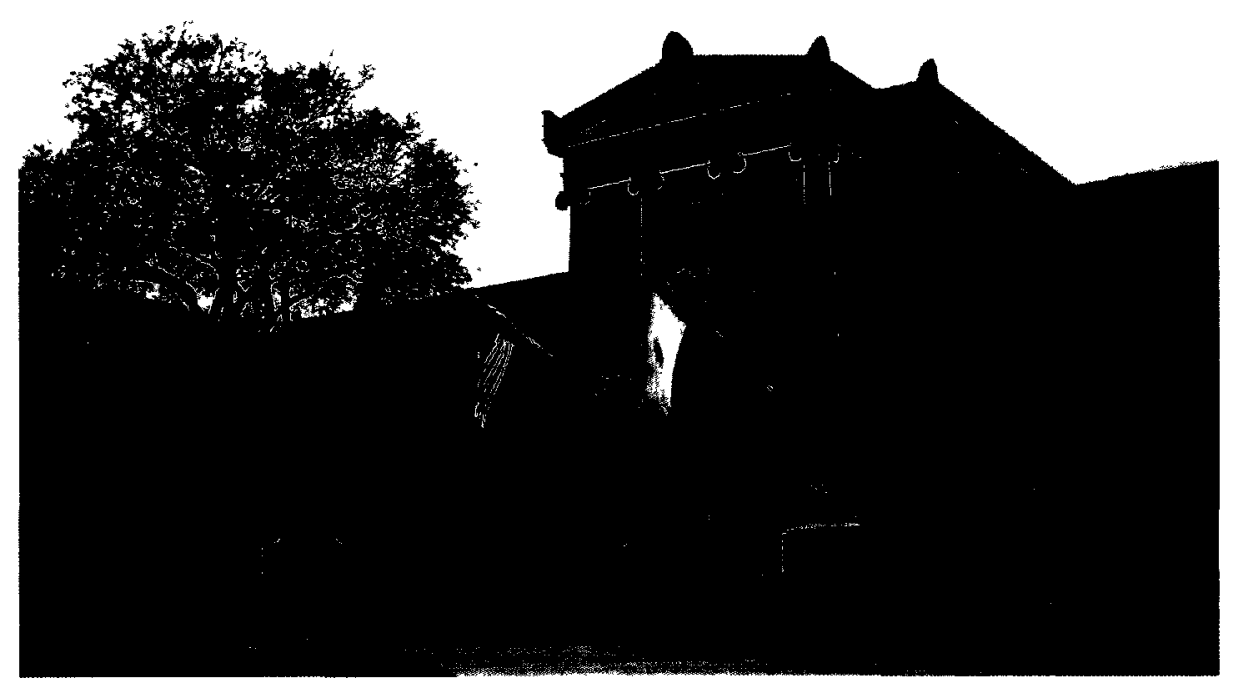

The Boston Museum of Fine Art, Huntington Ave (Photo: Wendy Quinlan-Gagnon 2010)

The MFA is not a place one stumbles on accidently. It is a deliberately sought out destination. To spend time in the MFA, visitors must go out of their way to get there, climb several stone steps and enter through a large, heavy, brass and wooden door. This is a museum that speaks "reverence" for art, sees art as something separate from the everyday. Inside, its grand staircase, vaulted halls and spacious second floor rotunda provide an "architectural focus and gateway to the exhibition galleries" (ibid. p. 25). The main viewing galleries are 
austere with little natural light—many windows are covered with a semi-opaque material with artificial light focused on the artifacts.
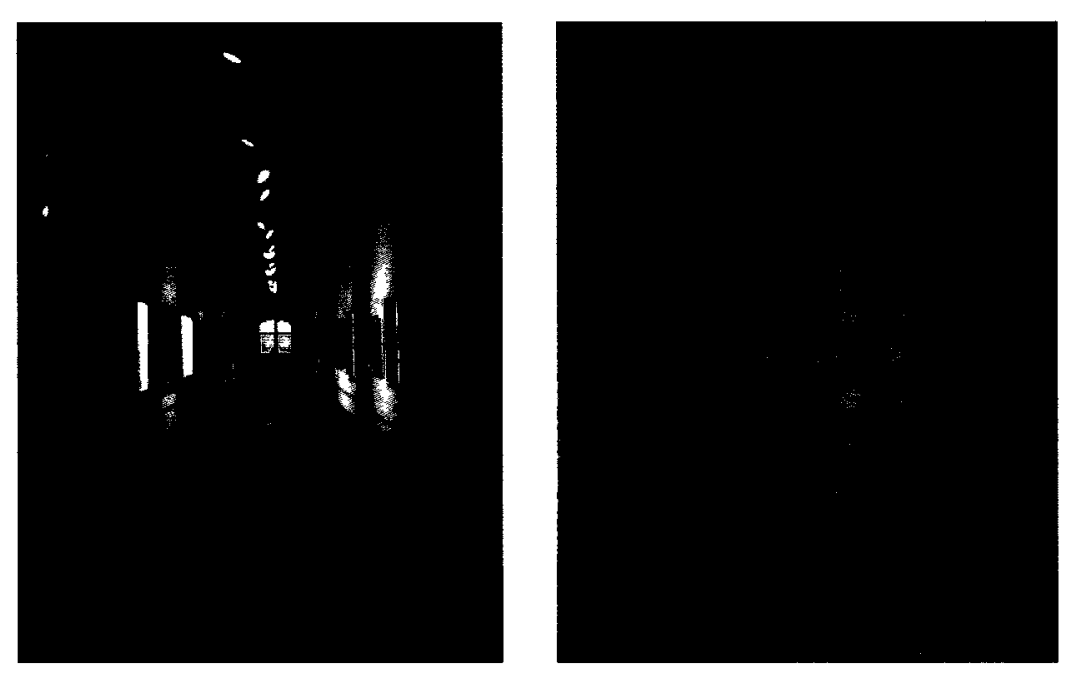

Viewing Gallery and Covered Windows, MFA, Boston (Photo: Wendy Quinlan-Gagnon 2010)

The original MFA building, outside and inside, imposes a sense of decorum on its visitors and maybe even a sense of exclusion on other would-be publics. At least one young acquaintance told me that he always felt intimidated by this building and rarely went there, even when living in Boston (Summer 2010). In addition, the MFA's roped-off ticket queuing area introduces another level of formality (not seen in the MoMA or Tate Modern). Ernest guards ensure that no-one puts a foot out of place-visitors are immediately directed to the cloakroom, told to leave their coats, briefcases, etc.; they are watched closely as they walk through the viewing rooms, pounced upon if they take out a camera and reminded not to use a flash. These unnecessary, and sometimes aggressive, interventions could certainly be felt as barriers by some potential publics. 
The MFA is not all solemnity, however. The West Wing, designed by I.M. Pei and opened in 1981, includes a long, open galleria, a cafe, a large shop and a two-hundred-and-twenty-foot glass ceiling, letting natural light flow into the museum and bringing a sense of modernity to the older building. A Japanese Garden, a central courtyard and a further extension, this one designed by London architects, Foster + Partners, in 1999, brings even more lightness to this side of the building as well as a second (glass enclosed) courtyard. The new Sharf Center, opened in 2008 , adds another popular space where visitors can relax or find information about the galleries and the exhibitions.

If, with Eco, we understand buildings as "communication" (Eco, in Leach, 2006, p. 182) and with Barthes as signs (Barthes, 1968) then, do these buildings and their interior ambiance send messages to their publics?
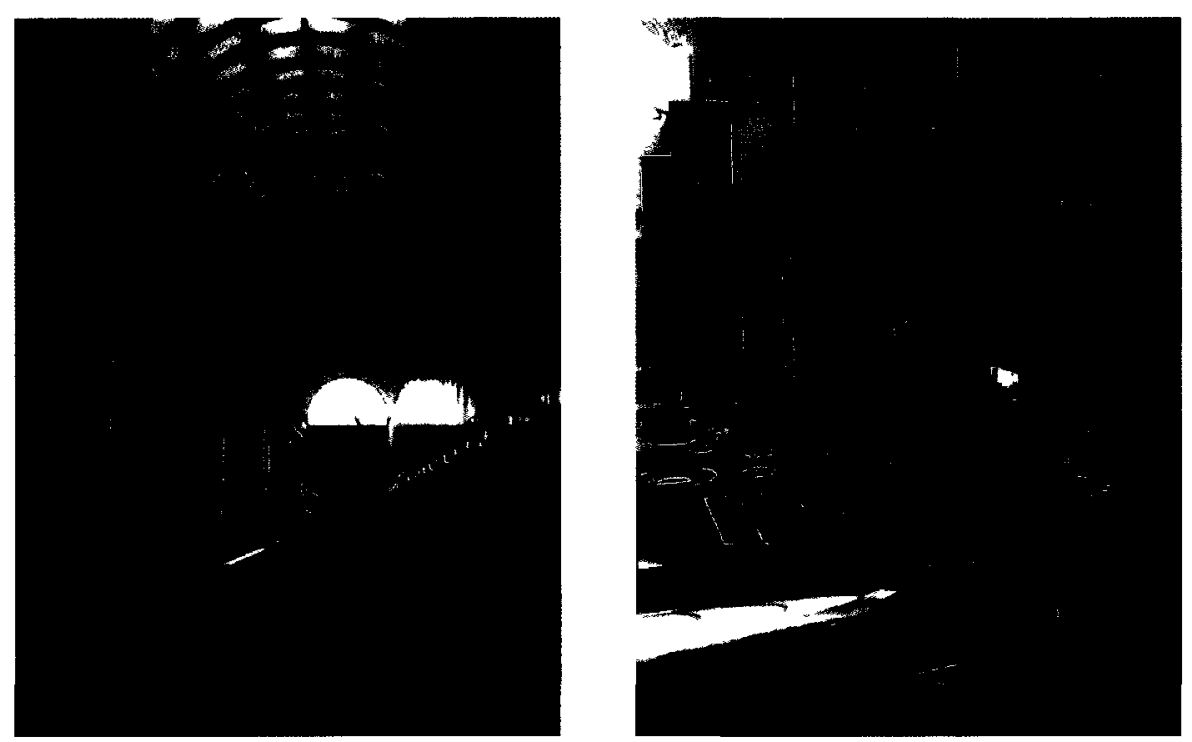

Two Views of the I.M. Pei Galleria, MFA, Boston (Photo: Wendy Quinlan-Gagnon 2010) 
It seems clear that both the MoMA and Tate Modern, with their easy access, their informal structures and their open spaces send the most welcoming messages (provide the fewest barriers) to the largest and most diverse audiences. We may even be able to say that the MoMA and Tate Modern exemplify the Kristevian semiotic text where multiple discourses occur, where multiple publics are embraced and where multiple approaches are initiated, while the NGC and the MFA remain Lacanian symbolic, name-of-the-father, transcendental signified texts (Pop Life notwithstanding). What I mean by this is that while French psychoanalyst Jacques Lacan advocates a symbolic order which is structured by language and by the laws and the social institutions which language guarantees (Lacan, 1977), Julia Kristeva advocates a more adaptable approach. She takes issue with Lacan's symbolic text saying it is too rigid, too patriarchal and too closed (Kristeva, 1980). Instead, she proposes a semiotic text which is more open, more flexible and more revolutionary-such as, for example, the poetry of Mallarmé or Lautremont. I would argue that the traditional museum with its rigid structure and top down approach could be seen as being synonymous with Lacan's symbolic text whereas the newer, more contemporary museums (the MoMA and Tate Modern, for example, or the Pompidou Centre in Paris ${ }^{87}$ ) with their openness, their interactive displays and their audience inspired activities are more reflective of Kristeva's semiotic text. This is not to malign the latter two museums, just to point out that, with their more formal structures and

${ }^{87}$ Although I refer to the Pompidou Centre here, it is not one of the case-study museums. 
their destination status, they send more official (and maybe even officious) messages to their potential publics.

Regardless of the buildings and of the internal ambiance in these museums, however, viewing protocols still have to be followed. Tate Modern and the MoMA with their open structures, atriums and gallerias, the I.M Pei Galleria at the MFA and the courtyard and garden at the NGC are both Panorama and Panopticon—both Bennett (1995) and Foucault (1975). By this I mean that these open structures both allow visitors to see each other (Bennett's repository of manners, 1995) and to be seen by the security mechanisms installed to keep them in place (Foucault's Panopticon, perhaps, 1975). Furthermore, all four museums impose different levels of security and watchfulness (lap tops and brief cases are allowed in the MoMA, but not in the MFA; security guards are very present in the NGC and the MFA, less so in the MoMA and Tate Modern, for example). Thus, the internal ambiance of these museum buildings seems consistent with the external messages their buildings send.

\section{Cafés, Bars and Restaurants and Shops}

Cafés, bars, restaurants and shops have become significant moneymakers ${ }^{88}$ for many art museums over the last 40 years. While stopping by the museum snack bar for coffee and a sandwich, or a cup of tea and a slice of cake,

\footnotetext{
${ }^{88}$ For example, New York News and Features reported in 2007 that the MoMA shop had sold over 100,000 copies of a book in seven different languages: MoMA Highlights, a collection of photos of 350 pieces of artwork generating over $\$ 2$ million for the museum (Cohen 2007, http://nymag.com/news/ features.) The British newspaper The Telegraph reported on 11 May 2010 that since opening visitors to Tate Modern book store had spent more than $£ 40$ million on books and $£ 35$ million on gifts, prints and postcards (Roya Nikkhah, The Telegraph, 11 May 2010)
} 
or picking up a few postcards in the museum shop may have been something visitors did in the past, today's museum goers are offered a huge range of entirely different dining and shopping experiences. Much of the food eaten in museum restaurants and many of the goods bought in museum shops are no longer strictly functional, however. Art museums have become places of consumption as well as places to view art. Their products (exotic foods and/or designer goods), may be sought after more for the meanings people give to them, or for the meanings they give to people, than for their actual "use value" in the traditional Marxist sense. Here I refer back to Preziosi and his observation that the modern subject believes that possessing and identifying with certain desirable objects (he calls it "stuff," Preziosi, 2003, p. 20) reflects and enhances his or her character.

An examination of this phenomenon is important to this study because of the role that both food and consumer goods play, or can play, as constructers and/or markers of social class. In his essay, "Toward a Psychosociology of Contemporary Food Consumption", Roland Barthes states that "[food] is not only a collection of products....It is also, and at the same time, a system of communication, a body of images, a protocol of usages, situation and behaviour" (Barthes, 1979, in Counihan and van Esterick, Eds. 2008, p. 29). He quotes from Lazarsfeld ${ }^{89}$ who suggests that certain tastes vary according to the income level of different social groups, with for example, the "lower" classes preferring sweet foods and the upper classes preferring bitter (ibid. pp. 30, 31). That is to say

\footnotetext{
${ }^{89}$ Barthes qualifies this reference to Lazarsfeld by saying that it is old and that he cites it only as an example (ibid. p. 30).
} 
that, according to Barthes, food signifies; it tells us something about the enterprise and about the people using it-likewise with consumer goods. Bourdieu, too, sees a distinction between the food eaten by the working classes and that eaten by the middle- or upper- classes, with the working classes opting for "substance" (pasta, potatoes, beans and pork) while the middle- and upperprefer "form" (beef, veal, mutton, lamb and especially fresh fruit and vegetables) (Bourdieu, 2002, pp. 177-200). Shopping also takes on a different meaning depending on what class one belongs to, with the middle- and upper-classes spending to enhance the quality of their personalities (Bourdieu, 2002, p. 281). Studying the eating establishments and the shops in public art museums from a semiotic perspective can help me determine what messages these institutions, as "means of communication," are sending to their various publics and what hidden barriers they might be putting in place to keep different publics apart..

All four of the case-study museums cater to multiple publics by offering many different eating options-from vending machines to kiosks to cafeteria-style food to bar services and fine dining. Their shops sell a variety of merchandise ranging from souvenirs, to books and posters, to expensive objets d'art. All of these institutions encourage visitors to eat in their restaurants or buy from their shops using specially targeted advertising that allows them (the visitors) to construct favourable images for and of themselves. The MFA restaurants, for example, appeal to people's emotions and to their sense of good environmental practices (locally grown food): 
Nestled among the grand masters of art and design in the Museum of Fine Arts, Boston, the dining venues from Restaurants Associates stir the senses with seasonally inspired menus and locally grown ingredients prepared throughout a variety of distinct dining venues (MFA Website).

And while the MoMA, the NGC and Tate Modern use more straightforward advertising, they also appeal to people's sense of their own (real or constructed) importance (the Michelin star at the MoMA, for example, which is associated with exclusiveness and fine dining and allows people to see themselves as elite participants in an elite social/cultural discourse):

MoMA features a variety of dining options created and operated by Danny Meyer's acclaimed Union Square Hospitality Group, including The Modern, a fine-dining restaurant that holds one Michelin star and three stars from The New York Times, and a pair of cafés, Cafe 2 and Terrace 5 (MoMA Website)

Tate Modern is a great place for lunch, dinner or drinks, with cafés and a restaurant and bar, all overlooking the River Thames, St Paul's and the City of London (Tate Modern website)

The National Gallery of Canada offers a range of food-service areas, each offering an interesting and unique variety (NGC Website).

All four museums offer a variety of venues and prices-a formal or semiformal restaurant, a café or cafeteria and a snack bar, kiosk or vending machine. 
The MFA's main restaurant, Bravo, is:

A work of art itself, with bold colors and clean lines, created by famed restaurant designer Peter Niemitz. The inviting, warm ambiance complements a rotating selection of some of the Museum's modern and contemporary masterpieces (MFA Website).

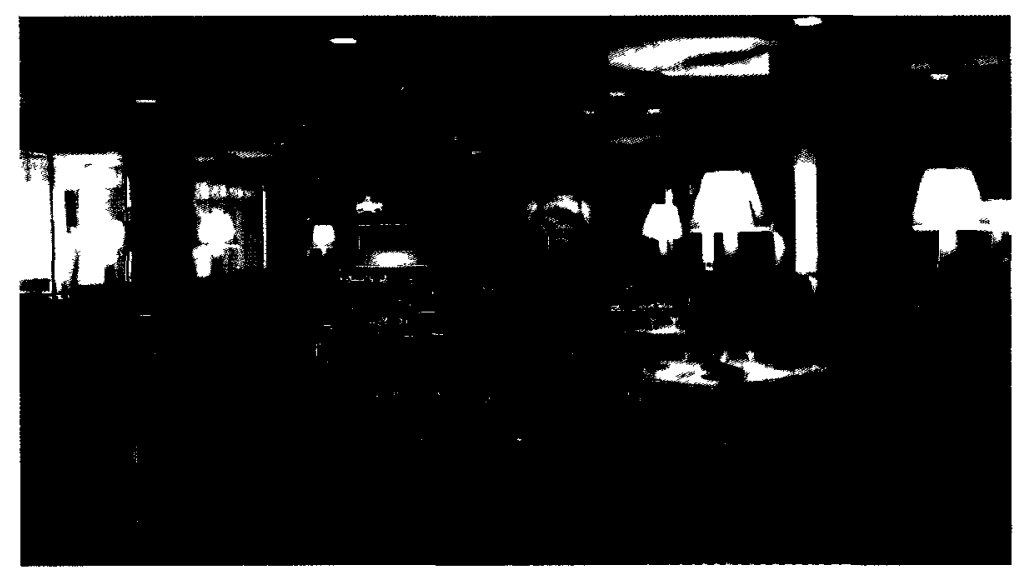

Bravo Restaurant MFA, Boston (Photo: Wendy Quinlan-Gagnon 2010)

Bravo offers "progressive American cuisine marked with an emphasis on seasonal inspired, local ingredients." Its ambiance is formal and refined, with soft classical music playing in the background. When I ate there in April 2010, the diners appeared to be middle-aged or older and, by their decorum, middle- to upper middle-class. There were no children in the restaurant.

The MoMA's main restaurant, The Modern, is quite the opposite of the MFA's Bravo. Where Bravo is quiet, The Modern is loud-loud voices, loud decor and loud rock/jazz music. Where Bravo is upscale demure, The Modern is upscale sophisticated. Where the food at Bravo is classical and wholesome (quiche and mixed green salad), the food at The Modern is daring and different 
(shaved asparagus with fava beans and arugula, for example). In April 2010, I found the diners at the MoMA restaurant. In 2010, participant observation showed diners at the MoMA restaurant to be younger and apparently more outwardly energetic than those at Bravo. Nonetheless, their stylishness and sophistication also branded them as middle- to upper middle-class citizens.

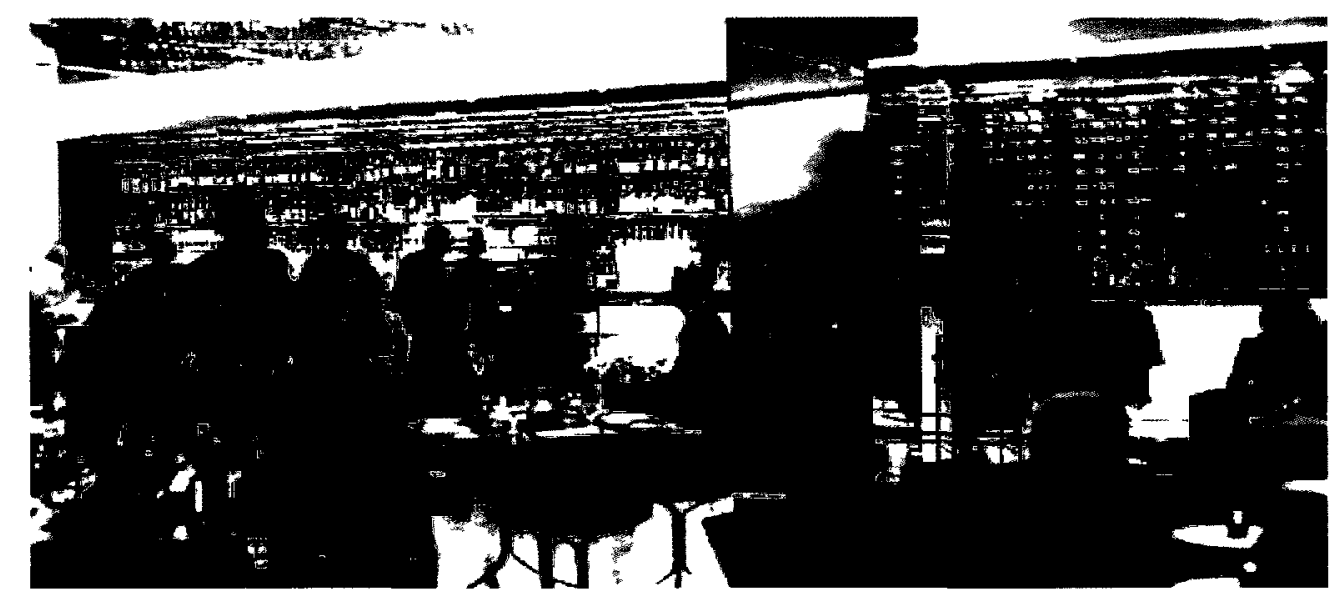

The MoMA Restaurant, The Modern (MoMA Website)

The Tate Modern Restaurant, located on level seven of the museum, offers a menu "based on fresh, seasonal produce together with an exciting wine list focusing on innovative producers."
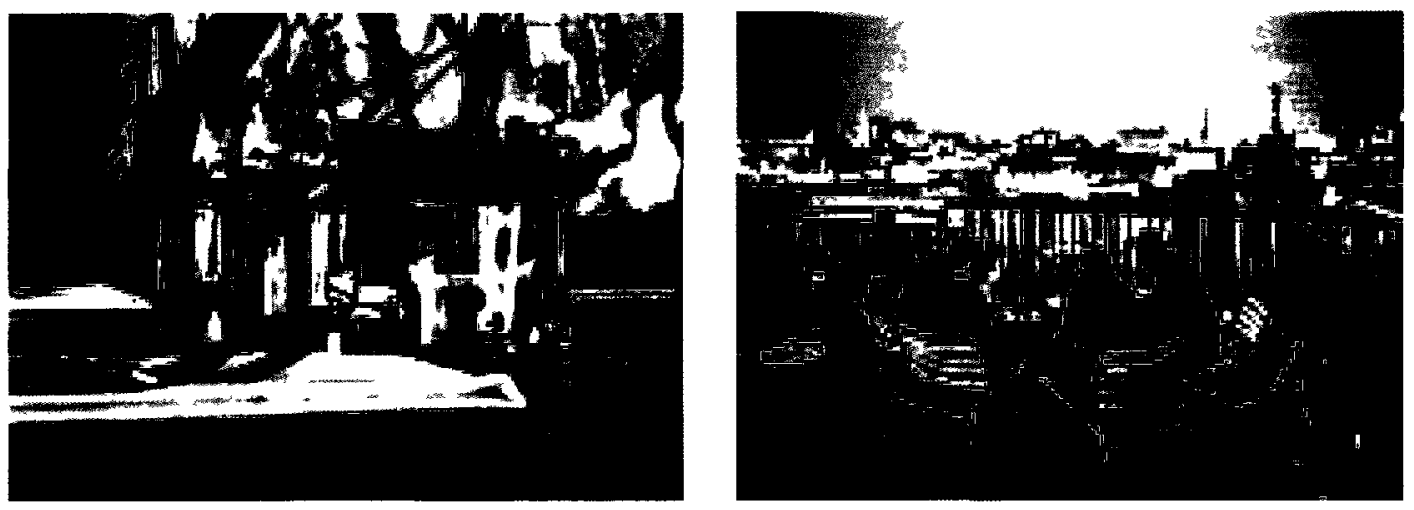

Tate Modern Restaurant (Tate Modern Website) 
Tate Modern Restaurant offers "menus which showcase quality ingredients, often sourced locally, but also taking the best from other countries, particularly Spain and Italy" and serving, among other things, "pickled radishes, toasted sourdough, Blacksticks ${ }^{\mathrm{TM}}$ blue butter and purple sprouting broccoli" (Tate Modern Website). These are exotic fare, more likely to appeal to the extraordinary rather than the ordinary visitor (Bourdieu, 2002).

The National Gallery of Canada's Café L'Entrée is the least formal of all the museum restaurants. Situated in the Great Hall, overlooking the Ottawa River, it serves "light foods and fine pastries" for lunch and afternoon tea. Its ambiance is relaxed and friendly, but the number of seats is limited. Its metal tables and small bouquets of flowers give it an air of elegance and its roped-off boundaries make it seem a little exclusive. Café L'Entrée is not open in the evenings for dinner.

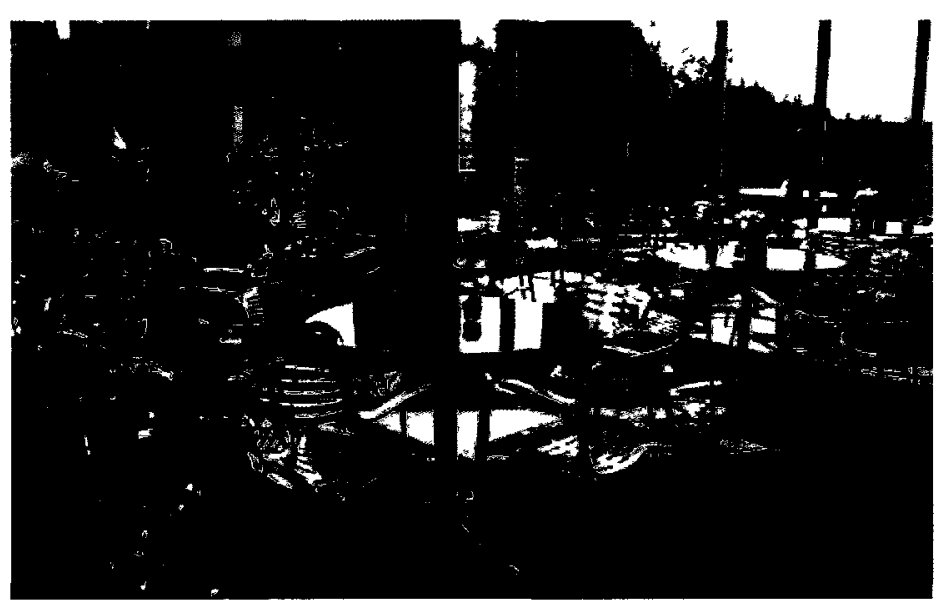

NGC Café l'Entrée, Ottawa (Photo: Wendy Quinlan-Gagnon 2010)

All four museums have secondary and tertiary eating establishments ranging from the classy Galleria at the MFA to the Espresso Bar at Tate Modern 
to the Sketches' vending machines at the NGC. The MFA Galleria, situated in the I. M. Pei-designed West Wing gallery, is said to evoke "the feeling of a Parisian sidewalk café" where diners "may people-watch as passers-by attend a film or lecture in Remis Auditorium or visit the Museum's galleries." The Galleria offers "light, contemporary cuisine featuring freshly made soups, signature salads and decadent desserts." This eatery, like the MFA Bravo, the MoMA Modern and the Tate Modern Restaurant creates barriers by being exclusive and expensive and it allows visitors to imagine themselves in an unreal world through the signs and labelling it uses (for example, being like a Parisian sidewalk café).$^{90}$

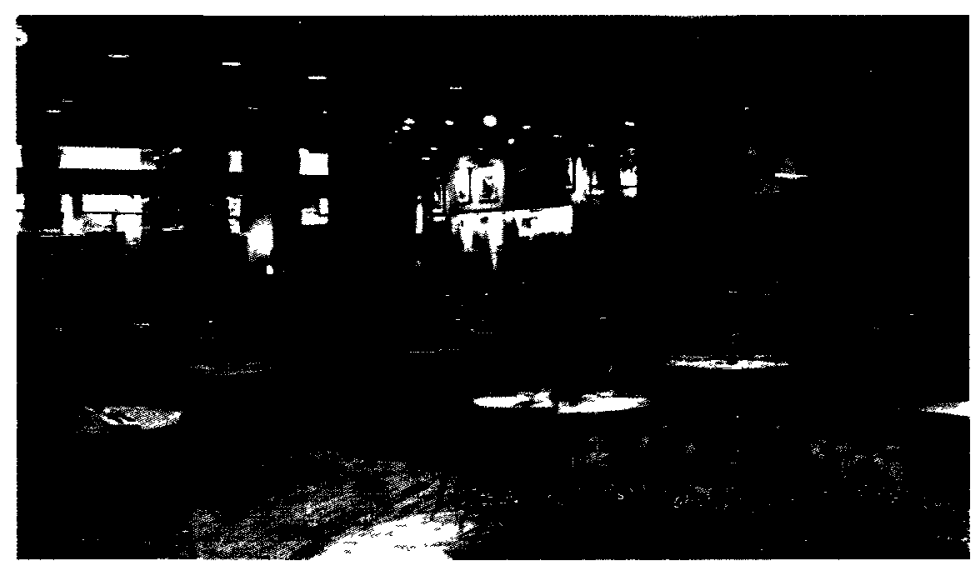

The Galleria, MFA. Boston (Photo: Wendy Quinlan-Gagnon 2010)

In contrast to Bravo and the Galleria, the MFA Courtyard Café offers sandwiches and salads for less than ten dollars and dessert for less than five. It is advertised as the most casual of the MFA's dining venues: "the Courtyard Cafe is the perfect destination for those who want a comfortable, family-friendly setting" (MFA Website). Offering these alternative eating opportunities may be a

\footnotetext{
${ }^{90}$ Although this image is evoked through advertising, the Galleria restaurant in no way resembles a "real" Parisian sidewalk café.
} 
sign that the MFA is trying to be more inclusive by recognizing its less affluent visitors, but it could also be seen as a barrier, relegating the less affluent to a small cafeteria-style restaurant hidden away on the courtyard level of the museum.

Tate Modern's Café 2 offers "a relaxed and friendly atmosphere [where visitors can] enjoy freshly baked scones with clotted cream in the afternoon, a carafe of wine on a Friday evening ${ }^{91}$ or a family lunch at the weekend", while the MoMA's Terrace 5 and Cafe 2 provide visitors with a range of foods, including "Panini, handmade pastas, salami, artisanal cheeses, salads, and soups" and an array of desserts, among other things. The NGC Cafétéria des BeauxArts "serves families and groups in an informal, self-service atmosphere." It offers two daily specials, a salad bar, and made to order sandwiches. Both Tate Modern and the NGC also offer vending machines and kiosks to supply visitors with convenient, instant snacks and cold drinks.

If Barthes is correct and food signifies ${ }^{92}$, then it is obvious that all of these museums go to great lengths, through their restaurants, bars, cafés, vending machines and kiosks to accommodate different publics. But more than that, upscale restaurants in these establishments provide some visitors with an opportunity to construct or reinforce their own (real or perceived) elite identitiesrather in the same way as wearing a Versace gown does (Preziosi, 2003, p. 20). Furthermore, I have noticed that the expensive, upscale, restaurants are always

\footnotetext{
${ }^{91}$ The expression, "on a Friday evening," is somewhat colloquial in contrast to the more formal language used to describe the Tate Modern Restaurant; one might wonder if that is because it is addressed to a less formal audience.

${ }_{92}$ By this, Barthes means that the type of food we eat tells people something about us.
} 
in the best locations, while snack bars and vending machines are tucked away, mostly out of sight-once again sending a subtle message that, despite all their attempts to reach out to a variety of different publics, these museums still put the highest value on their elite visitors, creating, perhaps, more subtle barriers to inclusiveness.

Even more than the food in the elite restaurants housed in these museums, however, the goods in their shops could be seem mostly as signs. By

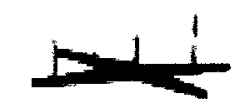

Eames' Chair $(\$ 9,475)$,

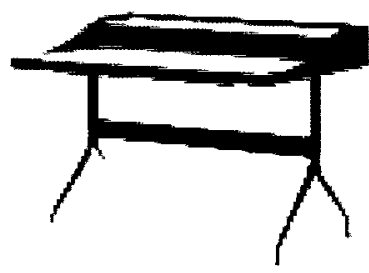

Nelson ${ }^{\mathrm{TM}}$ Swag Leg Desk $(\$ 2,055)$,

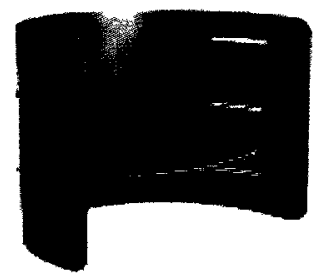

Child’s Chair $(\$ 590)$

that I mean that even items that would normally have some function (chairs, lamps, tables, etc.) might be considered as signs or signifiers first and only functional later since they are mostly "designer" items and often very expensive. Once again, I refer to Preziosi's claim that people buy expensive, designer items to enhance their own subjectivities (Preziosi, 2003, p. 20). This too could be a kind of elitism and a kind of barrier for the less affluent. That said, museums shops are often crowded, suggesting that once visitors are drawn into the museum, the shops do have something to offer them. The problem is, however, that many publics never come. 


\section{Conclusion}

This chapter has explored architecture, ambiance, cafés, bars, restaurants and shops at the four selected case-study museums. It has suggested, with Eco, that buildings, "built structures" communicate (op. cit.), and with Bathes that they are signs that send messages to their users and would-be users. Based on these and other theories, I have argued, for example, that while the MoMA and Tate Modern could be seen as exemplars of Kristevian semiotic texts (Kristeva, 1980, op. cit.), the MFA and NGC remain strictly Lacanian (Lacan, 1977, op. cit.). I have also suggested that the cafés, bars restaurants and shops at all four museums send hidden messages to their publics through architectural and other signs. By studying these buildings, viewing rooms, eating establishments and shops, I have been able to suggest that while these institutions continue to favour the elite and/or the would-be elite through a series of discursive practices (daunting architecture, unfriendly security guards, exotic food, expensive designer goods, for example), they are at the same time, to a greater or lesser extent, beginning to provide accommodation for less-experienced or lessknowledgeable publics. This is important to my thesis because it is here that I see a crack in the older, more traditional role of the art museum, allowing for a much needed move towards inclusion.

The next chapter examines the websites of the four case-study museums and suggests that they have a large role to play in helping individuals build the cultural capital they need to fully appreciate the art museum experience. 


\section{Chapter Five - Art Museums Online: Building Cultural Capital Using Interactive Websites}

\section{Introduction}

Websites are now a primary method of communication for most cultural (and other) organizations, large and small. However, like magazines and newspapers, if they are to be successful, they must follow certain protocols to ensure that users can easily find the information they need. Not only that, many website users are experienced and sophisticated surfers and have high expectations of both content and usability. Websites must communicate immediate value to their visitors at an intellectual level that is appropriate for them-otherwise they will go elsewhere.

This chapter reviews the websites of the four selected case-study museums to determine how well they speak to their prospective audiences. It examines the ways in which information is disseminated, images are juxtaposed and messages are written. That is, it tries to determine what part, if any, these museum websites might play in opening up their institutions and empowering their users-not only through the words and images they present, but also through the sub-texts they convey. To do this, I not only examine the websites themselves but also look back to see how some of the theories I have discussed earlier in this dissertation might inform the analysis of web content and usage.

Website analysis is not unproblematic, however. Many communication theorists have identified obstacles and methodological challenges facing 
researchers as they try to wade through the mass of information most websites provide (Gunter, 2000, Kim and Weaver, 2002, Stempel and Stewart, 2000). For example, the fluid nature of a website means that content is constantly changing. This makes it difficult to focus on any kind of quantitative analysis. In fact, Kim and Weaver (2002) have reported that most early web analysts avoided quantitative analysis altogether. Richard Hallett and Judith Kaplan-Weinger (2010) suggest that qualitative methods such as social constructionism (Carbaugh, 1996), critical discourse analysis (Wodak et al, 1999), mediated discourse analysis (Scollon 2001) and multimodal discourse analysis (Kress and van Leeuven, 2001) all provide excellent methods for examining websites (Hallett and Kaplan-Weiner, 2010, p. 6).

My approach in this chapter includes a mix of critical discourse analysis (CDA) and multimodal discourse analysis/semiotics. It draws particularly on the work of Kress and van Leeuven $(1996,2001,2006)$ who argue in favour of the multimodal approach: "Websites," they claim, "make meanings in multiple articulations" (Kress and van Leeuven, 1996, p.4). That is to say, they make the same meanings over and over again using different modes of communication (languages, images, sound, video, etc.) to emphasize their messages. Thus visitors need verbal, visual and aural literacy to manipulate these sites and enable them to enter at multiple points and navigate their own routes through or around them.

In their book, Official Tourist Websites: A Discourse Analysis Perspective, Hallet and Kaplan-Weinger (2010) suggest that websites serve both as "a setting 
for the initiation and incitement of social action" and as sites for the "construction of identities" (Hallet and Kaplan-Weinger, 2010, p. 6). If this is true, we might argue that these websites could contribute greatly to helping art museums become more inclusive, not only by allowing individuals to construct subjectivities for themselves as knowledgeable lovers of art but also by encouraging them to take the steps necessary to participate in the real as well as the virtual art museum experience. Thus, in this chapter, I look for messages (overt or hidden) of inclusion and/or exclusion by examining the different ways in which these websites speak to their real or potential audiences. I also examine them to determine to what extent, if any, they can serve to increase the cultural capital of their less knowledgeable publics.

This said I recognize the limitations presented by this kind of research: the problem of boundaries, for example, due to the endless amounts of information available on these websites, and the complexity of trying to interpret such multilayered, self-mediated data. Nonetheless, within the limitations of my research, I look for answers to two main questions: 1) Do art museum websites continue to perpetuate the same elitist discourses that other aspects of the art museum do? and 2) Can museum websites help to open up the art museum experience to wider audiences - that is, can websites attract people who would not usually enter the art museum complex? Or, in the words of John Cotton Dana, can they make "museums of art" much more inclusive by introducing new and different kinds of viewing (Dana, in Anderson, 2004) 
Bourdieu, Gans and others have argued that to enjoy the art museum experience individuals require a certain amount of cultural capital, obtained during childhood through family experiences and education, and usually (according to Bourdieu, 2002) restricted to the middle- and upper-classes. His studies on art museums and galleries (Bourdieu, 2004) have shown that many working class people, for example, not only do not like much of the art shown in contemporary galleries but also feel uncomfortable in such institutions. And, while later theorists (Lamont and Lareau, 1992, Boltanski and Thévenot, 1999, for example) have shown this to be not strictly true, we still do not see a full spectrum of citizens using our public art museums. That said, I would argue that since the introduction of the World Wide Web in the early 1990s, more and more people regardless of social background and/or income ${ }^{93}$ have access to more and more different kinds of information—including information about art and art museum activities. The Internet is now a major source of information for a large number of people (Internet World Stats, June 30, 2010).

\section{Home Pages}

Home pages, because they are normally the first encounter a user has with a site, have been called the most expensive real estate on the planet (Nielsen and Tahir, 2001). The home page sets the tone for the entire site; its layout, color and content will either attract or repel a potential viewer almost from the start. It is the "anchor" (Djonov, 2007). It articulates the mission and

\footnotetext{
${ }^{93}$ Although not everyone may be able to afford to buy a computer, many public libraries, schools and other institutions provide free access to, and free instruction on, the Internet.
} 
mandate of the organization and it reflects its values and ethical proclivities. If it is too sophisticated it will exclude possible users, likewise if it is too plain. If the language is too advanced, or if it is too simple, it will do the same. Its navigability will keep people interested if it is effortless, or frustrate them if it is complicated. Users must feel that a site speaks to them and, in the case of an art museum site, that it addresses their own personal social, cultural and educational needs.

All four of the selected case-study museum websites ${ }^{94}$ have vibrant home pages with rapidly changing mastheads at the top of their screens announcing one or more upcoming exhibitions. These mastheads are large and colourful and attract the user's eye. Information is disseminated either through dynamic links on the mastheads themselves (Tate Modern, the Museum of Modern Art and the Boston Museum of Fine Arts) or by hyperlinks on a side-bar menu (the National Gallery of Canada). The MoMA and the MFA also use horizontal links across the screen. These links make it easy for users to find facts about current and future exhibitions, past exhibitions, permanent collections, educational programs, research resources, opening and closing times, services and other museum activities.

\footnotetext{
${ }^{94}$ All images are screen shots from the four Websites being analyzed in this chapter. They were found at: www.gallery.cal, www.tate.org.uk, www.mfa.org, or www.moma.org.during the Spring/Summer of 2010.
} 


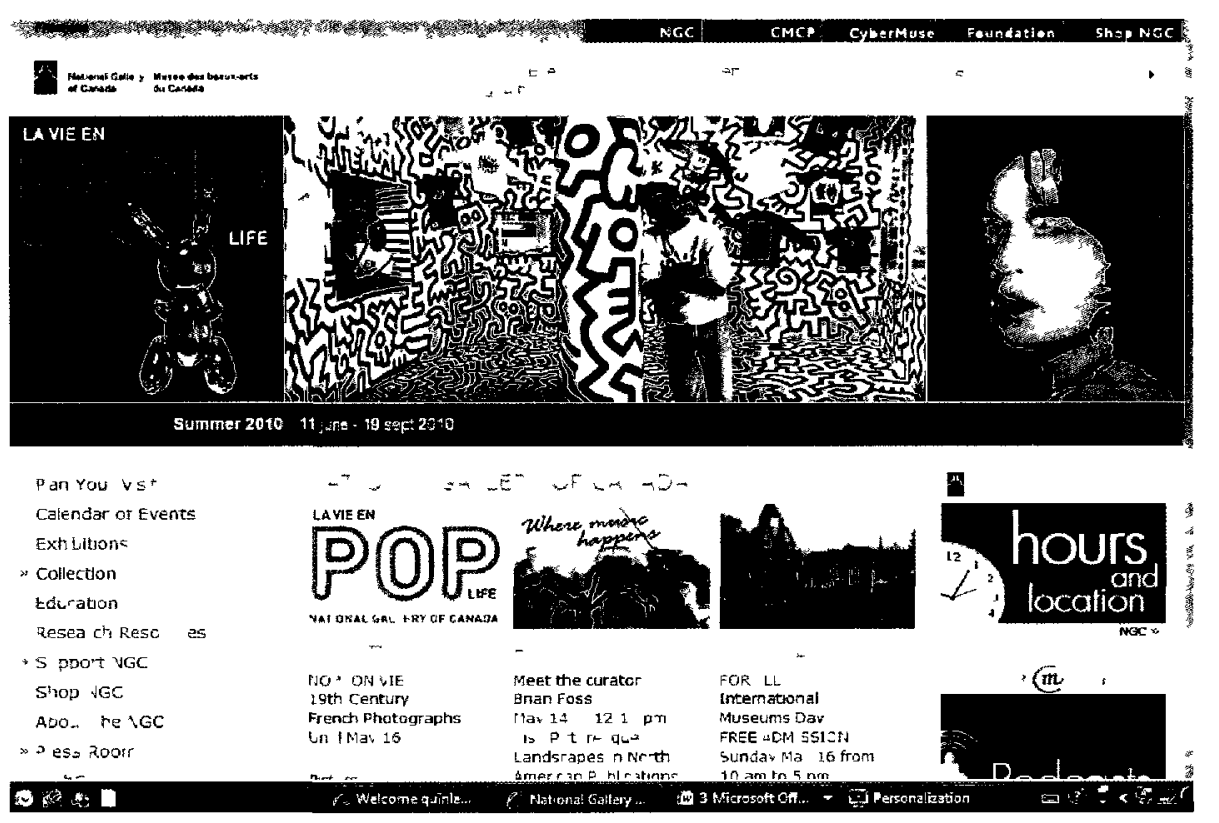

Natıonal Gallery of Canada Home Page, June 2010

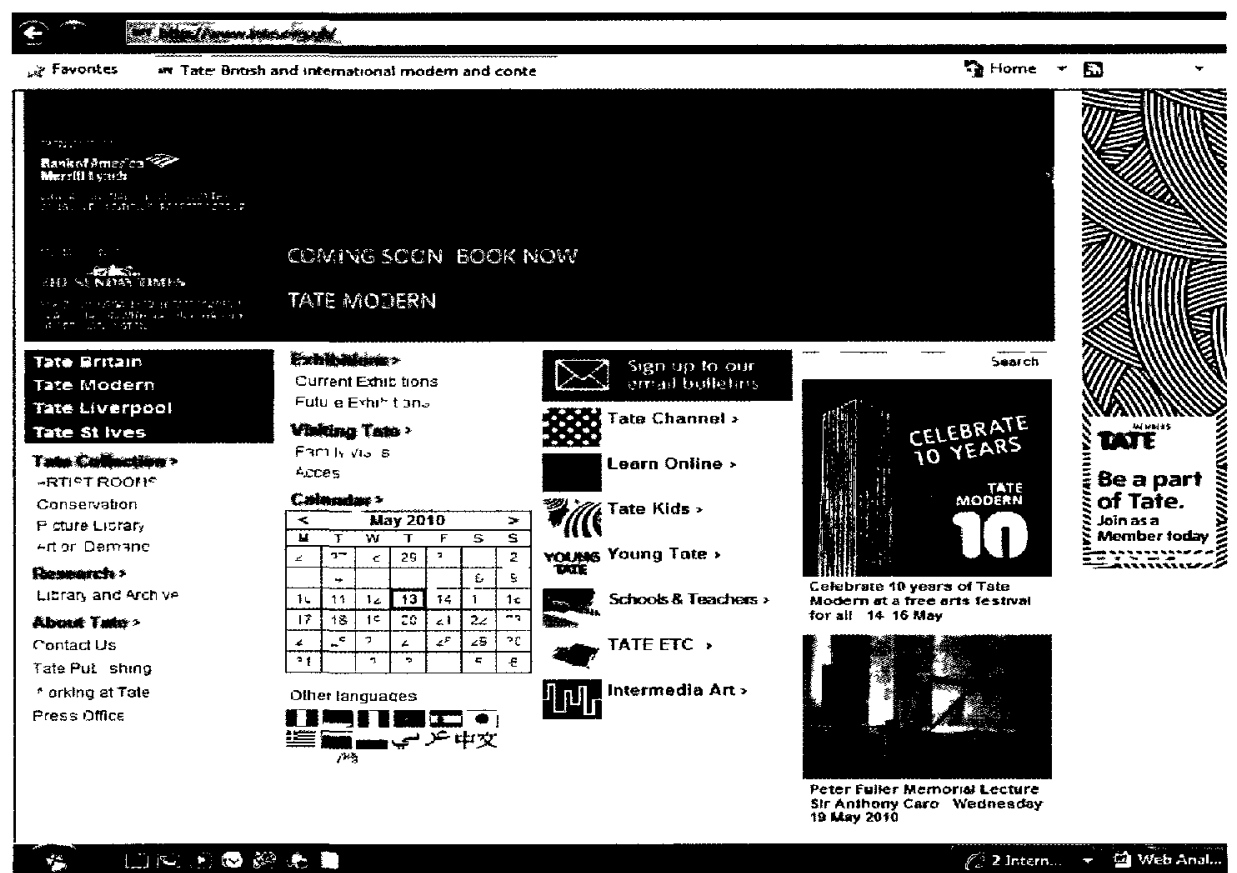

Tate Modern Home Page, June 2010 

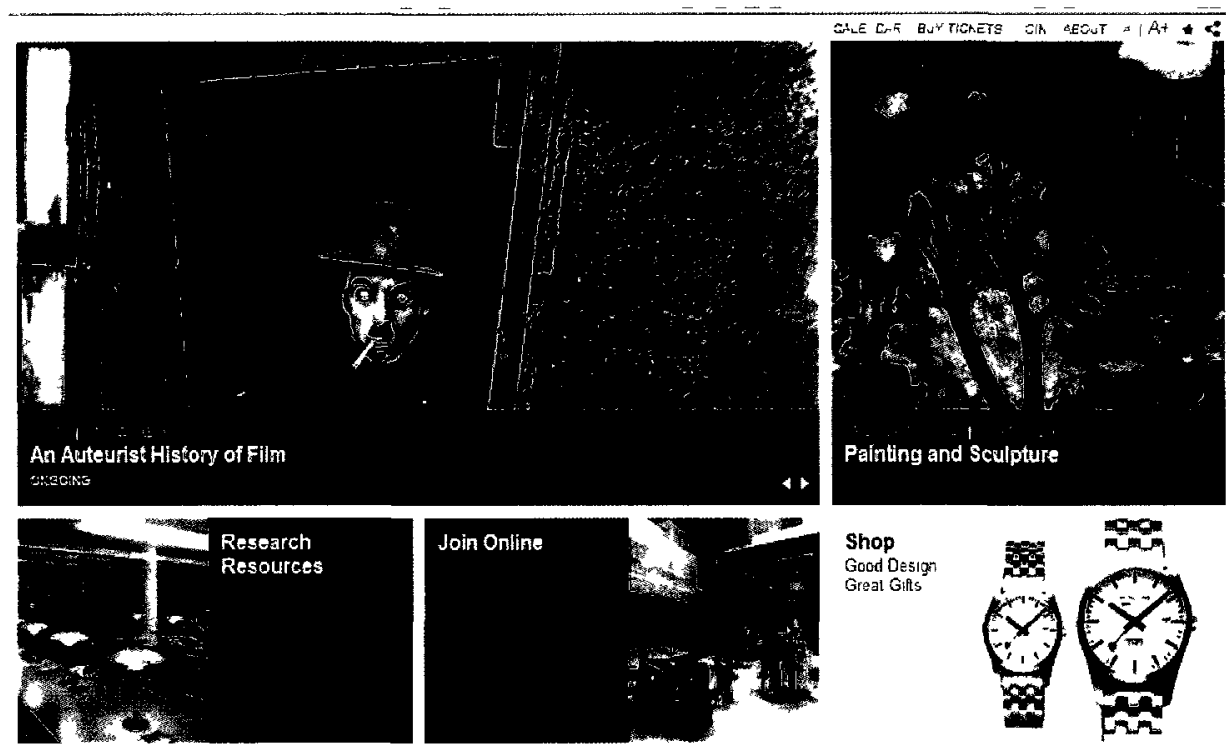

Today at MomA

On INSIDEJOUT- A MOMAP.S.1 Blog

The Amory Show 2010

110) VISIT EXPLORE LEARN SUPPORT SHOP

The Museum of Modern Art Home Page May 2010

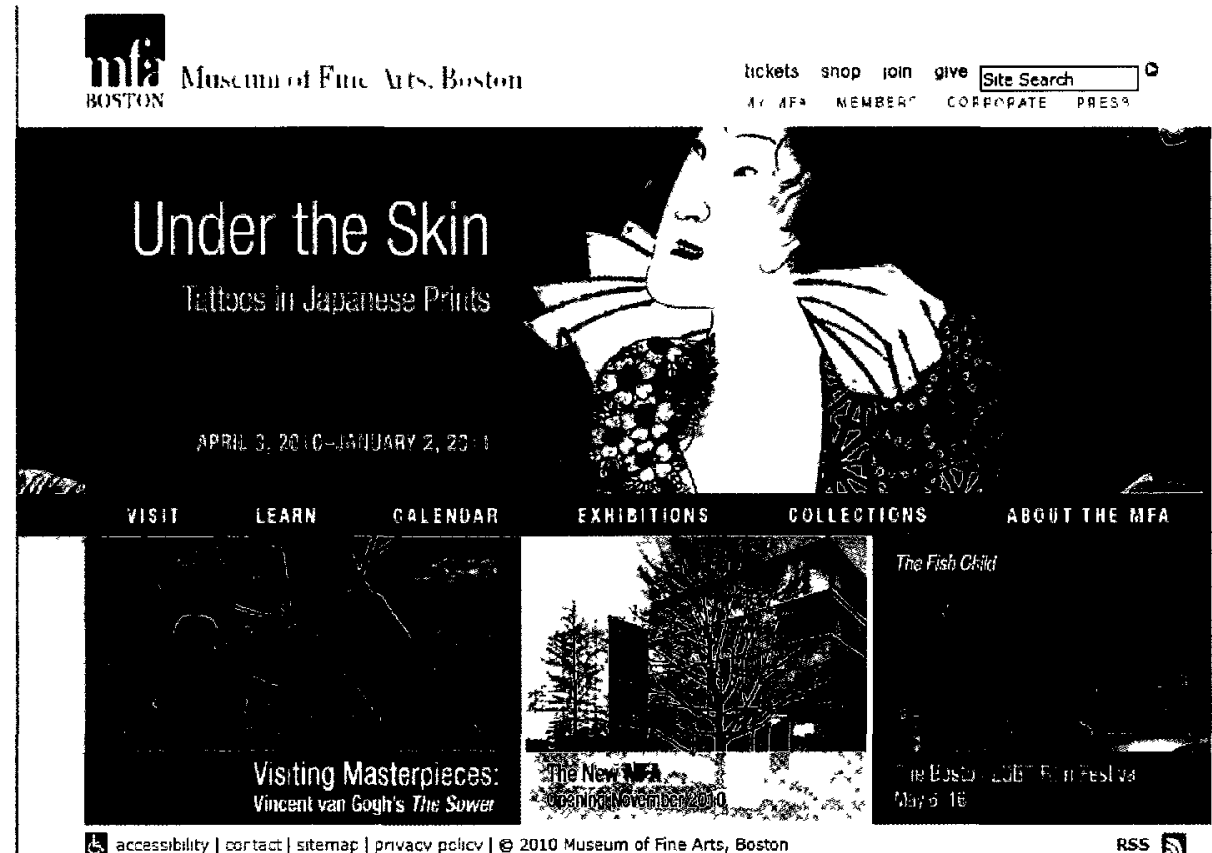

The Boston Museum of Fine Arts Home Page, June 2010 
All four of these home pages present clear, uncomplicated information that can be easily understood. They use visually compelling images that draw the viewer in. Hyperlinks for further navigation are clearly labelled. That said, exhibition posters or mastheads picturing unidentified artists on two of the sites (Warhol, Haring and Koons on the NGC home page to advertise "Pop Life" and Chaplin on the MoMA home page to advertise an "Auteurist History of Film," for example), could be considered exclusionary—with web designers or museum staff assuming that viewers would have the knowledge or experience to recognise the art, the artist or the film-maker without having them identified. This is a similar approach to the one used on the NGC magazine, Vernissage, and it speaks to a knowing audience. In fact, calling the MoMA film event an "Auteurist History of Film" could itself be considered exclusionary, as not everyone would be familiar with auteur theory or understand the meaning of the word "auteurist." These actions could constitute more of the barriers that may prevent some potential publics from enjoying the art museum experience, discussed earlier in this dissertation (Bourdieu, 2002, for example and Gans, 1999, among others).

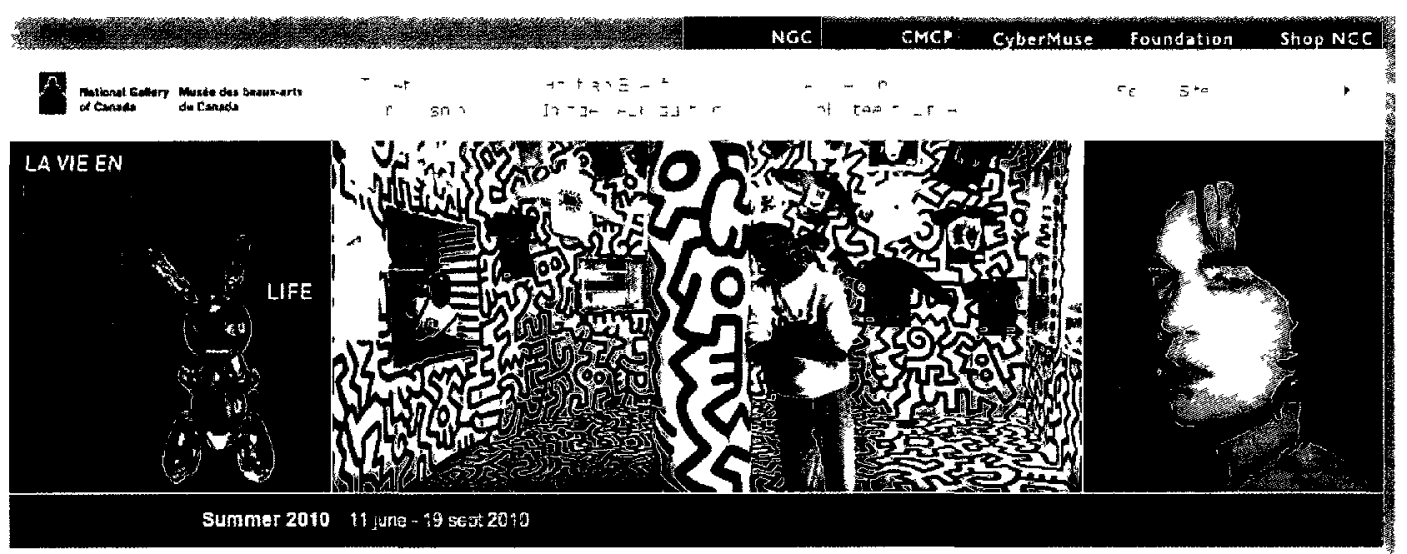

Koons, Haring and Warhol on the NGC (2010) Home Page 

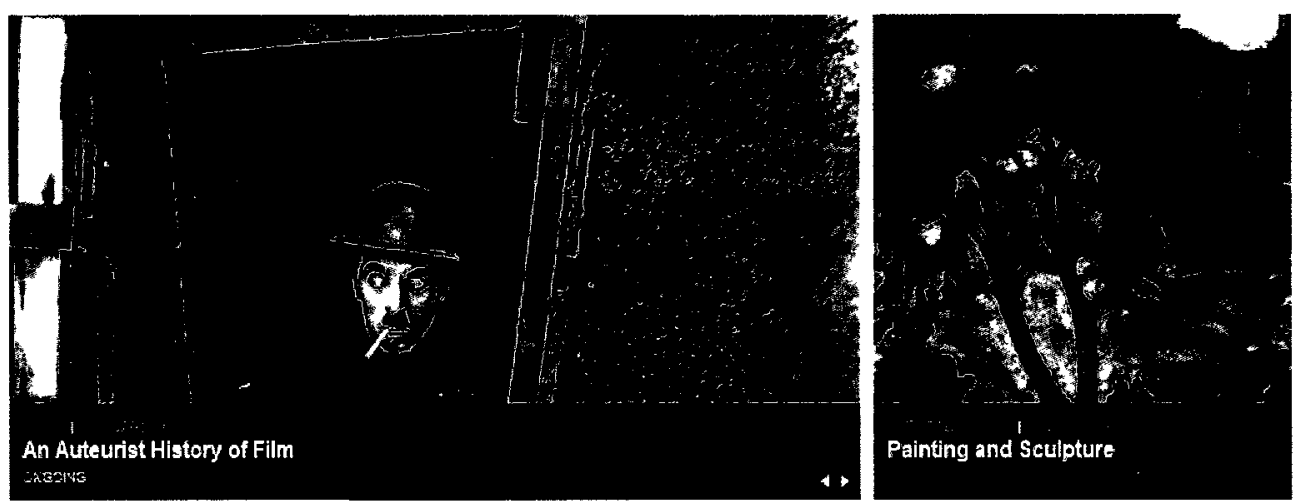

Chaplin on the MoMA Home Page, 2010

Tate Modern and the MFA Website home pages are more straightforward than the other two, providing the artists' names and information about the exhibitions on their mastheads. ${ }^{95}$

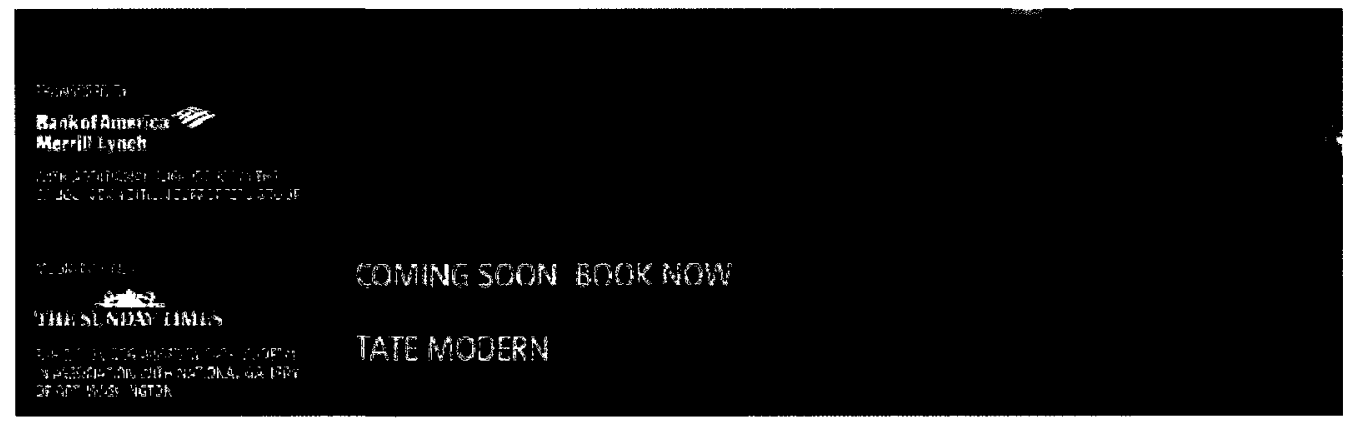

Gauguin at Tate Modern, 2010

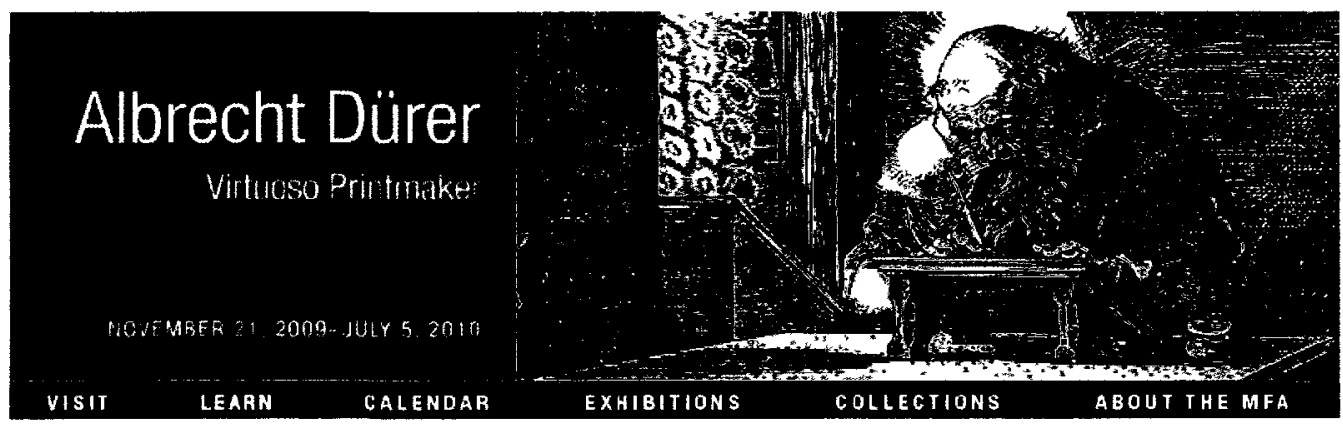

Durer at the MFA, 2010

${ }^{95}$ This is not to imply that Tate Modern or the MFA never follow the same practices as the other two museums. Neither does it suggest that the NGC and MoMA never identify the artists on their mastheads. 
On the whole, however, content on the four homes pages is helpful and readily accessible, although the NGC repeats information already on the side-bar menu on the main area of the page, making it redundant from a communication perspective. Also, the NGC home page is sparse, as most of the area is given over to hyperlinks to the embedded pages. This gives the screen a pleasing aesthetic but may not provide the services that users are looking for-many web users want information at their fingertips and resent having to hyperlink for it. Furthermore, neither the masthead nor the images announcing upcoming exhibitions or activities on this site are dynamic-unlike those on the other museum homepages. In addition, this site sometimes breaches home-page usability guidelines by requiring users to click through two or even three pages to find content they need. Nonetheless, the NGC home page received over $5,000,000$ "visits" in 2006-2007 and over 13,000,000 in 2007-2008 ${ }^{96}$ (NGC Annual Report, 2007-08, p. 40). The Gallery's online resource, Cybermuse, received over $50,000,000$ visits (ibid.). This shows that a lot of more people are interacting with the Gallery than would be possible without the website. ${ }^{97}$

In contrast to the NGC home page, content on both the MFA and MoMA home pages consists almost entirely of pictures-the only textual information being the dates of current and upcoming exhibitions. This makes these homepages seem especially user friendly and inclusive, particularly for individuals with limited reading skills. However, the pictures on the MFA home

\footnotetext{
${ }^{96}$ These numbers include the Canadian Museum of Contemporary Photography and the NGS Shop Websites.

${ }^{97}$ It is possible, of course that some people will visit more than once but, nonetheless, these numbers show very high usage.
} 
page appear to be random as there are many simultaneous exhibitions showing at the museum that are not pictured here-forcing the viewer to search deeper inside the site for missing information and perhaps leaving him or her unaware of many events. Pictures on the MoMA home page show selections from all the current exhibitions; however, the arbitrary juxtaposition of these constantly changing images makes it seem cluttered.

Tate Modern home page consists almost entirely of links, although a lot of useful information is available at a single click of the mouse. A picture of the museum building as well as a detailed floor plan, for example, is available beneath the masthead, allowing visitors to plan their way around the building before they even arrive. This could be useful for dispelling discomfort some visitors might have about arriving at an unknown destination—especially an art museum. Allowing them to get to "know" the building before entering-i.e. "where to go" and "what to do" ${ }^{98}$ — could help to increase their confidence and elicit a feeling of inclusion. In other words, it may help them to create an identity for themselves that depicts them as people comfortable within the art museum environment. This is explored more fully in the "visits" section of this chapter.

From a usability perspective, there are a number of anomalies on all four home pages. ${ }^{99}$ The NGC Website uses a "routing" page ${ }^{100}$ in front of the home page, although routing pages are not recommended in web-usability protocols;

\footnotetext{
${ }^{98}$ The reference here is to Boltanski and Thévenot (1999) discussed earlier in this dissertation.

${ }^{99}$ For example, information located above the banner-which is not recommended, search boxes in hard-to-find places, horizontal scrolling, clicking through multiple pages to find information, broken or misdirected links, etc.

${ }^{100}$ A routing page is a page that provides users with alternative home pages.
} 
However, in this particular case routing pages seem acceptable, since the options here are for English or French, Canada's two official languages. That said, the other sites offer information in a large variety of languages as well as English and French, including Chinese, German, Spanish, Portuguese, Italian, Arabic, Japanese and Russian-not available at the NGC.

Only the NGC has routing pages. Tate Modern has a selection of national flags on its home page. Clicking on a flag changes the language-making it very easy for users to select their language-of-choice. This communicates a message of inclusion, i.e., that all are welcome. The MoMA has a drop down "languages" menu, but it is entirely in English-perhaps making it difficult for some nonEnglish speaking visitors. Users of the MFA Website must click on "visit" to find their language options, and may miss them altogether if they decide to go straight to the exhibitions' screen. These features can all contribute to feelings of inclusion or exclusion both on the site and beyond it. If users are unable to see themselves in the discourses of the website, they are more likely to feel excluded and less likely to participate in the art-museum experience.

Unlike the NGC and the MFA home pages, the MoMA and Tate Modern home pages also display dynamic pictures of goods from their shops. While the items from the Tate Modern shop are quite discreet, the large picture of watches used to advertise the MoMA shop seems out of place on an art museum sitesending a signal, perhaps, that shopping is just as important as viewing at this institution. And since these are "designer" watches, all relatively expensive, this also reinforces the idea that the museum is targeting individuals from a certain 
income bracket, perhaps sending another subtle message of exclusion (Bourdieu, 2004) to its less wealthy visitors. Overall, however, these home pages provide a series of dynamic points of entry into the sites. I say "points of entry" because a website, unlike a more traditional mode of communication (a book, for example), offers the user multiple ways of navigating or mining the information provided. Some of these ways are explored below.

\section{Embedded Information-Something for Everyone?}

The amount of embedded information on these websites is prodigious. This section of the chapter does not, and could not, attempt to analyze everything. ${ }^{101}$ Rather, it provides an overview of some of the main categories linked thematically (visits, exhibitions, children and teens) and focuses on representative samples of texts and images to try to determine whether or not there are overt and/or hidden messages of inclusion or exclusion on these pages. Keeping in mind Hallet and Kaplan-Weiner's comments that websites allow individuals to construct identities that lead to social action (2002), I examine these sections to determine just what kinds of identities are available to potential users and how constructing those identities might empower them to participate in the art museum experience.

\section{Visits}

If, as Bourdieu's research claims, many individuals have feelings of unease inside cultural institutions such as art museums-which may even

\footnotetext{
${ }^{101}$ For a more complete overview of the material on these websites, see the "site maps" in Annex B.
} 
prevent them from visiting-perhaps these websites can help to dispel any unease visitors might feel by facilitating a sense of familiarity with the layout and services before they even visit the museum. A look at the "visits" pages of the four case-study museums selected shows how this might happen. All four museums have a "visit" or "plan your visit" link from their home pages that are very user friendly for potential visitors. They have secondary links to more tips for visiting —including: collection displays, past, present and future exhibitions, films, concerts and educational programs as well as museum-based restaurants, bars and cafés. There are links to buying tickets online and to information for visitors with disabilities. These websites also provide street addresses, telephone numbers and email addresses as well as telephone phone numbers for the ticket office, for education group bookings and for recorded information. They provide detailed instructions, including maps, of how to get to the museums using both private and public (Tate Modern) transportation.

These are all features that deliver solid, useful information about the museums. And, if we consider this from a "multiple modes of communication" perspective, we might say that a potential visitor to Tate Modern, for example, could log on to the website, read about the museum, see a two-dimensional picture and a map or floor plan of the building, use the mouse roll-over feature to get more information about the floors and the works on each floor, take a three dimensional virtual tour of the museum and generally become familiar with the layout of the building. Links from some of the floors or works of art will take this visitor to a new page featuring written information about the artist, pictures of the 
works being exhibited and perhaps even a video of the artist discussing his or her work. Similar but less sophisticated virtual tours (NGC) and floor plans (MFA, MoMA) are offered by the other three museums. This composite approach speaks to inclusion and allows visitors to plan their visits before they arrive. More than that, though, it seems possible that by allowing unsure or timid $^{102}$ visitors to browse the museum facilities in the safety of their homes or schools or libraries (for example), museum website "visit" pages can help them overcome any reluctance they might have about visiting or participating in art museum activities—rather in the same way that Tate Liverpool's "taxi" program, discussed in Chapter One, gave taxi drivers the confidence not only to spend time in the art museum but also to talk to their clients about the exhibits, perhaps disproving Bourdieu's theory that working class people do not like most of the art in contemporary art museums.

Furthermore, if we accept Boltanski and Thévenot's theory that people are judged by "plural orders of worth"-that is, that a person's worth is constantly determined and re-determined by how he or she reacts in different situations, we might be able to argue that having a strong understanding of "where to go" and "what to do" in certain social and cultural situations (in this case in visiting art museums) might inspire potential visitors to walk through the door.

${ }^{102}$ Bourdieu describes the timid person as "someone who is uneasy in his body (Bourdieu, 2002, p. 207). 


\section{Exhibitions}

If the "visits" pages on these sites can help apprehensive visitors develop a sense of familiarity with museum layouts and services before actually visiting and give them an extra sense of confidence in their knowledge of visit protocols, it is also possible that the "exhibition" pages can provide the same people with some much-needed cultural capital. ${ }^{103}$ All four sites provide detailed descriptions of upcoming and future exhibitions-dates, times, locations, etc.-but more importantly, they provide information about the artists and their works. For example, if during the summer of 2010 , a potential visitor had wanted to find out about the Pop Life exhibition on view at that the National Gallery of Canada, she or he could have gone to the NGC website and found an almost unlimited amount of information about the exhibition. Not only were there written descriptions of the works on view, but there were also, videos, music, artists' bios, pod casts and pop primers as well as a link to "Pop Life on YouTube" and, more importantly, a link back from YouTube to Pop Life. ${ }^{104}$ In addition, a visitor could have visited a virtual version of the Pop-Shop ${ }^{105}$ and bought Pop Life brica-brac.

This multimodal approach to communication was designed to speak across generations, reaching out not only to traditional gallery goers but also to young people of many different backgrounds and interests. Here we saw the

\footnotetext{
${ }^{103}$ Of course, knowing "where to go" and "what to do" in the museum could also be considered a kind of cultural capital.

${ }^{104}$ Many people who use YouTube may not think of going to the exhibition, but may be encouraged to do so once they are introduced to it through this link.

${ }^{105}$ Pop Artist Keith Haring opened the Pop-Shop in downtown Manhattan in 1986 as an extension of his work to ensure that his art "could be accessible to everyone" (Keith Haring Website). A replica of the original Pop-Shop was installed in the NGC for the duration of the exhibition.
} 
National Gallery of Canada stepping out of its conventional role to capture a more diverse audience, first by staging this exhibition and then by using new technologies to attract a variety of different audiences. ${ }^{106}$ Reaching out and empowering people through its website may have worked very well for the NGC in this particular instance. ${ }^{107}$

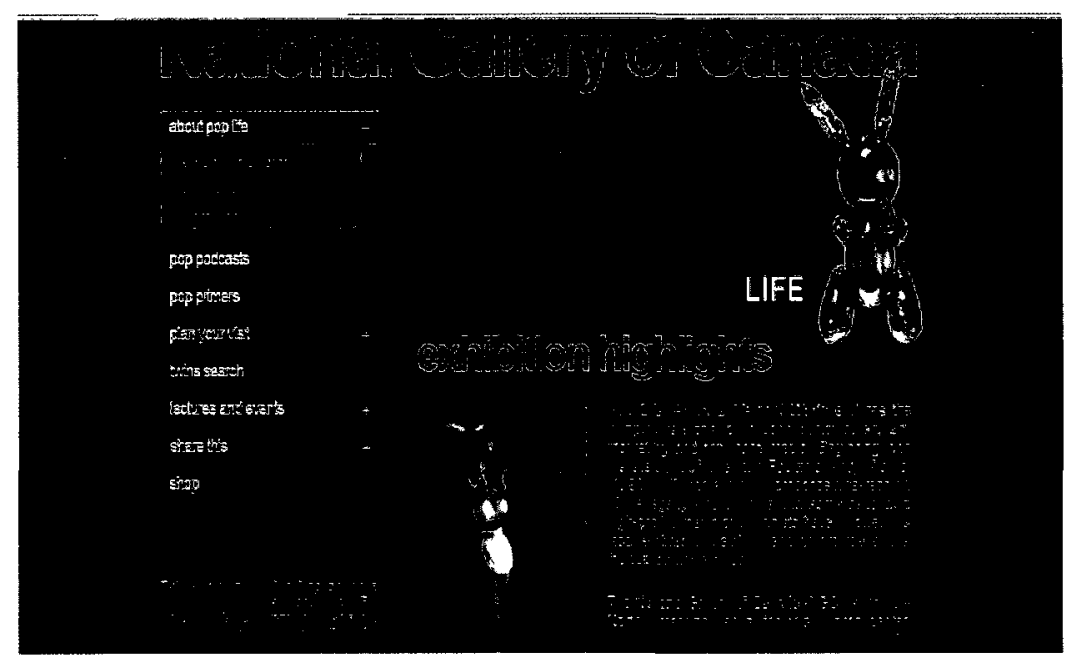

Pop Life on the NGC Website, Summer 2010

Similar acquisitions of knowledge and power can be gained by individuals using any of the other three websites. For example, Gauguin at Tate Modern (September 2010 - August 2011) and Toulouse Lautrec at the MFA (November 2009 - August 2010) and Burton at the MoMA (November 2009 - April 2010), all provided large amounts of information about the artists and their work. The Burton exhibition in particular allowed its visitors to log on and watch films, (by and about Tim Burton), listen to music, and view Burton cartoons, sculptures,

\footnotetext{
${ }^{106}$ The assistant curator, Jonathan Shaughnessy reported that a record number of people attended the Pop Life exhibition with over 67,000 visitors. The Gallery was hoping for 45,000 , (www.obj.ca, October 2010).

${ }^{107}$ More research is needed to determine exactly what influence, if any, the website actually had on the increased numbers of visitors.
} 
sketchbooks, posters, texts, etc.-all interactive and very empowering. The Burton site was still available on the MoMA Website one year later.

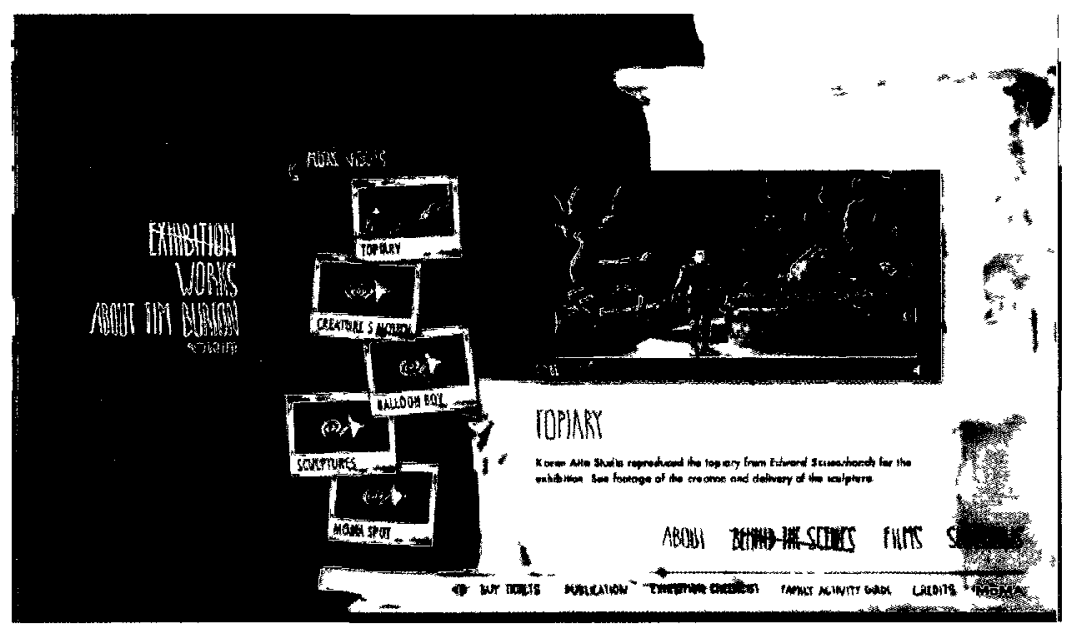

The Burton exhibition advertised on the MoMA Website, $2009-2010$

A visitor so inclined, then, could become quite knowledgeable about an artist or an exhibition before even going to the museum-thus increasing his or her "feeling of worth" according to Boltansky and Thévenot's model, and developing a keener sense of agency through "individually determined action"as described by Rosengren $(1995$, p. 14). At this point we may also be able to say that this person has increased his or her cultural capital directly through the use of the website-even without former knowledge, education, wealth and social standing. However, more research is required to determine if this is true.

\section{Children and Teens}

One way to foster a love of art and a feeling of inclusion is to make art museum activities available to children from a very young age. Since searching the Web for information is a popular pastime for many young people, this section examines how the four case-study museums use their sites to keep young 
viewers engaged. The NGC, for example, uses its website to announce programs for children and teens, but it does not have a specific children's website. The MFA, on the other hand, has "Art Connections" on its website and invites parents to share the Web with their children to discover information and complete activity sheets on a variety of topics and approaches.

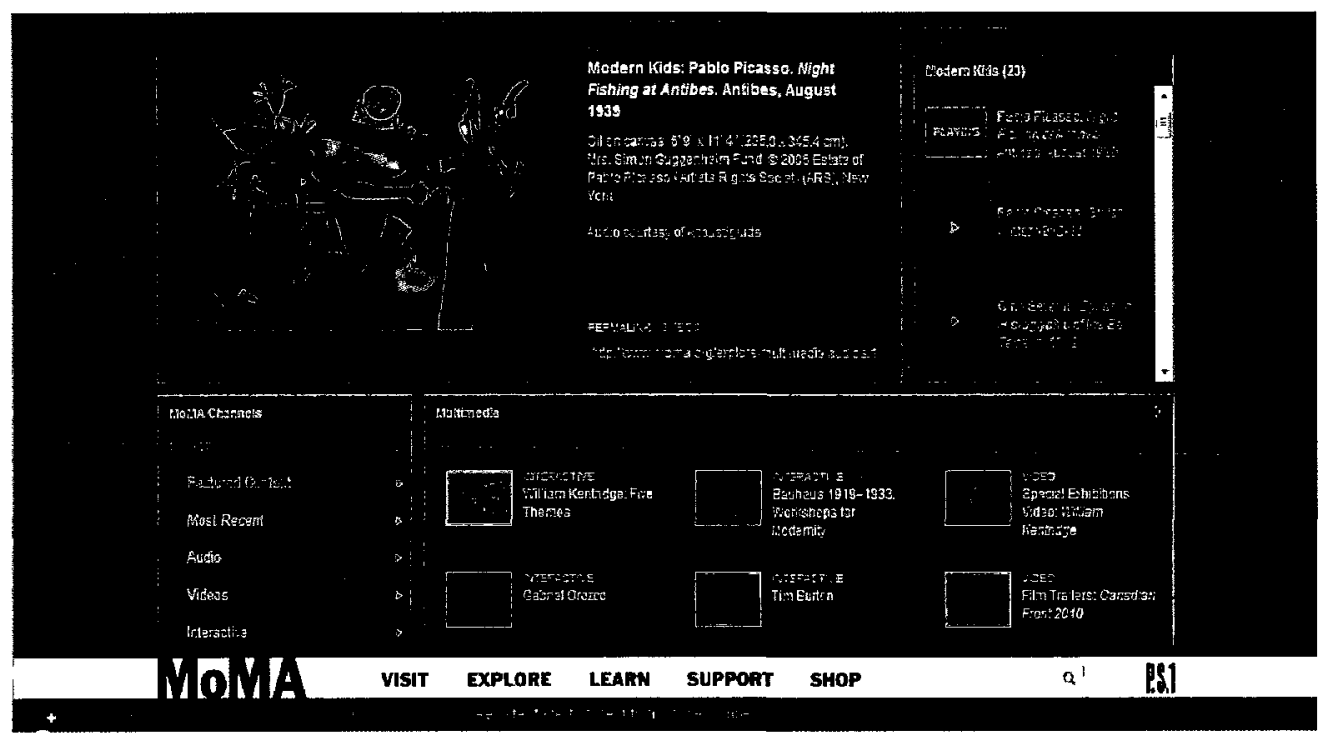

MoMA Audio: Modern Kids

The MoMA Website contains a lot of information about teen and children's programs; it also has a special multimedia site for children called "MoMA Audio: Modern Kids" (which provides detailed information on paintings by a number of different artists) and "Destination Modern Art: An Intergalactic Journey to MoMA and P.S 1" takes children on an animated journey through the museum. 


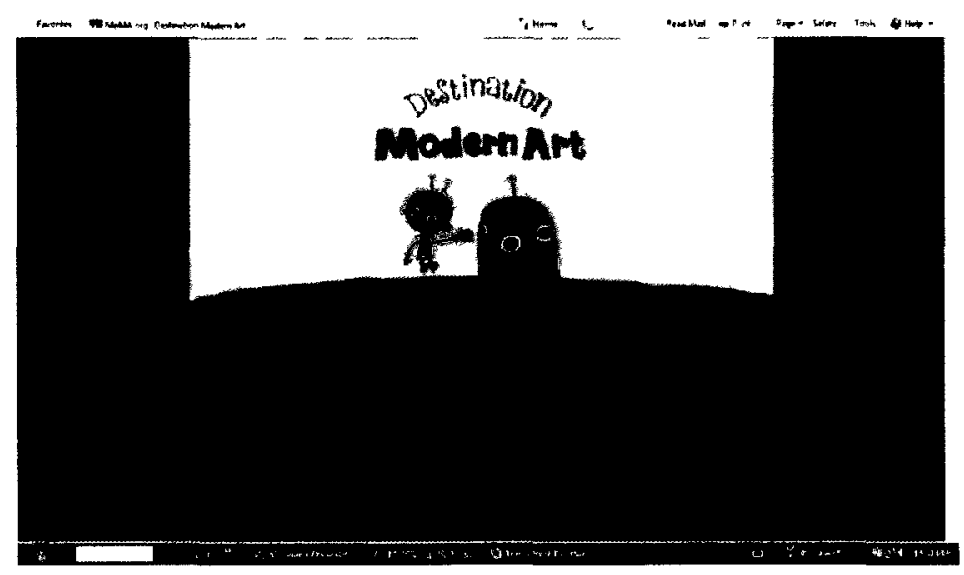

Destination Modern Art: An Intergalactic Journey to MoMA and P.S 1

Tate Modern has an extensive array of activities for children on its Tate Kids Website. These include games, films, craft activities, colouring books, ecards and a Tate kids online safety guide. These are all initiatives that can help children grow up with a sense of "comfort with" and "belonging to" the art museum world. During my research and throughout this dissertation, I am taking the position that participating in the arts in general, and visiting art museums in particular, can be an "enriching experience" (Deitch, 2010, Halbreich,2010, Nussbaum, 2010).

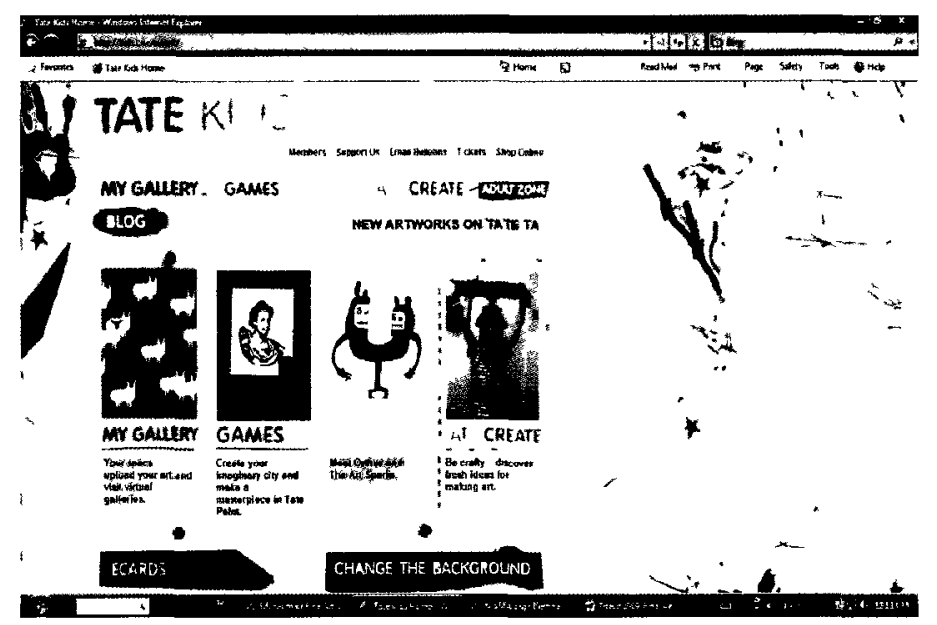

(Tate Kids Website) 
In addition, "Young Tate" is a dynamic website for teens that provides information on art, artists, design and museum projects as well as help with exams. It, too, has games and "challenges." It also has information on careers. It is a site that brings the art world to its audience in an interesting and stimulating way. This is important because, of all age groups, teens are the most difficult group to attract-for museums in general, and for art museums in particular (Lemerise and Soucy, 1999, pp. 355-368). Reaching out to them through a dynamic website might be one way of getting them interested in visiting the museum and, as with older people, the knowledge they can gain through using these websites can add value to their lives in many different ways (Deitch, 2010, Nussbaum, 2010).

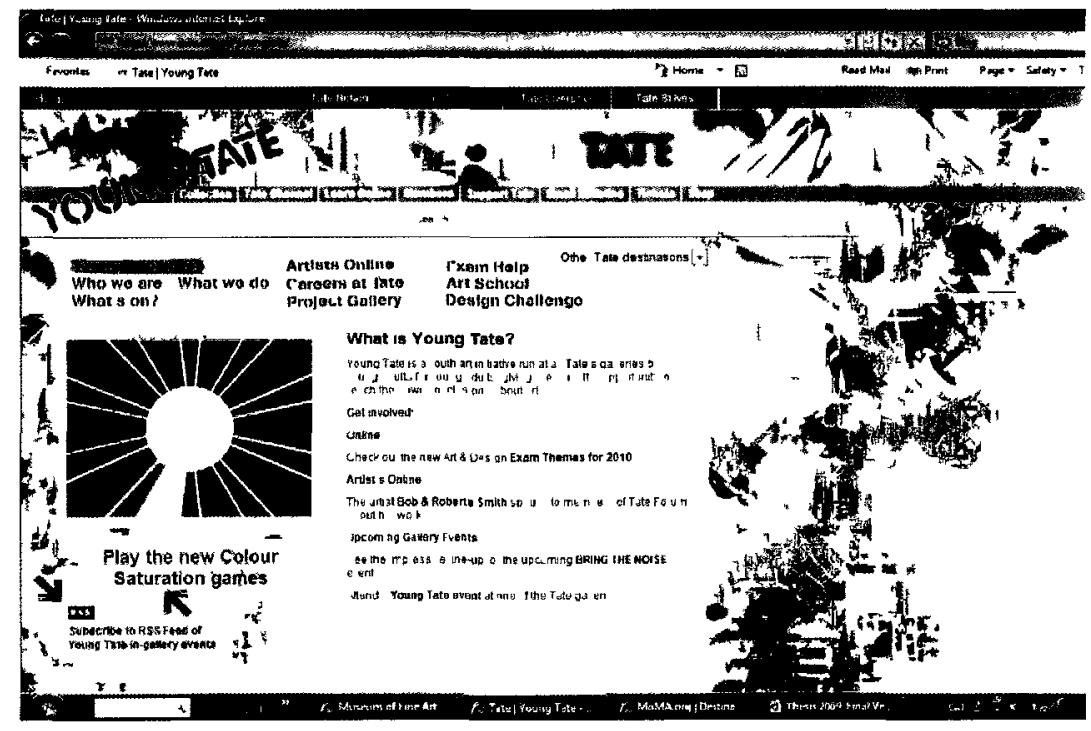


Having a website dedicated specifically to young people sends them the important message that, as a cohort, ${ }^{108}$ they are a vital part of the art museum family. And, while all four museums have programs for teens, Tate is the only one that has a dynamic (i.e. interactive) website especially for that group. This tells me that this museum, in particular, is seriously trying to reach out to more diverse (in this case, younger) audiences. Annex $\mathrm{C}$ provides more examples (screen shots) of how YoungTate reaches out to teens through its website.

\section{Images of People in Art Museums}

This section of the chapter discusses the images of people shown on the websites of each of the four case-study museums. Its purpose is to determine whether or not the pictures depict diversity and to determine which art museum publics might be able to recognise themselves in these images. My analysis is based partly on Roland Barthes' work in semiology_especially that area of his work that deals with the interpretation of images. In his book, Mythologies, for example, he argues that images are a lot more than just pretty pictures. Images, he says, always have a sub-text, a second meaning-a "what-goes-withoutsaying"109 (Barthes, 2001, p. 11). While Barthes used his theories to examine the "ideological abuse" of false consciousness (which he calls "myth") hidden in mass culture, I his these theories to suggest there are positive messages in these pictures from the museum websites. That is, I use them to suggest that if

\footnotetext{
${ }^{108}$ This is not to imply that we can put all teens together in one group, but merely to recognize that they do constitute a public for the art museum.

${ }^{109}$ Italics in the original
} 
people can see "themselves" reflected in these images, they will feel more empowered to visit the museums and participate in their activities.

Beginning with the National Gallery of Canada, I have found good representation of Canadian publics portrayed in its web images: likewise with the MFA, the MoMA and Tate Modern. The pictures below attest to this.

\section{NGC Images}

The NGC Website shows people from various walks of life participating in and enjoying the Gallery. We see large groups of children with a lecturer, small groups of children with a single adult, groups of adults with a lecturer and individual adults, all engaged in their art museum experiences.
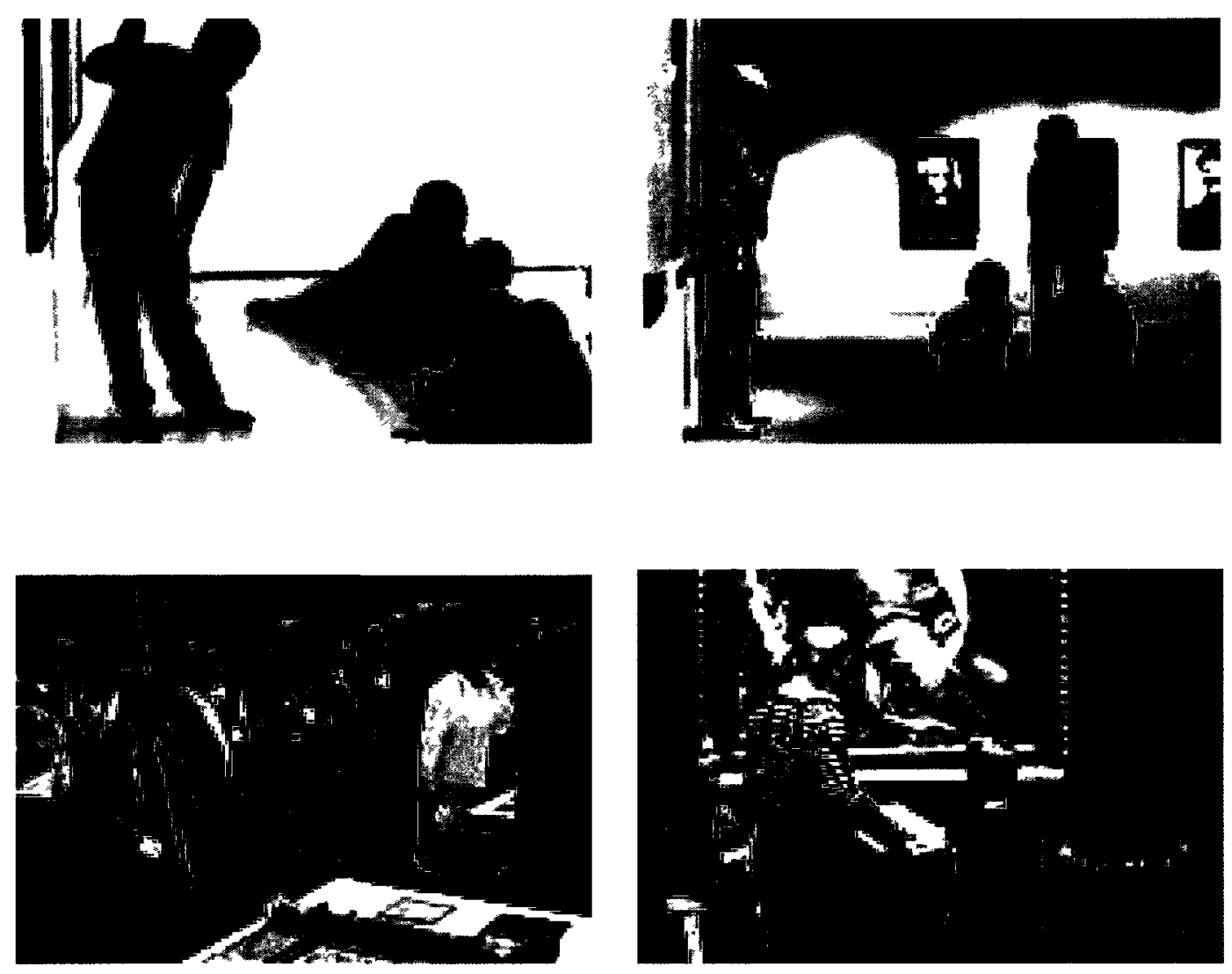

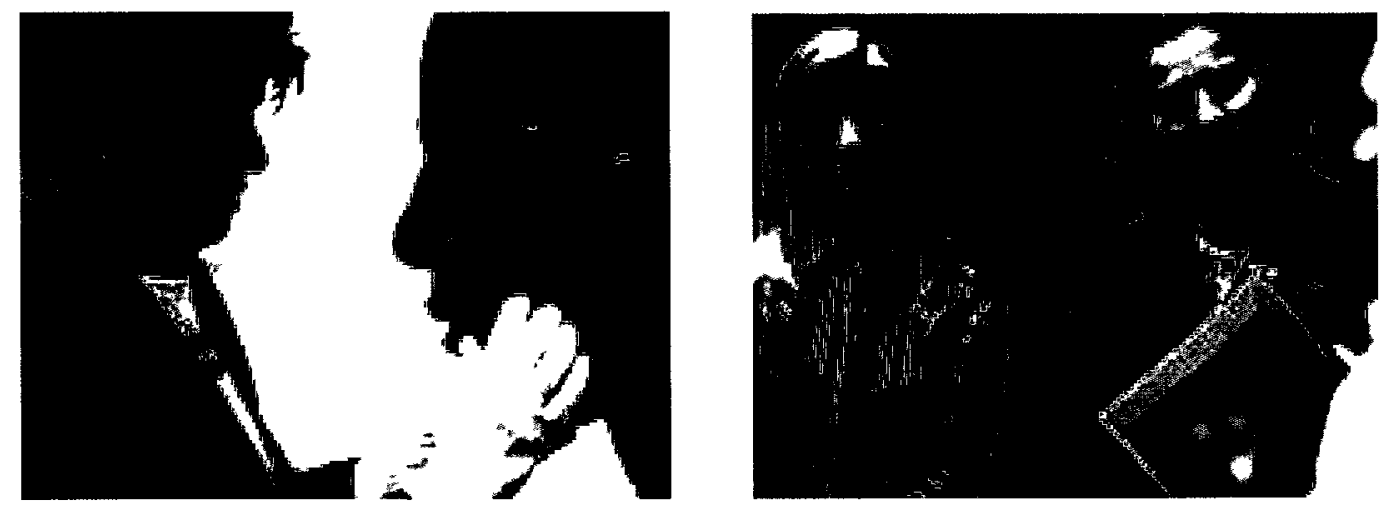

(All pictures from the NGC Website)

\section{MFA Images}

Like the NGC pictures, these images show children and adults from all walks of life enjoying various experiences at the MFA.
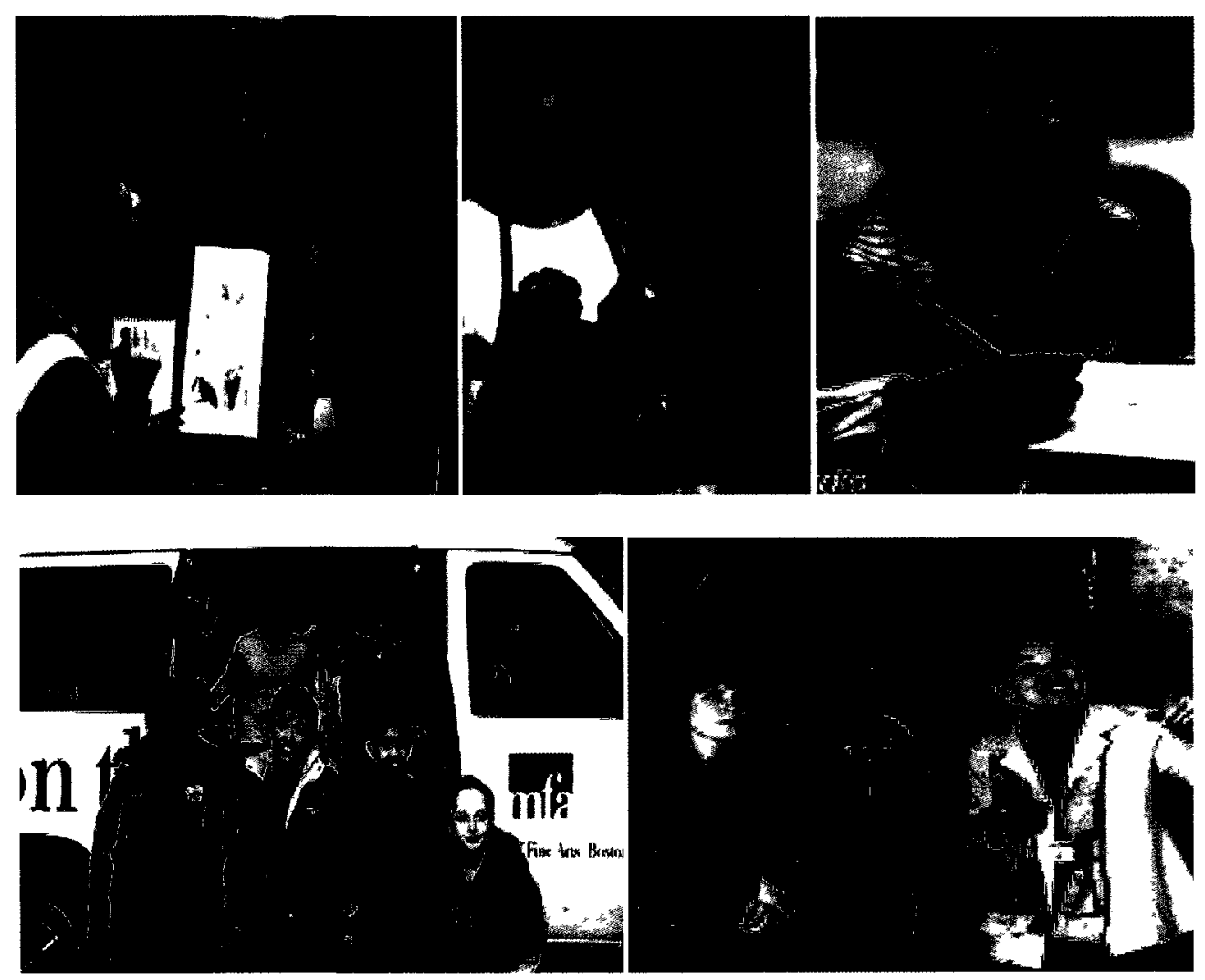


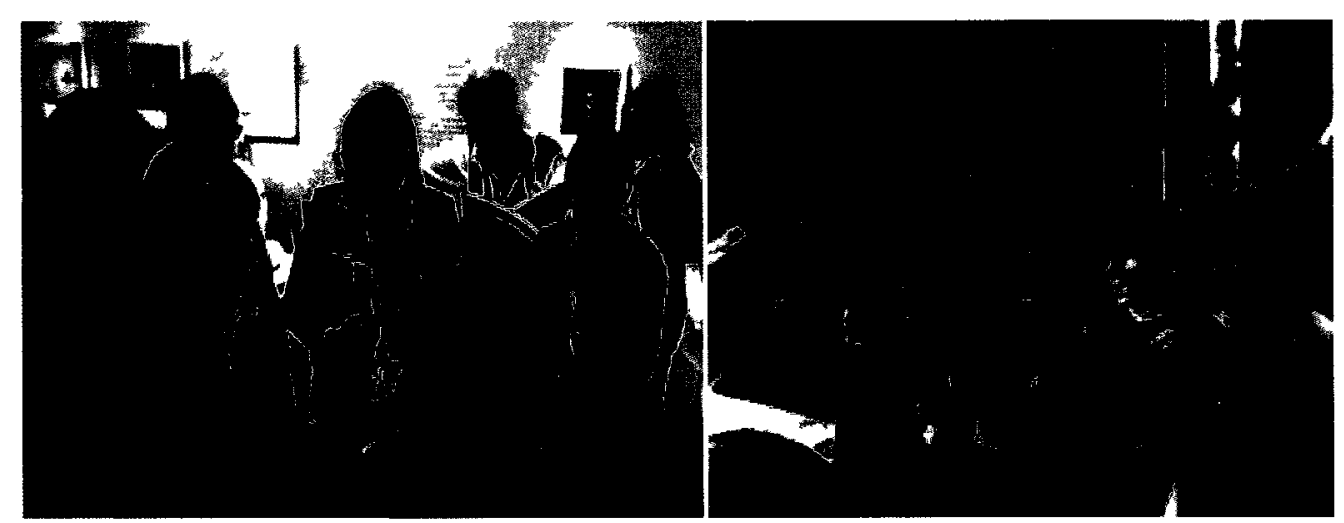

(Pictures from the MFA Website)

\section{MoMA Images}

Images from the MoMA Website depict visitors from a wide social milieu.
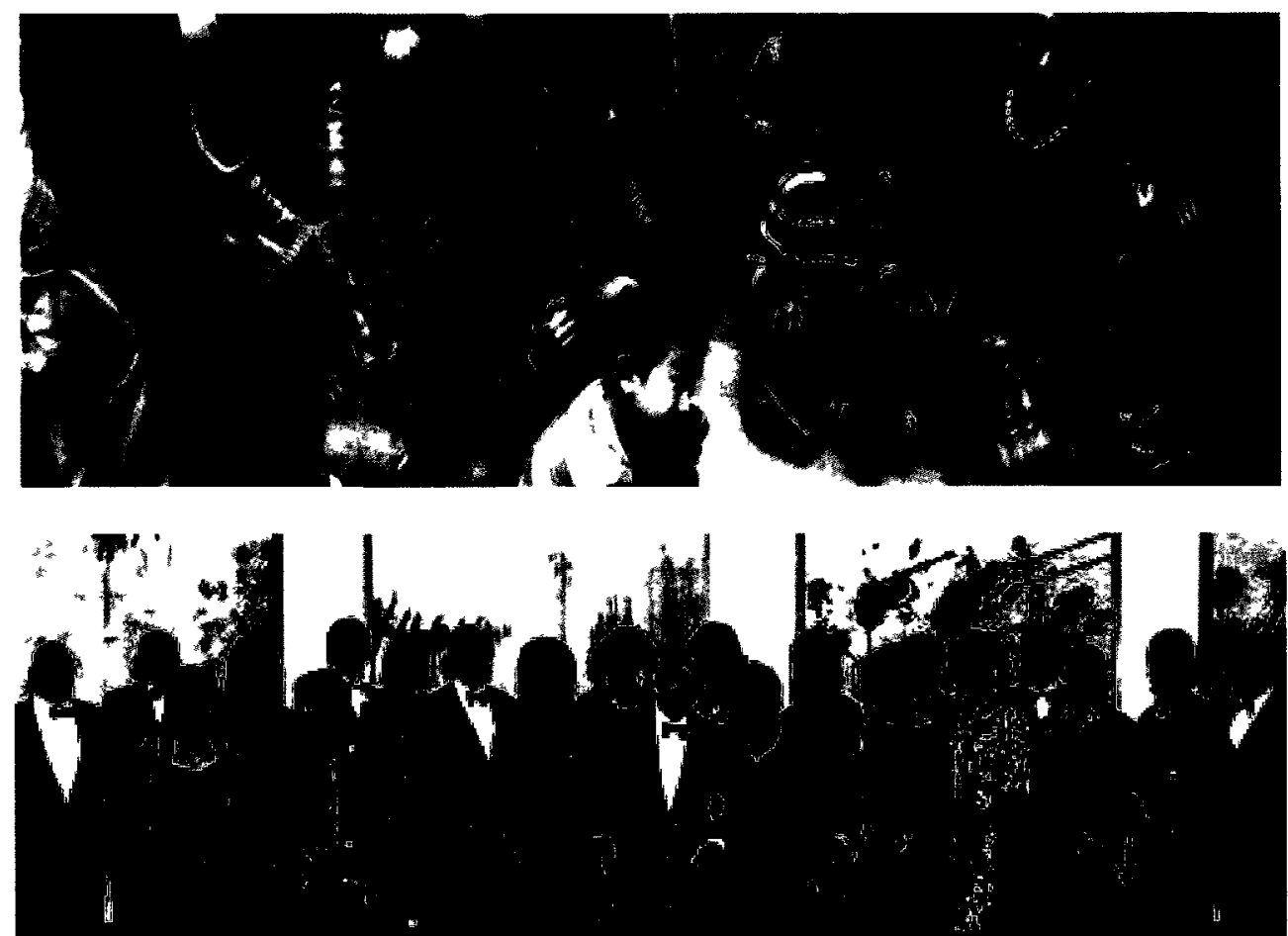

(Pictures from the MoMA Website) 


\section{Tate Modern Images}

Tate Modern images show children, teens and adults all enjoying the art museum experience. They all appear relaxed and engaged.
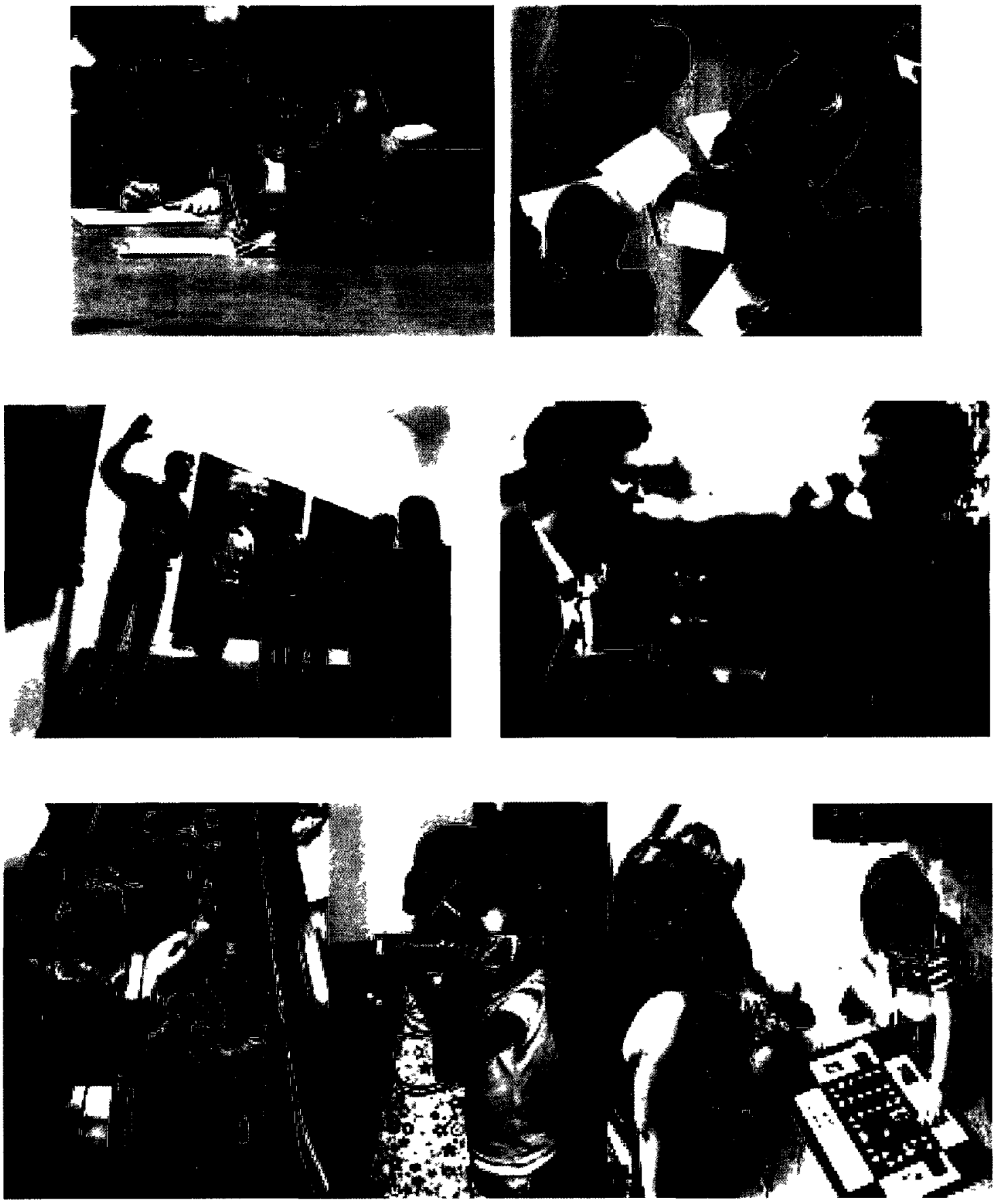

(Pictures from the Tate Modern Website) 


\section{Conclusion}

In this chapter I have analysed the websites of the four case-study museums selected. I have looked for answers to two main questions: 1) Do museum websites continue to perpetuate the same elitist discourses that other aspects of the museum do?, and 2) Can museum websites help to open up the art museum experience to wider audiences? That is, can websites attract people who would not usually enter the art museum complex?

While there are traces of elitism to be found on all of these websites, 1 have found that, for the most part, they offer an unprecedented amount of information for a large number of publics through their multimodal approach to communication (written language, images, film, video, sound, interactive activities, etc.). I have argued that this composite approach speaks to inclusion because it does not rely solely on written language to share information. ${ }^{110}$ । have suggested (after Hallett and Kaplan-Weinger, 2010) that individuals using these websites could construct identities for themselves that allow them to more fully participate in the art museum experience. In other words, I have said that art museum websites can be a source of cultural capital for many citizens who have never had the opportunity to develop it in more traditional ways. Museum websites, I believe, can help to alleviate some of the barriers found in other aspects of the art museum experience.

\footnotetext{
${ }^{110}$ This is not to deny that these websites are heavily slanted towards written language, but the fact that they use other communication tools makes them more accessible than art museum publications, for example.
} 


\section{Chapter Six: Conclusion}

"As long as museums do not ossify, they will have to transform themselves. Every generation will offer them new tasks and demand new achievements from them."

(Alfred Lichtwark, Director of Hamburg's Kunsthalle, (1903) (Cited by Gay 2008))

\section{Some Findings: A Review}

Much has been written about art museums as shrines, as temples, as "social and symbolic spaces" or as ideological [state] apparatuses. Even more has been written about the need for changes within the art museum complex: the need for art museums to become more inclusive, more democratic. Some have warned against too much change, fearing that turning the art museum into a space for popular entertainment would ultimately result in a loss of scholarship, of heritage and of excellence. Others have argued that the art museum, along with other cultural institutions, could be a place of social renewal, a place that could help heal the wounds of social exclusion. Most of this work on art museums has taken place within the disciplines of museum studies, cultural studies, sociology or art history.

My thesis has taken a different approach. I have been concerned with not only the changing roles of public art museums over the last 40 years, but also with the "how" of those changes within the discipline of communication studies. Using four major institutions (the National Gallery of Canada, the Boston Museum of Fine Arts, the Museum of Modern Art in New York and Tate Modern in London) as case studies, I have examined art museums as "means of communication," dissecting the ways in which they speak to their various publics 
from a number of different perspectives. That is, I have examined four art museums as "texts" and "laid bare the devise" (Wollen, 2003, p. 160). At the start of my dissertation, I said that one purpose of my research was to determine if, despite many changes over the last 40 years, we could say that, in general, art museums still construct hidden barriers that keep many potential publics away. To test this thesis, I have analysed both the overt and covert messages of four distinctly different art museums, all of which claim, in their mission statements or mandates, to reach out to many different publics. I have looked at how they communicate with their members, donors and other benefactors to enlist their continued support, not only by studying their direct marketing strategies (i.e. verbal messaging) but also by examining some of the hidden signifiers that work so powerfully "behind the scenes": for example, special benefits, elite gatherings, private viewings and public recognition. I have looked at the ways in which these same museums address their middle- and upper-middle class, well-educated clientele (stylish magazines and journals, erudite film and music programs, upscale restaurants and expensive designer items for sale in their shops) and I have examined the ways in which they communicate with their "publics at large."111 I have argued that from the very museum buildings themselves, to their interior ambiance, to the kinds of exhibitions they host, to the individual ways in which they "hang" their art, to their restaurants, cafés, bars and shops, to their member/donor benefits and to the design and content of their publications and their websites, as "means of communication" each of these museums, to a

${ }^{111}$ That said, I do not mean to imply that these are mutually exclusive. 
greater or lesser extent, continues to retain exclusive practices that may make some of their potential visitors feel unwelcome.

Using works by Bennett, Duncan, Preziosi, Marstine, Cameron and others to form a conceptual framework and set the scene for my research, I have shown how early museums were conceived as repositories of manners, as holy places and as places to confirm and reconfirm bourgeois identities. In particular, I have used Bennett (1995) to shows how social distinctions were built into art museums from the very beginning, and I have used Duncan (1995) to explain how art museums were and are places where social elites can validate their elitism and take that elitism back out into the society at large. To delve a little more deeply into how individuals can be moulded by social and cultural hegemonies, I use Preziosi's concept of the modern subject (2003). Preziosi believes that individuals construct subjectivies for themselves—especially when looking at art. The aesthetic experience, he says, is central to the production and preservation of modern identity, for both the individual and the society. The "construction of identity," he adds, is "linked to the orchestration and composition of a world in which we endeavour to find our place ..." (Preziosi, 2003, p. 20). All of these concepts are consistent with my thinking about how art museums both construct subjectivities and allow individuals to construct their own subjectivities in very unique ways. I have suggested, for example, that art museums attract those who would enhance their self-image(s) and the image(s) they present to the world through their association with such institutions-whether as wealthy sophisticates or as bohemian intellectuals, to name but two possible subject positions. Of 
course, motives for visiting and supporting art museums are many and will often be a combination of different reasons.

Another part of my research has been concerned with publications-with magazines, journals, brochures and catalogues, and with public lectures, films and music. I have argued that many of the publications produced by and for art museums are exclusive in the information they provide, the images they use, the advertising they carry and the breadth and depth of knowledge required to enjoy them. The way language is used is difficult for some readers to understand in many of these publications, which points to a select readership. And while brochures are less complex and more accessible, exhibition catalogues are often opulent and expensive-too expensive, I argue, for the average citizen.

Furthermore, I have found that lectures, films and music offered at the four case-study art museums selected often target individuals with high levels of education and cultural capital. I have suggested that this could, perhaps, be strategic: that offering elite publications and exclusive museum activities that subtly exclude large numbers of people (by making the cultural capital required to enjoy them well beyond their reach) is one way that art museums can continue to attract their elite members, donors and benefactors-even as they open their doors to wider audiences. At the same time, I have said that this is not a oneway process. Just as the art museum needs its elite patrons to provide financial support, elite patrons need the art museum to help construct and reconstruct their eliteness. 
Yet another part of my research has looked at museum buildings, internal ambiance, restaurants, bars, cafés and shops. I have used concepts from Umberto Eco (the semiotics of architecture) and Roland Barthes (the significance of signs) to determine what messages these features of my four museums send to their actual or potential visitors. I have argued, with Eco, that buildings themselves communicate-through both their external architecture and their internal ambiance. I have suggested, with Barthes, that hidden signs-the entrances, the viewing rooms, the restaurants, bars, cafés and shops, to name a few-help to create and perpetuate certain ideologies or myths that support the concept of the art museum as an elite institution. I have suggested, for example, that while the Museum of Modern Art and Tate Modern have public-friendly buildings, ${ }^{112}$ the Boston Museum of Fine Arts and, to a certain extent, the National Gallery of Canada, present a more formal face to the world. I have argued that the straight-off-the-street entrance to the Museum of Modern Art and the similar straight-off-the-Embankment entrance to Tate Modern make them more accessible to the casual visitor than the "destination" locations of the Boston Museum of Fine Arts and the National Gallery of Canada-that while the MoMA and Tate Modern answer, to a large extent, John Cotton Dana's plea for art museums that are located where they can be reached by the "maximum number of persons with a minimum of expenditure in time and money," (In Anderson, 2004, p. 21) the MFA and the NGC fall into Duncan's category of art museums that are set apart from the day-to-day. I have discovered that the

\footnotetext{
${ }^{112}$ For Tate Modern, this claim is supported by comments from Nicolas Serota, Michael Craig Martin and Sandy Nairne (2010) - discussed in Chapter Five.
} 
internal ambiance of both the MoMA and Tate Modern is generally more welcoming and more animated than that of either of the other two museumsand it is interesting to note that, despite Bourdieu's claims that only middle- and upper-middle class people like modern or contemporary art, it is the MoMA and Tate Modern that seem to attract the largest and most diverse audiences. ${ }^{113}$ Thus, I have argued that the MoMA and Tate Modern could be seen as Kristevian, semiotic texts "where multiple discourses occur, where multiple publics are embraced and where multiple approaches are initiated", while the NGC and the MFA remain Lacanian symbolic, name-of-the-father, transcendental signified texts (Pop Life and the new NGC director notwithstanding)—-keeping in mind, of course, that New York and London are much larger and more dynamic cities than either Boston or Ottawa.

At the same time, I have said that despite the open and welcoming ambiance of the buildings and the viewing rooms at the MoMA and Tate Modern, their restaurants and bars are more sophisticated, more expensive and more exotic than the restaurants at the NGC and the MFA. I have also said that all of these institutions offer less sophisticated cafés or vending machines for those who cannot or will not go to the more exclusive establishments--thus creating hierarchies of eaters as well as hierarchies of viewers. And, I have noticed that the exclusive restaurants are always in the best locations-once more creating

\footnotetext{
${ }^{113}$ Tate's Annual Report 2009-2010 indicates that visitor numbers over the last ten years had averaged between 4 and 5 million per year, with at least $30 \%$ of them coming from abroad. That same annual report also claims that Tate Modern has become the most popular modern art museum in the world. The Wall Street Journal reported in June 2010 that MoMA's visitor participation had reached 3.09 million that year (Orden, 29 June 2010). I have also observed a greater diversity of audiences in these two museums.
} 
barriers that could seem exclusionary to many potential publics. In addition, I have suggested that many of the goods found in art museum shops are expensive and exotic (designer), taking them out of reach of the average shopper and perhaps constituting another hidden barrier (Bourdieu, 2002).

Although much of my research points to the continuing eliteness of the four case-study museums, however, there are two areas where great strides in inclusiveness have been made. The first is in educational and outreach programs (including those for children and families) and the second is in the use of online tools (websites). All four museums go to great lengths to attract and interest young children and teens. Their educational programs for school groups and teachers are wide-ranging. They also offer more extensive family activities and community outreach programs than were available 40 years ago-although the degree to which intended audiences participate in these activities, and the long-term outcomes of such participation, might be a topic for further research. While I can say from participant observation that a great many school groups can be seen in the viewing rooms of all four of these museums, I do not know how many individual children participate in the family programs-but at least some of the research I have used (Lemerise and Soucy, 1999) indicates that it is mostly the children and teens of well-educated parents (those who have large amounts of cultural capital) that frequent museums, especially art museums. Still, these are messages that speak inclusion-that on the surface, at least, as "means of communication," seem to welcome families from all walks of life, no matter what their cultural background or education level. 
Finally, I have found that art museum websites not only offer unprecedented access to information of all kinds, but also provide outstanding tools for developing or increasing cultural capital. Looking again to Bourdieu (2002), DiMaggio (1987), Gans (1999), Lamont and Lareau (1992) as well as to Boltanski and Thévenot (1999) and Rosenberg (1995), I suggest that these websites might help to expand or build upon, the habitus; that they might, as an alternative "means of communication," help to provide the education that individuals need to become actively involved in the art-museum world. I have argued, for example, that the "visits" page on all four of my case-study museums, by providing reluctant individuals with the opportunity to become familiar with layouts and museum visit protocols (for example) ahead of time, may give them the added confidence they need to visit. I have said that, if we accept the theories of Boltanski and Thévenot (1999) that people are judged by "plural orders of worth"-that, a person's worth is constantly determined and redetermined by how he or she reacts in different situations-we might be able to argue that having a strong understanding of "where to go" and "what to do" could help an individual feel more at home in the art museum environment. Helping people overcome their reluctance to visit art museums is one way in which museum professionals could begin to break down the barriers that keep some potential publics away. I have also argued that other aspects of these websites-with so much information about the art, the artists, the exhibitions, etc.-presented not just as written texts but through multiple communication methods, could also increase people's feelings of worth according to Boltanski 
and Thévenot's model (1999), or help them determine a keener sense of agency through what Rosenberg (1995) calls "individually determined action" These are just some of the ways that an individual could increase his or her cultural capital through using museum websites. I believe that the role of art museum websites in the inclusion/exclusion debate is a topic that lends itself to much further research.

\section{Reflections}

The question remains, why should we care? Is it not enough to say that those who want to go to art museums will go, and those who do not feel comfortable in them will stay away, and leave it at that? Perhaps, but this brings me back to the Liverpool taxi drivers who thoroughly enjoyed their visits to Tate Liverpool once someone took the trouble to take them there-most of the taxi drivers who participated in the project, in fact, were able to understand, appreciate and enjoy the art-once they were given a chance. This supports the idea that there is nothing inherent about the working classes not understanding art or feeling uncomfortable in the art-museum world.

That is not to say that I share the (former) British Government's belief that art and art museums can help to solve the social ills of the country. On the other hand, I cannot agree with Claude Debussy, who said that "art is of absolutely no use for the masses" (Debussy, 1927, cited in Gay, 2008, p.70). That said, neither can I fully agree with German aesthetician, Wilhelm Worringer, who believed that the "the only value of the work of art ... lies, generally speaking, in 
its power to bestow happiness"114 (Worringer, 1908, p. 13, cited in Gay 2008, p. 131). Nor can I support the Russian Modernist, Kizamir Malevich, who argued that "art is the new religion" (Malevich, 1927, cited in Gay, 2008, p. 136).

Where, then, do I stand? I must admit to falling somewhere in between these extremes. I do believe that art can be enriching. That is, I believe that art of all kinds (painting, literature, music, theatre, film, the plastic arts, etc.) is important to help us develop more completely as well-rounded, creative individuals or, to paraphrase Deitch, that art can help to change an individual's consciousness. I also believe, with Mouffe, that art and cultural institutions like art museums have a role to play in challenging political hegemonies and helping to shape political landscapes. Nussbaum's argument that "cuts in humanities teaching pose a threat to democracy" is also a powerful one (Nussbaum, TLS, 30 April, 2010, p.13). Nussbaum sees the demise in humanities teachingexposure to art, literature, music, etc.,- -at all levels of the education system and beyond as the direct result of our pursuit of profit in the global marketplace. She warns that we will never solve our widespread economic, environmental and social problems with factual knowledge alone. "Science, social science and economics," she argues, can only be practiced at their best when "infused" with what she calls "the spirit of the humanities: by searching critical thought, daring imagination, empathetic understanding of human experiences of many different kinds, and understanding of the complexity of the world we live in-a world in which people face one another across gulfs of geography, language and

\footnotetext{
${ }^{114}$ A similar comment was made by Sir Kenneth Clarke former director of the National Gallery in London (Clarke 1954, p. 29 - cited in Marstine, Ed., 2006).
} 
nationality" (ibid.). Nussbaum draws on Socrates as well as Tagore, Thucydides, Rousseau, Dewey and British paediatrician/ psychoanalyst D.W. Winnicott (among others) to make her point. All of these thinkers considered participation in the arts as central to human development.

My argument, then, as stated at the beginning of this thesis, is that exposure to art is important for the continuation of civil society. If it is true that we are giving up much of our humanities teaching in our schools and universities and cutting back on our funding of the arts in general-and there is much evidence to support this ${ }^{115}$-then we must rely on our cultural institutions, in this case art museums, to ensure most diligently that as many people as possible, from the youngest child to the oldest citizen from every walk of life, get exposure to great works. My benchmark for making art accessible stems from two exhibitions I attended while living in Germany in the early 1980s: the first, a Chagall exhibition held in a supermarket in Freiburg; the second, also Chagall but not the same exhibition, held in the Rathaus (City Hall) in Hamlin. Extraordinary as these exhibitions might seem, they sent a clear message to a myriad of German publics that art (like music and theatre which are often played and performed in the Stadtparks—-the City Parks), is for everybody. The message was received in kind. And, while I'm not suggesting that we have our

${ }^{115}$ In the US, the recently released Spelling Report emphasizes the need for colleges and universities to focus on science, technology and economics (Spelling, 2006). In Britain, Lord Mandelson, the Business secretary, who is responsible for higher-education funding, has ordered budget cuts of $£ 600 \mathrm{~m}$ by 2013 and called for stronger ties between universities and business (Asthana and Williams, The Observer, Sunday 28 February 2010). In Canada, the Harper Government is known for its ongoing cuts to the arts with especially deep cuts occurring in 2008-although as of April 2010, \$15M have been set aside by the Federal Government for four national museums within the National Capital Region, including $\$ 2 \mathrm{M}$ for the National Gallery of Canada " (Raj, Toronto Sun, April, 15, 2010).. 
art museum directors and curators transport their Picassos, Van Goghs, Gauguins, Rothkos, etc., down to the Metro, Tesco or Wal-Mart, I am suggesting that we need to find more innovative ways to make art as accessible as possible. That means making our public art museums reach out to, and speak to, new and more diverse audiences. Not only that, but we must find innovative ways to bring art to audiences outside of the museum complex-to let all our publics know and feel that art is for them.

My stated purpose at the beginning of this thesis was two-fold. First to determine if public art museums, despite many changes over the past 40 years, still retain an air of elitism left over from earlier days regardless of their claims to have become more inclusive; and second to evaluate some of the ways in which they are reaching out to more diverse publics. I believe my research has shown that these public art museums have, since the mid- $20^{\text {th }}$ century, made many changes towards becoming more inclusive. Nonetheless, as "means of communication," they have all, to a greater or lesser degree, retained traces of elitism, creating hidden barriers that keep some of their potential publics away. That said I believe that their outreach and education programs, especially, will bring more and more people into the museum complex. Audio guides and didactic panels are helping enormously in providing information for visitors who might otherwise stay away. However, it is their websites, I believe, that offer the greatest opportunity for change. That is, I feel that through their websites, museum professionals can help a great many more people not only gain 
knowledge about art and artists but also develop the cultural capital they need to participate more fully in the art museum experience.

\section{Moving Forward}

Where then could this research lead? For me, an important question going forward will be to determine to what degree museum websites are bringing new publics into the art museum complex by increasing their cultural capital-as opposed to just providing them with cursory information-and to explore ways to further exploit this idea of websites as tools of inclusion vis-à-vis art museums. On the same theme of inclusion, a further look into the role of museum buildings as "means of communication" in the inclusion/exclusion equation could yield some thought-provoking data. This dissertation has not included the role of corporate sponsors in the art museum dialogue, but this too could make an excellent research topic. In addition, valuable results may be yielded by visitor surveys during temporary exhibitions, and population surveys that include demographic characteristics such as age, gender, ethnicity, education level and income, etc.

A follow-up on Glynn, Bhattacharya and Rao's research on art museum members and their reasons for joining (1995) or on Lemerise and Soucy's work with adolescents and [art] museums (1999) are other areas of interest. Finally, a history of museum visitor studies could make a stimulating and rewarding research topic (Bennett, 1999). 


\section{Bibliography}

Alexander, E. P. (1979). Museums in motion: An introduction to the history and functions of museums. Toronto and Oxford: Altamira Press.

Althusser, L. (1993). Essays on ideology. London, England: Verso.

Althusser, L. (1971). Lenin and philosophy and other essays. New York and London: Monthly Review Press.

Annual Report. (2007-2008). National Gallery of Canada and the Canadian Museum of Contemporary Photography, American Association of Museums Website. (2010). Retrieved May 2010 from http://www.aam-us.org.

Art Institute of Chicago Website (2010). Retrieved May 2010 from http://www.artic.edu/.

Barthes, R. (1968) Elements of semiology, New York: Hill and Wang.

Barthes, R. (1994). The semiotic challenge. Berkeley and Los Angeles: The University of California Press.

Barthes, R. (1997). Toward a psychosociology of contemporary food consumption. In Counihan, C. and van Esterik, P (Eds.). Food and culture: $A$ reader. New York: Routledge.

Barthes, R. (2001). Mythologies. New York: Hill and Wang.

Baudrillard, J. (1997). The Beaubourg effect. In Leach, N. (Ed). Rethinking architecture: A reader in cultural theory. London and New York: Routledge. 
Benjamin, W. (2002). The arcades project. (Howard Eiland and Trevor

McLaughlin Trans.). Cambridge, Massachusetts and London, England:

The Belknap Press of Harvard University Press.

Bennett, T. (2005). The birth of the museum. In Greenberg, R.,

Ferguson, B. and Nairne, S. (Eds.), Thinking about exhibitions. London \& New York: Routledge.

Bennett, T. (1995). The birth of the museum. London \& New York: Routledge.

Bignell, J. (1997), Media semiotics, an introduction. Manchester:

Manchester University Press.

Boltanski, L. and Thévenot, L. (1999). The sociology of critical capacity. European Journal of Social Theory. 2, 359-377. Retrieved July 2009 from Doi:10.1177/136843199002003010.

Bourdieu, P. (2002). Distinction: A social critique of the judgement of taste. (R. Nice, Trans.). Cambridge, Massachusetts: Harvard University Press. Bourdieu, P. (1993). The Field of Cultural Production: Essays on art and literature. In Johnson R. (Ed.), New York: Columbia University Press. Bourdieu, P, Darbel, A \& Schnapper, D. (2004). The love of art. In Museum Studies: An Anthology of Contexts. Carbonell (Ed.), Maldon, MA, Oxford, UK and Victoria, Australia: Blackwell Publishing Ltd.

Brown, E. (1913). The ANNALS of the American Academy of Political and Social Science, 45, 171-176. Retrieved January 2008 from doi: $10.1177 / 000271621304500112$. 
Burchell, G., Gordon, C. and Miller, P. (Eds.). (1991). Questions of method - The Foucault effect: Studies in governmentality. Chicago: University of Chicago Press.

Burt, Nathanial. (1977). Palaces for the people: A Social history of the American art museum. Boston: Little, Brown.

Cameron, Duncan F. (2004). The museum, a temple or the forum. In Anderson, G. (Ed.). Reinventing the museum: Historical and contemporary perspectives on the paradigm shift. London, New York, Toronto, Oxford: Altamira Press.

Carbaugh, D. (1996). Situating selves: The communication of social identities in American scenes. New York: SUNY.

Churchill, W. (1943) Meeting in the House of Lords, 28 October 1943, (http://www.winstonchurchill.org/learn/speeches/quotations.

Clarke, K. (2006). In Marstine (Ed.). New museum theory and practice: An introduction. Maldon, MA, Oxford, Victoria AU: Blackwell Publishing. Cook, M. (May 11, 2000). Ottawa Citizen.

Cottom, D. (Summer 1981). Taste and the civilized imagination. The Journal of Aesthetics and Art Criticism, 39, 4, 367-380. Retrieved April 2010 from ttp://www.jstor.org/stable/430236.

Crooke, E. (2007). Museums and community: Ideas, issues and challenges. New York and Abingdon, Oxon: Routledge.

Culture Kiosk. (http://www.culturekiosque.com/art/exhibiti/matissepicasso.html). 
Dana, J. C. (2004). The gloom of the museum. In Anderson, G. (Ed.).

Reinventing the museum: Historical and contemporary perspectives on the paradigm shift. London, New York, Toronto, Oxford: Altamira Press.

DiMaggio, P. (1987). Classification in art. American Sociological Review,

52, 4, 440-455. Retrieved April 2010 from

http://www.jstor.org/stable/2095290.

DiMaggio, P. (1979). On Pierre Bourdieu. The American Journal of Sociology.

1. 84. 6. 1460-1474. Retrieved from http://www.jstor.org/stable/2777906.

DiMaggio, P. and Useem, M. (1980) The arts in education and cultural participation: The role of aesthetic education and the arts. Journal of Aesthetic Education, 1. 4. 55-72. Retrieved April 2008 from http://www.jstor.org/stable/3332369, June 2009.

Djonov, E. (2004). Website hierarchy and the interaction between content organization, webpage and navigation design. Information Design Journal 15(2), 143-162. Amsterdam: John Benjamins Publishing Company.

Duncan, C. (1995). Civilizing rituals. London and New York: Routledge. Eco, U. (1997). Function and sign: The semiotics of architecture. In Leach, N. (Ed) Rethinking architecture: A reader in cultural theory. London and New York: Routledge.

Enwezor, O. (2009). Discussion on Hardt and Negri, Artforum. October. Retrieved January 2011 from http://www.artforum.com.

Fairclough, N. (2009). Discourse analysis: Textual analysis for social research. London and New York: Routledge. 
Fairclough, N. (2005). Critical discourse analysis, organisational discourse, and organisational change. Organization Studies, 26 (6). pp. 915-939. Retrieved January 2011 from ISSN Online ISSN: 1741-3044 Ferguson, B. (1996). Exhibition Rhetorics: Material Speech and Utter Sense. In Greenberg, R. Ferguson, B. and Nairne, S. (Eds.). (1996). Thinking about exhibitions. London \& New York: Routledge.

Financial Times Weekend. (2010, May 1, 2). Life \& Arts. pp.10-11.

Financial Times Weekend. (2009, January 24, 25). Life \& Arts., p. 11.

Foucault, M. (2000). Power. James B. Faubion (Ed). New York: The New Press.

Foucault, M. (1988). Politics, philosophy, culture: Interviews and other writings. New York and London: Routledge.

Foucault, M. (Summer, 1982). The subject of power. Critical Inquiry, 8.

Foucault, M. (1980). Power/knowledge: Selected interviews and other writings. New York: Pantheon Books.

Foucault, M. (1977). Discipline and punish: The birth of the prison. New York: Pantheon Books.

Freidland, L., Shah, D.V., Lee, N.J., Rademacher, M.A., Atkinson, L., and Hove. (2007). Capital consumption, communication and citizenship: The social positioning of taste and civic culture in the United States. ANNALS, AAPSS, 611, 1, 31-50. Frieze Magazine. (n.d.). Retrieved from http://www.frieze.com.

Glynn, M-A., Bhattacharya, C.B. and Rao, H. (1995). Art 
Museum membership and cultural distinction: Relating members' perceptions of prestige to benefit usage Poetics 24, 259-274. Doi:10.1016/j.physletb.2003.10.071.

Glynn, M-A., Bhattacharya, C.B., and Rao, H. (1995a) Understanding the bond of identification: An investigation of its correlates among art museum members. Journal of Marketing, 59. 4 October: $46-57$. Retrieved June 2008 from http://www.ESMT.org.

Gans, H. J. (1999). Popular culture and high culture: An analysis and evaluation of taste. New York: Basic Books, Inc.

Gay, P. (2008). Modernism: The lure of heresy from Baudelaire to Beckett and beyond. December 1. London: W.W. Norton Company Ltd. Gibson, I. (2008). Arts and wellbeing foundation degree (ppt. presentation), City College Norwich. Retrieved January 2011 from http://www.ccn.ac.uk. Greenberg, R., Ferguson, B., and Nairne, S. (Eds.). (1996). Thinking about exhibitions. London \& New York: Routledge.

Greenberg, C. (1983). Taste. Transcript of a talk given by Clement Greenberg at Western Michigan University. Retrieved March 2010 from http://www.sharecom.ca/green berg/taste.html.

Grossberg, L. (1886). On postmodernism and articulation: An interview with Stuart Hall. Journal of Communication Inquiry, 10, 45. Group for large local authority museums. (2000). Museums and social inclusion: The GLLAM Report. Leicester: University of Leicester Press. 
Gunter, B. (2000). Media research methods. Thousand Oaks, California: Sage Publications Ltd.

Habermas, Jurgen. (1991). The structural transformation of the public sphere: An inquiry into a category of bourgeois society. (Burger, T. and Lawrence, F. Trans.). Boston: MIT Press.

Hannam, K. and Knox, D. (2005). Discourse analysis in tourism research: A critique. Tourism Recreational Research 30 (2) 23-30.

Hallet, R. W. and Kaplan-Weinger, J. (2010). Official tourism websites: A discourse analysis perspective. Bristol, Buffalo, Toronto: Chanel View Publications.

Haskell, F. (2000). The ephemeral museum: Old master paintings and the rise of the art exhibition. New Haven, CT: Yale University Press.

Herzog \& de Meuron. (2000). Tate Modern (DVD). Beat Kurt, Director. CH6864 Arzo: Al Castello.

Hewitt, A. (2011). Privatizing the public: Three rhetorics of art's public good in 'third way' cultural policy. Art \& the Public Sphere, I: I, pp.19-36, doi:10.1386/aps.1.1.19-1.

Internet world stats. (http.www.internetworldststs.com/stats.htm).

Jameson, F. (1997). The cultural logic of late capitalism. In Leach, N.

(Ed). Rethinking architecture: A reader in cultural theory. London and New York: Routledge.

Jenkins, R. (2002). Pierre Bourdieu revised edition: Key sociologists series. London: Routledge. 
Kim, S. T. and .Weaver, D. (2002,December) New Media \& Society, vol., 4: pp. 518-538.

Klein, R. N. (2008) Art museums, patronage, and the transformation of culture in the nineteenth century, Journal of Urban History, 34, 2, 345-360 Retrieved from doi:10.1177/0096144207308684. March 2010.

Kress, G. \& Van Leeuven, T. (2001). Multimodal discourse: The modes and media of contemporary communication. London: Oxford University Press.

Kress, G. \& Van Leeuven, T. (1996). Reading images: The grammar of visual design. London and New York: Routledge.

Kress, G. \& Van Leeuven, T. (2006). Bell, A. \& Garrett, P. (Eds) (1997) Approaches to media discourse. Oxford: Blackwell Publishers Kristeva, J. (1980). Desire in language: A semiotic approach to literature and art. Roudiez, L. S. (Ed.). T. Gora, A., Jardine and L. S. Roudiez (Trans.). New York: Columbia University Press. Lacan, J. (1977). Écrits: A selection. New York: W.W. Norton \& Company. Lamont, M and Lareau, A. (1988). Cultural capital: Allusions, gaps, glissandos in recent theoretical developments. Sociological Theory, 6 153-168. Retrieved June 2007 from http://www.jstor.org/stable/202113.

Lash, S. (2007). Power after hegemony: Cultural studies in mutation. Theory, Culture \& Society, 24, 3, 55-78.

Lash, S. (1990). Sociology of postmodernism. London: Routledge. Lemerise, T. and Soucy, B. (1999). Le point de vue d'adolescents 
montréalais sur les musées. Revue canadienne de l'éducation 24,4 , 355-368. Retrieved May 2010 from http://www.cssescee.ca/CJE/Articles/FullText/CJE24-4/CJE24-4-lemerise.pdf.

Library and Archives Canada Website, www.collection.gc.ca.

Lowry, G., D. (2005). The new Museum of Modern Art. New York: The Museum of Modern Art Press.

Matarasso, F. (2002). A Cultural Imperative? In QUEST, Social inclusion in action, final draft (London: Quality, Efficiency and Standards Team). Retrieved June 2010 from onlinelibrary.wiley.com/doi/10.1111/1467-8705.00457/pd.

McClellan, A. (2008). The art museum from Boulée to Bilbao. Berkeley, Los Angeles, London: The University of California Press.

McNeil, P. (2008). The web designer's idea book. Cincinnati, Ohio: HOW Marstine, J. (Ed). (2006). New museum theory and practice: An introduction. Maldon, MA, Oxford, Victoria AU: Blackwell Publishing.

Martin, M. C. (2000). Towards Tate Modern. In Blazwick, I. and Wilson, S. (Eds.). Tate Modern the handbook. Berkley and Los Angeles: University of California Press.

Martin, M. (2006). Images of war. Toronto: University of Toronto Press. Melton, M. (2009). Invitation to art: A history of the Museum of Fine Arts, Boston. Boston: MFA Publications.

Milner, Andrew. (1994). Cultural materialism, culturalism and post-culturalism: The legacy of Raymond Williams. Theory, Culture and Society, 11, 43. 
MoMA. (May/June, 2000). The Museum of Modern Art. Retrieved from http://www.jstor.org.proxy.library.carleton.ca/stable/i398558

MoMA. (June, 2001). The Museum of Modern Art. Retrieved from http://www.jstor.org.proxy.library.carleton.ca/stable/4420587

MoMA. (May, 2002). The Museum of Modern Art. Retrieved from http://www.jstor.org.proxy.library.carleton.ca/stable/i398687

Mumby, D. (1987). The political function of narrative in organizations. Retrieved April 2010 from http://www.coms.ohiou.edu/Websites/coms/Files/ Content/539313/mumby.pdf.

Newsom, B. and Silver, A. Z. (1978). The art museum as educator. University of California Press: Berkeley and Los Angeles.

Nielson, J. and .Tahir, M. (2002). Homepage usability. Carmel, Indiana: New Riders Publishing.

Nikkhah, R. (2010, 11 May). The Telegraph. Retrieved from www.telegraph.co.uk.

Nixon, M. (2001). Tate Round Table. In October, Fall 2001, No. 98, Pages 3-25 Posted Online March 13, 2006. Retrieved May 2010 from doi:10.1162/octo.2001. 98.1.3.

North, A. C. and Hargreaves, D. J. (2007). Lifestyle correlates of musical preference: 3 . travel, money, education, employment and health." Psychology of Music. 35, 473. Retrieved June 2009 from doi: $10.1177 / 0305735607072656$.

Nussbaum, Martha. (2010, 30 April). The Times Literary Supplement, p.13 
Ord, D. (2003). The National Gallery of Canada: Ideas, art, architecture. Montreal and Kingston: McGill-Queen's University Press.

Orden, E. (2010, 29 June). The Wall Street Journal. Retrieved from www.wsi.com.

Ouellette, L. (2002). Viewers like you: How public TV failed people. New York: Columbia University Press.

Policy Action Team. (2000) The national strategy for neighbourhood renewal. Policy Action Team Report Summaries: A Compendium, PAT 10.

Preview. (2010). The Boston Museum of Fine Arts. May/June.

Preview. (2010). The Boston Museum of Fine Arts. March/April.

Preview. (2010). The Boston Museum of Fine Arts. January/February.

Preziosi, D. (2003). Brain of the earth's body: Art museums and the phantasms of modernity. Minneapolis, London: University of Minnesota Press.

Prior, N. (2002). Museums \& modernity: Art galleries and the making of modern culture. Oxford: Berg. 2002.

Rabinow, P. (Ed.). (1984). The Foucault reader. New York: Pantheon Books.

Raj, A. (2010, April 18). The Toronto Sun, Retrieved April 2010 from http://www.torontosun.com.

Rosengren, K. E. (1995). Substantive theories and formal modals Bourdieu confronted. The European Journal of Communication, 10, 7. Retrieved June 2009 from doi: 10.1177/0267323192007003002.

Round Table: Tate Modern. (2001, Autumn), Nixon, M., Potts, A., Fer, B., Hudek, and Stallabrass, J. October, Vol. 98, pp. 3-25. Boston: The MIT Press. 
Posted Online March 13, 2006. Retrieved May 2010 from doi:10.1162/ octo.2001. 98.1.3.

Russell, J. (1998). Art review: Catherine, also great as a collector.

Retrieved June 2008 from http://www.nytimes.com/1998/10/01 /arts/artreview-catherine-also-great-as-a-collector.html.

Sandell, R. (Ed.). (2002). Museums, society, inequality. London and New York: Routledge.

Selwood, S. (2003). What difference do museums make? Producing evidence on the impact of museums. Critical Quarterly, 44, 4.

SEU (1998). Bringing Britain together: A national strategy for neighbourhood renewal (Cm 4045), TSO.

Shaughnessy, J. (2010, (Autumn, 2001),). CBC News. 22 September. CBC News.

Siegelaub. S. (1983). Communication and class struggle, Vol 1. New York: International General.

Siegelaub. S. (1983). Communication and class struggle, Vol 2. New York: International General.

Spigal, L. (2008). TV by design: Modern art and the rise of network television. Chicago: The University of Chicago Press.

Staniszewski, M. A., Buck-Morris, S., \& and Druckrey, T. (1998). The power of display: A history of exhibition installations at the museum of Modern Art. Boston: MIT Press.

Stempel, G. H., III, \& Stewart, R. K. (2000). The internet provides both 
opportunities and challenges for mass communication researchers. Journalism \& Mass Communication Quarterly, 77(3), 541-548.

Sturken, M. and Cartwright, L. (2009). Practices of looking: An introduction to visual culture. (2 ${ }^{\text {nd }}$ Edition). New York and Oxford: Oxford University Press.

Tate ETC. Issue 13. (Autumn 2007). Tate Media.

Tate ETC. Issue 16. (Summer 2008). Tate Media.

Tate ETC. Issue 16. (Summer 2009). Tate Media.

Turner, D. (1989). Safdie's gallery: An interview with Moshe Safdie. Ottawa: David Lewis (electronic publishing).

Tate Report. (2002-2004). Retrieved from http://www.tate.org.uk.

Tate Report. (2008-2009). Retrieved May 2010 from www.tate.org.uk.

The Art Institute of Chicago (2011). http://www.artic.edu/aic/exhibitions/ medici/themes.html.

The Boston Museum of Fine Arts. (2010) http://www.mfa.org.

The Boston Museum of Fine Arts Memberships. (2010). http:www.mfa.org/membership.

The Boston Museum of Fine Arts Shop. (2010). htpp://www.mfashop.com. The Canadian Museum Association Website. http://www.museums.ca. The Department of Culture, Media and Sports. (2011). www.culture.gov.uk. The Medici, Michelangelo and the Art of Late Renaissance Florence. (2003) Retrieved from http://www.artic.edu/aic/exhibitions/ medici/themes. html\#baroque. 
The Museum of Modern Art. (2010). http://www.moma.org.

The Museum of Modern Art Memberships. (2010).

http://www.moma.org/support/membership/programs.

The Museum of Modern Art Shop. (2010). http//www.momastore.org.

The National Gallery of Canada. (2010). http//www.gallery.ca.

The National Gallery of Canada Memberships. (2010).

https://www.shopngc.ca/membership/Membership/Main.do?lang=en.

The National Gallery of Canada Shop. (2010). http://www.shopgc.ca.

Thévenot, L. (2007). The plurality of cognitive formats and engagements:

Moving between the familiar and the public. European Journal of Social

Theory, 10, 409. Retrieved June 2009 from doi:10.1177/136843100 7080703.

Thoburn, N. (2007). Patterns of production: Cultural studies after hegemony: Cultural theory and its futures. Theory, Culture \& Society. 24, 3, 79-94.

Vernissage. (Winter 2007). The National Gallery of Canada.

Vernissage. (Fall 2008). The National Gallery of Canada.

Vernissage. (Winter 2008). The National Gallery of Canada.

Virtual Tourist (2008). http://www.virtualtourist.com.

Williams, R. (1998). Keywords. London: Fontana Press.

Williams, R. (1987). Culture and society. London: The Hogarth Press Ltd.

Williams, R. (1963). Communications. London: Chatto \& Windus. 
Wodak, R., de C., Reisigl, M and Liebhart, K. (1999). The discursive construction of national identity. Edinburg: Edinburg University Press.

Wollen, P. (2003). Knight's moves. In Camera obscura camera lucida: Essays in honor of Annette Michelson. Allen, R. and Turvey, M. (Eds). Amsterdam: University of Amsterdam Press. 


\section{Annex A - Survey Questionnaires}

\section{NGC Survey Questionnaire}

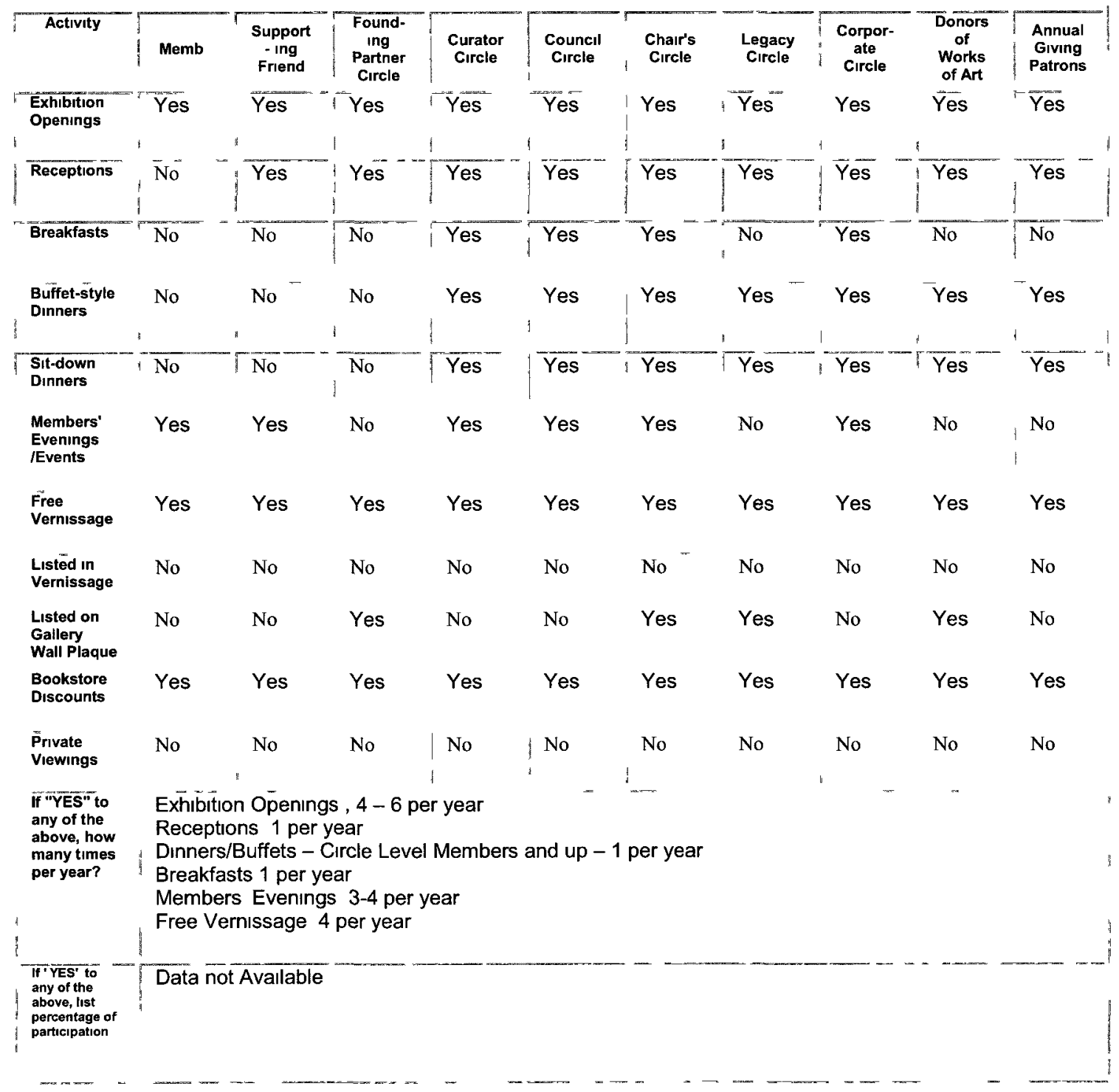




\section{Annex A - Survey Questionnaires}

\section{MFA Survey Questionnaire}

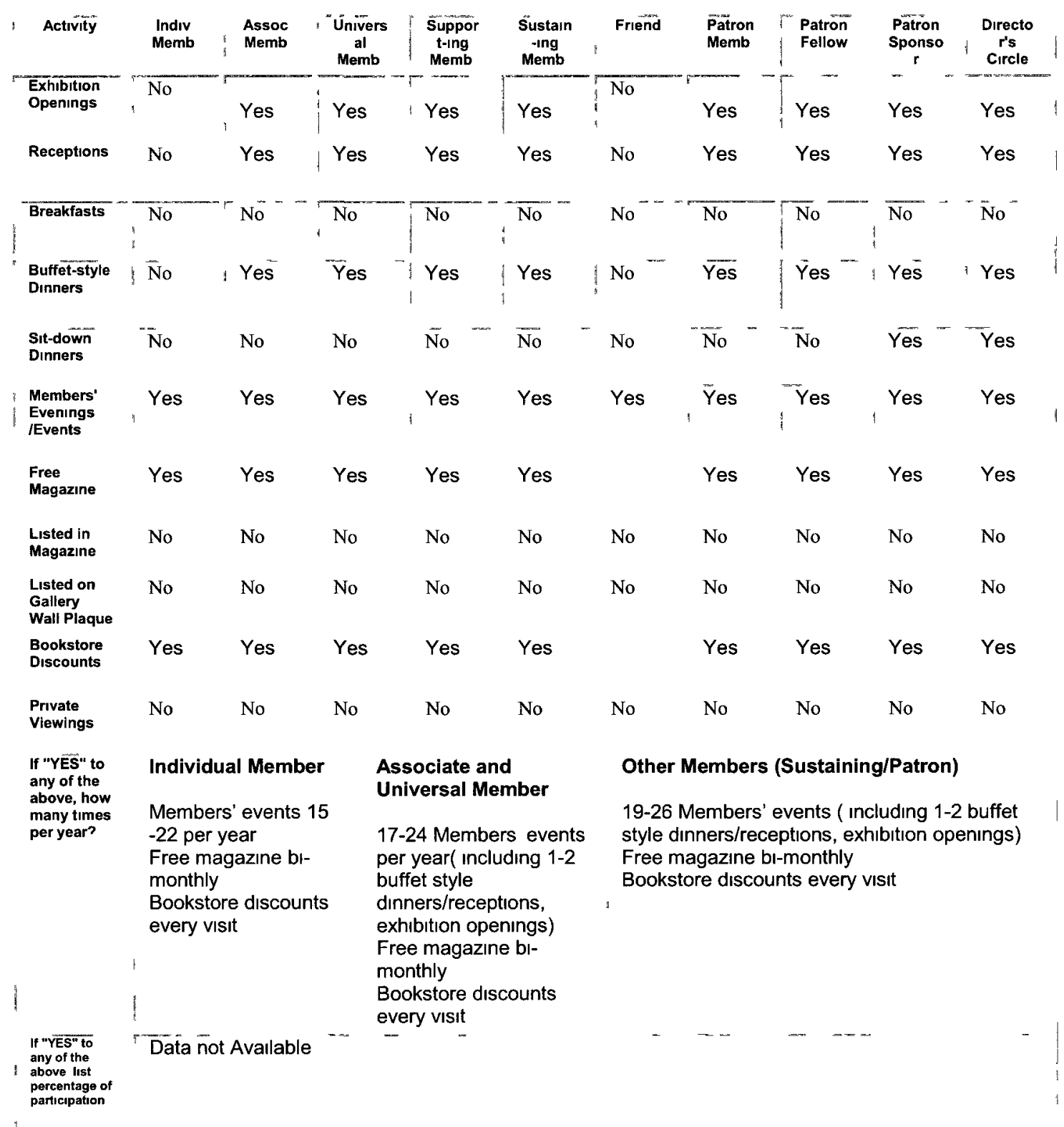




\section{Annex A - Survey Questionnaires}

\section{MoMA Survey Questionnaire}

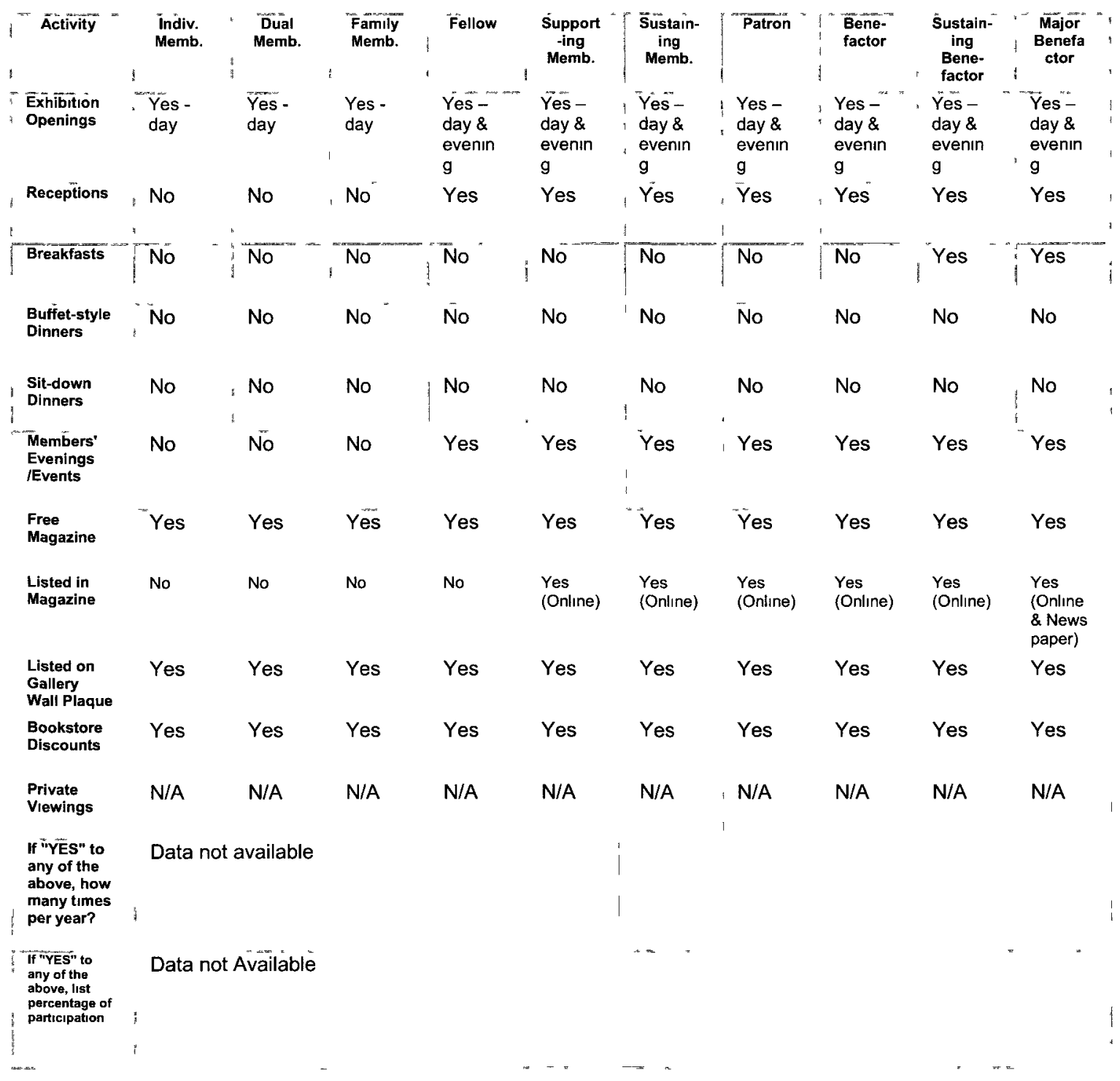




\section{Annex A - Survey Questionnaires}

\section{Tate Modern Survey Questionnaire*}

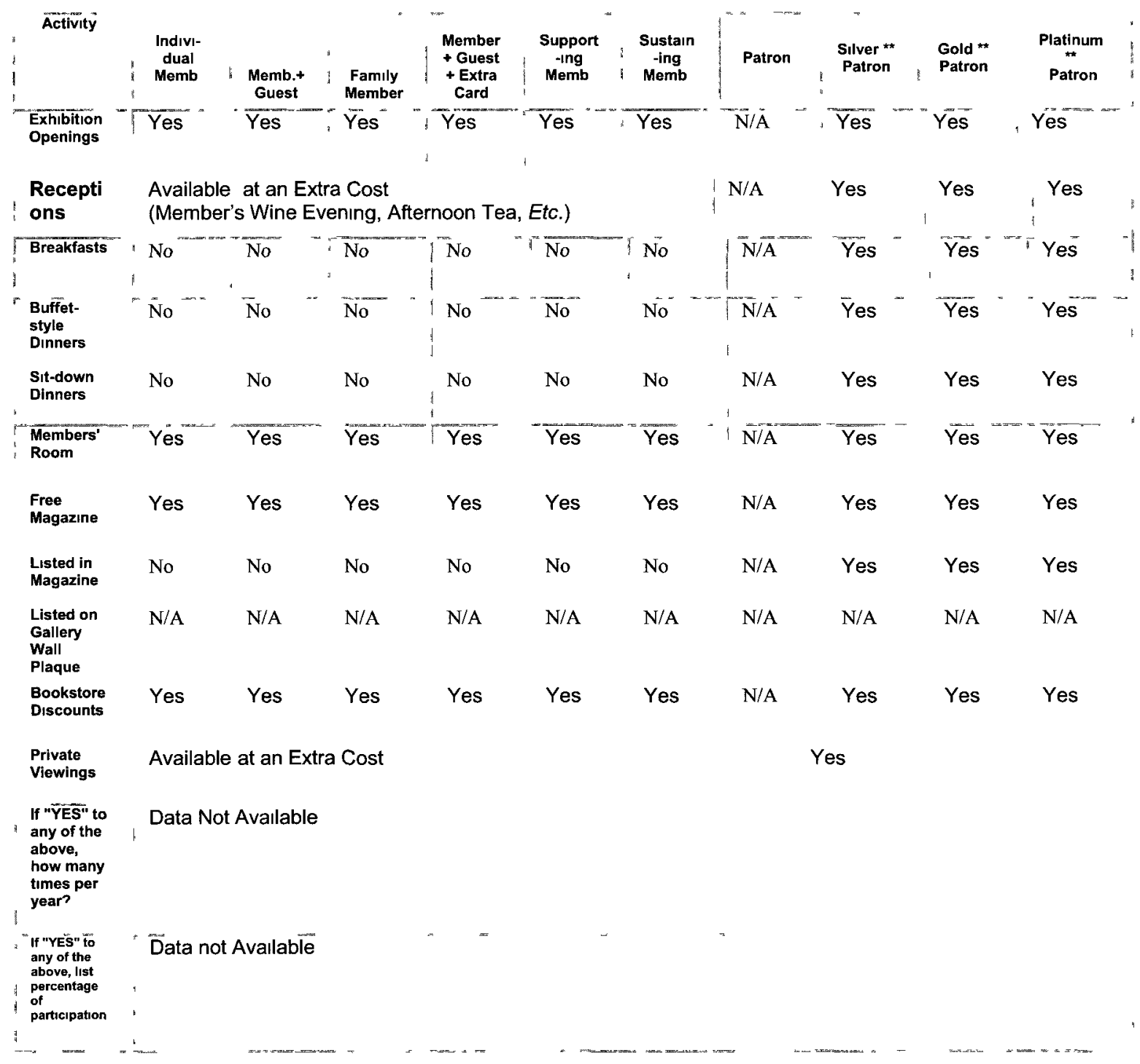

*Tate did not complete the questionnaire but referred me to its website. That is where this data comes from.

** Some extra events (exclusive) are available to Silver, Gold and Platinum patrons, such as:

- Artists Talks

- Installation Tours

- Behind the Scenes Tours

- Studio Visits

- Day Trips 


\section{Annex B - Site Maps}

\section{National Gallery of Canada Site Map}

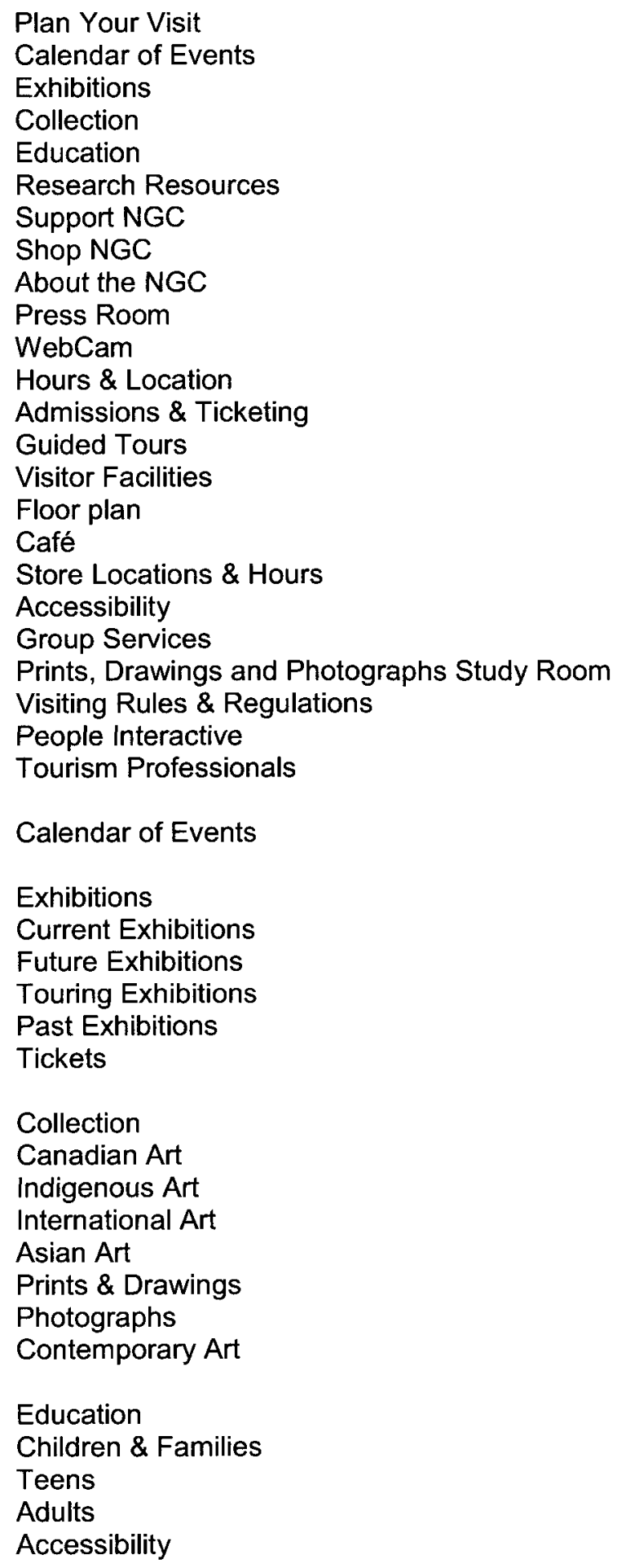




\section{Annex B - Site Maps \\ (NGC Continued)}

Research Resources

About the NGC

From the Director

Mission Statement

Corporate Governance

Career Opportunities

Student and Intern Opportunities

Governing Legislation

Online Communities

Press Room

Current Press Releases

NGC Press Release Archives

CMCP Press Release Archives

Media Centre

Password Request Form

Press Kits

Tickets

Host an Event

Provenance

Message from the Director

European and American Works of Art

Understanding Provenance Data

Image Reproduction

Search the Collection

Image Licensing

Top 10 Requested Images

Online Order Form

Rates and Fees

Frequently Asked Questions

Contact Us

Terms of Use 


\section{Annex B - Site Maps}

\section{Boston Museum of Fine Arts Site Map}

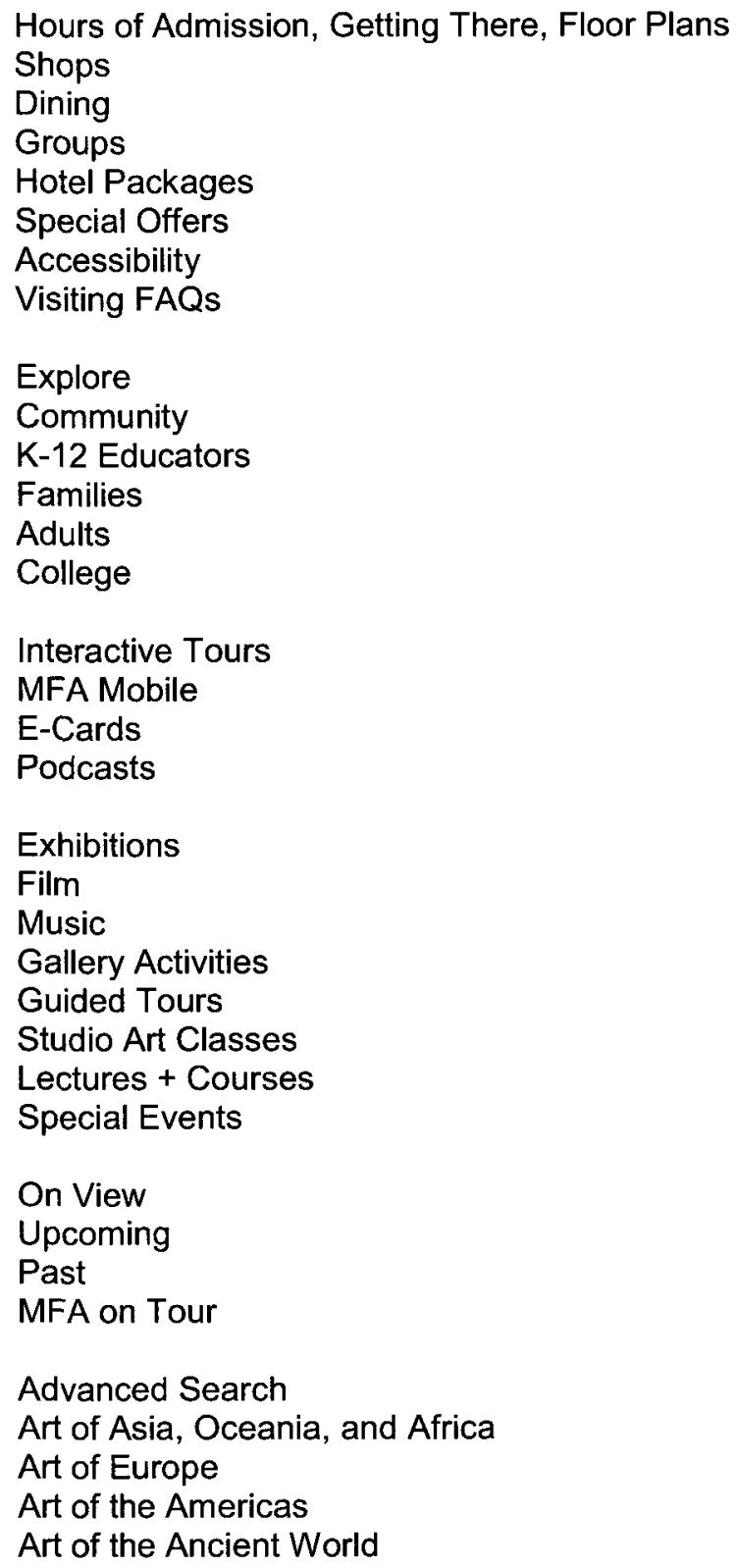




\section{Annex B - Site Maps}

(MFA Continued)

Contemporary Art

Musical Instruments

Prints, Drawings, and Photographs

Textile and Fashion Arts

Conservation and Collections Care

Recent Acquisitions

Resources

Building the New MFA

MFA Mail

Employment

Volunteer + Intern

MFA Images

Libraries + Archives

Mission Statement

FAQs

RSS/XML Feed

Special Exhibition Tickets

General Admission

Events and Classes

Membership

Activate Member Account

Membership

Museum Council

Patron Program

Friends Groups

Members' Room

Activate Member Account

Give

Building the New MFA

Endowment

Take Your Seat

MFA Fund

Planned Giving

Gifts of Art

Membership

Create Account

Subscribe to MFA Mail

Corporate Membership

Corporate Sponsorship

Corporate Philanthropy

Corporate Events

Press Releases 


\section{The Museum of Modern Art Site Map}

Home

Visit

Plan Your Visit

Hours and Admission

Admissions and Ticketing

Buy Tickets

Film Ticketing

Getting Here

Map and Directions

Parking

At the Museum

Floorplan and Visitor Guides

MoMA Audio

MoMA.guide Digital Kiosks

MoMA Audio

Visiting with a Family

Visitors with Special Needs

Groups

School Visits K-12

K-12 School Groups Reservation Form

Community Organizations

Community Group Reservation Form

Access Programs

Access Group Reservation Form

Adult Group Reservation Form

Offers and Discounts

Tips for Visiting

Restaurants and Cafés

MoMA Stores

Visitor Information in English

International/Visitor Information in French

International/Visitor Information in German International/Visitor Information in Italian International/Visitor Information in Spanish International/Visitor Information in Chinese International/Visitor information in Japanese International/Visitor Information in Korean Explore

Exhibitions

Upcoming

Past:

Touring Exhibitions 


\section{Annex B - Site Maps \\ (MoMA Continued)}

Films

Upcoming

Past:

The Collection

The Department of Architecture and Design

Architecture and Design in the Online Collection

Architecture and Design on View

Architecture and Design Highlights

Architecture and Design Recent Acquisitions

The Department of Drawings

Drawings in the Online Collection

Drawings on View

Drawings Highlights

Drawings Recent Acquisitions

The Department of Film

Film in the Online Collection

Film Highlights

Film Recent Acquisitions

Celeste Bartos International Film Study Center

The Department of Media and Performance Art

Media and Performance Art in the Online Collection

Media and Performance Art on View

Media and Performance Art Highlights

Media and Performance Art Recent Acquisitions

The Department of Painting and Sculpture

Painting and Sculpture in the Online Collection

Painting and Sculpture on View

Painting and Sculpture Highlights

Painting and Sculpture Recent Acquisitions

The Department of Photography

Photography in the Online Collection

Photography on View

Photography Highlights

Photography Recent Acquisitions

The Department of Prints and Illustrated Books

Prints and Illustrated Books in the Online Collection

Prints and Illustrated Books on View

Prints and Illustrated Books Highlights

Prints and Illustrated Books Recent Acquisitions

Browse the Online Collection 


\section{Annex B - Site Maps}

(MoMA Continued)

Find a selection of works

Browse Artists

Browse Art Terms

Image Permissions

Provenance Research Project

Conservation

Les Demoiselles d'Avignon: Conserving a Modern Masterpiece

Cézanne Pissarro: Seeing Through Paint

Unveiling Monet

Jackson Pollock: "No Chaos, Damn It": An Interview with Jim Coddington, Chief Conservator Matters in Media Art: Collaborating Toward the Care of Time-Based Media

Conservation FAQ

Publications

MoMA Multimedia (audio, video, and interactives)

MoMA Voices

Online Communities

Learn

Find a Program

Adult

Current MoMA Course Offerings

MoMA Courses Frequently Asked Questions

Members

Academic Community

Community Organizations

Families

$\mathrm{K}-12$ Educators

$\mathrm{K}-12$ School Groups

Teens

Visitors with Special Needs

Access School and Teacher Programs

Blind and Partially Sighted Visitors

Deaf and Hard of Hearing Visitors

Homebound Individuals

Individuals with Alzheimer's

The MoMA Alzheimer's Project

Special Events for Seniors

Visitors with Developmental or Learning Disabilities

Visitors with Limited Mobility

Planning a Group Visit

Access Programs Contact Information

Program Contact Information

Education Support

Program Acknowledgements

Research Resources

Library 


\section{Annex B - Site Maps}

(MoMA Continued)

\section{DADABASE}

Survey of Archives of Latino and Latin American Art Latin American Bibliography

Jasper Johns Bibliography

Jackson Pollock Bibliography

FAQs

Archives

Search Finding Aids

Contacting the Archives

Visiting the Archives

About the Archives

Holdings

Highlights

Exhibition History List

Selected Readings

Oral Histories

Photographic Archives

Study Centers

\section{Library FAQ}

DADABASE FAQ

Art Research FAQ

MoMA Research FAQ

Online Activities

International Program

Publications

Primary Documents: A Sourcebook for Eastern and Central European Art since the 1950s Listen, Here, Now! Argentine Art in the 1960s: Writings of the Avant-Garde

Modern Swedish Design: Three Founding Texts

Alfredo Boulton and his Contemporaries: Critical Dialogues in Venezuelan Art, 1912-1974

Museum Professional Workshops/Institutes

African Workshops

Latin American Workshops

Asia/Pacific Workshops

European Workshops

Public Programs

Caribbean Modernist Architecture Symposium

Circulating Exhibitions

Africa

Americas

Asia/Pacific

Europe

Support

Membership

Join Today 


\section{Annex B - Site Maps}

(MoMA Continued)

Renew Your Membership

Membership Categories

Gift Memberships

Members Programs

Support the Museum

Donate Online

Affiliate Groups

Annual Fund

Corporate Membership

Levels and Benefits

Corporate Member Employee Benefits

Corporate Entertaining

Corporate Entertaining Inquiry Form

Executive Courtesy Card Benefits

Corporate Member Roster

Enrolment Form

Education Support

Exhibition Support

P.S.1 Support

Special Events/Benefits

Ways of Giving

[Director's Letter]

Junior Associates Website

About MoMA

Mission Statement

From the Director

Museum History

Architectural Chronology

MoMA Builds

Nouvel Tower

Affiliation with P.S.1

Board of Trustees

Departments and Contacts

Jobs, Internships, and Volunteering

Jobs

Internships

Types of Internships

Eligibility, Deadlines, and How to Apply

High School Internships

Frequently Asked Questions

Contact Information

Volunteering

FAQ

About This Site 
Privacy and Security

Site Index

Help

E-Cards

E-News

Press

Junior Associates Website

Destination: Modern Art

Red Studio

Modern Teachers

Art Safari

PopRally

\title{
Tate Modern Site Map
}

\author{
Visiting Tate Modern \\ About \\ The Building \\ History \\ Facts \& Figures \\ Bankside \\ Community Garden \\ Transforming Tate Modern \\ Explore Tate Modern \\ Collection Displays \\ Tate Tracks \\ Exhibitions \\ Past Exhibitions \\ Current Exhibitions \\ Future Exhibitions \\ The Unilever Series \\ Level 2 Gallery \\ Events \& Education \\ Talks \& Discussions \\ Gallery Tours \& Groups \\ Symposia \\ Courses \& Workshops \\ Film \\ Music \& Performance \\ Raw Canvas \\ Schools \\ Community Groups \\ Multimedia Tour \\ Eating \& Drinking \\ Research \\ Tate Research \\ News \\ Research Centres \\ Research Projects \\ Tate Papers \\ Partnerships
}




\author{
Annex B - Site Maps \\ (Tate Modern Continued) \\ Research Posts \\ Research Services \\ Hyman Kreitman Research Centre \\ Library Collection \\ Library Catalogue \\ Archive Collection \\ Archive Catalogue \\ Prints and Drawings Rooms \\ Reproductions \\ Learn Online \\ Online Courses \\ Study Days Online \\ Value of Art \\ In Focus \\ i-Map \\ Kids \\ My Gallery \\ Games \\ Films \\ Tate Create \\ Adult Zone \\ Schools and Teachers \\ Schools Online \\ Tate Teachers \\ Schools Projects \\ Tate Tools \\ Web Quests \\ Young Tate \\ Events at Tate Britain \\ Events at Tate Modern \\ Events at Tate Liverpool \\ Events at Tate St Ives, Tate Channel, TateShots Blog, Podcasts
}




\section{Annex C - Web Images}

\section{Images from the Young Tate Website: Reaching Out to Teens}
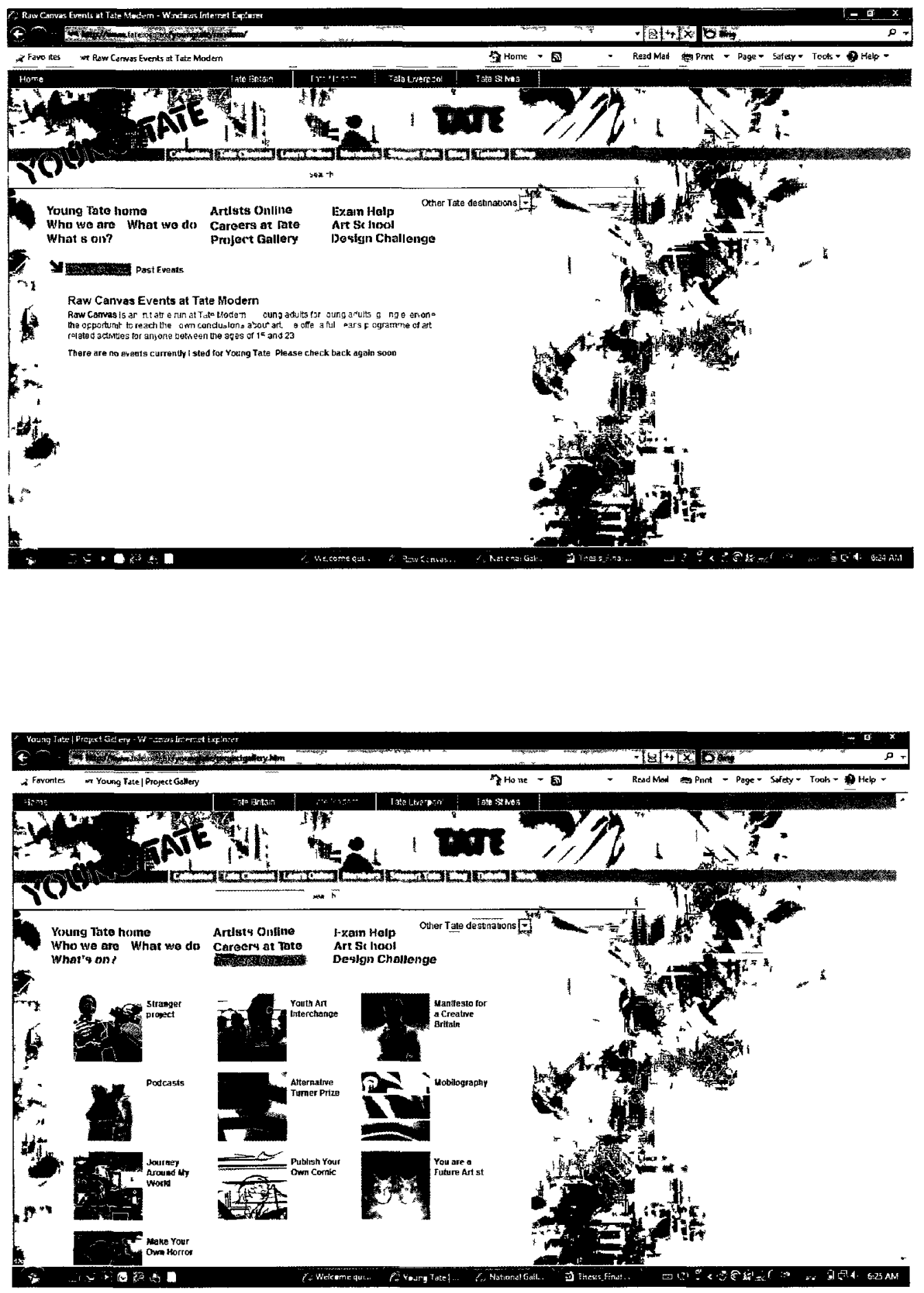


\section{Annex C - Web Images}

\section{Images from the Young Tate Website: Reaching Out to Teens}
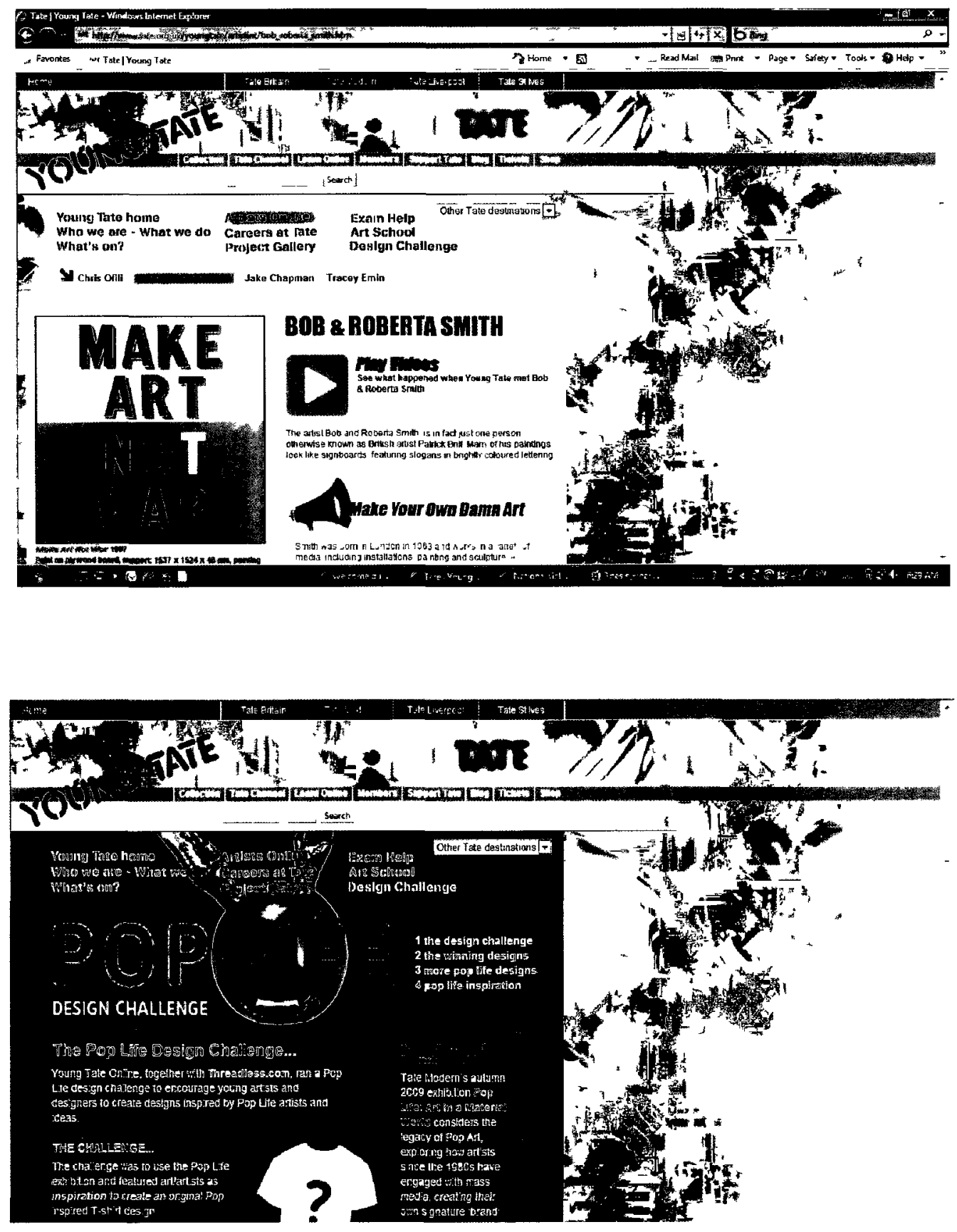


\section{Annex C - Web Images}

\section{Teen Programs at the MoMA}

While the MoMA does not have a Teen website, it does have a number of ongoing programs for teens, including "Free Teen Nights at the MoMA (Not yet scheduled):

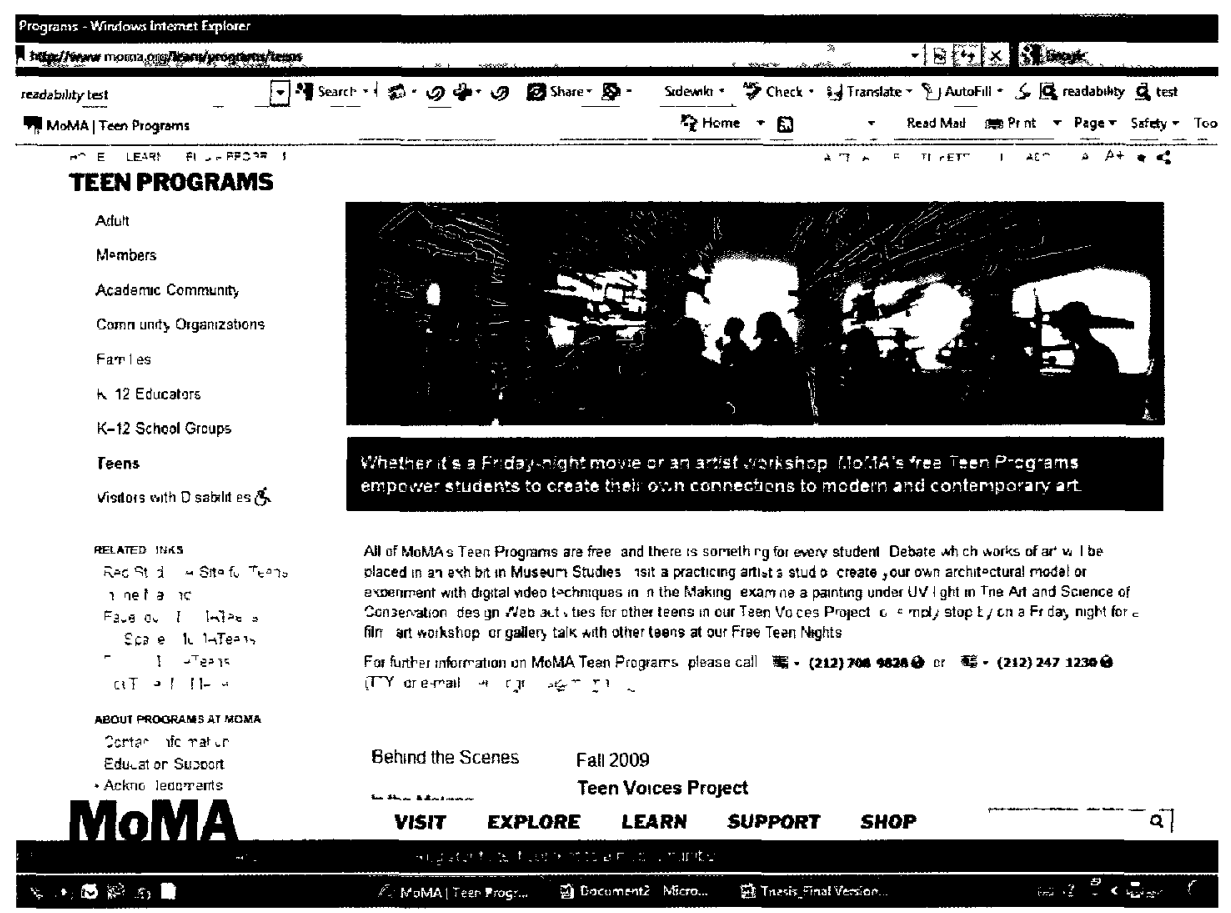




\section{Annex C - Web Images}

\section{Teens at the MFA: College}

The MFA has family programs as well as a separate program for local university/college students. It does not have a special website for teens.

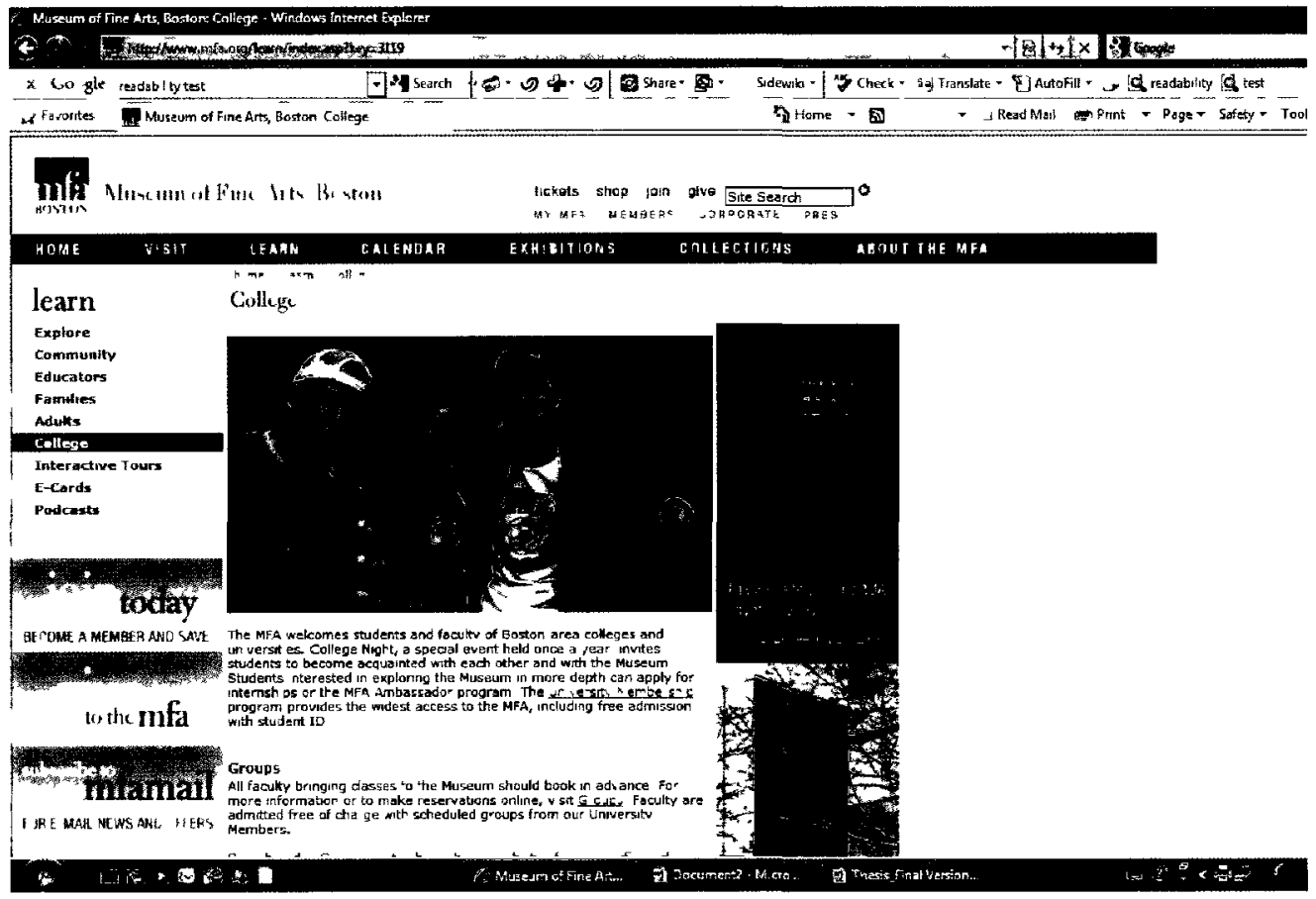




\section{Annex C - Web Images}

Teens at the NGC

The NGC has self-guided tours of the Collection for teens. It does not have a separate website.

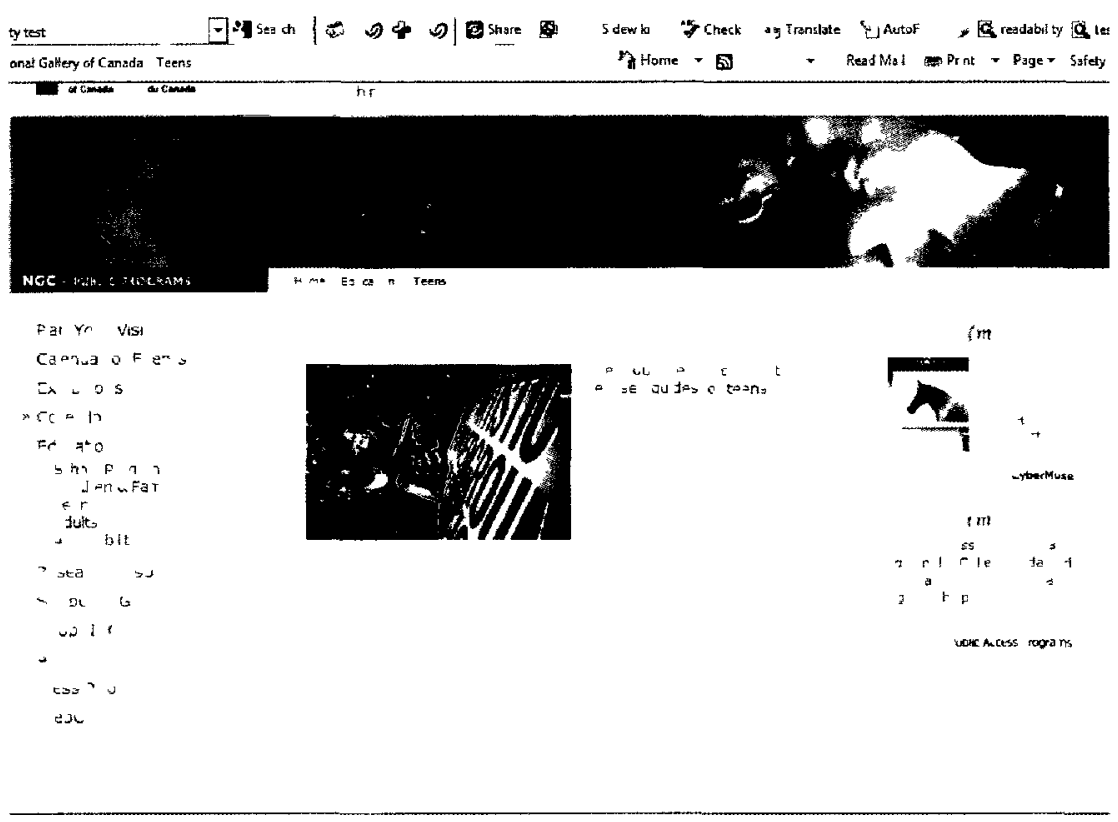

